\title{
Penha: de bairro rural a bairro paulistano Um estudo do processo de configuração do espaço penhense.
}

\author{
EDSON PENHA DE JESUS
}

Dissertação de Mestrado apresentada ao Programa de Pós-graduação em Geografia Humana do Departamento de Geografia da Faculdade de Filosofia, Letras e Ciências Humanas da Universidade de São Paulo, sob a orientação da Professora Doutora Margarida Maria de Andrade. 


\title{
Penha: de bairro rural a bairro paulistano Um estudo do processo de configuração do espaço penhense.
}

\author{
EDSON PENHA DE JESUS
}

Dissertação de Mestrado apresentada ao Programa de Pós-graduação em Geografia Humana do Departamento de Geografia da Faculdade de Filosofia, Letras e Ciências Humanas da Universidade de São Paulo, sob a orientação da Professora Doutora Margarida Maria de Andrade. 
Para: meus pais Doraci e Félix, minhas irmãs, Elisabete e Edna e minha companheira Ana Paula. 


\section{$\underline{\text { Agradecimentos }}$}

Um trabalho acadêmico nunca é resultado de uma ação inteiramente individual, resulta do acúmulo de aprendizagens coletivas e de trocas de experiências cultivadas no dia-a-dia do pesquisador, e, ao longo dos anos de desenvolvimento desta pesquisa, não foram poucos aqueles que, direta ou indiretamente, merecem aqui os meus mais sinceros agradecimentos.

No entanto, algumas pessoas e instituições foram decisivas para que eu chegasse até aqui e devem ser citadas com o devido destaque.

Em primeiro lugar, meus agradecimentos mais sinceros à Professora Margarida Maria de Andrade, não apenas pela valorosa e dedicada orientação, mas também pela suas críticas, correções, sugestões, paciência e, principalmente, pela amizade e por não deixar que as pedras no meio do caminho me fizessem desistir do objetivo final.

Ao Departamento de Geografia da Universidade de São Paulo e aos professores da casa, em especial às Professoras Odette Seabra e Léa Francescone. Também merecem meu agradecimento o Professor Murilo Marx da Faculdade de Arquitetura e Urbanismo da Universidade de São Paulo e a Professora Eneida Gonçalves de Macedo Haddad.

Aos funcionários do Arquivo do Estado de São Paulo, da Cúria Metropolitana, do Arquivo Histórico Municipal e da Biblioteca da Faculdade de Filosofia, Letras e Ciências Humanas da Universidade de São Paulo, todos eles viabilizando o acesso a livros e documentos indispensáveis para a realização deste trabalho.

Ao Francisco Folco do Memorial Penha de França, pela simpatia, atenção e contribuição.

Aos amigos e colegas dos colóquios sobre a obra de Henri Lefevbre, Adriano Botelho, Mônica Silveira Brito e principalmente Aluisio Wellichan Ramos.

Aos meus familiares e amigos, pelo carinho, incentivo e paciência.

Às funcionárias Jurema e Ana, da Secretaria de Pós-Graduação do Departamento de Geografia que sempre tiveram palavras amigas para os momentos difíceis.

Ficam também os meus mais sinceros agradecimentos aos moradores e exmoradores da Penha, cujas entrevistas foram fundamentais para a conclusão deste trabalho. 


\section{$\underline{\text { Resumo }}$}

O presente trabalho é um estudo sobre a configuração do espaço penhense a partir, sobretudo, da consideração de práticas sociais que marcaram a história dessa porção da cidade de São Paulo.

O entendimento desta problemática passa pela análise das continuidades e descontinuidades históricas e das relações de vizinhança, enquanto referência de vida de bairro, que deram à Penha certa originalidade em relação aos demais bairros de São Paulo.

O período abrangido no estudo se estende desde a formação do patrimônio religioso e o estabelecimento da freguesia de Nossa Senhora da Penha, até a metropolização, momento de grande ruptura marcada pelo fim da vida de bairro na localidade.

O estudo destaca três momentos: a constituição da Penha enquanto bairro rural; a constituição da Penha enquanto subúrbio; e a constituição da Penha enquanto bairro da cidade de São Paulo.

A compreensão das transformações espaciais na Penha e de todo o conjunto acima descrito só é possível se realizam se tivermos em mente a cidade e seus processos (industrialização e urbanização) enquanto instauradores do modo de vida urbano.

Com isso acreditamos também estar contribuindo para a compreensão do desenvolvimento urbano da cidade de São Paulo.

Palavras-chaves: bairro rural, subúrbio, bairro, vida de bairro, urbanização, Bairro da Penha. 


\section{$\underline{\text { Abstract }}$}

The present work is a study about the configuration of the penhense space from, over all, the consideration of social practices that marked the history of this portion of the São Paulo city.

The agreement of this problematic pass through analysis of the historical continuities and discontinuities and the neighborhood relations, while reference of neighborhood life, that had given to Penha some originality in relation to others neighborhood of São Paulo.

The period enclosed on the study extends since the formation of the religious patrimony, establishment of the Nossa Senhora da Penha parish, until the metropolization, moment of large rupture marked for the end of the neighborhood life in the locality.

The study point out three moments: the constitution of Penha while rural neighborhood; the constitution of Penha while suburb; and the constitution of Penha while neighborhood of the São Paulo city.

The comprehension of the space transformations on the neighborhood of Penha and

all set described above have only accomplished if we have in mind the city and its processes (industrialization and urbanization) while founders of the urban way of living.

With this we also believe to be contributing for the understanding of the urban development of the city of São Paulo.

Keywords: rural neighborhood, suburb, neighborhood, neighborhood life, urbanization, neighborhood of Penha. 


\section{Penha: de bairro rural a bairro paulistano Um estudo do processo de configuração do espaço Penhense.}

\section{ÍNDICE}

INTRODUÇÃO $\quad 09$

A escolha do tema $\quad 10$

$\begin{array}{ll}\text { Um estudo de bairro } & 12\end{array}$

$\begin{array}{ll}\text { As continuidades e descontinuidades históricas na Penha } & 17\end{array}$

CAPÍTULO 1: O bairro rural de Nossa Senhora da Penha 27

1.1 Considerações iniciais $\quad 28$

1.2 Uma capela, uma sesmaria: nasce o aglomerado 30

1.3 Penha: um bairro rural $\quad 38$

1.4 Algumas considerações sobre o catolicismo na organização do espaço $\begin{array}{ll}\text { brasileiro } & 49\end{array}$

1.5 A procissão de Nossa senhora da Penha: fator de aproximação do bairro rural da Penha com a capital.

1.6 A questão da terra enquanto fator de enfraquecimento da realidade rural na Penha

CAPÍTULO 2: Penha: um subúrbio paulistano

2.1 Considerações iniciais $\quad 92$

2.2 A chegada da ferrovia $\quad 97$

2.3 A Penha como subúrbio próximo $\quad 111$

2.4 A valorização do espaço e o avanço da urbanização 121

2.5 Aspectos socioculturais do subúrbio penhense até a década de 1930

CAPÍTULO 3: Penha: um bairro paulistano 184

3.1 Considerações iniciais 185

3.2 A Penha na década de 1940: anúncio da metropolização e do fim da vida $\begin{array}{ll}\text { de bairro } & 187\end{array}$

$\begin{array}{ll}3.3 \mathrm{O} \text { fim da vida de bairro } & 205\end{array}$

CONSIDERAÇÕES FINAIS

REFERÊNCIAS BIBLIOGRÁFICAS $\quad 231$ 
Introdução 


\section{A escolha do tema}

Foi do contato quase que diário com a porção central do bairro da Penha que nasceu a idéia de desenvolver este trabalho. Primeiro, a curiosidade depois o projeto de pesquisa. Um projeto de investigação que buscasse responder a uma pergunta inicial: como o bairro da Penha foi espacialmente organizado ao longo de sua história e da história da cidade de São Paulo?

Com as leituras e as pesquisas sobre a cidade de São Paulo e sobre o bairro da Penha constatou-se o quanto a história da estruturação urbana da localidade se encontra intrinsecamente atrelada ao desenvolvimento da cidade de São Paulo. Porém, essa articulação apresentou-se em movimento e diferenciada ao longo do tempo. Desta forma, uma segunda pergunta surgiu: como será que se processaram as relações entre o bairro estudado e a cidade de São Paulo?

Destas duas perguntas iniciais surgiram os primeiros esboços da investigação. Daí, novos questionamentos se apresentaram. Entre eles, como havia se efetuado a passagem do rural para o urbano na Penha e até que ponto a chegada da ferrovia havia contribuído para a aceleração da inflexão do rural pelo urbano na localidade? E ainda, qual foi o papel das continuidades históricas, no caso a Igreja Católica e a propriedade fundiária, no processo de urbanização da Penha? E outra, quais aspectos da prática social permitiriam identificar a Penha, por hipótese, como bairro rural, como subúrbio e como bairro paulistano?

A escolha do bairro como objeto de investigação, não pode ser confundida como uma mera escolha de caráter físico-material. Segundo Aluísio, ao estudar o bairro paulistano da Água Branca,

[...] a opção pelo estudo do bairro nos leva, sem dúvida, a maior complexidade do que a simples escolha de uma área, demarcada por algum critério físico-material. Ao escolhermos o bairro como objeto de análise, fazemos uma opção pelo estudo do espaço social, o que, por conseguinte, inclui o estudo da cidade, enquanto totalidade. ${ }^{1}$

Assim, para o estudo do bairro da Penha, os mesmos propósitos se fazem necessários: grande atenção para que o resultado da análise dos dados coletados não acabe perdendo a cidade como referência ou, em oposição, deixando de valorizar as especificidades locais.

\footnotetext{
${ }^{1}$. RAMOS, Aluísio W. Fragmentação do espaço na cidade de São Paulo: espacialidades diversas do bairro da Água Branca. Dissertação de Mestrado, FFLCH, USP - Departamento de Geografia, 2001, p.9.
} 
Conforme Queiroz, “todo estudo deve, pois, considerar os fenômenos de um duplo ponto de vista: o de sua posição e composição, de seus condicionamentos, de suas relações, o de seu movimento, de suas transformações, de seu aparecimento e desaparecimento.” Portanto, o movimento é fruto das contradições internas que se alocam na sociedade no decorrer de sua história. ${ }^{2}$

O espaço social está longe de qualquer possibilidade de se apresentar neutro e passivo diante dos agentes e relações sociais que se apresentam em conflitos de interesses e em luta social. ${ }^{3}$ Segundo Souza, trata-se

[...] de ação recíproca que se estabelece entre as relações sociais e o Espaço produzido nos marcos de uma organização social determinada. Este, uma vez produzido dessa ou daquela maneira, passa automaticamente a atuar como um dos referenciais para a vida e os projetos dos seus produtores, homens em sociedade. ${ }^{4}$

O espaço, enquanto local do desenrolar da vida social com suas contradições e como fruto de uma apropriação pelas práticas sociais, é concebido por Lefebvre como espaço concreto, do habitar e do vivido. ${ }^{5}$ E é no nível do vivido que o bairro se realiza.

Da qualidade das relações sociais que se estabelecem no espaço é que se “articulam os fios que ligam e que separam os indivíduos". ${ }^{6}$ Tais relações, estabelecidas pela proximidade (do compadrio, da vizinhança, da parentela) permitem as trocas de experiências, produzem profundos enraizamentos entre os cidadãos, ganham realidade e traduzem-se como vida de bairro. ${ }^{7}$

2. QUEIROZ, Maria I. P. Cultura, sociedade rural, sociedade urbana no Brasil, São Paulo: Editora Universidade de São Paulo, 1978, p. 270.

${ }^{3}$. SOUZA, Marcelo J. L. de. O bairro contemporâneo: ensaio de abordagem política. In: Revista Brasileira de Geografia, no 51, Rio de Janeiro, IBGE, 1989, p.140. 'O Espaço não é um palco 'neutro' em situação alguma, e sua materialidade - como, de resto, qualquer materialidade - exerce um certo condicionamento sobre os atores sociais, configurando uma dialética; não obstante esse condicionamento relativo varia, em natureza e intensidade, conforme o tipo de relação social."

4. Ibidem, p.140. Souza afirma que suas referências teóricas vinculam-se à dialética sócio-espacial desenvolvidas nos estudos de Henri Lefebvre e Edward Soja.

5. LEFEBVRE, Henri. A Revolução Urbana, tradução de Sérgio Martins, Belo Horizonte: Ed. da UFMG, 1999, p.166. "O espaço concreto é o do habitar: dos gestos e percursos, corpo e memória, símbolos e sentidos, difícil maturação do imaturo-prematuro (do 'ser humano'), contradições e conflitos entre desejos e necessidades, etc."

6. SEABRA, Odette, C. L. Urbanização e fragmentação: Cotidiano e vida de bairro na metamorfose da cidade em metrópole, a partir das transformações do bairro do Limão. Tese de livre-docência, FFLCH, USP - Departamento de Geografia, 2003, p.2.

7. SEABRA, Odette, C. L. Urbanização: bairro e vida de bairro. Travessia: revista do migrante. São Paulo, ano XIII, n.38, set./dez. de 2000, publicação do CEM, p.12. 


\section{Um estudo de bairro}

A priori, o bairro não pode ser visto como uma unidade territorial rígida, definida política e administrativamente e com caráter físico-material delimitado a partir de estratégias governamentais ou de planejadores urbanos. Conceber o bairro desta forma seria aceitá-lo como espaço abstrato (geométrico, vazio, ideal) e negá-lo como espaço de potencialização do sentimento coletivo (que legitima a vida de bairro). Como o corte adotado para a pesquisa aqui proposta é o bairro, enquanto espaço de realização do vivido, é neste contexto que buscamos sua definição. ${ }^{8}$

Segundo Mendes, o bairro apresenta-se como uma localidade que possui “características muito próprias, que com o passar do tempo, se reforçam e acabam por individualizá-lo de maneira inconfundível, tanto para os que nele habitam como no conceito geral da população". 9

A partir das idéias analisadas nos parágrafos acima, podemos procurar entender o bairro como resultado da vida prática daqueles que nele habitam e como fruto do movimento dos elementos concretos que se associam aos contextos prático-sociais derivados das atividades econômicas, culturais, religiosas. Essa individualidade se constrói e se consolida ao longo do tempo histórico e se efetua repleta de elementos, objetos, produtos e relações que se transformam em referências que nos levam a crer que não existem bairros semelhantes.

Segundo Candido, em suas análises sobre bairro rural,

o conceito de bairro começa pela base territorial, essencial à sua configuração [...] mas além de determinado território, o bairro se caracteriza por um elemento, o sentimento de localidade existente nos seus moradores, e cuja formação depende não apenas da posição geográfica, mas também do intercâmbio entre as famílias e as pessoas, vestindo por assim dizer um esqueleto topográfico. ${ }^{10}$

Para Pierre George, o bairro apresenta-se como unidade de vida social. Segundo o autor, "a unidade de base da vida urbana é o bairro: na origem, com freqüência, uma antiga unidade religiosa ou uma paróquia ainda em atividade ou um conjunto funcional como 'bairro' do mercado, a zona de agrupamento dos artesãos de uma ou várias profissões, o bairro dos conventos, etc." ${ }^{11}$ Como unidade de vida social, o bairro

8. RAMOS, A. W., op. cit., 2001, p.10, apoiado em LEFEBVRE, H., A Revolução Urbana. Belo Horizonte: Editora da UFMG, 1999, p.166.

9 . MENDES, Renato de S. Os Bairros da Zona Norte e os Bairros Orientais. In: Azevedo, A. (org.). A cidade de São Paulo: (estudos de Geografia Urbana). São Paulo: Cia. Ed. Nacional, 3 vols, 1958. p. 185.

${ }^{10}$. CANDIDO, Antonio. Os parceiros do Rio Bonito: estudo sobre o caipira paulista e a transformação dos seus meios de vida. $8^{\text {a }}$ ed. São Paulo: Duas cidades, 1998, p.64-65.

${ }^{11}$. GEORGE, Pierre. Geografia Urbana. São Paulo: DIFEL, 1983, p.76. "O morador refere-se ao seu bairro, quando quer situar-se na cidade; tem a impressão de ultrapassar um limite quando vai a um outro 
proporciona a seu morador a consciência de ser parte de algo e que esse algo vai além do bairro, alcança a cidade, alcança a vida pública e se organiza como representação popular. $^{12}$

Lefebvre, ao analisar o bairro na Europa Ocidental, também o identifica como uma unidade de vida urbana, porém avança na análise chamando a atenção para a existência de uma "ideologia de bairro". ${ }^{13}$ Segundo Lefebvre, a "ideologia de bairro" se sustenta na apologia da paróquia e da vida paroquial. O bairro se estruturou em torno da paróquia, isto é, se organizou em torno da existência religiosa que também se apresentava como existência civil e política (os registros de nascimento, de casamento e de óbito eram de responsabilidade da Igreja) ${ }^{14}$.

Com o tempo, a paróquia começa a perder seu papel estruturador do bairro, papel este exercido, cada vez mais, pelo Estado

Para Lefebvre, o bairro não intervém mais na proclamação dos valores dominantes, limita-se “ao nível das relações imediatas e diretas, interpessoais, dependentes da psicossociologia ou da sociologia, desenrolando-se à sombra das instituições”. ${ }^{15}$ Assim, o entendimento do bairro deve partir da cidade como totalidade, afinal "o bairro é uma forma de organização concreta do espaço e do tempo da cidade". 16

Para Ramos, o bairro

[...] não existe enquanto unidade isolada e autônoma [...] o bairro é uma unidade, porém, como propõe Lefebvre, uma 'unidade sociológica relativa', que só pode ser pensada tendo-se em vista a cidade como totalidade, não é, pois, a base da vida urbana. Ao contrário, a base da vida urbana para Lefebvre é o centro. É a noção de centralidade que constrói, que torna possível a cidade e seus bairros. Por isso, a centralidade é a essência da cidade. ${ }^{17}$

Assim, segundo Lefebvre, o único procedimento científico possível para o entendimento do bairro,

[...] para defini-lo, determinando seus limites e seu grau de realidade, é o que se baseia na cidade como totalidade e não como conjunto de elementos ou coleção de aspectos (e em conseqüência na sociedade como um todo superior às formas, às estruturas e as funções) que engloba. Sejam quais forem as dificuldades de

bairro. A organização administrativa, geralmente, codificou estes dados empíricos e emprestou-lhe uma forma mais rígida. É com base no bairro que se desenvolve a vida pública, que se organiza a representação popular. Finalmente, e não é o menos importante, o bairro tem um nome, que lhe confere uma personalidade dentro da cidade."

${ }^{12}$. Ibidem.

13. LEFEBVRE. Henri. Barrio y vida de barrio. In: De lo rural a lo urbano. Barcelona: Ediciones Península, 1975, p.195-197.

${ }^{14}$. Ibidem, p.197.

${ }^{15}$. Ibidem, p.200.

${ }^{16}$. Ibidem.

${ }^{17}$. RAMOS, A. W., op. cit., 2001, p.11. Cf. LEFBVRE, H. op. cit., 1975, p.200-201. 
acesso à totalidade e de apreensão do global, este procedimento é o único aceitável. ${ }^{18}$

\section{Para Milton Santos,}

[...] o todo somente pode ser conhecido através do conhecimento das partes e as partes somente podem ser conhecidas através do conhecimento do todo, essas duas verdades são, porém, parciais. Para alcançar a verdade total, é necessário reconhecer o movimento conjunto do todo e das partes, através do processo de totalização. ${ }^{19}$

Em cada momento da totalidade desenvolve-se uma realidade concreta e esta ao mesmo tempo apresenta-se como processo de transformação. O ciclo nunca se encerra. O bairro aparece como totalidade e como parcela de uma totalidade maior, a cidade. Nele, estruturas locais e externas irão se fundir e formar o espaço social. ${ }^{20}$

Os bairros apresentam diferentes realidades ao longo dos diferentes momentos de sua história e da história da cidade à qual ele se encontra inserido. Tal conteúdo, no estudo do bairro, possibilita a identificação de diferentes níveis de realidade.

Segundo Lefebvre, para que as investigações sobre o bairro sejam precisas, é necessário estabelecer uma certa “tipologia dos bairros” que, após análises dos equipamentos estabelecidos, permitisse classificar os bairros em diferentes tipos (os que se mantém, os que se consolidam, os que desaparecem). O autor ainda afirma que para esta classificação se exige "o estudo das imbricações e relações internas e externas entre os bairros e o que os rodeia”. Porém, alerta Lefebvre que a definição de tipologia não é suficiente e que a investigação deve se preocupar com o estudo das tendências (tendência à consolidação ou ao desaparecimento do bairro, esta última sendo mais aceita pelo autor ao considerar a urbanização contemporânea; tendência segundo a cidade cresça ou se estanque, tendência segundo o tipo de crescimento da cidade entre outras). No entanto, "na maioria das cidades, a investigação da tendência se insere dentro do estudo da região, do território que a rodeia e da planificação deste território.”21

Como resultado da vida prática, podemos dizer que o bairro é dotado de certa funcionalidade e apresenta-se como unidade individualizada dentro da cidade.

Sobre essa idéia, podemos citar Monbeig:

18. LEFEBVRE, H., op. cit., 1975, p.199.

19. SANTOS, Milton. A natureza do espaço, técnica e tempo - razão e emoção. São Paulo: Ed. Hucitec. $3^{\circ}$ ed., 1999, p. 96.

${ }^{20}$. Cf. LEFEBVRE, H., op. cit., 1975, p.196.

${ }^{21}$. Ibidem, p.203. 
[...] uma cidade é um conjunto de bairros, dos quais cada um tem sua fisionomia, que é resultado de seu papel, de seus habitantes, de sua idade, e, todos mais ou menos bem integrados em um todo, formam a cidade. Um bairro urbano é algo diferente de um fenômeno social, com localização de uma base ou de uma categoria de trabalhadores: um bairro urbano tem feição que só a ele pertence, uma vida particular freqüentemente bem desenvolvida; tem sua alma. Mas, tem também suas razões de ser que a topografia e a história podem explicar. ${ }^{22}$

Essas características muito próprias e individuais nos remetem a Pierre George e sua afirmação de que "o bairro tem um nome que lhe confere uma personalidade dentro da cidade."23

Para Ramos, essa personalidade a que Pierre George se refere é equivalente à noção de identidade (localidade). A seu ver:

a identidade de um determinado local, é, pois uma identidade sócio-espacial [...] De um lado, a identidade de um bairro está, em nosso entender, largamente vinculada à função econômica predominante, a qual é historicamente determinada [...] De outro lado a identidade de um bairro é, pois, um termo que nos remete a uma relação inter-espacial também, isso porque a identidade de um determinado bairro está necessariamente vinculada à cidade da qual faz parte. ${ }^{24}$

Tal idéia também é compartilhada por Seabra:

o bairro apareceu, no processo de urbanização, como uma entidade sociocultural muito diversa, portadora de uma identidade que lhe ia sendo atribuída de fora para dentro, ou seja, do contexto da cidade. O que só era possível porque o bairro se integrava aos processos gerais da cidade, que paulatinamente moldavam um modo de vida urbano. ${ }^{25}$

Segundo Lefebvre,

[...] a totalidade não deve fazer esquecer que a parte e o elemento têm também uma existência diferenciada. Só o pensamento animado pelo método dialético permite, segundo parece, captar esta interação específica das partes no todo. Seria um erro subestimar o bairro, que sabemos é um todo no todo, contudo, na cidade que conhecemos o bairro só existe em função de uma certa história. ${ }^{26}$

Portanto o bairro, com os atributos de sua história, apresenta-se como espaço de destaque para o entendimento das metamorfoses da cidade em metrópole.

O entendimento do espaço penhense passa pelo entendimento das transformações que aconteceram e acontecem na cidade de São Paulo. Transformações que podem ser examinadas com base na relação entre urbanização e industrialização.

Na pesquisa sobre a Penha, assim como na pesquisa que Ramos desenvolveu sobre a Água Branca, o processo de urbanização deve ser entendido "como um processo de transformação da cidade e de generalização do modo de vida urbano" ${ }^{27}$, nos mesmos termos discutidos por Seabra em seu estudo sobre o bairro do Limão. Para a autora, a

22. MONBEIG, Pierre. O estudo geográfico das cidades. In: Boletim Geográfico, ano I, $\mathrm{n}^{\circ}$ 7, Conselho Nacional de Geografia/IBGE, outubro, 1943, p.18.

23. GEORGE, P., op. cit., 1983, p.76.

${ }^{24}$. RAMOS, A. W., op. cit., 2001, p.15.

25. SEABRA, O. C. L., op. cit., 2003, p. 1-2.

${ }^{26}$. LEFEBVRE. Henri, La vida social em la ciudad. In: De lo rural a lo urbano. Barcelona: Ediciones Península, 1975, p.142.

${ }^{27}$. RAMOS, A. W., op. cit., 2001, p.16-17. 
urbanização e toda sua força rentista avassaladora (que dilacera, que segrega, que exclui, que violenta) se fez presente e se apresenta como força motriz que impulsiona as transformações da e na cidade e seus bairros, assim como na forma de viver dos moradores. $^{28}$

Uma vez que o controle territorial passa para as mãos dos agentes do capital, os modos de vida anteriores (rural e pré-industrial) submetem-se ao processo de urbanização, porém os resíduos destes modos anteriores ainda persistem no novo espaço que se consolida. Assim, as análises do espaço urbano somente se apresentam possíveis se levarmos em conta as relações sócio-espaciais e suas transformações no tempo. Daí que, para Ramos, o bairro enquanto "uma categoria sócio-espacial, [...] inclui diversas espacialidades/temporalidades/sociabilidades que estão sobrepostas”29

A configuração sócio-espacial da Penha, somente pode ser compreendida a partir da história local ocorrendo no mesmo compasso que a história da cidade. Isto nada mais é que parte de um movimento maior, o das relações históricas, políticas e socioeconômicas da sociedade brasileira. ${ }^{30}$

\section{As continuidades e descontinuidades históricas na Penha}

"A cidade e o urbano não podem ser compreendidos sem as instituições oriundas das relações de classe e de propriedade. Ela mesma, a cidade, obra e ato perpétuos, dá lugar a instituições específicas: municipais. As instituições mais gerais, as que dependem do Estado, da realidade e da ideologia dominante, têm sua sede na cidade política, militar, religiosa. Elas aí coexistem com as instituições propriamente urbanas, administrativas, culturais. Donde certas continuidades notáveis através das mudanças da sociedade.” (Henri Lefebvre - 1991) ${ }^{31}$

Segundo Seabra, na busca da compreensão das metamorfoses da cidade encontramos continuidades que atravessam tempos sociais e históricos,

[...] tais continuidades mostram-se essenciais, desde que se observe que, através da cidade, que era centro da vida civil e política, foram sendo instaurados os processos modernizadores, com a formação dos circuitos capitalistas, que rapidamente alcançariam os modos de vida, ali onde a religiosidade e a religião se aninham, para circunscrevê-los como processos totais. Trata-se dos Institutos Jurídicos da propriedade territorial e da Religião, que atravessaram, quase incólumes, tempos sociais e históricos da cidade. A coerência, fictícia e real, do processo de modernização, sob o primado da lógica capitalista, seguiu impondo

${ }^{28}$. Cf. SEABRA, O. C. L., op. cit., 2003, p.7.

29. RAMOS, A. W., op. cit., 2001, p.19.

30 . Ibidem, p.19-20.

31 . LEFEBVRE, Henri. O Direito à Cidade. São Paulo: Editora Moraes, 1991, p.53. 
cesuras no plano da vida imediata, no vivido, instaurando um processo que teve originalmente a cidade histórica como teatro. Logo o urbano como modo de vida tem sua gênese na cidade histórica. É o social se constituindo onde cada indivíduo, cada trabalho, formando-se como parte de um todo, perde-se no horizonte propriamente individual porque se torna abstrato. ${ }^{32}$

Do mesmo modo, na Penha a propriedade fundiária e a Igreja, têm papel essencial, atuando ininterruptamente na configuração do espaço.

O entendimento da configuração do espaço na Penha pede a consideração do antigo regime português das sesmarias (regime de concessão de terras). Com a promulgação da Lei de Terras de 1850, em meio a várias contradições e conflitos econômicos e sociais, as terras passaram a ser transformadas em propriedades privadas. Desta forma, a terra se transformou em mercadoria e em pouco tempo deu vazão ao aparecimento de inúmeros loteamentos que transformaram as relações sócio-culturais na região penhense. Analisaremos esse processo com maior detalhamento mais adiante.

A Penha, como veremos, não sofreu de imediato todos os dissabores do processo especulativo imobiliário. A maioria das chácaras produtoras de hortifrutigranjeiros que existiam na região da Penha ainda vai se manter até meados da década de 1920. Porém, com o estabelecimento da linha férrea Central do Brasil na década de 1870, como aconteceu em toda a cidade de São Paulo, o processo de valorização da terra começou a se intensificar levando à substituição do rural pelo urbano.

Assim, temos a ferrovia como mais um dos agentes transformadores do espaço paulistano. ${ }^{33}$ Segundo Andrade, a ferrovia e seu complexo arquitetônico, além de valorizar as terras baixas próximas às várzeas e torná-las possíveis para o uso, principalmente pela indústria, também favoreceu a expansão do uso residencial para locais cada vez mais distantes do centro da cidade. Importante ressaltar que tais mudanças corresponderam aos processos globais da economia e da sociedade paulistana da época e contribuíram para a efetiva diferenciação dos espaços na cidade. ${ }^{34}$

A chegada da ferrovia e a ampliação do processo de especulação imobiliária apresentaram-se como fatores de grande significância para a compreensão da passagem

32 . SEABRA, O. C. L., op. cit., 2003, p.13.

33. DUARTE, C. R., op. cit, 2001, p.24. Segundo Duarte, "a chegada do trem no bairro converge com mudanças importantes na cidade como um todo. Um conjunto de fatores transforma-a: a industrialização incipiente, a grande entrada de imigrantes, a urbanização, o loteamento de terras, a demanda de materiais para construção etc. A cidade se moderniza, no sentido da acumulação do capital. É isso que explica a evolução urbana. Na última década do século XIX a cidade passa de cerca de 65 mil habitantes para 240 mil. Cresce de imediato a demanda por habitações populares."

34. ANDRADE, Margarida Maria de, Bairros Além-Tamanduateí: o imigrante e a fábrica no Brás, Mooca e Belenzinho. Tese de Doutoramento apresentada na Faculdade de Filosofia, Letras e Ciências Humanas da Universidade de São Paulo - Departamento de Geografia, São Paulo, 1991, p.36. 
do uso rural para o uso urbano na organização espacial da Penha. Aprofundaremos esta análise no capítulo segundo desta dissertação.

Quanto ao papel da Igreja Católica no processo de configuração do espaço penhense, como é sabido, o Catolicismo Romano se apresenta marcante na configuração do espaço urbano brasileiro, tanto que a maioria dos núcleos de povoamento antigo da cidade de São Paulo (Penha, Nossa Senhora do Ó, Santana, Santo Amaro e Pinheiros) tem sua origem vinculada à construção de capelas e igrejas.

Como já foi apresentado aqui, é em torno da paróquia e de suas práticas religiosas que se organiza a vida de bairro. O fervor religioso e seus ritos dedicados a Nossa Senhora da Penha de França historicamente marcaram a Penha desde sua fundação e acabaram por dar-lhe identidade e funcionalidade peculiares.

Segundo Seabra, ao estudar a participação da Igreja Católica na configuração urbana do bairro paulistano do Limão, afirma que:

No Brasil colônia, toda cidade era uma formação de tempos lentos, plena de estabilidades que se moviam sob o primado de uma concepção clerical do mundo. Mas foi a colonização portuguesa que proveu de conteúdos a história urbana pregressa através de uma prática político-econômica que permitiu à religião penetrar profundamente na vida social, estabelecer conexões profundas, a tal ponto que formou uma base religiosa capaz de traduzir-se como modo de ser, chegando portanto a integrar a esfera que denominamos cultura. Em decorrência, o catolicismo forneceu o 'pano de fundo', o cenário ritual para os momentos fundamentais da vida, de um modo generalizado. ${ }^{35}$

Outro ponto importante da análise de Seabra está na identificação de dois planos distintos, mas convergentes sobre a ação Igreja Católica Apostólica Romana:

[...] um bem alto, que sintetizou o mando, o comando e correspondeu à supremacia do poder eclesiástico, centrado no papado, de onde se organizou uma hierarquia de mando, com valores capazes de fundar uma concepção clerical do mundo. $\mathrm{O}$ outro plano foi aquele da sua territorialidade, no qual tal ordenação abstrata do mando deveria realizar-se; era o bispado, com paróquias e freguesias. Em grande medida a vida de bairro definiu-se por suas relações paroquiais. Em todo o Ocidente a Igreja secularmente atuou circunscrevendo o plano da existência cotidiana dos sujeitos e ganhou presença comandando o tempo da vida e da morte. ${ }^{36}$

Portanto, o entendimento da formação social e das estruturas que marcaram a configuração espacial penhense necessariamente passa pelo entendimento das estruturas e práticas da Igreja Católica, pois, em torno dessas estruturas e práticas concretas é que se estabeleceram as relações de compadrio, de parentesco, de vizinhança com toda a cumplicidade que implicam. ${ }^{37}$

Segundo Seabra, na relação bairro-paróquia,

${ }^{35}$. SEABRA, O, C. L., op. cit., 2003, p.4.

${ }^{36}$. Ibidem, p.23.

${ }^{37}$. SEABRA, O. C. L., op. cit., 2000, p.12 e 2003, p.6. 
[...] o que nos interessa particularmente é que a vida de bairro implicou uma prática social imediatamente espacializada no bairro. Isto fez do bairro uma unidade socioespacial quase completa. Fez do bairro um espaço de representação da vida. Fosse através dos enterros, dos casamentos, das missas, das festas, das procissões, da feira semanal, da presença do louco conhecido de todos, da presença do bêbado, da meretriz, do padre, do médico de bairro, da professora [...] esse teatro acontecia sob hierarquias da Igreja e do Estado, que seguiam organizando e impondo divisões. ${ }^{38}$

Sob total influência da religiosidade, os arruamentos de antigos aglomerados urbanos como a Penha atendiam às necessidades diretas das capelas. Tal procedimento resultou em uma malha repleta de vias tortas e estreitas, impressas no sobe-desce de colinas e com calçadas apertadas dificultando em muito a circulação de veículos e pedestres. $^{39}$

Segundo análise de Aroldo de Azevedo, que pode ser facilmente estendida à Penha, "no que tange aos aglomerados 'espontâneos' ou 'naturais', a irregularidade do plano e o traçado tortuoso das ruas constituem a regra geral, gerando estruturas inorgânicas como as do núcleo primitivo da cidade de São Paulo. „40

Na Penha, até meados dos anos de 1940, a Igreja Católica se apresentou como centralidade e de suas práticas se estabelecia o ritmo de vida dos moradores. Durante longos anos, tal centralidade além de reunir os moradores para as atividades lúdicas que davam o ritmo da vida (a procissão, a missa, a quermesse, entre outros), também se apresentava como referência na escolha do local do encontro, da troca comercial, da troca de experiência, dos conflitos e disputas políticas que se apresentavam como a essência da vida local. A Igreja como mediadora das relações sociais não pode ser negligenciada no estudo de espaços como a Penha.

Para melhor entendimento da religião e a religiosidade na configuração do espaço penhense, a dissertação também procura retratar as práticas sociais resultantes da influência do catolicismo rústico e do catolicismo oficial até o momento que temos a inserção do morador penhense no mundo do trabalho.

Inseridos no tempo do trabalho, esse morador e sua família pouco tempo tinha para participar das festas e ritos da Igreja Católica local e, muitas vezes, até acabava se tornando opositor e até sabotador dos interesses católicos locais, pois por se tratar na grande maioria de imigrantes, trazia em sua bagagem novas vivências religiosas

38. SEABRA, O. C. L., op. cit., 2003, p.26.

39. MARX, Murillo. Cidade Brasileira. São Paulo: Editora Universidade de São Paulo / Edições Melhoramentos, 1980, p.42. Para o autor, nos antigos aglomerados e vilas, a trama urbana apresentava traçado "geralmente tortuoso", ora largas e ora estreitas, e que sempre ligavam uma construção religiosa à outra. 
(protestantismo, espiritismo etc.) e ideologias políticas (comunistas e anarquistas) que de imediato chocavam com o tradicionalismo local.

Sobre esse processo afirma Seabra, “a religião e a religiosidade começavam a serem modificadas, claro que de modo inconsciente e muito, mas muito lentamente, pois é assim que se expressam os fenômenos culturais."41 Incorporadas à cidade, pela industrialização e urbanização rápida, tais mudanças sócio-culturais, apoiadas em interesses sócio-econômicos e políticos, acabaram por trazer profundas mudanças na vida penhense. Mais tarde e seguindo a mesma lógica tais mudanças foram determinantes na implosão definitiva da vida de bairro a partir da década de 1950.

Como elemento nuclear e centralizador da vida de bairro, por muito tempo a Igreja também se fará presente no papel de valorização do espaço. Próximo à Igreja se concentrava maior infra-estrutura, o núcleo comercial, os organismos públicos, etc. e principalmente a moradia das classes mais abastadas e tradicionais do bairro. Em contrapartida, o maior afastamento definia predominância das moradias mais simples e rurais.

Como o recorte temporal da pesquisa foi estabelecido da origem do pequeno aglomerado da Penha até meados da década de 1950, da análise das continuidades e descontinuidades históricas espera-se um entendimento melhor dos conteúdos qualitativos sem negligenciar o desenvolvimento dos conteúdos quantitativos que começavam a tomar forma na Penha. Já podemos adiantar que o qualitativo conseguiu se sustentar por muito tempo, mesmo com o advento da industrialização.

Segundo Seabra, após os anos de 1950 a cidade expandiu e explodiu e a propriedade territorial apresentou-se como nexo fundamental da reprodução da sociedade,

[...] portanto, na história urbana o bairro seguiu com sua própria negação, que era a funcionalização do espaço e do tempo, era o domínio do quantitativo, o aniquilamento da espontaneidade experimentada nas formas lúdicas [...] a urbanização foi configurando a metrópole: uma superfície de urbanização contínua, domínio do quantitativo porque regido pelo princípio: 'o tempo é dinheiro’. Contudo, na metrópole não se pode suprimir espaços qualitativos porque sem eles não há vida. Mas nestas condições, a quantidade se insere sobretudo nos circuitos do mercado; nos clubes fechados e no movimento da indústria do entretenimento. O nível de relações imediatas tende a ser restrito ao domínio da casa. ${ }^{42}$

É possível observar que todas as análises até aqui propostas acabaram por esbarrar na abordagem da relação entre o rural e o urbano. De antemão podemos afirmar que não

40. AZEVEDO, Edgard de A. Vilas e Cidades do Brasil Colonial. In: Anais do Departamento de Geografia, Associação de Geógrafos Brasileiros, São Paulo. 1956. p.153.

41 . SEABRA, O. C. L., op. cit., 2000, p.14.

${ }^{42}$. Ibidem, p.17. 
se trata de tarefa fácil estabelecer limites entre um e outro, pois as implicações práticas de um sobre o outro estão presentes tanto nas representações físicas (ruas, praças, casas, igrejas), quanto nas abstratas (símbolos, ideologias, religiosidades, sentimentos, culturas) de ambos e nem sempre se revelam de imediato.

O rural e o urbano carregam consigo elementos e funções formados a partir das experiências vividas desenvolvidas no âmbito das trocas sociais e econômicas em acordo com seu momento histórico. ${ }^{43}$

A partir da perspectiva histórica e estabelecendo como referência a dinâmica das relações sociais que produzem o espaço, tornou-se possível compreender as sobreposições de antigos e de recentes processos de estruturação espacial no bairro. Assim, o estudo do processo histórico apresenta-se como procedimento metodológico.

Justificamos a reconstituição histórica pela idéia de que, na paisagem, as novas formas convivem com as formas antepassadas, portanto guardam consigo heranças que revelam a acumulação de diferentes tempos históricos. Portanto o espaço se apresenta como uma realidade social em constante processo de transformação, ou seja, “ $a$ acumulação do tempo histórico permite-nos compreender a atual organização espacial [...] assim sendo, torna-se relevante insistir no conceito de estrutura espaço-temporal em uma análise do espaço geográfico ou espaço concreto. „44

Partindo do processo histórico enquanto recurso metodológico de entendimento das espacialidades na Penha, foi possível estabelecer a hipótese de que a localidade passou por três períodos: a constituição da Penha enquanto bairro rural, a constituição da Penha enquanto subúrbio e a Penha como bairro paulistano.

Tal hipótese não se define aleatoriamente e apareceu depois de considerável reflexão dos processos sociais que se estabeleceram ao longo do tempo na localidade. A própria história da localidade nos dava indícios da possibilidade da elaboração de tal hipótese, no entanto a proximidade com a cidade de São Paulo se apresentava como impedimento para de defendê-la: sempre nos dava a impressão de estarmos seguindo caminho inadequado. Como alegar que a Penha tenha conseguido se manter isolada tempo suficiente para que a condição de bairro rural e subúrbio se constituíssem?

A complicação estava na possível centralidade que a cidade exercia sobre a localidade e, no entanto, foi da análise dessa centralidade que a hipótese se fortaleceu. Tal centralidade sempre existiu. No entanto, as dificuldades para relações mais intensas entre

43. QUEIROZ, M. I. P., op. cit, 1978, p.281-283.

${ }^{44}$. SANTOS, Milton. Espaço \& Método, $3^{\mathrm{a}}$ edição, São Paulo: ed. Nobel, 1992, p.53. 
a localidade e a cidade de São Paulo justificam pensar na Penha como bairro rural e como subúrbio, antes de se configurar como bairro paulistano, a religiosidade garantindo a unidade e a individualidade da localidade, pelo menos até à década de 1940.

A realidade suburbana, que parece ter se mantido até os anos de 1930, vai se desfazendo como resultado da intensificação da urbanização das relações dos moradores da Penha com o Centro da cidade e com os bairros mais centrais. Ao que tudo indica, a Penha a partir de meados dos anos de 1940 é mais um bairro paulistano entre tantos outros (ainda que Aroldo de Azevedo tenha preferido considerá-lo um bairro-subúrbio paulistano). A vida de bairro propriamente dita teve, no caso da Penha, pequena duração, sucumbindo à medida que a urbanização ganhava características metropolitanas.

Para o desenvolvimento desta pesquisa recorremos a diversos autores: Aluísio Wellichan Ramos, André R. Martin, Antonio Cândido, Antonio Carlos Boa Nova, Aroldo Edgard de Azevedo, Henri Lefebvre, José de Souza Martins, Hedemir Lingüite, Juergen Richard Langenbuch, Margarida Maria de Andrade, Maria Candido V. Santarcangelo, Maria Isaura Queiroz, Milton Santos, Odette de Carvalho Seabra, Pedro A. de Oliveira, Pierre George, Raquel Glezer, Richard M. Morse, Rui Cirne Lima, Silvio Bontempi, entre tantos outros. Recorremos, também, a documentos e manuscritos das entidades que preservam a memória da cidade de São Paulo: Arquivo da Cúria Metropolitana, Arquivo do Estado, Biblioteca Mário de Andrade, Conselho do Patrimônio Histórico, Arqueológico, Artístico e Turístico do Estado de São Paulo (CONDEPHAAT), Memorial Penha de França, Museu Paulista, Secretaria Municipal do Planejamento da Prefeitura do Município de São Paulo, entre outros. Recorremos, ainda, a antigos moradores do bairro que com sua memória permitiram sanar diversas dúvidas que foram surgindo ao longo da pesquisa.

Da hipótese, para a exposição dos resultados da pesquisa, surgiram os três capítulos da dissertação. No entanto, pelo próprio caráter do processo histórico, esses capítulos não devem ser compreendidos como isolados, já que os momentos (ou espaços) aqui identificados como do bairro-rural, do subúrbio, do bairro e, hoje, do não-bairro, se interpenetram, se implicam reciprocamente.

No primeiro capítulo procuraremos resgatar a história da Penha enquanto bairro rural. Nesta condição, urbano e rural coexistem, porém, os elementos que ditam as relações sócio-econômicas e culturais estão mais associados ao campo e são predominantes em relação aos elementos da cidade. Neste período, pudemos observar os 
mesmos aspectos culturais das sociedades agrárias analisadas nos trabalhos de Maria Isaura Pereira de Queiroz, Antonio Candido e Ernani Silva Bruno.

Esse primeiro capítulo deve ser compreendido como ponto de partida para o estudo das transformações que se efetuaram na localidade estudada. Nele resgataremos a gênese do aglomerado e encontraremos subsídios para compreender a ação conjunta do Estado e da Igreja Católica na sua formação histórica e espacial.

Como esse período é o dos domínios colonial e imperial, o capítulo procura delinear as estruturas político-jurídicas e ideológicas que definiam o uso do espaço na época.

No segundo capítulo procuramos examinar a Penha não mais como um bairro rural, mas como um subúrbio próximo. Nesta condição, os elementos sócio-econômicos e culturais da cidade passam a predominar sobre o rural e a Penha se apresenta como espaço de expansão do urbano, sua funcionalidade também é claramente definida pela cidade e os elementos concretos e abstratos estruturam-se associados aos fenômenos da urbanização e da industrialização.

Neste capítulo, procuraremos identificar a Penha enquanto espaço crescentemente urbano e, para justificar a sua constituição enquanto subúrbio, nos apoiamos em Juergen Richard Langenbuch, Aroldo Edgard de Azevedo, Richard M. Morse, José de Souza Martins, entre outros.

Nesse período abordaremos as transformações do espaço penhense a partir da chegada da ferrovia, da intensificação dos processos de industrialização e urbanização em curso na cidade de São Paulo. Observaremos como se efetuou a valorização da terra local e a transformação das antigas chácaras em loteamentos para famílias de operários.

Analisaremos também as modificações culturais que esses processos acabaram por deflagrar na localidade, onde poderemos observar os conflitos entre o tradicionalismo, representado pela Igreja e seus simpatizantes, e as novas concepções de mundo presentes entre os novos moradores da localidade.

Encerraremos esse capítulo na década de 1930 quando, ao que tudo indica, o bairro se sobrepõe ao subúrbio.

No terceiro e último capítulo observaremos a ampliação e a generalização da sociedade urbana sobre a localidade e a total subordinação do bairro pelo urbano metropolitano. 
Neste capítulo procuraremos observar as transformações que se processam na localidade entre as décadas de 1940 e 1960, ou seja, como se efetua a dissolução da vida de bairro e quais suas implicações sobre o uso do espaço.

Nas considerações finais, a partir do que foi apresentado ao longo do trabalho, retomaremos os questionamentos e hipóteses apresentados nesta Introdução. 


\subsection{Considerações iniciais}

Segundo Morse, a colonização da América Latina, tanto espanhola quanto portuguesa, foi fruto de uma mentalidade urbana, isto é, teve em um núcleo urbano o ponto de partida para a colonização. ${ }^{45}$ Muitas vezes, os pequenos núcleos eram abandonados ou transferidos de lugar, os lugares de sua implantação sendo escolhidas de forma arbitrária e mal orientada. Segundo Morse,

[...] os primeiros a chegar à América tomaram posse das terras à volta das novas cidades e reservaram direitos especiais para seus descendentes. Assim, um primeiro momento de democracia social foi seguido pela consolidação de uma oligarquia baseada na posse da terra e na prioridade da data da chegada. ${ }^{46}$

Com exceção dos centros burocráticos e comerciais, o urbano nas colônias da América Latina se caracterizou pela irradiação territorial dos descendentes dos primeiros colonizadores e, sempre de modo centrífugo, em direção ao rural. ${ }^{47}$ Assim, não havendo estímulos para o desenvolvimento de grandes centralidades urbanas acabou proporcionando redes urbanas frágeis e isoladas. A própria política mercantilista das coroas, que pouco faziam para o desenvolvimento urbano nas colônias, ${ }^{48}$ contribuía para essa condição.

Segundo Martin,

[...] o objetivo primordial da empresa colonizadora comandada pelo capital mercantil consistia na extração de valores de uso efetuada nos domínios coloniais para sua posterior realização como valores de troca na Europa. Foi exatamente para atender a tal orientação que paulatinamente, ao longo de três séculos, foi se formando uma estrutura urbana de tipo colonial entre nós. ${ }^{49}$

$\mathrm{O}$ autor ressalta que os primeiros núcleos fixos surgem das chamadas feitorias (armazéns militarizados com povoamento estável cuja atividade principal era o escambo do pau-brasil) e que só com a implementação do cultivo da cana-de-açúcar é que se consolidaram núcleos urbanos mais sólidos próximos ao litoral. ${ }^{50}$

Os aglomerados mais distantes do litoral, tributários de uma economia de subsistência, pouco se desenvolviam. Segundo Martin, como conseqüência das condições acima,

45. MORSE, Richard M. Formação histórica de São Paulo (de comunidade à metrópole). São Paulo: Difusão Européia do Livro, 1970, p.12.

${ }^{46}$. Ibidem, p.11.

${ }^{47}$. Idem.

${ }^{48}$. Ibidem, p.12. Segundo Morse, "as cidades do Novo Mundo tenderam a ligar-se individualmente às metrópoles ultramarinas e a isolar-se uma das outras".

${ }^{49}$. MARTIN, André, R. O bairro do Brás e a "deterioração urbana". Dissertação de Mestrado. FFLCH-USP - Departamento de Geografia. São Paulo, 1984, p.3-5.

${ }^{50}$. Ibidem, p.3-5. 
[...] gerou-se no conjunto uma rede urbana ao mesmo tempo concentrada e débil, praticamente sem nenhuma articulação interna. Assim também a vida urbana tinha um caráter intermitente, uma vez que os senhores permaneciam a maior parte do ano em suas fazendas, dirigindo-se aos centros urbanos só eventualmente, e em épocas determinadas, apenas com a finalidade de cumprir obrigações religiosas, administrativas e comerciais, e também para tomar um pouco mais de contato com a cultura européia. Enfim, um quadro urbano extremamente modesto e rústico aparecia como decorrência necessária do caráter essencialmente rural da colonização e do povoamento. ${ }^{51}$

Assim, os pequenos aglomerados urbanos que surgem no período colonial se organizam sob absoluta dependência da produção rural e tal condição se arrastará pelo menos até meados do século dezenove. ${ }^{52}$

Esse quadro será a base de entendimento da constituição da Penha enquanto bairro rural.

Contribuíam também para a debilidade das redes urbanas as barreiras geográficas. As distâncias e a aspereza da natureza tornavam a circulação das pessoas e mercadorias extremamente dificultosa. A ligação entre os centros urbanos acontecia por caminhos longos, tortuosos e perigosos que requeriam muito tempo de viagem e muitas paradas para descanso.

É uma destas paradas que está na gênese da porção da cidade de São Paulo que foi identificada como Penha. Este é o ponto de partida da análise que nos propusemos a fazer.

\section{$\underline{1.2}$ Uma capela, uma sesmaria: nasce o aglomerado}

A história conta que a Penha surgiu de uma lenda relacionada às figuras de um possível viajante francês e de sua santa de devoção: Nossa Senhora da Penha de França. Hedemir Linguite conta a saga segundo a qual o tal viajante

[...] fazendo o trajeto de São Paulo ao Rio de Janeiro, [...] por duas vezes viu-se obrigado a retroceder, à procura de uma imagem de Nossa Senhora da Penha de França. A imagem, por duas vezes, teimosamente, sumira dos pertences de nosso viajante, vindo encontrá-la no alto de uma colina, [...] o viajante viu naquele fato em duas seqüências, que a imagem ali desejava ficar, e para tanto foi construída uma modesta ermida para abrigar a referida imagem. ${ }^{53}$.

\footnotetext{
51 . Ibidem, p.6.

52 . Idem.

${ }^{53}$. LINGUITE, Hedemir. Santuário de Nossa Senhora da Penha. São Paulo: s/editora, s/data, p.10.
} 
Assim, verdade ou não, surge o mito milagreiro de Nossa Senhora da Penha e sua pequena ermida.

Segundo Santarcangelo, “em documentos antigos constantes do Arquivo Histórico da Prefeitura, vemos citações da Penha já datadas de 1715, bem como outras de 1748 e $1749 " .54$ Nessas citações são encontradas tanto referências à ermida quanto ao pouso para viajantes e suas tropas.

Por hora, preferimos dar como momento de origem do aglomerado a segunda metade do século dezessete, quando uma sesmaria foi concedida ao licenciado ${ }^{55}$ Matheus Nunes de Siqueira em 5 de setembro de 1668 pelo capitão-mor Agostinho de Figueiredo. $^{56}$

Segundo Bontempi, nesta petição, que pode ser encontrada no Livro $11^{\circ}$ de Sesmarias Antigas da Tesouraria da Fazenda de São Paulo, era solicitada uma área que possuía uma ermida e algumas campinas, brejais e restingas que poderia ser utilizada para a produção agrícola. ${ }^{57}$

Arroyo ressalta que Matheus Nunes de Siqueira, ao solicitar a sesmaria, alegou que além do uso agrícola das terras também se preocupava com outra questão que

${ }^{54}$. SANTARCANGELO, Maria Cândido Vergueiro. Bairro da Penha 1668-1968. São Paulo: s/editora, 1968, p.5. Livro lançado em homenagem ao terceiro centenário da Penha (1968). Este material somente pôde ser consultado graças ao CD-ROM Retratos da Penha, produzido pelo Memorial Penha de França em 2004, sob a organização de Francisco Falco. Neste CD, o livro se encontra reproduzido integralmente e as indicações de página são referentes ao CD-ROM e não ao livro original. A autora ainda ressalta que "inúmeras versões existem a respeito da origem da primeira ermida de Nossa Senhora da Penha de França. [...] A modesta capelinha deve ser anterior a 1667 [...] segundo a tradição popular, muitos moradores locais, em vida, deixavam a vontade expressa de serem sepultados na Igreja de Nossa Senhora da Penha de França, como Henrique Lobo, Maria da Costa, Henrique da Cunha Machado, Mariana Maciel e outros, como era costume de outrora. Alguns testamentos datavam da primeira metade do século 17, o que faz supor que tenha sido a capela erguida entre 1630 e 1650.”

${ }^{55}$. O título de licenciado era conferido aos trabalhadores autônomos que possuíam autorização da Coroa para exercerem suas profissões.

${ }^{56}$. SANTARCANGELO, M. C. V., op. cit., 1968, p.5.

57. BOMTEMPI, Silvio. O Bairro da Penha. São Paulo: Departamento de Cultura da Secretaria de Educação e Cultura da Prefeitura do Município de São Paulo, 1969, p.37-38. Conforme Bontempi: “Diz o licenciado Matheus Nunes de Siqueira, morador na villa de S. Paulo, que elle suplicante tem uma fazenda com ermida e curral de gado légua e meia d'esta villa, na paragem chamada Tatuapé, terras que houve dos herdeiros do defunto Francisco Jorge, e por quanto não tem terras para lavra, e na testada d'estas terras para o Rio-Grande (assim chamavam os antigos o Rio Tietê) em uma volta que faz o rio tem um pedaço de terra dentro da qual há algumas campinas, brejaes e restingas de mato que se pode lavrar, por isso pede a Vossa Mercê que, como procurador bastante do donatário, lhe faça mercê dar por carta de sesmaria a terra que pede para maior augmento da capella, havendo também respeito ser o supplicante filho e neto de povoadores e não ter até gora carta de sesmaria; a qual terra correrá de umas campinas que partem da banda de baixo do ribeirão de Tatuapé, correndo pelo Rio-Grande a riba pela volta que faz por uma campina que chamam Itacurutiba até uma aguada que foi do defunto João Leite.” Segundo Santarcangelo, Matheus Nunes de Siqueira possuía uma casa que havia sido construída em 1650 localizada " junto ao Córrego do Tatuapé na várzea do Tiête. Constava de um pavimento de chão socado, paredes de taipa de barro, forro de esteiras de taquara e telhas. Rebocada e caiada. Aí se iniciou a fazenda e ao seu redor foram construídas as casas dos colonos.” (SANTARCANGELO, M. C. V., op. cit., 1968, p.4-5.) 
classificou como "motivo extremamente piedoso" localidade.

Arroyo, assim como Santarcangelo acrescentam que o filho de Matheus Nunes de Siqueira, Jacinto Nunes de Siqueira, tornou-se o responsável pela dita ermida e passou a reformá-la. $^{59}$

Acreditamos que tal reforma já fosse parte do desejo do sesmeiro e de seu filho de pedir o reconhecimento oficial do templo. Desta feita, em 1762 a ermida, que se localizava no topo de uma colina cortada por uma vereda que se direcionava para a aldeia de São Miguel de Ururaí $^{60}$ e daí para São Sebastião do Rio de Janeiro, se transforma em capela, data até hoje encontrada sobre a porta do antigo templo de Nossa Senhora da Penha.

A ermida foi reformada e ampliada por Jacinto Nunes de Siqueira, transformandose em uma capela. Em pouco tempo um pequeno agrupamento de casebres rústicos arrodeou a dita capelinha e, mais tarde, configurou um pequeno aglomerado. ${ }^{61}$

${ }^{58}$. ARROYO, Leonardo. Igrejas de São Paulo. José Olympio. Rio de Janeiro, 1954, p.173-174. Segundo o autor, a família de Matheus Nunes de Siqueira era muito religiosa e já tinha participado da fundação de outra capela e assinala a existência de um "[...] título de ereção e instituição da capela do 'Snor Jezus sita na Matriz desta Cid $^{a}$ e fundada por Maria de Siqueira e seu Filho o L. ${ }^{\text {cdo }}$ Matheus Nunes Siqueyra (que) é de 1663 [...] Homem religioso, repitamos, e nada seria de estranhar, portanto ter também fundado a igreja de Nossa Senhora da Penha. Antecedentes não lhe faltavam para tanto. Seu herdeiro, o padre Jacinto Nunes, dotou-a de bens de raiz, decorrendo daí sua participação no antigo templo".

${ }^{59}$. Ibidem, p.171.

60. SANTARCANGELO, M. C. V., op. cit., 1968, p.3-5. Segundo a autora, "os silvícolas dessa tribo [Ururaí], subordinados ao cacique Piquerobi, eram Guaianases e pertenciam à grande nação Tupi. Eram arregimentados em aldeias. Tinham áreas primitivas. Possuíam títulos concessionários. Habitavam toda a margem esquerda do Rio Grande, ou seja, Tatuapé, Penha e São Miguel [...]” A autora também levanta outras hipóteses sobre a origem da Penha alegando que o arraial surgiu do aldeamento citado acima; uma segunda hipótese "de ter sido a trilha por onde os altivos filhos de Tibiriçá teriam acesso à Bertioga.” ; Uma terceira, “[...] de ter sido um pouso ameno, aprazível, de onde se descortinava toda a Vila e onde acampavam os bandeirantes que demandavam as "Minas Gerais dos Cataguás". Por ali alcançavam o vale do Paraíba, através da Serra da Mantiqueira, na altura de Lorena." Outras duas: "Seria, ainda, o carreador onde tropas de burros ou boiadas transitavam a caminho das feiras de gado. Devemos salientar que, nessa época, nas estradas, havia paradas ou pousos obrigatórios, onde os ranchos de tropas se instalavam. Os itinerantes repousavam. As cavalgaduras eram descarregadas e saciadas. Geralmente, esses locais se situavam à beira dos córregos, para dessedentar os tropeiros e seus animais. Poderia, ainda, justificar a origem do núcleo penhense, a corrida do ouro, no fim do século 16, nos arredores de Nossa Senhora da Conceição dos Guarulhos, um dos primeiros aldeamentos criados pelos congregados de Santo Inácio de Loiola. Afonso Sardinha, em 1597, descobriu quatro minas auríferas, inicialmente. Depois, outras foram sendo descobertas. Todas se situavam nos bairros de Lavras, Catas, Velhas, Campo dos Ouros, Tanque Grande, Monjolo de Ferro e Bananal, hoje Município de Guarulhos. Muitos outros exploradores sucederam a Afonso Sardinha e seu filho, mediante Cartas de Sesmarias e essas propriedades se estendiam até a Penha, onde, perto do riacho Tiquatira, segundo a tradição, existiu ouro". Porém, a hipótese histórica associada ao licenciado Matheus Nunes de Siqueira é mais provável e aceita.

${ }^{61}$. BONTEMPI, S., op. cit., p.56-57. O autor alega que já existia um pequeno aglomerado em 1687. 
Segundo Bontempi, a terra concedida a Matheus Nunes de Siqueira ficava a uma légua e meia a leste ${ }^{62}$ do que, a partir de 1724, seria conhecido como marco do rocio, o Marco de Meia Légua. ${ }^{63}$

Segundo Deli, a sesmaria de João Ramalho começava a meia légua da vila de São Paulo, e seguia mais ou menos paralelo ao curso do rio Tietê até onde começavam as seis léguas em quadra que compunham o aldeamento de São Miguel do Ururaí. ${ }^{64}$

Segundo Deli, a sesmaria recebida por Matheus Nunes de Siqueira, em 1650, era parte da sesmaria de João Ramalho e seu filho Antonio de Macedo. ${ }^{65}$ Já Nuto Santa'Ana afirma que essa sesmaria, em 1655, pertencia aos filhos de Francisco Jorge. ${ }^{66}$ Essas referências também são encontradas em Bontempi e Arroyo. ${ }^{67}$ Assim, a sesmaria que se tornou o patrimônio religioso da freguesia de Nossa Senhora da Penha de França foi terra de João Ramalho e de seu filho, depois de Francisco Jorge e seus filhos, até ser concedida a Matheus Nunes de Siqueira. Poderemos observar a possível localização da sesmaria no Mapa 1 da página seguinte.

A solicitação de concessão de sesmaria apresentada por Matheus Nunes de Siqueira ao capitão-mor Agostinho de Figueiredo informa que a terra era "uma fazenda com ermida e curral de gado [...] um pedaço de terra dentro da qual há algumas campinas, brejaes e restingas de mato que se pode lavrar" ${ }^{\circ 8}$, o que revela que a mesma era pouco aproveitada.

Obter uma sesmaria não era tarefa complicada, mas devido às distâncias e desorganização do Estado colonial, tal aquisição se apresentava como um processo confuso, um tanto lento e burocrático; a imprecisão dos limites das propriedades também

\footnotetext{
${ }^{62}$. Ibidem, p 40.

${ }^{63}$. SANTARCANGELO, M. C. V., op. cit., 1968, p.21. De acordo com a autora, "Aos vinte e cinco de março de 1724, estabeleceu-se que São Paulo possuía uma área correspondente a uma circunferência de uma légua de diâmetro, tendo por centro o Largo da Sé. O Registro das Ordens Regias, Tomo II, livro manuscrito número cento e setenta, folha duzentos e noventa e oito, versão do Arquivo Municipal de São Paulo, esclarece que a Meia Légua foi demarcada pelo medidor do Conselho, Antônio da Silva Lopes, em quatro direções a saber: - 1) para o lado da Penha, no local ainda conhecido por Marco, onde existiu uma grande serraria; 2) para o lado de Santana, além do Tietê, na paragem do Areal; 3) para o lado de Pinheiros e 4) para o lado de Santos, altura do Ipiranga."

64. DELI, Fernando Rodrigues. A Importância do Povoamento e da Circulação no Processo de Fragmentação do Vale do Aricanduva. Trabalho de Graduação Individual apresentado ao Departamento de Geografia da Faculdade de Filosofia Letras e Ciências da Universidade de São ${ }^{65}$. Idem. Paulo, São Paulo, 1994, p.35.

${ }^{66}$. SANTA'ANA, Nuto. As Igrejas do Século da Fundação. In: Ensaios Paulistas. (Contribuição de 'O Estado de São Paulo’ às comemorações do IV Centenário da Cidade) São Paulo: Editora Anhembi S/A, 1958, p.489-490.

67. BONTEMPI, S., op. cit., p.37-38. ARROYO, L., op.cit., 1954, p.172.

${ }^{68}$. Ver, a respeito, nota 58.
} 
se apresentava como problema muito sério. Como veremos adiante, ambos os fatores resultariam em sérias dificuldades para a manutenção do sistema sesmarial.

Esses sesmeiros eram povoadores que se apresentavam com parcos recursos, alguns até tinham título de nobre, mas a maioria era de origem plebéia e haviam migrado em péssimas condições econômicas. ${ }^{69}$ Tinham acesso à terra somente quando eram considerados “homens bons".

${ }^{69}$. MORSE, R. M., op. cit., 1970, p.30. 


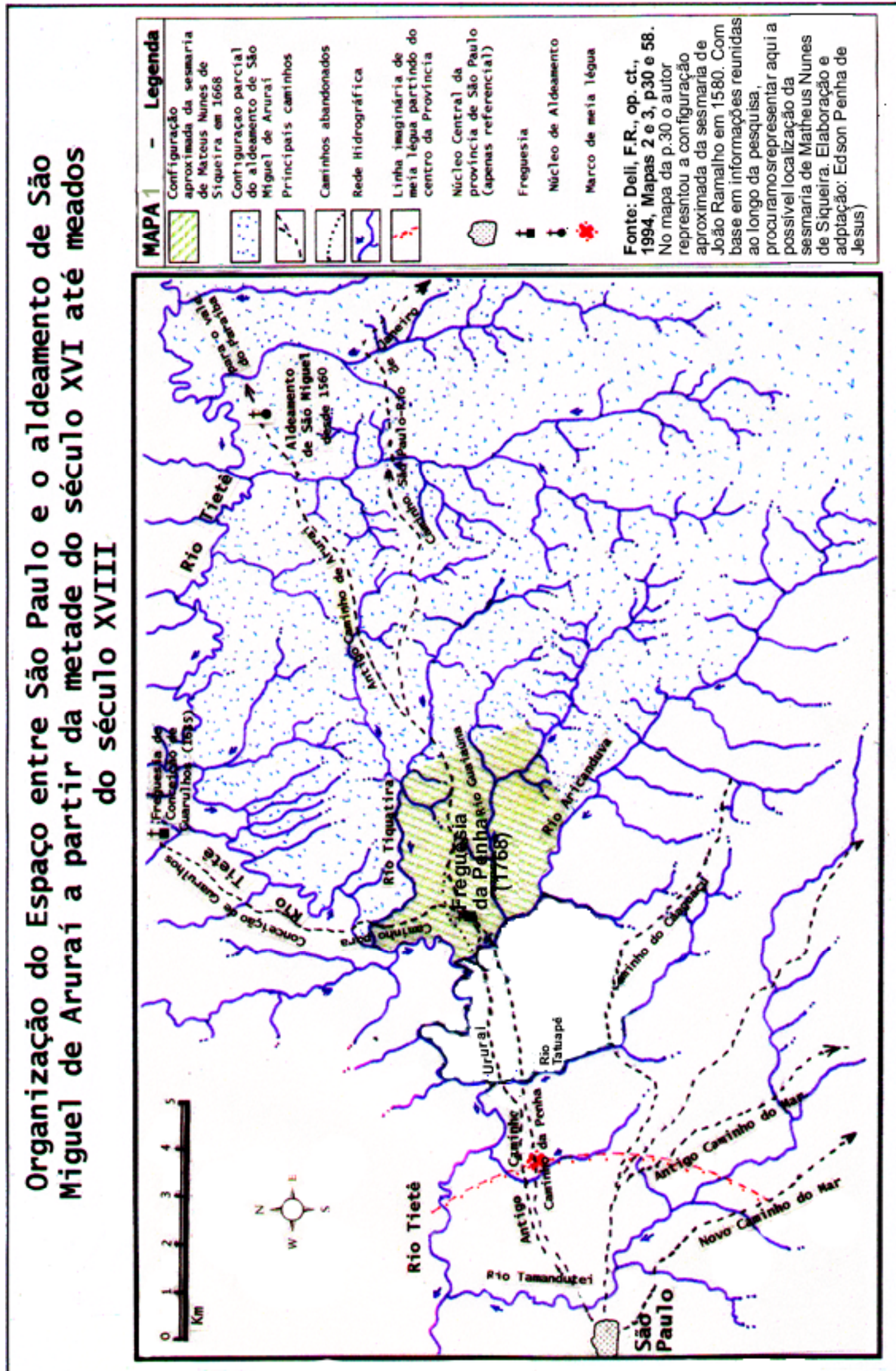


Segundo Morse, tais “homens bons” eram "geralmente proprietários cristãos, $e$ não judeus, estrangeiros, artesãos, trabalhadores rurais, exilados ou, falando de maneira ampla, gente do povo. O típico 'homem bom' era um patriarca senhorial, a que obedeciam uma numerosa família ampliada e dependentes."70 Esses "homens bons" asseguravam o funcionamento do sistema social seiscentista.

A ampliação do templo e o crescimento do aglomerado foi o progresso necessário para a configuração do patrimônio religioso penhense.

Os patrimônios religiosos, também conhecidos como arraiais, eram os espaços de uso eclesiástico e de uso comum e se originavam no interior de uma sesmaria, às vezes surgiam nas divisas de duas ou mais sesmarias. Conforme Murilo Marx,

[...] os patrimônios constituíam porções de terra cedidas por um senhor, ou por vários vizinhos, para servir de moradia e de meio de subsistência a quem desejasse morar de forma gregária e voltada para certas atividades ou que tivesse, no fundo, outro tipo de relacionamento de trabalho ou de troca com os doadores. $^{71}$

Eram pequenas parcelas de sesmarias destinadas à instalação de moradias daqueles agregados que não possuíam terras e que prestavam serviços ao sesmeiro. $\mathrm{Na}$ maioria das vezes desenvolviam rústicos equipamentos comerciais, como vendas e pousadas, para atender moradores locais e viajantes que por lá passassem.

Esses patrimônios religiosos surgiam de forma discreta e tímida. A grande maioria deles tinha sua origem na devoção de um santo e, pela lógica, as terras doadas passavam a se constituir patrimônio da capela do mesmo. Essa entidade, assim como sua capela, deveria ter o reconhecimento da Igreja e do Estado colonial.

Além da gleba, para o estabelecimento do patrimônio exigiam-se dotes iniciais e constantes como víveres, móveis, materiais de construção (para a ereção ou reforma do templo) e dinheiro para seu funcionamento. Segundo Murilo Marx, os sesmeiros

[...] propiciavam, assim, as condições para a construção do templo, para sua manutenção e reparo, para seu equipamento litúrgico e funcionamento efetivo. Em troca, os fundadores do patrimônio, os que tornavam possível a existência da capela, obtinham atenções especiais para si e para os seus em termos espirituais, como missas após a morte. ${ }^{72}$

A gleba do patrimônio religioso geralmente não costumava ser muito grande ${ }^{73} \mathrm{e}$ se estruturava da seguinte forma: no centro da gleba, o templo ou o espaço necessário

${ }^{70}$. Ibidem, p.31. O autor continua: "Dez ou dose filhos legítimos constituíam a norma em casamento, e dadas as condições precárias da vida, eram comuns os casamentos sucessivos. Além disso, as escravas, índias e depois negras, concebiam normalmente filhos dos seus senhores, que estes reconheciam em seguida de modo regular nos testamentos."

${ }^{71}$. MARX, Murillo, Cidade no Brasil: terra de quem? São Paulo: Edusp/Nobel, 1991, p.38. Segundo o autor, a grande maioria dos patrimônios era de origem religiosa, mas também existiam aqueles de origem leiga.

${ }^{72}$. Ibidem, p.39. 
para sua construção; no entorno deste, o terreno reservado a uma possível ampliação deste templo ou para futuros prédios de uso religioso, ou ainda para estabelecimento do adro ${ }^{74}$, do cemitério e para uso comunal (parte para pastagens e cultivo e para ser dividida em pequenas porções entre agregados).

Como tudo tem seu preço, a concessão dos pedaços da gleba para o estabelecimento de moradores ocorria mediante o pagamento de foro que era cobrado anualmente, dinheiro que costumava custear as despesas do templo. ${ }^{75}$

A Penha consolidou-se como patrimônio religioso a partir de 1682, ano em que se verifica a inauguração da capela. ${ }^{76}$

O Estado também se beneficiava com o aparecimento destes arraiais, ou patrimônios, ou capelas (três nomenclaturas com o mesmo significado) e mesmo à distância procurava estar atento sobre o que ocorria e, precariamente, tentava estabelecer certo controle do que neles se processava. Sobre esse ponto, justifica Murilo Marx,

[...] tratando-se esses patrimônios ou capelas de bens de mão-morta, ou seja, de bens que não se alienavam, transmitiam ou trocavam de mãos, deixando de pagar direitos como impostos [...] As ordenações do Reino estipulam cuidadosamente as condições de constituição das 'fábricas' e de gestão das capelas, bem como setores e autoridades encarregados de fiscalizá-las. ${ }^{77}$

Assim, as ordenações, por intermédio da Igreja garantiam a sobrevida de aglomerados como a Penha.

Nesta concepção de espaço a Igreja tem papel fundamental, pois através dela é que se estabelecia o cerne da relação de vizinhança que tão bem define a realidade de um

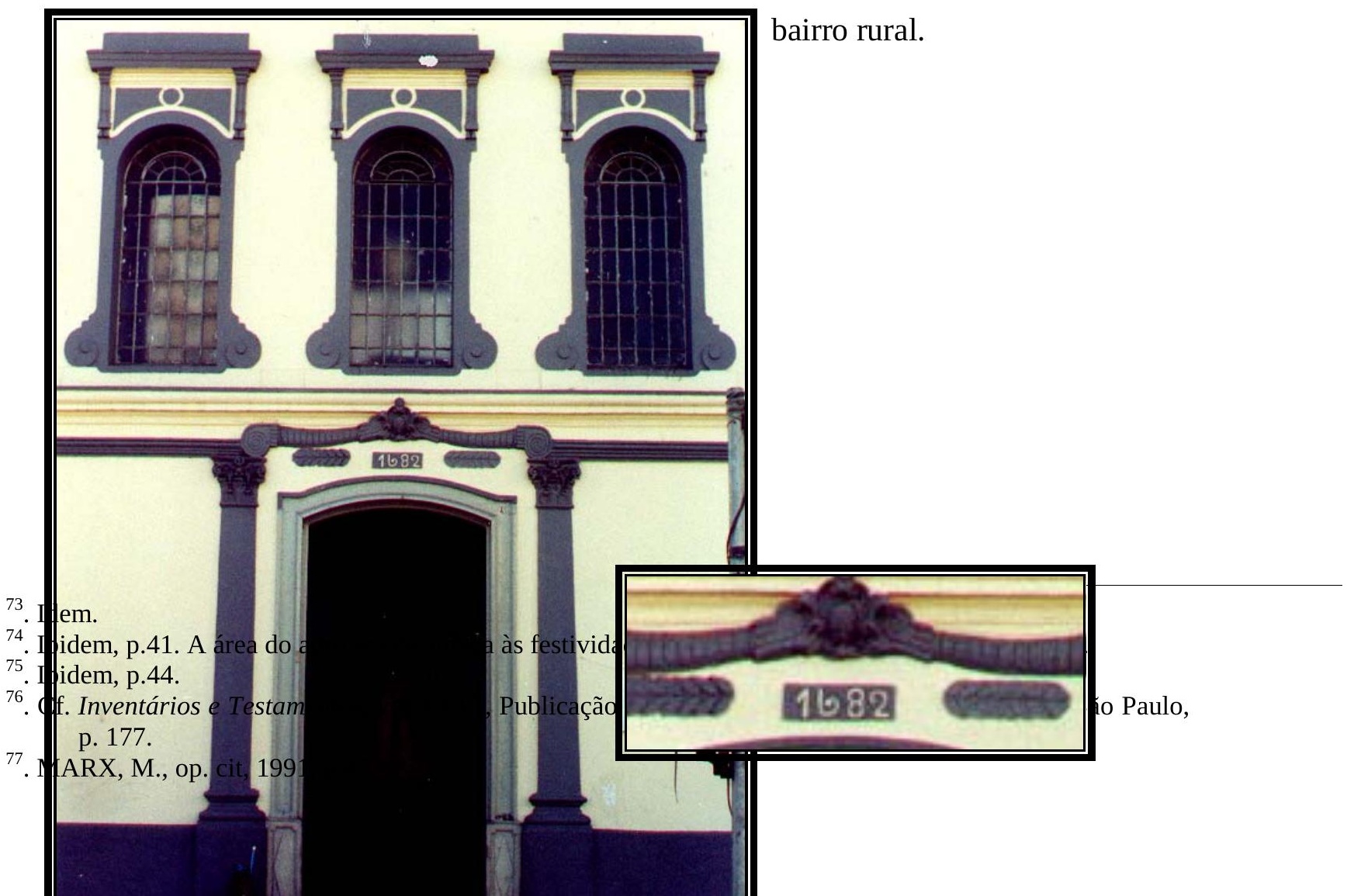


Antiga capela de Nossa Senhora da Penha - Observa-se na foto o ano de consolidação do patrimônio religioso e da inauguração da capela 1682 (Foto: Edson Penha de Jesus, 2002)

Como base cultural, o bairro rural tem no catolicismo rústico sua principal orientação. Assim, é a partir da presença do catolicismo rústico no espaço penhense que desenvolveremos a hipótese aqui levantada: a de que a Penha, em dado momento de sua história, reuniu um conjunto de características que justificam considerá-la um bairro rural.

\subsection{Penha: um bairro rural}

Uma vez que se estabelecia a mínima organização da freguesia, por seu caráter essencialmente centralizador, era natural o avanço das práticas de auxílio mútuo e de atividades lúdico-religiosas.

Tais práticas se apresentavam de grande valor para a comunidade, pois acentuava

o sentimento de pertencimento ou, como afirma Candido, um sentimento de localidade. ${ }^{78}$ As atividades lúdico-religiosas fortaleciam o simbolismo do núcleo.

A hipótese formulada de que mesmo se tornando freguesia a Penha continuou sendo um bairro rural, está embasada em elementos da história da localidade que se aproximam daqueles encontrados nos estudos sobre bairros rurais paulistas encontrados nas obras de Antônio Candido e Maria Isaura Pereira de Queiroz.

Sabemos que Candido e Queiroz não consideraram bairros da cidade de São Paulo como bairros rurais. No entanto, acreditamos que graças ao isolamento, à economia, à religiosidade e as demais práticas sociais que caracterizavam a freguesia de Nossa Senhora da Penha até meados do século dezenove, a condição de bairro rural não pode ser descartada. E mais, dizer que bastou a Penha receber o status de freguesia para a realidade 
de bairro rural desaparecer seria inconsistente. Todo o processo foi moroso e a Penha ainda manteve as características de bairro rural por muito tempo.

O estabelecimento da freguesia trouxe a administração canônica e todas as suas posturas que, de imediato, entraram em conflito com o catolicismo popular da localidade, pois determinaram novas regras para seus espaços sagrados. Como freguesia, a aproximação do aglomerado com a cidade de São Paulo se intensificou como veremos adiante.

Voltemos à fundamentação encontrada, que justifica a caracterização da Penha como bairro rural até meados do século dezenove.

Segundo Queiroz, em suas pesquisas sobre a origem e estrutura socioeconômica dos bairros paulistas, a identificação de pequenos povoados isolados pelo vocábulo bairro rural já era utilizado desde o século dezoito nas províncias de São Paulo e Minas Gerais. ${ }^{79}$ Em Candido também encontramos explicações parecidas,

[...] nos velhos documentos paulistas, bairro sempre aparece como divisão administrativa da freguesia, que o é por sua vez da vila. Esta era sede de Câmara e Paróquia e cabeça de todo o território, quase sempre vasto; a freguesia supunha um núcleo de habitação compacta e uma igreja provida de sacerdote, geralmente coadjutor do vigário da paróquia; o bairro era divisão que abrangia os moradores esparsos, não raro com sua capelinha e às vezes cemitério. O território das vilas, repartido em distritos, foi mais tarde, por sua vez, dividido em quarteirões, unidade que coincidia com o bairro, ora o incluía, mas de qualquer forma se baseava na sua existência. ${ }^{80}$

Candido reforça seu ponto de vista citando um documento da coleção das Ordens

Régias de 1725 onde se mencionam

[...] as freguesias seguintes: São João d'Atibaia, Nazaré, Juqueri, Conceição, Cotia, Santo Amaro, e os bairros: Tietê. N. S. ${ }^{a}$ do Ó, N. S. ${ }^{a}$ da Penha, São Miguel, São Bernardo, Caguaçu, Juá. Note-se que estes, providos de núcleo mais ou menos definido, são bairros apenas da cidade; os bairros das diferentes freguesias seriam quase sempre de tipo fracamente disperso $[\ldots]^{81}$

Segundo Bruno:

[...] fora de dúvida que particularmente de fins do século dezesseis em diante a zona rural ou semi-rural de São Paulo de Paratininga foi se estendendo de forma considerável. Já neste tempo se fez o que Taunay denominou a discriminação mais antiga que se conhece dos bairros de São Paulo: o Hipirangua, a Ponte Grande da Tabatingüera, Birapuera, Santo Amaro, os Pinheiros. Mas havia outros menos importantes: Piqueri, Sambatiba e Amabuaçava [...] Outras áreas da região de Piratininga se povoaram sobretudo depois de fins do século dezesseis: tendo passado o risco de ataques de índios, os colonos já se aventuravam a pedir terras em um raio mais largo [...] Na segunda metade do século dezessete os sítios e as fazendas já estendiam pelas zonas [...] Guapira - onde Fernão Dias plantou o trigo e a vinha - de Guarulhos, de Itaquaquecetuba, São Miguel, de Quitaúna, de

78. CANDIDO, A., op. cit., 1998, p.62.

79. QUEIROZ, Maria Isaura Pereira de. Bairros rurais paulistas: dinâmica das relações bairro rural-cidade. São Paulo: Livraria Duas Cidades, 1973, p.3.

${ }^{80}$. CANDIDO, A., op. cit., 1998, p.63.

${ }^{81}$. Ibidem, p.64. Os documentos que o autor cita tem a seguinte referência bibliográfica: “Ordens Régias”, RAM, LI, 1938, p.70,107 e 108. 
Carapicuíba - povoada por Afonso Sardinha - de Cutia, de Juqueri, de Paranaíba. Daí dizer uma ata da Câmara em 1655 que as fazenda dos moradores estavam já a mais de se seis ou sete léguas 'por caminhos fragosos` ${ }^{82}$

Bruno acrescenta que

[...] essas chácaras, quintas, roças e sítios espalhados pelos campos, ao redor do núcleo urbano mas às vezes a distâncias consideráveis, é que constituíam os 'bairros' a que se faziam referências, uma vez ou outra, as atas quinhentistas ou seiscentistas da Câmara de São Paulo. ${ }^{83}$

Levando em consideração as afirmações acima, podemos destacar que uma localidade, para ser considerada um “bairro”, apresentava-se com mínima função centralizadora, que servia de referência para os moradores da região, e uma porção de casas dispersas em chácaras ao redor. E mais, tal centralidade mínima vivia em função do campo e dos moradores do mesmo. Nela o modo de vida rural predominava.

Segundo Morse, a colonização, particularmente a do Brasil, tinha como ponto de partida o município, no entanto, “as instituições rurais tendiam a desenvolver-se fora do âmbito de controle municipal. A organização social rural passava a depender de formações de tipo patriarcal, da família ampliada ou do compadrio.”84 Nesse caso, a figura de sesmeiros como, Mateus Nunes de Siqueira, encaixava-se com correção. Não se diferenciando politicamente do campo, o aglomerado apresentou-se, como não poderia ser diferente, apêndice do campo. ${ }^{85}$

Na bibliografia pesquisada podemos observar que a Penha já recebia a designação de "bairro" mesmo antes de se configurar como freguesia: a Penha era considerada um dos “bairros” da freguesia da Sé.

As próprias características sócio-econômicas e culturais da localidade sugerem a condição de bairro rural. Segundo Queiroz, no bairro rural:

[...] estabelecia-se uma rede estreita de relações entre os roceiros pertencentes ao mesmo grupo de vizinhança, que adquiriam consciência da unidade e do funcionamento deste. Configuração social intermediária entre a família, de um lado, e de outro o arraial, ou a vila, ou a cidadezinha, o bairro apresentava as formas mais elementares de sociabilidade da vida rústica [...] os integrantes de um bairro rural eram sempre caipiras ou 'gente do sítio’: vivendo em casas tão precárias que mereciam o nome de ranchos; utilizando técnicas e processos rudimentares; consumindo os produtos que plantavam; vestindo roupas fiadas e tecidas por eles mesmos; empregando utensílios fabricados em casa (até pólvora e balas eram de fabricação caseira); comendo biscoitos confeccionados pelas mulheres da família; indo vender nas cidades próximas galinhas e leitões $[. . .]^{86}$

82. BRUNO, Ernani Silva. Histórias e Tradições da Cidade de São Paulo, Volume I-Arraial de Sertanistas (1554-1828). São Paulo: Editora Hucitec/ Prefeitura do Município de São Paulo - Secretaria Municipal de Cultura, 1984, p.184-185.

${ }^{83}$. Ibidem, p.186. Segundo Bruno, nestas chácaras e sítios, eram cultivados produtos trazidos de Portugal (trigo, vinha, cana-de-açúcar, legumes, fumo, etc. além de criação de porcos e outros animais) ao lado de espécies nativas.

${ }^{84}$. MORSE, R. M., op. cit., 1970, p.14-15.

${ }^{85}$. Ibidem, p.12-13.

${ }^{86}$. QUEIROZ, M. I. P., op. cit., 1973, p.4-5. 
Segundo Candido, a sociabilidade marcada pelas relações de vizinhança e pelo sentimento de solidariedade ligava-se diretamente à religiosidade centralizada na capela do bairro. ${ }^{87}$

Na Penha do século dezessete e até meados do século dezoito, as atividades e relações sócio-econômicas estabelecidas se associavam às necessidades de subsistências. O aglomerado que se estruturava apresentava-se economicamente isolado e com pequena população. No entanto, culturalmente já se organizava a partir de práticas religiosas, crenças e ritos originários do catolicismo popular, e da ordem colonial representada na figura do possuidor da sesmaria. O ritmo da vida era determinado pela natureza e a divisão social do trabalho era fraca. As relações sociais eram face a face e marcadas pela afetividade estabelecida nas relações de parentesco e compadrio. ${ }^{88}$

Nesse período histórico é possível observar que certo isolamento econômico marcava a economia local. E mesmo quando começaram as diversas trasladações da Santa da Penha para a cidade de São Paulo e vice-versa, essa condição econômica não se alterou. Somente a partir da segunda metade do século dezenove é que teremos alguma modificação. Veremos isso depois.

Segundo Queiroz, a definição de bairro rural também parte da

[...] forma específica de implantação no solo, - um 'habitat' disperso centralizado por pequeno núcleo de habitações em torno da capela, - e pelos vínculos sociais que unem seus membros. Tais vínculos se exprimem em relações de ajuda mútua, tanto no campo da economia quanto em outros campos sociais. ${ }^{89}$

Assim, as relações de vizinhança no bairro rural se estabeleciam a partir da ajuda mútua no momento de resolução de problemas individuais ou coletivos (havia mutirão para a derrubada de matas, fazer habitações, para o plantio, para o roçado, para a colheita e malhação, etc.). Os vizinhos também eram convocados para cuidar da porção central do bairro: limpeza de ruas para as festividades, pintura de igrejas e edifícios públicos, organizar as festividades, entre outros.

Segundo Candido, um bairro rural pode definir-se como

[...] o agrupamento territorial, mais ou menos denso, cujos limites são traçados pela participação em trabalho de ajuda mútua. É membro do bairro quem convoca e é convocado para tais atividades. A obrigação bilateral é aí elemento integrante da sociabilidade do grupo, que desta forma adquire consciência de unidade e funcionamento [...] A necessidade de ajuda, imposta pela técnica agrícola e a retribuição automática, determinava a formação duma rede ampla de relações, ligando uns aos outros os habitantes do grupo de vizinhança e contribuindo para sua unidade estrutural e funcional [...] Outro elemento de definição da sociabilidade vicinal é a vida lúdico-religiosa - complexo de atividades que

${ }^{87}$. CANDIDO, A., op. cit., 1998, p.57-58, 71-72.

${ }^{88}$. QUEIROZ, M. I. P., op. cit., 1978, p.47-49.

${ }^{89}$. QUEIROZ, M. I. P., op. cit., 1973, p.133. 
transcendem o âmbito familiar, encontrando no bairro a sua unidade básica de manifestação [...] Sob este aspecto poderíamos definir o bairro [...] como o agrupamento mais ou menos denso de vizinhança, cujos limites se definem pela participação de moradores nos festejos religiosos locais. Quer amplos e organizados, geralmente com o apoio na capela consagrada a determinado santo; quer menos formais promovidos em caráter doméstico. Vemos, assim, que o trabalho e a religião se associam para conferir o âmbito e o funcionamento do grupo de vizinhança, cujas moradias, não raro muito afastadas umas das outras, constituem unidade, na medida em que participam no sistema destas atividades. ${ }^{90}$

Outro elemento agregador das relações de vizinhança foi a vida lúdico-religiosa que se manifestava principalmente durante os festejos religiosos. A prática religiosa, independentemente de partir da capela consagrada (nos dizeres do catolicismo oficial) ou da adoração de qualquer santo popular, assegurava a continuidade da sociabilidade vicinal. ${ }^{91}$

Dessa forma, trabalho e religião se associavam "para configurar o âmbito do funcionamento do grupo de vizinhança, cujas moradias, não raro muito afastadas umas das outras, constituem unidade, na medida em que participam no sistema destas atividades."92

De todas as atividades lúdico-religiosas, a procissão era a mais importante e a que melhor representava a alma de um aglomerado. Durante os séculos dezessete e dezoito, a procissão apresentava-se como evento obrigatório para todos os moradores da região. ${ }^{93}$

Para Queiroz, as festas e procissões do bairro rural eram momentos importantes, pois congregavam os camponeses dispersos pelas cercanias, fortaleciam as relações de vizinhança e proporcionavam aos habitantes uma noção de fazer parte do bairro distinguindo-os de outras localidades. Esse "sentimento de localidade constituía elemento básico para delimitar a configuração de um bairro, tanto no espaço geográfico quanto no espaço social". 94

A religiosidade da população era vivamente expressa na reunião que se estabelecia a partir da festa, o que contribuía para o fortalecimento da igreja local e a valorização dos espaços onde essas festas ocorriam. Graças às festas, em aglomerados como a Penha, o urbano passou a ter na religião o fundamento de sua configuração.

Em Sant'Ana também encontramos informações relevantes sobre as procissões e festas religiosas. Segundo este autor, a 17 de janeiro de 1637, o poder constituído

[...] determinara que os moradores mandassem limpar e enramar as ruas por onde passassem a procissão, devendo os oficiais mecânicos levar na dita procissão as

${ }^{90}$. CANDIDO, A., op. cit, 1998, p.67, 68 e 71.

${ }^{91}$. Ibidem, p.67-71.

${ }^{92}$. Ibidem, p.71

93. MARX, Murilo. Nosso Chão: do Sagrado ao Profano. São Paulo: Edusp, 1989, p.61.

${ }^{94}$. QUEIROZ, M. I. P., op. cit., 1973, p.4. 
insígnias de seus ofícios, com pena de dois tostões. [...] Em maio de 1741, por onde passasse a procissão, os moradores deviam ter as ruas limpas e varridas, e as portas e varandas ornadas com colchas ou seda na forma costumada; competindolhes caiar as suas paredes e muros, tapando covas e buracos que tiver a rua junto às suas testadas $[. . .]^{95}$

Como veremos adiante, para as festas da Penha do século dezoito as exigências eram semelhantes.

Na Penha enquanto bairro rural, o campo se apresentava como setor econômico mais forte e era nele que grande parte da população residia. O ritmo de vida era composto por períodos sucessivos de concentração, impulsionado pela festa religiosa ou algum outro momento marcante da vida na localidade, e de dispersão pelas propriedades rurais. Os momentos de dispersão eram bem mais longos que os de concentração. ${ }^{96}$

Segundo Queiroz,

[...] durante o período de dispersão, o contato dos indivíduos reunidos no interior de uma propriedade, ou entorno de uma capela (bairros rurais) era estreito; no caso das fazendas, este contato se fazia entre famílias de camadas diversas, enquanto no caso dos bairros rurais, tinha lugar entre famílias de camadas homogêneas. Nos momentos de concentração nas vilas, fazendeiros e lavradores estabeleciam contatos com gente de seu próprio nível; e os sitiantes dos bairros rurais tomavam conhecimento da variedade de camadas sociais, da variedade de bairros rurais que compunham o universo sócio-econômico da região. ${ }^{97}$

Desta forma, para a autora, o urbano se apresenta como um prolongamento do

rural e os elementos que ditavam as relações sócio-econômicas e culturais associados ao campo acabavam predominando sobre os elementos da cidade.

Em aglomerados como a Penha, nos momentos de concentração as festas envolviam a comunidade por inteiro e apresentavam-se como um desfile de todos para todos, onde as diferenças sociais decodificavam-se na distribuição dos papéis que cada um deveria representar no evento.

Queiroz afirma que durante o período colonial não existia diferença clara entre campo e cidade e sugere que para o entendimento dessa relação é muito importante ter ciência que

[...] a cidade não se confunde com o campo, na colônia luso-brasileira; o homem de cor livre não se confunde com o branco; a civilização ocidental não se confunde nem com a africana, nem com a aborígine. Porém tudo isto se interpenetra, sem divisões irrecorríveis entre etnias, entre civilizações, entre campo e cidade. O comportamento varia conforme esteja no campo ou na cidade, mas sempre ele pertence a duas realidades. ${ }^{98}$

\footnotetext{
95. SANT'ANA, Nuto. Festas religiosas e profanas. In: Ensaios Paulistas. São Paulo: editora Anhambi S/A, 1958, p. 442-443.

${ }^{96}$. QUEIROZ, M. I. P., op. cit., 1978, p. 270.

${ }^{97}$. Ibidem, p.280. Segundo a autora: "a cidade era um prolongamento das fazendas, existindo para servi-las e não para dominá-las.”

${ }^{98}$. Ibidem, p.280-281.
} 
Voltando ao fator religiosidade, enquanto centralizadora das relações sociais no bairro rural, podemos observar que a capela apresenta-se como referência desde a origem do espaço penhense.

Na capela de Nossa Senhora da Penha de França se encontrava o conforto espiritual e em sua volta se desenvolvia um pequeno comércio (onde os sitiantes compravam aqueles produtos que não podiam produzir no interior de suas terras e vendiam os excedentes do que produziam) e alguns serviços para viajantes (relacionados com o pouso dos mesmos e de seus animais e até mesmo dos sitiantes da região) que garantiam o mínimo conforto material. ${ }^{99}$

Ao longo de quase todo o século dezenove, a paisagem da freguesia pouco se alterou do que foi mencionado no parágrafo anterior. Manteve a mesma forma: uma capela arrodeada de poucas casas humildes algumas vendas e alguns serviços. Para além do pequeno núcleo estendiam-se lavouras e pastagens.

Bruno, com grande propriedade, retrata em detalhe como seria a paisagem de São Paulo no período colonial e, que, podemos crer, repetia-se no bairro da Penha:

A casa piratininga durante os tempos coloniais parece que não era feita para durar muito. E isso acontecia não apenas com as edificações das eras primitivas, feitas de paus roliços e de teto de palha - muitas vêzes para moradia de índios - por padres jesuítas improvisados em mestres de obra, mas também com aquelas outras feitas de taipa e cobertas de telha, não raro assobradadas, que representavam a partir de fins quinhentistas em tipo de construção na vila. Destas últimas muitas pertenciam a fazendeiros que moravam na roça se utilizavam delas apenas em ocasião de festa. Nos outros dias elas ficavam de portas melancòlicamente trancadas - na sonolência da povoação quase deserta - a fôlha das janelas lavada pelas chuvas ou torrada pelo sol [...] As próprias igrejas e os próprios conventos, embora fossem construções mais importantes da vila, não passavam muitos anos sem que sofressem alguma reforma por dentro e por fora, alguma remodelação de fachada ou até alguma reedificação completa. ${ }^{100}$

Poucas eram as casas construídas com tijolos cozidos e que apresentavam telhado de cerâmica. Geralmente a arquitetura era grosseira e a falta de mão-de-obra mais especializada rendia construções de aparência desagradável. ${ }^{101}$ Somente a partir de meados do século dezessete, devido ao acúmulo de riqueza de alguns que negociavam escravos, é que apareceram habitações ostentando maiores dimensões e conforto. ${ }^{102} \mathrm{Se}$ isso era raro na vila de São Paulo, imagine em bairros como a Penha.

\footnotetext{
99. SANTARCANGELO, M. C. V., op. cit., 1968, p.5-15

100 . BRUNO, E. S., op. cit., 1984, p.99-100.

101 . Ibidem, p.103-105.

102 . Ibidem, p.116.
} 


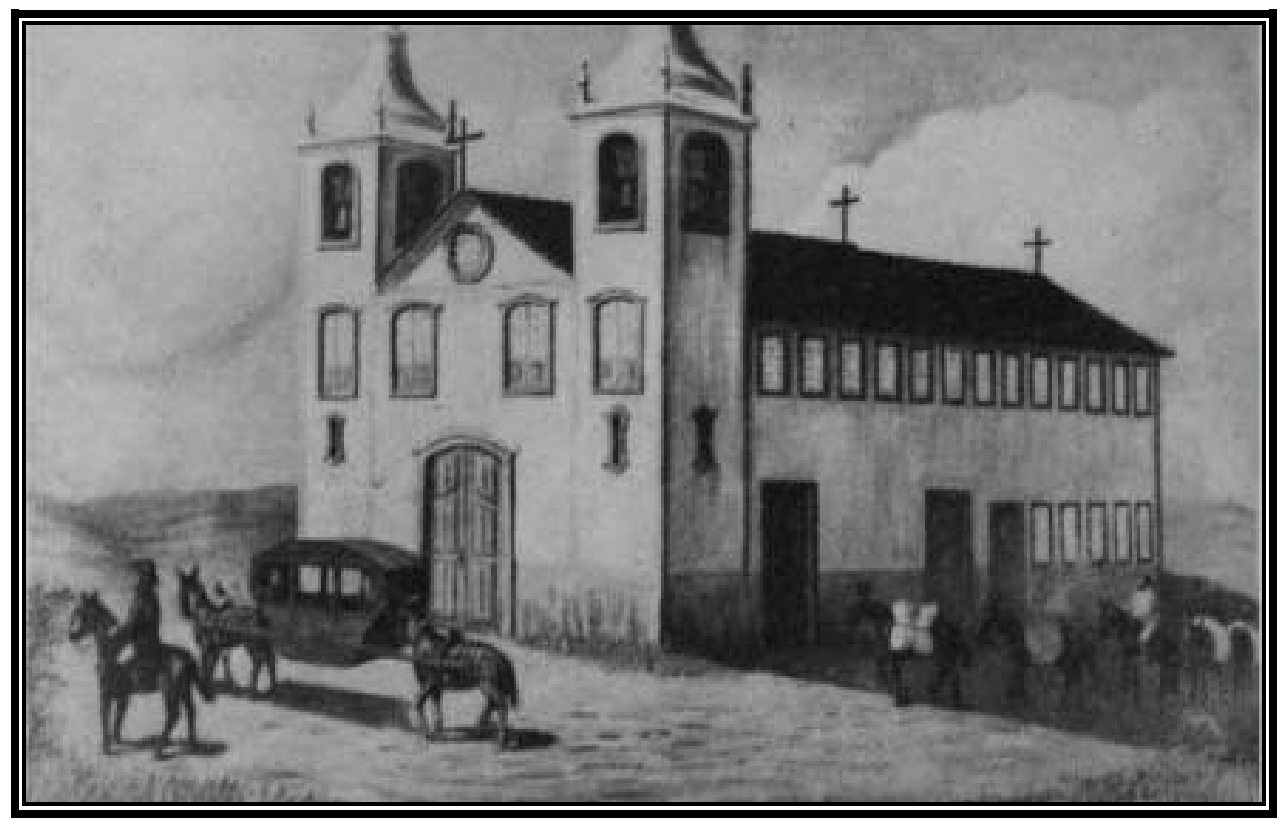

Liteira em à frente Igreja da Penha no século dezessete. Quadro de Adelaide Cavalcante do acervo do Museu Paulista (Memorial da Penha de França, acervo digitalizado) ${ }^{103}$

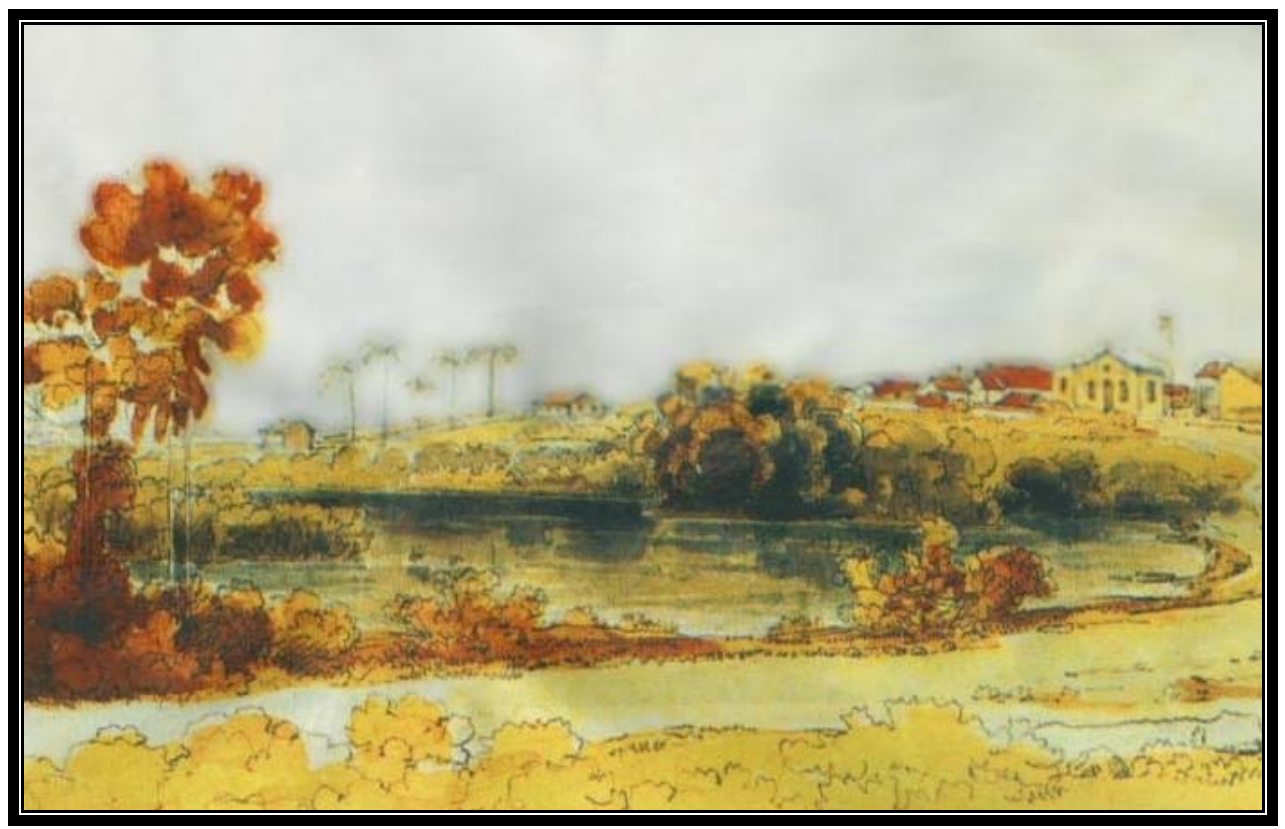

Vista da colina da Penha em 1817, o rio em primeiro plano é o Aricanduva. Quadro de Thomas Ender. (Memorial da Penha de França, acervo digitalizado)

As igrejas seguiam os mesmos padrões de construção e poucas possuíam torres de pedra como as européias. Segundo Bruno, as igrejas brasileiras do período colonial geralmente eram "pesadonas e de fachadas sóbrias [...] A riqueza dêsses templos estava às vezes nas decorações do seu interior. A pobreza de recursos, sobretudo em São Paulo,

${ }^{103}$. RETRATOS DA PENHA. Memorial Penha de França. $3^{\mathrm{a}}$ edição, São Paulo, 2004. CD ROM. Todas as imagens digitalizadas utilizadas no trabalho são do mesmo acervo. 
não teria mesmo permitido nesse tempo fachadas mais ricas ou mais trabalhadas artisticamente." 104

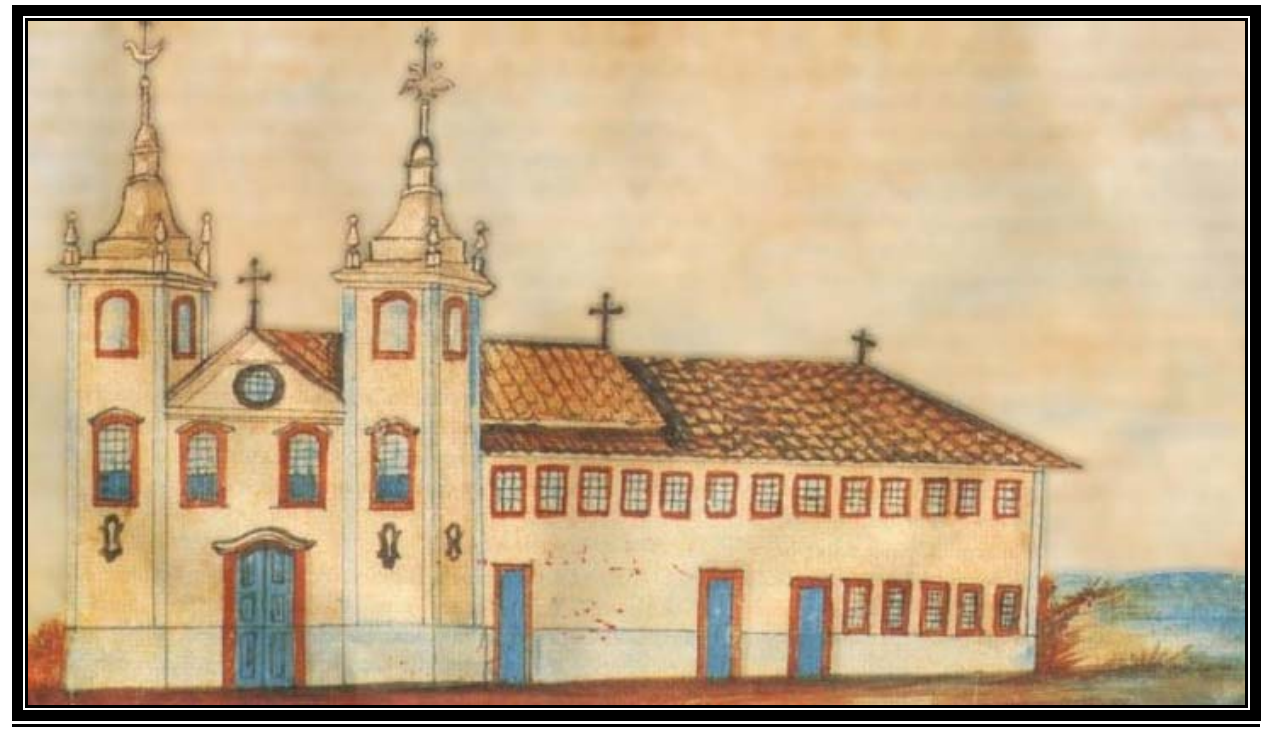

Igreja Nossa Senhora da Penha no século dezenove. Aquarela de Miguel Dutra do acervo do Museu Republicano de Itu (Memorial da Penha de França, acervo digitalizado)

A taipa de pilão era o sistema de construção dominante e a maioria das casas e igrejas eram de um pavimento só. Em frente a elas predominavam ruas e pátios esburacados, com sarjetas mal delineadas e com muito mato, sujeiras de animais e lama em dias de chuva. No cair das noites sem lua reinava um breu profundo. ${ }^{105}$ Tudo só se alterava em período de festa.

A festa era o momento em que os vizinhos se encontravam e reforçavam suas relações, em que se uniam para a limpeza e a decoração das casas e ruas.

No Brasil, a diferença entre campo e cidade somente começou a se aprofundar com a chegada da Família Real no Rio de Janeiro em 1808. Junto com a Corte se estabeleceu uma população que nada tinha em comum com o campo e a cidade lentamente passou a ter um valor diferenciado. Viver na cidade era estar junto à Corte, era estar com os poderosos. Segundo Queiroz,

[...] foi a partir desse momento que um novo ritmo de vida iniciou seu processo, segundo o qual se passava mais tempo na cidade e períodos mais curtos de férias na fazenda; lentamente, foram se separando populações urbanas e populações rurais, mostrando que se penetrara numa nova era, na era em que a cidade tinha vida por si mesma, e tendia a se tornar predominante em relação ao campo. ${ }^{106}$

Em 1822, com a Independência do Brasil, houve rápido fortalecimento das atividades públicas administrativas. A capital federal e as capitais de província adquiriram

${ }^{104}$. BRUNO, E. S., op. cit., 1984, p.115-116.

${ }^{105}$. Ibidem, p.159.

${ }^{106}$. QUEIROZ, M. I. P., op. cit., 1978, p.281. 
nova importância e confirmaram sua centralidade, ou seja, a cidade confirmou sua centralidade e os habitantes urbanos passaram a desenvolver tarefas exclusivamente urbanas.

Segundo Martin, os movimentos de independência, inspirados nos ideais da Revolução Francesa e pelo grande esforço de “ajustamento a nova ordem econômica mundial” determinada pela Inglaterra e pela livre-concorrência, trouxeram consigo os estímulos às mudanças. No caso do Brasil, o autor afirma que a estagnação econômica “marcada pelo declínio da mineração e pela permanência de uma corte parasitária que penalizava ainda mais a já combalida economia da Colônia”, gerou uma crise que só foi superada quando a economia cafeeira passou a se desenvolver. ${ }^{107}$

Segundo este autor, após a Independência, a terra e o trabalho escravo ainda eram as molas propulsoras da economia, no entanto, a produção do café trazia consigo significativas inovações: a) produzir café era mais barato que produzir açúcar, permitia maior acumulação; b) “na cafeicultura os interesses de produtores e comerciantes estavam desde logo entrelaçados, uma vez que não se contava mais com a mediação de uma Metrópole, podendo a comercialização de produtos tropicais para a Europa e agora também para os Estados Unidos realizar-se diretamente.”108

Segundo Martin, a Independência política trouxe como fato positivo o processo de urbanização: as cidades, principalmente as capitais das províncias, tornaram-se referências importantes para a economia cafeicultora. Nelas houve a necessidade de se desenvolver um aparato burocrático mais eficiente, aprimorar os serviços e, com o deslocamento dos grandes cafeicultores da zona rural para as urbanas, novos requintes arquitetônicos e urbanísticos passaram a se desenvolver. ${ }^{109}$

No entanto, Martin afirma que a maioria dos núcleos urbanos distantes dos portos ou fora da rota do café se mantiveram estagnados e com “aspecto tosco.”"110

Segundo Queiroz, neste momento histórico campo e cidade pouco a pouco passaram a se apresentar como complementares, compondo uma totalidade real. ${ }^{111}$

O fortalecimento da cidade trouxe consigo a valorização da maneira de viver urbana e tal processo não deixaria a Penha do lado de fora. E foi justamente a partir das festas e procissões, referências culturais do bairro rural, que o modo de viver da cidade

107. MARTIN, A. R., op. cit., 1984, p.11-12.

108 . Ibidem, p.12.

109 . Idem.

${ }^{110}$. Idem.

${ }^{111}$. QUEIROZ, M. I. P., op. cit., 1978, p.274-281. 
passou a modificar as antigas formas de relacionamento e de viver do bairro rural. As festas e procissões aproximaram a Penha da cidade de São Paulo e, na mesma proporção, fragilizaram as relações sociais locais.

\subsection{Algumas considerações sobre o catolicismo na organização do espaço brasileiro}

Na história do Brasil e consequentemente da Penha, a Igreja Católica, com suas práticas, símbolos, discursos e ações, se apresentaram como importante instituição no processo de construção do espaço. Desta feita, pela própria história da Penha, se quisermos entender sua configuração espacial, nada mais correto que partirmos da compreensão da história do catolicismo em solo brasileiro. E esta, começa pelo que foi identificado como "catolicismo popular” ou, como muitos autores preferem, “catolicismo rústico”. 112

Os estudos sobre as relações sócio-culturais no espaço penhense, mostram que o catolicismo popular, e não poderia ser de outra forma, aparece marcante e se manteve firme enquanto o aglomerado se apresentou como apêndice do campo. No entanto, antes de identificarmos as formas deste catolicismo no bairro, vamos delinear algumas das características históricas da Igreja Católica no território brasileiro.

Segundo Guimarães, a ação da Igreja Católica se apresentou ora de caráter institucional, hierarquicamente organizada, buscando criar uma unidade coerente por meio de normas, regulamentos e padrões definidores dos modos de viver e de ser no mundo terreno; ora “detentora, formadora e precursora de valores, hábitos, costumes e comportamentos que buscam uma sincronia ou não entre o sobrenatural $e$ o transcendente, o racional e o temporal [...] carregada de sentidos, representações $e$ simbologias [...]" e "portadora de dogmas, doutrinas, conceitos e preconceitos em que estão presentes categorias como fé e razão, transcendência e imanência, filosofia e ideologia, matéria e espírito, teologia e política, ética e moral," em que "fé e razão misturam-se, entrelaçam-se e ou assumem pólos opostos, divergentes, antagônicos e irreconciliáveis, já que a fé pode adotar e adquirir uma riqueza supra-racional ao se proclamar acima de todos os valores," ora como instituição social, "estabelecendo relações e vínculos com os indivíduos, grupos, classes sociais e o Estado.” Nesses

112 . Devido à abrangência da literatura utilizada para explicar essa forma de manifestação histórica do catolicismo brasileiro, utilizarei indiscriminadamente ambos os termos. 
parâmetros, a relação sociedade-Igreja apresentou-se “dinâmica e dialética, influenciando-se e constituindo-se mutuamente. "113

Até meados do século dezenove essas ações se estruturavam no espaço brasileiro intermediadas pela atuação de duas forças complementares: o poder temporal, caracterizado pelas ordenanças da Coroa, e o poder canônico, responsável pela cobrança dos forais, a doutrinação e a assistência espiritual.

Segundo Bôa Nova:

Na primeira etapa do Período Colonial - a Conquista - o poder metropolitano pouco se faz sentir diretamente. Na verdade a ação principal coube à simples iniciativa individual, promovida por pessoas de posses relativamente modestas, que organizavam grupos de indivíduos interessados na partilha dos frutos da pilhagem. O verdadeiro mentor da ação que, viria a estruturar o novo império seria o interesse privado do conquistador. Ao lado deste, o missionário é figura de destaque. As primeiras missões são empreendidas pelas ordens religiosas e levadas adiante graças ao arrojo de indivíduos radicalmente devotados às causas católicas. ${ }^{114}$

Assim, a Igreja aparecia e procurava estabelecer uma ordem mínima, nem tanto político-administrativa, mas pelo menos social, aos espaços que eram conquistados.

Nesse contexto, religiosos e aventureiros dividiam os méritos da luta pela conquista do espaço brasileiro. Ambos, com seus santos protetores, rompiam as matas e criavam trilhas, aldeamentos e pequenos aglomerados para a metrópole portuguesa.

Ainda segundo Bôa Nova, na fase da Conquista, primeira etapa do período colonial, o casamento entre a Igreja e a Coroa efetivava-se harmoniosamente e nas capelas onde esses poderes se encontravam menos efetivos, onde o clero regular (representante oficial da Igreja) se encontrava ausente estabelecia-se o regime de padroado. Muito comum na Europa, o padroado se apresentava como o mecanismo que conferia a um soberano laico o status de detentor, na ação prática, do poder religioso em seus domínios. Em certos casos, a este soberano eram conferidas posturas como nomeação de bispos e párocos, escolha dos locais onde deveriam ser ministrados cultos e até demarcação dos limites de uma diocese. ${ }^{115}$

Nos pequenos aglomerados rurais como a Penha, o regime de padroado formavase e fortalecia-se nas relações sociais estabelecidas a partir da identificação entre seus moradores, ou seja, surgia das relações familiares, das relações de trabalho e do sentimento religioso.

113. GUIMARÃES, Simone de Jesus. Serviço Social e Igreja Católica no Brasil Pós Ditadura. São Paulo: Tese de doutoramento apresentada à Pontifícia Universidade Católica de São Paulo, na área de Serviço Social, 1998, p.44-45.

${ }^{114}$. BÔA NOVA, Antonio Carlos. Clero e Povo. São Paulo: CERU e FFLCH/USP, 1981, p.34.

${ }^{115}$. Ibidem, p.34-36 
Era fato comum nos aglomerados rurais brasileiros da fase da Conquista ver emergir naturalmente das relações de vizinhança uma liderança religiosa leiga responsável pela precária implementação de regras e ritos associados ao catolicismo popular. ${ }^{116}$ Na Penha, quem assumiu tal papel foi o “padre” Jacinto Nunes de Siqueira.

Assim, não seria descabido supor que Padre Jacinto Nunes de Siqueira tivesse tal papel por que: a) no século dezesseis, eram raros os padres que circulavam ou se fixavam em paragens como a Penha e, segundo, porque seu pai, o licenciado Mateus Nunes de Siqueira, já era filho e neto de um povoador, cremos que o Padre Jacinto fora criado e instruído aqui, portanto longe de qualquer ordenança oficial; b) as dificuldades de deslocamentos e a precariedade da estrutura econômica dos sesmeiros paulistas, que viviam da subsistência, do simples escambo e de rendimentos baixos, impediam-nos de buscar instruções canônicas na metrópole.

De início, os pequenos aglomerados apresentavam-se dotados de inúmeros símbolos católicos: eram elementos decorativos, como imagens e cruzes, que se espalhavam pelo espaço fortalecendo diariamente os valores dominantes. Somente com o passar do tempo, os símbolos laicos (como pontes, chafarizes e outros monumentos públicos) chegavam e se estabeleciam. ${ }^{117}$

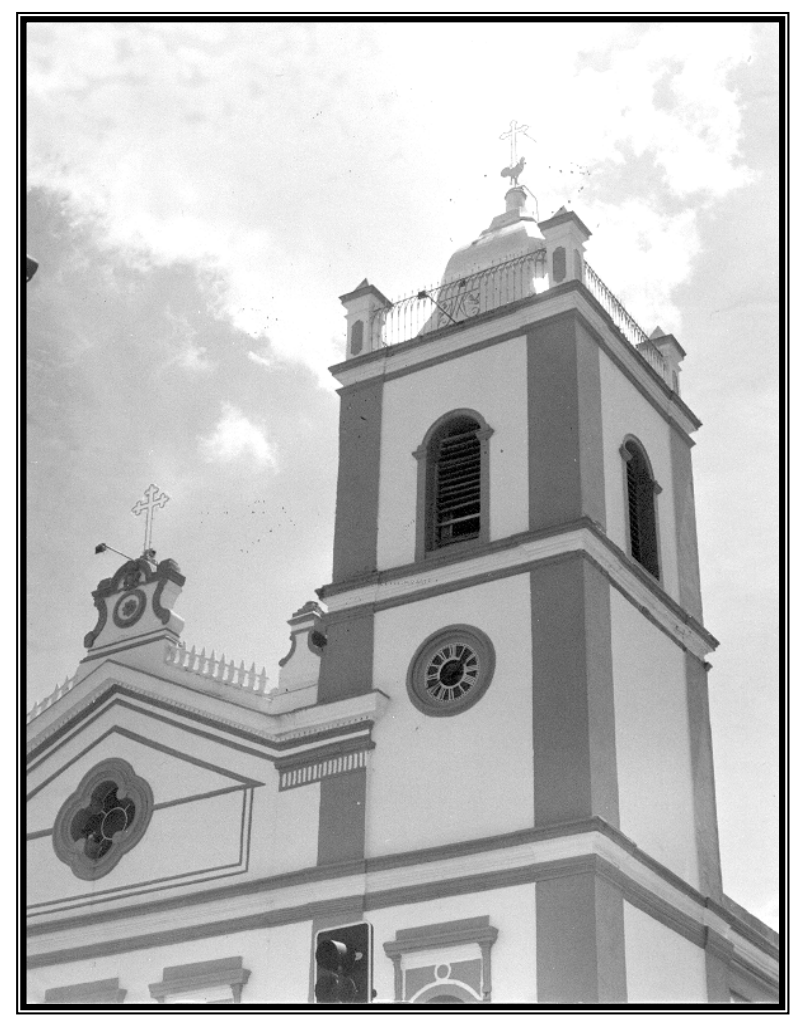

Antiga Igreja de Nossa Senhora da Penha No alto de sua torre símbolos do catolicismo, o galo e a cruz. (Foto Edson Penha de Jesus - 2002)

\footnotetext{
116 . Ibidem, p.23-24.

117. MARX, Murillo. Nosso Chão: do sagrado ao profano. São Paulo: Editora da Universidade de São Paulo, 1988, p.158.
} 
A vida coletiva nessas sociedades encontrava-se amarrada a severos preceitos morais cristãos que garantiam a unidade e, como já foi citado, só se estabeleciam mediante a presença de uma liderança persuasiva. Essa liderança necessitava apresentar a respeitosa capacidade de evocações divinas, com a comunicação aberta para levar aos demais as recomendações das entidades sobrenaturais (santo padroeiro e demais santos, finados importantes, anjos etc.). ${ }^{118}$

Assim, a partir do santo padroeiro e de sua liderança na terra estabelecia-se a rotina dos pequenos aglomerados do período colonial: o calendário da localidade associava o tempo do plantio, o período das chuvas, o tempo da colheita, à festa do padroeiro, à procissão, entre outros. ${ }^{119}$

As relações entre religião e povo não ocorriam aleatoriamente. Para tanto, era necessário que antes fosse estabelecido um conjunto de regras fortalecidas no âmbito das precárias associações católicas, organizações compostas por representantes das famílias do aglomerado.

\section{Segundo Bôa Nova}

[...] a experiência religiosa vivida no interior das pessoas traduz-se em crenças intelectuais e em atos. Estes, por sua vez, são compartilhados socialmente, em doutrinas e ritos. Têm-se aí os três aspectos básicos da expressão religiosa: o teórico (doutrina), o prático (culto) e o social (a comunhão de idéias e atos religiosos) [...] enquanto os mitos, doutrinas e ritos são produtos da atividade cultural, as associações religiosas representam organizações da sociedade humana. Entretanto, os elementos doutrinais e rituais encerram enorme relevância [...] quando considerados à luz das condições sociais de sua origem, divulgação e consolidação. ${ }^{120}$

Desta forma, a vida da comunidade se apresentava muito mais relacionada ao padroeiro que ao próprio Deus católico, uma vez que toda a atividade cultural da sociedade estava condicionada à fé no padroeiro escolhido. Essa legitimação do santo e todo o conjunto de ritos criados para ele, de acordo com os interesses imediatos da comunidade, apresenta-se como cerne do catolicismo popular.

Bôa Nova enriquece a discussão assinalando que "o Catolicismo Popular LatinoAmericano foi marcado pela presença do sincretismo, ou seja, a fusão de traços provenientes de sistemas culturais distintos, embora permaneçam visíveis alguns sinais das respectivas origens. "121 Importante ressaltar que essa fusão não era exclusividade da América Latina. Para o autor, “esse sincretismo já existia no próprio Catolicismo Popular Ibérico,” e foi apenas transplantado para as colônias e “suas origens remontam

${ }^{118}$. BÔA NOVA, A. C., op. cit., 1981, p.52-53.

119. CANDIDO, A., op. cit, 1998, p.67, 68 e 72.

${ }^{120}$. BÔA NOVA, A. C., op. cit., 1981, p.23.

${ }^{121}$. Ibidem, p.57. 
ao processo de conversão dos povos bárbaros, com reinterpretação de ritos e crenças do paganismo." 122

Nas colônias esse sincretismo caracterizou-se pela integração das práticas religiosas adaptadas aos interesses e aspectos culturais das coletividades que se formavam.

Podemos dizer que o catolicismo popular apresentava-se como um conjunto de práticas e representações que associavam a relação clerical tradicional à conduta empírica individual de seus praticantes. Para Oliveira, o Catolicismo Popular seria

[...] o conjunto de representações e práticas religiosas dos católicos que não dependem da intervenção da autoridade eclesiástica para serem adotadas pelos fiéis. Concretamente, chamamos de Catolicismo Popular as representações e práticas relativas ao culto dos santos e à transação com a natureza e não os sacramentos e a catequese formal. ${ }^{123}$

No catolicismo popular, os santos apresentam-se como entidades sobrenaturais superiores e ao mesmo tempo seres pessoais capazes de intervir diretamente nas relações entre os homens e Deus. Os santos são capazes de dar proteção e realizar os desejos de seu seguidor em troca do mais diferenciado tipo de penitência.

Esses santos apresentam-se como heróis possuidores de glórias em suas vidas terrenas e que após a morte tornaram-se lendários e dignos de devoção, portanto capazes de conceder graças e proteção a quem lhes dedicar cultos ou os invocar como proteção.

No catolicismo popular, qualquer um poderia tornar-se santo para devoção. Na prática do sincretismo havia uma multidão de santos, muitos reconhecidos pela Igreja e outros, inventados e reconhecidos apenas em pequenas comunidades. Muitas vezes tinham efêmero período de devoção, sendo cultuados por apenas algumas gerações.

Segundo Oliveira,

[...] a presença do santo como imagem é importante para o Catolicismo Popular, porque ele torna possível o contato direto do fiel e o santo. Os santos estão por assim dizer, ao alcance de qualquer fiel, sem que intervenha alguma mediação institucional entre eles. Esse domínio prático do culto por todos os fiéis, em conjunto ou individualmente, independentemente de sua qualificação institucional, é uma das características principais do catolicismo popular. ${ }^{124}$

Assim, a relação entre o fiel e o santo apresentava-se cômoda e direta: cômoda, porque não lhe exigia dedicação para com a Igreja bastando-lhe apenas um pequeno altar em casa para adoração; direta, pois tornava a presença do clero regular supérflua.

O catolicismo popular costumava ser praticado com mais freqüência no meio rural que no meio urbano e não fazia qualquer restrição se o homem fosse branco, negro, índio

${ }^{122}$. Idem.

123. OLIVEIRA, Pedro A. Ribeiro de. Religião e Dominação de Classe: gênese estrutura e função do Catolicismo Romanizado no Brasil. São Paulo: Vozes, 1985, p.113. 
ou mestiço. Como exemplo, temos o sincretismo desenvolvido pelos escravos que geralmente resgatavam suas divindades africanas e praticavam seus ritos associados à religião do senhorio nos terreiros das fazendas e nos adros das capelas. No entanto, o catolicismo praticado pelos negros não ocorria no mesmo espaço que o praticado pelos brancos.

Na Penha, por exemplo, os negros eram agrupados em uma associação, a Irmandade dos Homens Pretos da Freguesia da Penha de França e a partir de 16 de julho de 1808, passaram a ter seu próprio espaço de devoção: a capela de Nossa Senhora dos Homens Pretos, localizada no Largo do Rosário, hoje conhecida por Igreja do Rosário.

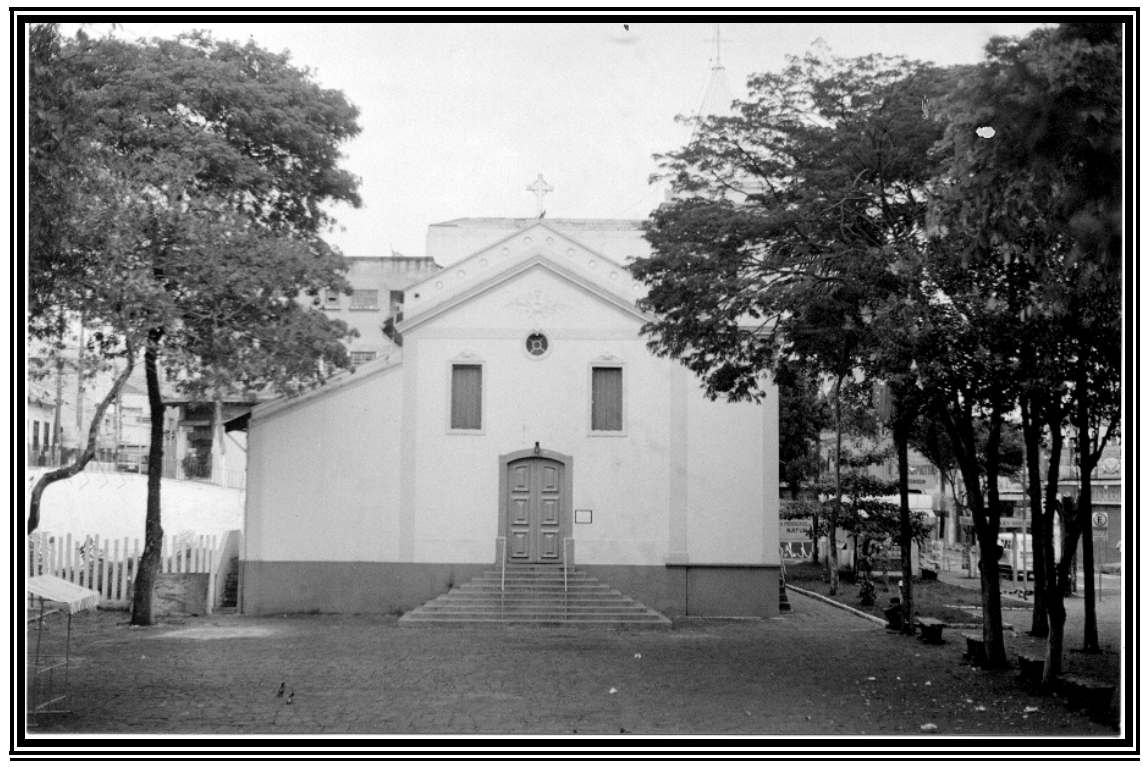

Igreja do Rosário - Inaugurada em 1808 (Foto Edson Penha de Jesus, 2002)

Faz se necessário aqui um adendo para explicar de onde vem a iniciativa de se idealizar esses espaços de reprodução da cultura negra. Segundo Morse,

[...] os cerimoniais negros constituíam um encravamento na cultura colonial básica. Nos tempos coloniais, a agitação e as propaladas imoralidades que os acompanhavam provocavam interdição por parte das autoridades da cidade. Continuavam eles a realizar-se todavia, alguns clandestinamente, outros abertamente [...] No comêço do século XIX suspendeu-se a proibição, e as danças foram permitidas mediante a pagamento de licença. A mais importante de tôdas era a que se realizava em honra da padroeira dos homens pretos, Nossa Senhora do Rosário. Depois de um ofício religioso, os negros, com vestes coloridas, reuniam-se em frente à igreja dedicada à padroeira, para uma dança animada. $[\ldots]^{125}$

Assim, a criação de espaços como a Igreja do Rosário foi a medida encontrada para resolver um problema que começava a escapar do controle do poder canônico.

Cabe observar que o catolicismo popular apresentava-se como devoção muito mais individualizada e simbolizada em pequenos altares dentro das casas ou nos quintais

${ }^{124}$. Ibidem, p.115. 
do que coletivizada em capelas e não favorecia a concentração humana em torno das capelas que surgiam. As capelas tornavam-se atrativas apenas durante as festividades e tal rotina comprometia diretamente o crescimento dos aglomerados localizados nas zonas rurais. O crescimento do aglomerado penhense é um exemplo disso, pois pouco se desenvolveu de sua origem até o final do século dezenove.

Para melhor entendimento da relação entre o devoto e o santo, Oliveira procura esclarecer que entre ambos existia um “contrato” pelo qual o devoto via-se obrigado a recompensar o santo pela graça alcançada. O pagamento tinha sua forma típica: a promessa.

Segundo Oliveira, a promessa

[...] é coisa séria. Não se faz uma promessa à toa, nem se pode deixar de pagar uma promessa. Para graças miúdas não se faz promessa; simplesmente, pede-se a graça ao santo de sua preferência e, uma vez recebida, oferece-se ao santo algum ato de culto. Outra forma do modo contratual é a novena. Neste caso quem deseja receber a graça faz o ato de culto, ficando o santo na posição de devedor até a graça ser alcançada. ${ }^{126}$

A novena em busca de graças é especial e não se apresenta muito diferenciada da novena de festa, sendo que esta segunda era caracterizada pela homenagem ao padroeiro ou à padroeira.

Oliveira relata ainda que havia diversos tipos de novenas, como por exemplo

[...] a novena para pedir chuva: o santo que não faz chover quando termina a novena pode até receber castigo. Em suma: $\mathrm{O}$ modo contratual de relações entre fiel e o santo pode ser caracterizado pelo contrato moral entre eles; o fiel se compromete a realizar um ato de culto considerado equivalente à graça recebida ou por receber. Recebida a graça e paga a promessa, o fiel está quite com o santo, podendo voltar a recorrer a ele ou não. ${ }^{127}$

Conclusão, se o santo não correspondesse aos pedidos, caía no descrédito e começava lentamente a ser substituído por outro.

Como veremos na Penha do século dezenove, a procissão à padroeira vai se destacar como a principal forma de pagamento “ou cobrança” destes acordos e, pela sobrevivência da santa ao longo de tantos séculos, podemos supor que ela nunca deixou de atender seus seguidores.

O aumento da veneração e da importância do santo resultava em interessantes alterações sócio-espaciais. A capela do aglomerado uma vez alcançando certo destaque religioso partia em busca da oficialização. Não bastava apenas vontade, era necessário garantir que a sobrevivência da capela era possível. Uma vez confirmada tal possibilidade, a capela era curada e recebia seu patrimônio religioso.

125. MORSE, R. M., op. cit., 1970, p.64-65.

${ }^{126}$. OLIVEIRA, P. A. R. de, op. cit., 1985, p.117. 
Segundo Murillo Marx, assim que a capela era reconhecida, era conferida nova qualificação ao lugarejo e desta forma,

[...] naquela determinada localidade, especificamente sob aquele determinado teto, os sacramentos poderiam ser ministrados e, particularmente, ser rezada a missa. O chão sob humilde cobertura, a partir da ereção e só a partir de então, passava a ser sagrado, considerado e respeitado obrigatoriamente como tal. ${ }^{128}$

O aglomerado elevado à categoria de arraial tinha sua paisagem modificada de imediato, começando pela construção de uma nova capela que, de antemão, deveria ocupar o melhor e mais elevado local ${ }^{129}$, apresentar uma arquitetura menos rústica e ter sua entrada voltada para sua catedral matriz, a Sé.

A capela deveria apresentar uma aparência mais digna para proporcionar-lhe o status de matriz (a mais importante da região) e junto à mesma levanta-se a sacristia e a casa para abrigar os religiosos. Os gastos de tal reforma eram conferidos aos sesmeiros e demais moradores da localidade. ${ }^{130}$

Com o novo desígnio, tornava-se necessário definir os locais pios do aglomerado. Como locais pios, além da igreja e dos edifícios a ela acoplados, eram definidas as áreas do adro, as áreas laterais e as localizadas ao fundo da capela. Estes espaços deveriam se apresentar bem amplos, pois eram reservados para diversas práticas religiosas. Tais espaços deveriam se apresentar suficientes para atender a circulação dos devotos, dos negociantes e meios de transportes. O fundo tinha designação especial: era reservado para a possível instalação do cemitério. ${ }^{131}$

Importante destacar que ainda não havia separação entre o adro e as vias de circulação, ambos eram um único equipamento e não havia qualquer delimitação clara entre o espaço considerado sagrado e o espaço de uso público. O patrimônio era da Igreja e não do Estado.

As demais áreas do patrimônio religioso eram destinadas ao aforamento (sendo a capela beneficiária de tal tributo) e ao uso comunal, para extração de madeiras, cultivos, pastos, para construção de moradia, negócios entre outros. Para a igreja local, era importante que esses espaços fossem ocupados.

127 . Ibidem, p.113.

${ }^{128}$. MARX, M., op. cit., 1991, p.20. Segundo Murillo Marx, a legislação sobre a ereção de ermidas e capelas curadas é encontrada nas constituições 683, 868 e 1279 das Constituiçõens Primeyras do Arcebispado da Bahia, regidas em 1707 e publicadas em 1719.

129. MARX, M., op. cit., 1988, p.31.

${ }^{130}$. Ibidem, p.116.

131. Ibidem, p.119. Segundo o autor, este cemitério era destinado àqueles que participassem de alguma irmandade em vida e "fora de tais necrópoles ficavam apenas os que estão à margem ou muito embaixo da ordem social, como os não-católicos, os malfeitores, os escravo Para eles apareceram nossos poucos e primeiros cemitérios". 
No patrimônio religioso, a Igreja assumia a responsabilidade de organizar o espaço. Seu papel começava pela escolha da localização, da orientação do templo e da disposição de seu adro, do posicionamento dos edifícios a seu redor, da definição dos espaços a serem ocupados pelo uso comunal, e, por fim, pelo condicionamento do uso de ruas e largos. Somando-se a esses, ainda havia o "estrito controle sobre as datas, os horários, a duração e as maneiras detalhadas para se organizarem e fazerem as procissões”, como também sobre “o emprego das imagens dos santos e, sobretudo, da cruz. ${ }^{\prime 132}$

Essas mudanças, mesmo que precárias, fortaleciam a Igreja, enquanto referência e definiam de vez o que e quem era o centro da região. Em tal centralidade, a religiosidade definia a concepção do tempo e o ritmo da vida a partir da reza e do sino. Assim, o tempo da reza, marca importante do catolicismo popular, e o badalo do sino estabeleciam a prática social e o viés ideológico da vida de bairro.

Quando o arraial alcançava certo desenvolvimento demográfico passava a aspirar um reconhecimento institucional de maior importância do que o de apenas capela curada, podendo solicitar o status de freguesia. Para alcançar esse novo patamar, não bastava somente ter aumentado sua população, era preciso também apresentar forte ocorrência de fiéis. Segundo Murilo Marx,

[...] por meio da elevação da categoria de sua simples capela ou capela curada a outro patamar, patamar antes de tudo de cunho religioso, já agora, contudo, eivado de um cunho civil explícito hoje menosprezado: a ereção do lugarejo, da 'capela', em paróquia, cujo nome corriqueiro tradicional de freguesia que constituía o módulo da organização eclesiástica, como que a sua unidade territorial. No entanto com implicações diretas de compromisso com o Estado [...] tão decisivas quanto arrolar e arquivar os dados relativos à vida da comunidade, das famílias, de cada um. ${ }^{133}$

Pelo que foi pesquisado, a Penha foi elevada à categoria de freguesia, porém, por jurisprudência, desempenhava o papel de paróquia.

A Penha deixou de ser um arraial em 15 de setembro de 1796 quando, segundo Bontempi, foi elevada à categoria de freguesia ${ }^{134}$ e segundo Arroyo, à categoria de paróquia. ${ }^{135}$ Essa mudança se justificava não pelo desenvolvimento econômico e sim pelo desenvolvimento religioso da localidade, a fama da santa milagreira ecoava pelos arredores.

132 . Ibidem, p.32.

133 . MARX, M., op. cit., 1991, p.26-27.

134 . BONTEMPI, S., op. cit., 1969, p.37-38.

135 . ARROYO, L., op. cit., 1954, p.175-176. 
Nesse período, a paisagem da freguesia de Nossa Senhora da Penha ${ }^{136}$ era constituída de um agrupamento de casas humildes em torno de sua capela e de algumas vendas onde se encontravam especiarias e utensílios domésticos. Lavouras e pastagens cercavam o aglomerado. O crescente tradicionalismo religioso já lhe rendia alguns frutos.

Em termos de território, freguesia e paróquia possuíam os mesmos limites, a diferenciação estava no nível das atribuições administrativas que cabiam a uma e a outra. Na freguesia, apenas o controle religioso, enquanto na paróquia, além deste, somavam-se algumas funções administrativas que cabiam ao Estado, como por exemplo, funções educativas, serviços de registro civil (registros de nascimento, atestados de óbitos) entre outros. Segundo Santos, na paróquia

[...] destacava-se o papel a ser cumprido na educação dos habitantes, que residiam em seus territórios, com a difusão através das matrizes e capelas do ideário religioso católico, principal sustentáculo ideológico da estrutura econômica, social e política implantada pela metrópole na colônia. ${ }^{137}$

Com o estabelecimento da freguesia, a vida dos moradores se impregnaria ainda mais de representações e referências simbólicas sagradas. A partir deste momento, um clérigo regular fixo passou a celebrar a missa e não mais um que aparecesse esporadicamente ou, na ausência deste, um leigo. De imediato, o catolicismo popular até poderia aparentar estar enfraquecido, mas acreditamos que isso acabava ficando quase que restrito à diminuição de sua influência sobre a organização do espaço. A nova condição política do aglomerado pouco alterou as concepções religiosas do imaginário popular.

O estabelecimento da freguesia no final do século dezoito representou a chegada da ordem distante o que por si só não representou grandes alterações no modo de vida. Acreditamos que tal realidade sobreviveu até meados do século dezenove.

As próximas páginas serão dedicadas a argumentação da hipótese levantada no parágrafo anterior.

\subsection{A procissão de Nossa senhora da Penha: fator de aproximação do bairro rural da} Penha com a capital.

\footnotetext{
136. A extensão administrativa da freguesia de Nossa Senhora da Penha era muito vasta e incluía áreas hoje conhecidas como São Miguel Paulista, Itaquera, Guaianazes, entre outras. Podemos verificar isso nos relatórios de visitas dos padres, parte dos registros paroquiais.

137. SANTOS, Joaquim Justino Moura dos. De freguesias rurais a subúrbios: Inhaúma e Irajá no município do Rio de Janeiro. Tese de Doutorado em História Social apresentada no Departamento de História da Faculdade de Filosofia, Letras e Ciências Humanas da Universidade de São Paulo, 1996, p.8.
} 
De todas as atividades lúdico-religiosas, a procissão era a mais importante e a que melhor representava a alma da Penha durante os séculos dezessete e dezoito.

Como já observamos, a participação dos moradores das localidades na procissão não se resumia apenas à presença, cabia-lhes ainda a obrigação de enfeitar as ruas por onde ela passasse. Cabia ao Estado punir com cadeia e multas o indivíduo que não se sujeitasse às posturas pré-determinadas ou que impedisse a participação de alguém, fosse escravo ou não. ${ }^{138} \mathrm{O}$ Estado procurava, de uma forma ou de outra, acentuar seu poder sobre os espaços urbanos.

No bairro da Penha, a procissão envolvia toda a comunidade, porém cada um respeitando a hierarquia pré-estabelecida dentro da comunidade: o clero na frente, políticos e famílias influentes em seguida, e daí por diante toda a sorte de moradores da região. $^{139}$

Na procissão misturavam-se elementos da doutrina católica, elementos da cultura popular e da religiosidade de brancos, de indígenas e de negros. Assim, as festas e procissões eram marcadas por grande colorido cultural, com rezas e ladainhas, com enfeites e fantasias que lembravam elementos medievais e romanos, com danças de negros, com e elementos da cultura indígena, como chocalhos e adornos feitos de palha e penas, além de tabuleiros de quitutes de mais variada origem, junto a farta bebida e a fumaça das velas e do fumo de corda.

Aos poucos, esses elementos culturais foram encontrando e conquistando seus domínios e foram se libertando e ganhando seus momentos e locais de vivência próprios. No século dezoito, como vimos espaços como estes já começavam a se definir. Como exemplos, temos as igrejas para negros e festas como o carnaval. Sobre esse fenômeno vale a citação de Moraes, abaixo:

Para a população mais pobre e escravos tratava-se provavelmente das raríssimas oportunidades de divertimento e um dos únicos espaços públicos onde poderiam colocar em prática suas manifestações específicas. Várias dessas festas já continham em suas comemorações danças e cantorias populares, introduzidas e assimiladas durante séculos e, portanto, de certa forma reconhecidas e admitidas

${ }^{138}$. MARX, M., op. cit., 1989, p.63. Segundo o autor: “As Ordenações Filipinas, como bem demostra esta passagem de seu livro I, título 66, § 48: 'não serão constrangidos vir a ellas nenhuns moradores do termo de alguma cidade, ou villa, salvo os que morarem ao redor huma légoa'. Os moradores, portanto, duma vasta área circundante das sedes municipais estavam obrigados a fazer tais jornadas festivas". O autor ainda cita que "na sessão de 12 de junho de 1632, o procurador da câmara pede que se "condenassem os moradores que não vierão a vila no dia do corpo de deos o que visto pelos ditos ofisiais ouverão todos por condenados em cento e sesenta cada hu dos que não vierão nem enramarão suas ruas".

${ }^{139}$. Ibidem, p.61. 
pelas instituições. Outras destas paulatinamente foram sendo ocupadas por expressões dos diversos grupos étnicos e culturais presentes na cidade, concretizando-se geralmente após os cultos religiosos e celebrações oficiais. [...] para a maioria dos pesquisadores que procuram entender as festas religiosas populares, a tradição da combinação entre os cultos religiosos católicos e as expressões coreográficas sonoras mundanas de vários grupos étnicos está assentada, na sua primeira fórmula, na ação dos jesuítas, que fundiram as celebrações religiosas com adaptações de danças e músicas indígenas [cateretê ou catira, cururu] [...] outro tipo de fusão também se incorporou às formas de comemoração dos festejos paulistanos: a progressiva tendência de penetração dos negros nas festividades [batuques congadas e sambas nos largos das igrejas] $[\ldots]^{140}$

Não é objetivo deste trabalho aprofundar os estudos sobre o desenvolvimento dos elementos culturais relacionados acima. Tais informações têm aqui, o intuito de mostrar a importância do catolicismo para a configuração do bairro da Penha.

A importância das procissões do aglomerado penhense cresceu proporcionalmente à fama milagreira que a padroeira Nossa Senhora da Penha de França conquistava. Porém, a Santa somente conquistou um lugar de destaque na religiosidade paulistana após o início de suas tradicionais trasladações para a cidade. Tais procissões de traslado aconteciam associadas aos períodos em que os fenômenos climáticos ou sanitários ameaçavam castigar a população de São Paulo.

Assim, quando a seca ameaçava a produtividade da lavoura e da pecuária e as chuvas traziam doenças e epidemias, lá ia a Santa piedosa em procissão para a cidade.

Segundo documento da Assembléia Legislativa de São Paulo de 1883,

[...] com freqüência das chuvas torrenciais às quais sucediam dias de elevadíssimo calor, os lagos acidentalmente formados constituem focos de miasmas, que muito concorrem para viciar a atmosfera, alternando e agravando a constituição médica pelo predomínio das febres paludosas, com variados tipos, tornando-se mais salientes as subnitrantes (sic), que tão comumente fazem transição, revestindo-se de fisionomia tífica. ${ }^{141}$

Somando-se a isto, havia ainda as péssimas condições sanitárias da cidade de São

Paulo da segunda metade do século dezenove que tantas doenças disseminavam. Bruno descreve tais condições, apoiado em reportagem do Jornal da Tarde de 1890 que lamentava as péssimas condições higiênicas da cidade, citando as vias públicas com falta de limpeza e fiscalização adequada, a falta de esgoto na maior parte das residências, o acúmulo de lixo e a falta de aterros para áreas como o Bom Retiro. ${ }^{142}$ O que facilitava o aparecimento e proliferação das epidemias.

\footnotetext{
140. MORAES, José Geraldo Vinci de. As sonoridades paulistanas: A música popular na cidade de São Paulo - final do século XIX ao inicio do século XX. Rio de Janeiro: Funarte, 1997, p. 73-75.

141. MELLO NÓBREGA, Humberto de. História do rio Tietê. Belo Horizonte/ São Paulo: Itatiaia/ Edusp, 1981, p.189-190.

${ }^{142}$. BRUNO, E. S., op. cit., 1984, p.1193-1194.
} 
Cabia à Câmara, diante das ameaças que se formavam, solicitar as trasladações da imagem de Nossa Senhora da Penha de seu santuário à Igreja da Sé. Segundo os registros históricos recolhidos por Leonardo Arroyo, o primeiro traslado ocorreu no ano de 1768, e foi seguido de muitos outros: 1780, 1783, 1791, 1816, 817, 1819, 1841, 1842, 1847, 1858, 1859, 1859, 1863, 1864, 1867, 1869, 1873, 1875 e, o último, em $1876 .{ }^{143}$

Parte dessas datas não coincide com as de outro importante historiador da cidade de São Paulo. Segundo Egydio Martins,

[...] a primeira vez que a imagem da Senhora da Penha veio para esta Cidade foi, segundo consta, em 1814, tendo vindo também a mesma Senhora nos seguintes anos: em 1846, por causa da seca; em 1858 e 1863, por causa da epidemia de varíola; em 1869, por causa da grande seca que então assolava não só a Capital como todo o interior da antiga Província; e em 1873 e 1875, por causa da epidemia da varíola; havendo a mesma imagem vindo por diferentes motivos no período decorrido de 1815 e 1845 e que, por não conseguirmos saber ao certo as épocas em que veio, deixamos de mencioná-las. ${ }^{144}$

As procissões sempre seguiam pela antiga Estrada da Penha. ${ }^{145}$

Mesmo com essa confusão de datas, dá para se ter uma idéia da importância da Santa, afinal não foram poucas as suas transladações.

Segundo transcritos das históricas “Atas das Câmara Municipal de São Paulo”, em 29 de maio de 1858 encontraremos uma representação “de cento e trinta e seis cidadãos, residentes na capital, pedindo a vinda da Milagroza Imagem da Senhora da Penha, a fim de ver se esse meio applaca a peste das bexigas; e que a Camara leve esta representação ao conhecimento do Rvmo. Vigário Capitular. "146 Não tardaria a resposta do Vigário Geral da Câmara, datada de 02 de junho de 1858, em ofício “accusando o offo. Desta Camara e juntamente a petição dos habitantes da cide., q. desejarão q. seja conduzida para a Cide. Digo pa. A Sé a Imagem de Nossa Senhora da Penha de França, afim de por intercessão de tão Poderoza Protetora se consiga apartar o flagelo das bexigas." 147 A resposta do Estado, mediante a urgência, também não tardou: que “ $a$ Camara declare o dia e hora em que devera ter lugar a entrada nesta capital da Imagem da Senhora da Penha." ${ }^{148}$ A data escolhida foi uma sexta-feira, 11 de junho do mesmo

143. ARROYO, L., op. cit., 1954, p.179.

144. EGYDIO MARTINS, Antonio. São Paulo Antigo - 1554 a 1910. Coleção São Paulo. Obra original de dezembro de 1911. São Paulo: Paz e Terra, 2003, p.383.

${ }^{145}$. Lembramos que depois da terceira trasladação, o pequeno aglomerado, ou arraial alcançou em 1796 o status de freguesia, conquistando, assim, sua autonomia em relação à paróquia da Sé.

146. Cf. Atas da Câmara da Cidade de São Paulo - 185. Departamento de Cultura, Prefeitura Municipal de São Paulo. São Paulo, 1948, p.101.

147. Ibidem, p.106.

${ }^{148}$. Idem. 
ano e, no dia 10 de junho de 1858 "deliberou-se mais que a Camara fosse em corporação do encontro da Imagem da Senhora da Penha, até o Braz."149

É interessante observar como, burocraticamente, se processava o trâmite para se efetuar a trasladação da Imagem da Nossa Senhora da Penha: primeiro, a petição popular ou de algum político era entregue à Câmara; daí ela seguia até as mãos do governador da Província que a enviava para ser apreciada pelo Vigário Geral que, enfim, a mandava de volta para a Câmara. Cabia a esta organizar e financiar a procissão, exigir que as ruas fossem limpas e enfeitadas, e exigir a presença da população, das pessoas ilustres e dos políticos que acompanhariam a saída e a chegada da Santa peregrina.

Outro bom exemplo foi a procissão de setembro de 1869; segundo ofício direcionado a Câmara Municipal de 22 de setembro de 1869:

[...] Sr. Dor. Vigario Capitular accuza o recebimento de que esta Camara lhe dirigio em 16 do mesmo mez cobrindo a reprezentação assignada por diversos habitantes da capital reclamando pela vinda da Sagrada Senhora da Penha, por cauza da secca que se faz sentir, e declarando que em resposta significava á Camara que estavão dadas as necessárias providencias para tal fim, e que na prezente data foi por S. Exa. Rma. Nomeada uma comissão composta dos Rmos. Conego Joaquim José da Silva, Antonio Augusto de Araujo Moniz e Dor. Cura Marcelino Ferreira Boena para receberem do respectivo parocho a referida Imagem, que devera sahir daquelalla freguesia na manhã do dia 24 do corrente ficando depositada na igreja do Braz até a tarde desse mesmo dia, em que o Rmo. Cabido e Irmandade religiosa irão buscal-a processionalmente ser conduzida até a Cathedral, onde ficará exposta a veneração dos fieis, como é de costume fazer-se. O Senr. Dor. Dutra Rodrigues pedindo a palavra indicou que se nomêe uma comissão composta dos cidadãos doutor Antonio Pinto do Rego Freitas, tenente Corel. Gabriel Marques Cantinho, major Francisco Martins de Alemida, Luiz Pinto Homem de Menezes e Fortunato José dos Santos para tractarem dos festejos que se devem fazer para a recepção da Sagrada Imagem, e que se officie a S. Exa. Rma. o Sr. Dor. Vigario Capitular communicando-lhe esta nomeação. Assim mais que se publique editaes convidando os habitantes da capital á iluminarem as frentes de suas cazas na noite do dia da chegada de Nossa Senhora e nas duas seguintes, e que ordene aos fiscaes á mandarem fazer a limpeza das ruas por onde tem de passar a procissão. ${ }^{150}$

A última grande festa de transladação da imagem de Nossa Senhora da Penha aconteceu em 11 de julho de 1876, quando a mesma deixou a catedral da Sé, onde estava desde 12 de setembro de 1875. Segundo Egydio Martins:

Em 1876, estando na Igreja da Sé Catedral a imagem de N. S. da Penha de França, que havia, a 12 de setembro de 1875, vindo a esta Cidade, o Mosenhor Cônego Arcediago Dr. Joaquim Manuel Gonçalves de Andrade, então vigário geral do Bispado, ordenou, a instância do vigário da respectiva freguesia, a ida, no dia 25 de março de 1876, daquela santa para a sua igreja, travando-se, por causa disso, forte polêmica na seção livre de alguns jornais da época, dando-se, como principal motivo, o fato de que não havia sido de todo extinta a epidemia da varíola, que então reinava nesta Capital, e mesmo por não de ter realizado na Catedral a costumada festa que aqui, por ocasião da estada daquela milagrosa

149 . Ibidem, p.112.

150. Cf. Atas da Câmara Municipal de São Paulo - 1869, Departamento de Cultura, Prefeitura Municipal de São Paulo. São Paulo, 1948, p.217. 
imagem, fazia, tendo a mesma festa, em sua honra, realizado-se a 9 de julho de 1876. [...] Essas festividades, que na Sé Catedral celebravam-se em louvor a mesma virgem da Penha, quando se achava aqui, eram feitas a expensas do povo, que cheio de fé pelos seus milagres, dava, com o maior prazer, o seu óbolo para aquele fim. [...] Não se pode descrever agora a alegria, fora do comum, que se observava em todo os semblantes quanto a Senhora da Penha estava nesta Cidade, tal era a grande confiança que o povo nela depositava. ${ }^{151}$

No dia 9 de julho, houve a festa no período da manhã e cortejo por diversas ruas da capital no período da tarde. No dia seguinte, 10 de julho, grande procissão até a Igreja Matriz do Brás. Na manhã do dia 11 de julho de 1876, pela Estrada da Penha a imagem foi reconduzida em procissão até seu verdadeiro altar.

Segundo Egydio Martins,

[...] nas ruas por onde tinha de passar a solene procissão, erguera-se bonitos arcos de murta e flores, iluminando-se à noite, as frentes de quase todas as casas da Cidade, especialmente do Triângulo [área delimitada pelas ruas Direita, São Bento e XV de Novembro], que foram belamente enfeitadas [...] Para facilitar o trânsito até a Freguesia da Penha, por acasião da ida, a 11 de julho de 1876, da imagem da sua padroeira, a Companhia do Norte [...] pôs pela primeira vez carros de 40 em 40 minutos até a Estação Guaiaúna [...] $]^{152}$

Faz-se necessário aqui dar o devido destaque à Estrada da Penha, ${ }^{153}$ que durante séculos se apresentou como a principal via de comunicação entre o bairro e a cidade de São Paulo. ${ }^{154}$ Segundo Bruno:

As comunicações por terra [...] foram se ampliando e ganhando condições melhores - embora em escala pequena - particularmente em fins do século dezoito quando se acalmara o tropel das bandeiras e começou a de esboçar o ressurgimento da agricultura e do comércio na região de São Paulo e em boa parte da capitania. Então, muitos caminhos antigos já haviam desaparecido, às vezes suplantados por traçados novos. Do centro da povoação [São Paulo] observou Nuto Santana - ia-se pára o lado do nascente pelo caminho correspondente ao traçado da futura rua do Carmo. Rigorosamente, para sueste. Era um caminho estreito, que contornava a colina até a ponte do Tamanduateí ou Tabatingüera, ou ainda do Ipiranga - pois por todos êsses nomes ela foi conhecida na era quinhentista. Logo depois dessa ponte saía uma variante que mais tarde se chamou da Moóca e que levava à Penha - 'o primeiro arranco de casa para os que saíam de São Paulo `no dizer de Antonil - onde se bifurcava. Um ramo ia para Nossa Senhora da Conceição de Guarulhos, Lavras Velhas, Nazaré. O outro, mais ao sul, via Ururaí (são Miguel) e Bougi (Mogi), para o lado do Rio de Janeiro. ${ }^{155}$

Bruno ainda afirma que os pousos para descanso de viajantes e tropeiros já estavam presentes na Estrada da Penha desde o século dezoito, “na época do morgado

151. EGYDIO MARTINS, A., op. cit., 2003, p.381-382.

${ }^{152}$. Ibidem, p.381-384.

153. SANTARCANGELO, M. C. V., op. cit., s/p. A estrada da Penha, antiga picada que havia sido utilizada por indígenas e bandeirantes, também era conhecida como Caminho da Penha, Estrada do Rio de Janeiro. Depois, mudando seu traçado mais para o sul, Avenida Intendente e hoje, Avenida Celso Garcia até o vale do rio Aricanduva, também passagem da Variante Poá da ferrovia central do Brasil, a partir desse ponto começa a Ladeira Cel. Rodovalho.

${ }^{154}$. Nas análises documentais e bibliográficas, as vias fluviais, que seriam a outra forma de comunicação entre o bairro e a cidade, pouco se destacaram. 
Mateus (1765-1775) havia dois pousos para descanso de viajantes no trajeto entre a cidade e a Penha: o do Ferrão e o do Tatuapé»"156. O autor ainda descreve que no século dezessete já havia algumas vendinhas que comercializavam víveres e cachaça na Estrada da Penha por meio de pequenas janelinhas, para evitar o contato direto com os indígenas “que ainda não tinham assimilado bem o conceito europeu de propriedade”. ${ }^{157}$

A partir da segunda metade do século dezenove, o fluxo de transeuntes pela Estrada da Penha tinha aumentado consideravelmente e já se exibia linhas de carruagens circulando na mesma. As relações entre a Penha e a cidade se acentuavam, mas a Estrada, que em época de chuvas mais intensas virava um pântano tornara-se uma barreira complicada. Segundo Bruno, em 1857,

[...] já se falava na Câmara na conveniência de se aperfeiçoar a estrada da Freguesia da Penha de modo que prestasse trânsito fácil e seguro 'a seges e outros veículos semelhantes`. Nesse tempo havia ainda apenas uma casa que alugava carruagens, e duas fábricas de seges na cidade. Do aumento dêsses veículos pelas ruas parece significativo o que se dizia alguns anos depois - em 1861 - nas atas da Câmara: que todos os carros e tílboris que trafegassem pelas ruas deviam ser guiados 'por cocheiros mestres aprovados e matriculados nas polícia' e durante a noite, a partir da hora em que se acendiam os lampiões, com duas lanternas acesas. ${ }^{158}$

A ilustração (1827) que se segue nos dá uma boa perspectiva das características e traçado da estrada da Penha.

155. BRUNO, E. S., op. cit., 1984, p.213. O autor cita as seguintes bibliografias: SANT’ANA, Nuto. São Paulo histórico I. São Paulo: Departamento de Cultura, 1937, p.124 e ANTONIL, André João. Cultura e Opulência do Brasil, Belo Horizonte/São Paulo: Itatiaia/Edusp, 1982, p.258.

${ }^{156}$. Ibidem, p.312. O autor cita como fonte o Registro geral da Câmara da Cidade de São Paulo, XIII, p. 288. Segundo Bruno, no século dezenove as hospedarias do Brasil foram classificadas em cinco categorias pelo viajante Inglês Richard Nurton: "havia uma primeira categoria, que era a do simples pouso para tropeiros; uma segunda, representada pelo telheiro coberto ou rancho, ao lado das pastagens; uma terceira, que era a fase da 'venda', correspondente à 'pulperia' hispano-americana ou ao empório de aldeia inglês combinado com a mercearia e a hospedaria, quase sempre com um quarto para acomodar estranhos; vinha depois a quarta fase - a estalagem ou hospedaria - $e$ finalmente a quinta, mais pretensiosa do hotel.” Pela descrição, as da estrada da Penha não deveriam passar das duas categorias iniciais.

157. Ibidem, p.311.

${ }^{158}$. Ibidem, p.606. 


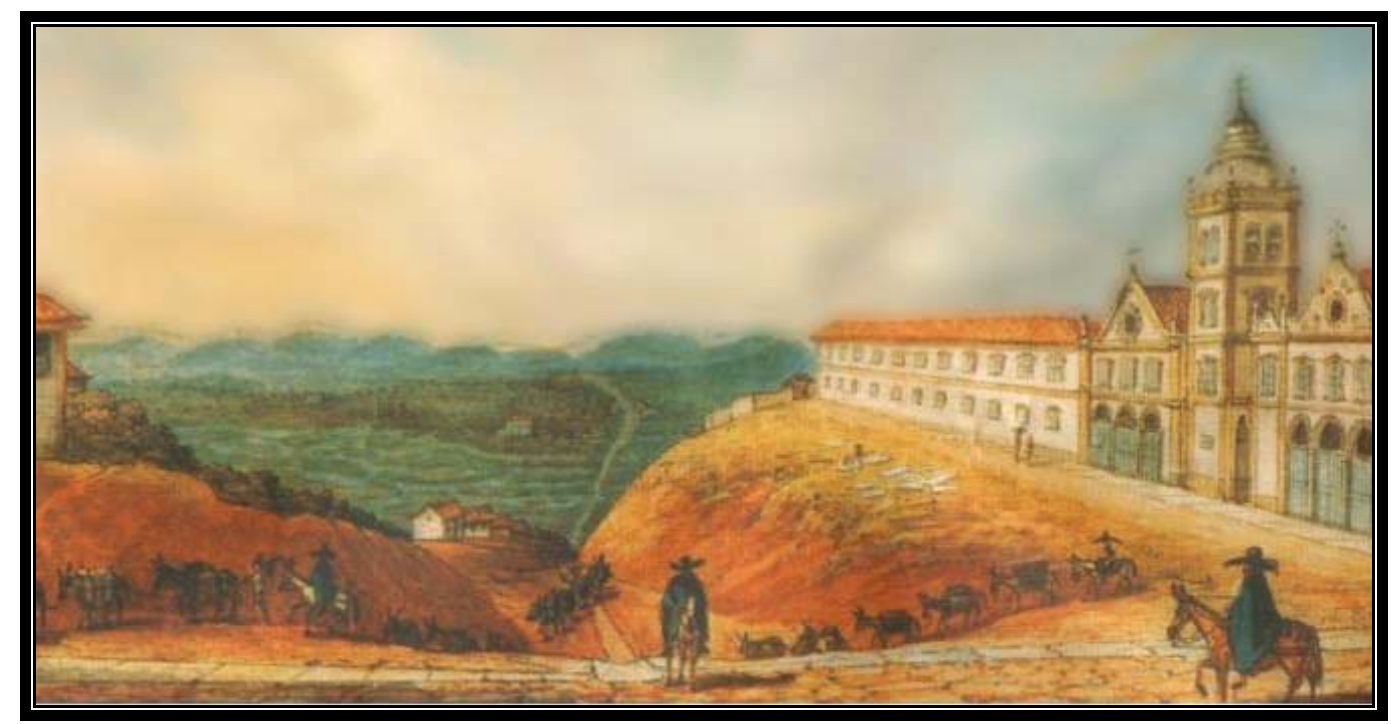

Tropeiros chegando do Rio de Janeiro em 1827. Ao fundo vemos a estrada para a Penha que percorria os vales dos rios Tamanduateí e do Tatuapé. Quadro de Jean-Baptiste Debret. (Memorial da Penha de França, acervo digitalizado)

Outra questão de relevância em relação às grandes procissões, como eram os traslados da Penha, era o fato de atender às necessidades imediatas do Estado (epidemias e secas) e não da Igreja; muito menos atendiam às necessidades da população penhense. Tal condição acabou pesando para a deterioração das tradicionais relações sociais que se mantinham no bairro e isso deveria se agravar ainda mais quando a imagem milagreira, cultuada no âmbito do catolicismo rústico, ficava um tempo longo fora, como o período de 1875-1876. Certamente populares deviam ter suas queixas.

Segundo Seabra, a relação estabelecida entre a Igreja e o Estado até meados do século dezenove acabou permitindo o aparecimento de um "catolicismo de Estado" que atuava "conforme as necessidades da sociedade escravista, veiculando argumentos $e$ práticas de legitimação da escravidão". ${ }^{159}$ Importante ressaltar que Seabra complementa alegando que tal situação não iria se manter por muito tempo, pois a necessidade de aproximação que a Igreja tinha com o povo iria acabar forçando-a a adotar políticas mais independentes, pelo menos por um determinado período histórico, como poderemos conferir mais adiante.

A interferência do Estado nas decisões da Igreja já vinha se intensificando desde 1823. Segundo Morse:

Nos anos posteriores à Independência a Igreja estava perdendo a liderança intelectual em todo o Brasil e deixando que fosse assumida pelas academias de Direito. Muitos dos porta-vozes mais vigorosos da Igreja eram então maçons e regalitas [...] A infiltração da maçonaria na Igreja brasileira criou um cisma que

${ }^{159}$. SEABRA, O. C. L., op. cit., 2003, p.237. 
seria difícil de sanar mais tarde e que comprometeu sua autoridade tradicional. A união de Igreja e Estado pela constituição de 1824 e a aceitação de pontos de vista galicanos pelos principais sacerdotes minou ainda mais sua autoridade, sujeitando os negócios da Igreja à constante intervenção do governo. ${ }^{160}$

Morse cita como exemplo de desmoralização do clero um fato ocorrido na freguesia da Penha:

[...] em 1823, num apelo ao bispo de São Paulo, os paroquianos da Penha protestavam contra um vigário por quem tinham 'aversão' cujas 'maneiras de tractar são bastante duras e incivis, sem que tenha a menor afabilidade, e amizade que são próprias do caracter de um Parocho para seus freguezes. ${ }^{161}$

O Estado também começou a interferir no uso dos espaços considerados pios. Durante as festas do século dezoito, o uso das ruas e praças do bairro da Penha estava tendo interferência direta do Estado e isso desagradava demasiadamente o clero da localidade. Assim, no final da década de 1850, cabia exclusivamente à Câmara Municipal conceder licenças para o uso das cercanias das capelas durante as festas, para a instalação de barracas, tabuleiros e outras formas de comércio. E mais, somente o Estado tinha permissão de tributar esses espaços. A Igreja protestava inutilmente que tais áreas eram sagradas e que somente ela tinha o direito de decidir quando, como e a que custo poderiam ser utilizadas e, portanto, em hipótese alguma cabia ao Estado determinar seu uso.

Como resposta a esses protestos, o presidente da Câmara respondeu, em Ata de 30 de dezembro de 1893, que considerava de

[...] domínio público as ruas e praças da freguesia da Penha de França pela posse ininterrupta em que tem estado a população em geral, outro não poderia ser o procedimento que adoptei, fazendo reverter para os cofres municipaes quaesquer rendimentos provenientes de licença para locação de barracas, etc. Quanto ao pedido que sejam respeitados os ditos terrenos [praças, ruas e lotes vazios próximos a igreja] como estando fóra da attribuição municipal e como tal constituindo posse da egreja deve ser rejeitado, pois a questão deve versar apenas sobre o facto de serem ou não taes logares de propriedade da Camara. ${ }^{162}$

O Estado se fazia presente para definir posturas, no entanto, em outras questões associadas à segurança e à organização ele quase não existia. As queixas sobre a falta de policiamento e a total desorganização do trânsito durante as festividades religiosas eram ruidosas: "o dia de 4 de setembro viu ajuntar-se na Penha uma enorme multidão. Apesar

${ }^{160}$. MORSE, R. M., op. cit., 1970, p.98-99.

${ }^{161}$. Idem. O autor dá como fonte o Arquivo do Estado de São Paulo, lata 10, Capital, 1832.

162. Cf. Atas da Câmara Municipal de São Paulo - 1893. Departamento de Cultura, Prefeitura Municipal de São Paulo, São Paulo, 1948, p.436. Esta lei foi estabelecida em 03 de agosto de 1893. Em seu projeto original consta que: "Art. $1^{\circ}$. Durante o tempo das festas na Freguezia da Penha de França poderão ser concedidas licenças para a edificação de barracas, taboleiros fixos ou outras obras transitórias para negócios licitos nas ruas e praças, mediante uma tabella de preços por licença, organizada pelo presidente da Camara. \& Único. Essa tabella poderá ser sujeita á concurrencia de quem mais der, uma vez que haja mais de um pretendente á algum ou todos lugares demarcados a juizo da intendencia, como fiscal da conveniencia e opportunidade de taes concessões. Art. $2^{\circ}$. Em caso algum 
da falta quasi completa de policiamento [...] apesar do grande número de automóveis a circular sem ordem pelas ruas apinhadas, não houve a lamentar um só desastre.”163

As festas do final do século dezenove eram grandiosas, no entanto não reforçavam a hegemonia do catolicismo local. A festa era mais diversão que reza; era a festa do beber, do comer e do dançar, muito mais para Baco que para santo, ou seja, era a possibilidade de lazer que atraia tanta gente para festas como as que ocorriam na Penha.

Bruno reforça essa idéia afirmando que, após 1870, as manifestações religiosas, principalmente as procissões, já não tinham a mesma força que no período colonial. ${ }^{164}$ As novas possibilidades de recreação - clubes recreativos e/ou esportivos (atividades náuticas e depois o futebol, bilhar, corridas de cavalos, danças), a lanterna-mágica, depois os cinemas, teatros, circos, entre outros, além do protestantismo e do espiritismo que começavam a aparecer em São Paulo ${ }^{165}$ - concorriam com as festas religiosas e as colocavam em segundo plano. Nem mesmo o teor profano que caracterizava as quermesses conseguia assegurar mais a importância das festas religiosas.

Como ilustração do parágrafo anterior, temos uma citação de Bruno afirmando que a Penha já se enquadrava na rotina das novas possibilidades de lazer; “em 1895 [...] já funcionavam duas entidades turfíticas na cidade: o Derby Club, com hipódromo 'na extremidade do Brás’ e o Joquei Club, com campos de corridas perto da Penha”. 166

Segundo Sant'Ana, nas festas do final do século dezenove os elementos profanos se destacavam mais que os sagrados, por exemplo, em festas como

[...] a do Divino, em que havia romeiros esmolando com músicas e cantorias, promovendo-se em seu término procissão e também, como se fazia em Santo Amaro, a célebre dança dos Caiapós; e outras, em que, além do leilão obrigatório de guloseimas, bolos, frangos recheados, perus e leitões, em que enxameavam ditos pitorescos 'aos que mais davam', havia ainda quermesses e, como principal atração, instaladas em barracas de lona, profusamente iluminadas, bancas de jogos de azar de todos os tipos, que iam dos búzios e dados às tômbolas e à roleta. Notabilizaram-se nestes gêneros, na capital, as festas da Penha, que se

essas licenças serão dadas por mais de 30 dias nem tomarão o caracter de aluguel ou arrendamento", p.359-360.

163. Cf. Livro Tombo da Freguesia de Nossa Senhora da Penha, livro códice 8-2-23, aberto em 1873, p.10. No Livro de Tombo da Paróquia registravam-se os momentos mais importantes do dia-a-dia da paróquia. Geralmente confeccionado pelos padres, relatava não só fatos relacionados à vida religiosa, mas qualquer fato que marcasse a vida da paróquia. Os Livros Tombos da Penha são encontrados na Cúria Metropolitana de São Paulo e seguem um endereçamento conhecido por códice (manuscritos e documentos históricos caracterizados pelo formato de livro), sua numeração é formada por três algarismos, o primeiro localiza o armário onde se encontra guardado o documento; o segundo, a prateleira e o terceiro um número pré-estabelecido pelo organizador.

164 . BRUNO, E. S., op. cit., 1984, p.1216-1218.

165. Ibidem, p.1216-1221.

${ }^{166}$. Ibidem, p.1233. 
prolongavam por muitos dias, até a madrugada, terminando com vistosos fogos de artifício. ${ }^{167}$

A religiosidade da festa praticamente foi remetida a um segundo plano, Interesses políticos e econômicos, somados à rápida profanação dos símbolos e ritos católicos, começaram a deteriorar a função integrativa da mesma. Segundo Morse, "reformas na Igreja eram há muito necessárias - mas não com a negação de suas raízes espirituais e do seu culto visual, auditivo, ritual e verdadeiramente comunal. Entretanto, as procissões estavam se tornando obsoletas”168. Isso explica porque no ano de 1876 ocorreu a última trasladação da imagem da Santa da Penha.

O crescimento quantitativo da festa da Penha, enquanto festa da cidade e não dos moradores do bairro, e a crescente degradação qualitativa da mesma também contribuía para o enfraquecimento da Igreja na localidade. Esse infortúnio também atingiu a oligarquia local, outro pilar de sustentação das relações sociais do bairro rural penhense. Tais lideranças tiveram sua influência enfraquecida, foram ofuscados pela grande acorrência de pessoas e pela presença de representantes políticos de maior envergadura no cenário paulistano.

A intromissão do que vinha de fora, havia proporcionado a instrumentalização da festa da Penha. Assim, as festas religiosas começaram a sofrer grandes modificações e a não atender as necessidades dos moradores do bairro. A festa da Penha atendia agora a ordem estabelecida pela cidade.

Segundo Bruno, no final do século dezenove, muitas festas tradicionais haviam desaparecido $^{169}$. Ficaram as festas da cidade para a cidade onde o palco era o bairro. $\mathrm{O}$ bairro penhense vivenciou esse e sua festa manteve-se como mais uma festa da cidade no bairro e não a festa do bairro para o bairro.

As festas da Penha ainda continuavam reunindo muita gente e era considerada a festa da cidade com a maior massa de populares. Esses vinham de todos os cantos. No entanto, as festas se apresentavam com organização, infra-estrutura (regras, policiamento, transportes) e ordem estabelecidas pela municipalidade. Tal condição passou a definir as maneiras do viver no bairro.

A ferrovia e as melhorias na Estrada da Penha (depois Avenida Intendente e mais tarde ainda, Avenida Celso Garcia) tiveram papel importantíssimo nesse fenômeno.

167. SANT'ANA, N., op. cit., 1958, p.445

${ }^{168}$. MORSE, R. M., op. cit., 1970, p.289.

${ }^{169}$. BRUNO, E. S., op. cit., 1984, p.1217. 
Por hipótese, podemos afirmar que, uma vez que as festas deixaram de ser do bairro, houve um enfraquecimento das relações de vizinhança que antes marcavam a vida na localidade. Pela nova forma de se estruturar as festas, aquele momento de comunhão onde os moradores se reuniam para a preparação da mesma se enfraqueceu até desaparecer. As festas foram aos poucos perdendo sua importância de referência para a comunidade e os moradores deixaram de ser protagonistas e tornaram-se meros coadjuvantes.

Para os que não conseguiram se adaptar à nova forma da festa e todo o conteúdo que a intromissão do que vinha de fora significava, acreditamos que pelo sentimento de não fazer parte, acabaram se afastando da igreja. Acreditamos ainda que a prática de vivenciar a religiosidade em casa, tão comum para o catolicismo rústico que ainda tinha muita força entre os moradores da Penha tornou-se uma opção para os que se sentiam excluídos. Esse distanciamento era tudo que a Igreja não queria.

Diante da crise que se instaurava nas ultimas décadas do século dezenove, a Igreja não podia se dar o luxo de perder nenhuma alma e se viu obrigada a buscar novas estratégias de aproximação com os moradores e partir para o enfrentamento direto do catolicismo popular. Mas de que crise estamos falando?

A principio, dois fatores embasavam essa crise: a) a estruturação do capitalismo agrário brasileiro e a decadência da dominação senhorial na área rural ${ }^{170}$ que obrigava a igreja a novas formas de dominação social e arrecadação; b) com a Proclamação da República, 1889, o Estado parou de bancar os gastos das capelas e garantir os soldos dos padres. A sobrivência de paróquias como a da Penha agora dependeria essencialmente da caridade de seus fiéis.

Se a união com o Estado já havia se tornado um problema para a Igreja, a separação, em 1889, degringolou-a de vez. Segundo Morse, “sendo assim menos capaz de exercer pressão sobre as autoridades políticas, a Igreja dirigiu-se diretamente ao povo com um programa atualizado de 'ação social'”. ${ }^{171}$

170. OLIVEIRA, P. A. R., op.cit., 1985, p.239. Segundo o autor, a dominação senhorial era de uma “dominação pessoal, exercida pelo grande proprietário de terra sobre os camponeses aos quais ele concedia uma área para cultivo elou proteção política em troca de serviços. Tal dominação fundia-se nos laços de lealdade entre o dominante e dominado, sendo cimentada pela prestação de serviços diversos em troca de proteção. As relações entre dominantes e dominados são representadas como relações de aliança entre os poderosos e fracos, aliança que se exprime no código familiar: poderosos e fracos constituem uma única família espiritual consolidada pelos laços de compadrio. $O$ Catolicismo Popular, representando a dominação pessoal como uma representação terrena das relações que ligam o homem a seus protetores celestiais, desempenha uma função social importante para a dominação senhorial, uma vez que ela identifica como ordem do mundo desejada por Deus.

${ }^{171}$. MORSE, R. M., op. cit., 1970, p.289. 
O Estado até que garantia a realização da festa, seja patrocinando-a, seja obrigando a população a financiá-la e prepará-la, no entanto, nos demais dias do ano ficava uma dúvida: de onde viriam os recursos para o sustento da paróquia?

A questão era, ou traziam-se os fiéis para o interior das igrejas, principalmente aqueles mais abastados e influentes, ou não seria possível mantê-las.

Tal determinação não combinava com a prática do catolicismo rústico e muito menos com a postura de se freqüentar a igreja apenas nos dias de festa. Era necessário minar os poderes dos santos caseiros e estabelecer de forma clara que somente os ritos oficiais preconizados pelo clero regular trariam a glória e verdadeira salvação. Assim, vários santos foram 'descredenciados’ e a crença nos leigos e objetos milagreiros passaram a sofrer intensa campanha para caírem no descrédito. ${ }^{172}$ Esse processo de combate às devoções não oficiais recebeu a denominação de Romanização.

Romanização foi o conjunto de medidas adotas pela Igreja Católica de Roma para enfrentar a crise que se estabelecia a partir da separação entre o poder canônico e os Estados. Tal crise se efetuava em escala mundial e no Brasil se intensificou a partir Proclamação da Republica.

A Romanização objetivava, antes de qualquer coisa, substituir definitivamente o catolicismo popular pelo catolicismo oficial e seu sucesso dependia da criação de uma nova Igreja com o clérigo regular mais fortalecido e as devoções e ritos oficializados conforme os propósitos da Santa Sé. ${ }^{173}$

Lembramos que o catolicismo oficial já era praticado pelas classes dominantes, ${ }^{174}$ principalmente porque os filhos dos grandes proprietários das lavouras de café estudavam na Europa e já estavam acostumados com essas novas concepções religiosas.

Para a Igreja, o catolicismo rústico era um grande problema, pois ignorava totalmente a crença nos dogmas fundamentais do catolicismo: a crença do fiel passava por cima do pastor, não comungava, não crismava, não se confessava, não freqüentava a

172. Era comum a adoração de defuntos que tinham morrido por uma causa justa, de crianças que eram beatificadas, de pessoas que diziam ter contato com figuras celestiais e de objetos, como roupas, ídolos e crucifixos que fossem diretamente associados a estes.

173 .SEABRA O. L. C., op. cit., 2003, p.238.

${ }^{174}$. BÔA NOVA, A. C., op. cit., 1981, p.31. Para o autor, Catolicismo Oficial se entende como o "conjunto dos ensinamentos formulados pela camada dirigente da Igreja, ligada de algum modo às classes dominantes da sociedade global, em suas linhas gerais, ele reflete a cultura dominante. Analiticamente, o conceito pode ser estendido aos ritos oficiais e à organização religiosa formal" 
igreja, não seguia os sacramentos e também não contribuía. Lembramos que o núcleo da crença do catolicismo popular é o santo e não o dogma. ${ }^{175}$

A Romanização coincidia com o processo de urbanização. Segundo Morse, na tendência cosmopolita da cidade de São Paulo, a Igreja

[...] procurava restaurar a velha base moral e espiritual luso-católica para a sociedade. Isto implicava em aceitar novos desafios e novos modos de competição. O que significava colocar a Igreja em relações com os novos padrões sociais e ideais, embora se tratasse de uma relação de tensão, ao invés de uma conciliação orgânica. ${ }^{176}$

Essa tendência cosmopolita nada mais foi do que a ingerência do modo de vida urbano sobre as antigas tradições. As festas e procissões da Penha haviam deixado de se apresentar como repositórias de uma cultura popular, pois os elementos que passaram orientá-las eram comprometidos com a mentalidade urbana. Tal concepção não foi um rompimento imediato, surgiu de forma contínua e teve suas estruturas resultantes da fusão de vivências dos mundos urbano e rural. Segundo Moraes:

A grande ruptura parece que se concretizaria, de fato, com a instituição do modo de vida urbano na passagem do século [dezenove para o vinte] e nas modificações sucessivas, embora lentas, nos modos de representação e criação cultural. A partir desse momento, torna-se visível a desestruturação ou transformação de inúmeras destas, pois a vida urbana desestabilizava gradativamente limites e valores do mundo rural, ainda permanentes na cidade, retirando de muitas festas as referências e funções reais a que estavam vinculadas, muitas vezes sem colocar nada no lugar. Ao analisar o folclore em São Paulo num período posterior, Florestan Fernandes identificava, nas rápidas e profundas modificações urbanas da cidade, o impulso de desagregação da cultura ainda vinculada ao mundo rural, não permitindo a manutenção de certos valores e modos de vida [...] Sem dúvida alguma o processo do desenvolvimento urbano de São Paulo foi extremamente rápido para uma cidade provinciana, fechada nos limites do universo rural, tornando-o dramático para a população pobre, mesmo para os imigrantes já integrados ao universo urbano. Mas é justamente dentro desse quadro de instabilidade, construído pelos conflitos e tensões entre valores renovadores e os permanentes com novos e diferenciados agentes sociais, trazendo inúmeras e diversas experiências de vida, que a cultura popular urbana em São Paulo seria reduzida apontando para vários caminhos. ${ }^{177}$

Os conflitos e tensões caracterizados pelos fatores econômicos e políticos e associados à profanização que se estabelecia nas festas e procissões da Penha, já assinaladas aqui, revelavam a dominação crescente da cidade sobre o bairro rural da Penha que, gradativamente, se enfraquece enquanto realidade rural. Agora, é o urbano, com todos os elementos de sua hegemonia, que passa a se impor.

\footnotetext{
${ }^{175}$. Ibidem, p.67. O autor afirma que "o Santo corporifica-se na imagem. Não é qualquer imagem do Santo que serve. Mas a imagem considerada milagrosa, a imagem que está neste altar, ou naquele Santuário, ou que pertence a esta determinada pessoa. Nela os fiéis querem tocar. Muitas vezes a figura do Cristo se enquadra nesta categoria e ele é tratado como Santo semelhante aos outros. Por outro lado é comum atribuírem-se aos Santos alguns papéis que a ortodoxia católica reservaria à divindade"

${ }^{176}$. MORSE, R. M., op. cit., 1970, p.146.

177 . MORAES, J. G. V. de, op. cit., 1997, p. 115-116.
} 
Finalizando, a procissão e as festas religiosas ainda mantiveram sua importância no bairro, no entanto, perderam o caráter de aglutinadoras da cultura tradicional. Tais eventos religiosos da cidade na Penha ainda continuariam atraindo muitos populares durante as primeiras décadas do século vinte ${ }^{178}$, no entanto, deste período em diante, as mesmas foram se tornando cada vez mais acanhadas até se reduzirem a cortejos locais.

\subsection{A questão da terra enquanto fator de enfraquecimento da realidade rural na Penha}

O papel da ideologia católica na construção da cultura popular penhense, mais precisamente das manifestações associadas às tradições do catolicismo popular, e suas implicações sociais e espaciais é elemento importante para o entendimento da Penha como bairro rural. Vejamos agora, o contexto econômico que levou à transformação do antigo bairro rural da Penha em espaço urbano.

Segundo Martin, a partir de 1850 o fim da escravatura apresentou-se como momento de ruptura frente ao ruralismo reinante durante todo o período colonial e presente até as primeiras décadas da Independência. A seu ver:

[...] de fato, há todo um movimento inovador que tende a separar irremediavelmente o 'velho', caracterizado pelo predomínio da produção agrária e escravista voltada inteiramente para o mercado externo do 'novo', marcado pelo industrialismo, pelo trabalho livre e pela maior significação do mercado interno. Em suma, todos parecem reconhecer que o país vivia um período de transição onde os valores aristocráticos típicos da situação colonial passam a ser substituídos por valores burgueses que tentam se impor sobre a nação que se forma. Há que se assinalar, além disso, uma série de inovações tecnológicas que vieram alterar profundamente as condições gerais de produção. Entre elas destacam-se a navegação a vapor, as ferrovias e o telégrafo, as quais melhoraram sensivelmente a comunicação e o transporte, retirando do isolamento um grande número de núcleos urbanos. Nos centros maiores, pela primeira vez em nossa história, o nível de conforto à disposição da classe dominante igualou-se ao das cidades européias e norte-americanas. Além disso, deve-se ressaltar que o café trouxe consigo uma vigorosa imigração de europeus, responsáveis pelo desenvolvimento de formas assalariadas de relações de trabalho, o que foi determinante para a consolidação do mercado interno. ${ }^{179}$

Segundo Martin, essas transformações apresentaram-se como base para a industrialização e trouxeram significativas mudanças quantitativas e qualitativas para a

${ }^{178}$. BRUNO, E. S., op. cit., 1984, p.1225. Segundo Bruno, “algumas festas religiosas tradicionais [...] se mantiveram até o começo do século atual [século vinte], desaparecendo então. A de Nossa Senhora da Penha - que se fazia cada dia 8 de setembro - até 1903.” A festa perdeu seu caráter oficial para o calendário oficial litúrgico paulistano, - festas como as de Santo Antônio, São João e São Pedro, ordenadas pela romanização, receberam maior destaque e são famosas até os dias atuais; a festa da Penha, por origem, era mais uma daquelas associadas ao catolicismo rústico que tinha sobrevivido mas não deixou de existir e de atrair pessoas como poderemos constatar mais adiante.

${ }^{179}$. MARTIN, A. R., op. cit., 1984, p.13-14. 
urbanização. No entanto, como herança do período colonial, este autor acentua a permanência de um elemento de extrema resistência ao ‘novo’ que se apresenta:

[...] referí-mo-nos sem dúvida à solidez do latifúndio exportador, que se manteve como a base econômica do país mesmo após haver sido iniciada a industrialização. Sua permanência seria a responsável por uma acomodação com o passado, acentuando traços que estavam presentes já no início da colonização [...] A auto-suficiência do latifúndio e a dependência dos núcleos urbanos face ao mercado externo, criaram um fosso profundo entre campo e cidade [...] Tal contradição só não explodiu em rupturas mais profundas no tecido social porque no urbano estavam representados não os seus próprios interesses, mas exatamente o dos produtores, isto é, o dos proprietários rurais. A ausência de uma produção urbana mais significativa impediu assim, que a diferença entre e cidade e campo gerasse um conflito. ${ }^{180}$

Se nos grandes centros urbanos do período, a força do 'velho’ se apresentava com tamanha grandeza imagine em áreas urbanas estagnadas como o bairro rural penhense.

Segundo Rolnik, ao longo do século dezenove, a terra gradualmente vai substituindo o papel do escravo na composição da riqueza dos fazendeiros. A renda capitalizada que antes era imobilizada na figura do escravo passou a ser conferida à terra. Segundo esta autora,

[...] a Lei de Terras [1850] foi o resultado desse processo, na medida em que, concedendo um estatuto jurídico, a terra poderia ser hipotecada, servindo de garantia para a contratação de empréstimos bancários, em um momento em que estes se ampliavam como estratégia para a expansão dos cultivos. A partir daí, a propriedade imobiliária apresentou tendência à valorização $[. . .]^{181}$

É importante ressaltar que a capitalização da terra apresentou-se como compensação para o fim do trabalho escravo. Para Martins, no regime de terras capitalizadas

[...] a renda territorial surge da metamorfose da renda capitalizada na pessoa do escravo; surge, portanto, como forma de capital tributária do comércio, como aquisição do direito de exploração da força de trabalho. A propriedade do escravo se transfigura em propriedade da terra como meio para extorquir trabalho e não para extorquir renda. ${ }^{182}$

Mas, como esse fenômeno pode ajudar a compreender as transformações em curso no antigo bairro rural da Penha? Grosso modo, a possibilidade de comercialização da terra traz consigo grandes modificações, pois agrega valor de troca a mesma em

${ }^{180}$. Ibidem, p.15-16.

${ }^{181}$. ROLNIK, Raquel. A cidade e a lei: legislação, política urbana e territórios na cidade de São Paulo. São Paulo: StudioNobel/Fapesp, 1997, p.24.

182. MARTINS, José de Souza. O Cativeiro da Terra, 6a ed., São Paulo: Hucitec, 1996, p.32. Segundo o autor, "escravo tinha dupla função na economia da fazenda. De um lado, sendo fonte de trabalho, era o fator privilegiado da produção. Por esse motivo era também, de outro lado, a condição para que o fazendeiro obtivesse dos capitalistas (emprestadores de dinheiro), dos comissários (intermediários na comercialização do café) ou bancos o capital necessário seja ao custeio seja à expansão de suas fazendas. O escravo era o penhor de pagamento dos empréstimos. Por isso praticamente todo capital de custeio provinha de hipotecas lançadas sobre a escravaria das fazendas. Tendo o fazendeiro imobilizado nas pessoas dos cativos os seus capitais, transfigurados em renda capitalizada, subordinava-se uma Segunda vez ao capital comercial, mediante empréstimos, para poder pôr em 
detrimento do valor de uso. Uma vez transformada a terra em mercadoria não há mais como garantir a manutenção dos antigos moradores responsáveis pela realidade de localidades como a Penha do século dezenove. A reprodução das relações sociais que estruturavam esta realidade fica comprometida.

A industrialização, como mostraremos adiante, acentuará ainda mais os fenômenos descritos. Agora voltemos à questão da terra para tentar discutir as transformações que ocorreram no bairro rural.

Como vimos, foi do sistema de sesmaria que surgiu o patrimônio religioso que deu origem ao bairro rural penhense e do caráter de transferência hereditária da terra que tivemos a garantia da manutenção do tradicionalismo na localidade. O filho que herdava a sesmaria dava continuidade ao projeto de vida de seu pai; dificilmente se desfazia da terra e muito menos do status social que lhe era conferido e lhe permitia, junto com a Igreja, controlar o aglomerado.

Com a Independência do país, decretou-se o fim do regime de posses por concessão. A partir da Resolução de 17 de julho de 1822, que permitia o apossamento pelo usufruto, iniciou-se a regularização das terras já habitadas e ampla procura de terras devolutas ${ }^{183}$ para ocupação. Segundo Lima, “depois da abolição das sesmarias, então, a posse passou a campear livremente, ampliando-se zona a zona, à proporção que a civilização dilatava a sua expansão geográfica [...] era a ocupação tomando lugar da concessão”. 184

O que justificava o fim do regime sesmarial era sua total ineficiência.

Segundo informe panfletário do "tempo da Independência”, é possível observar em que pé se encontrava o regime de sesmarias do Brasil e quais os problemas que ele enfrentava:

[...] $1^{\circ}$ ) Nossa população he quasi nada, em comparação da immensidade de terreno que occupamos há trez seculos; $2^{\circ}$ ) As terras estão quasi todas repartidas, e poucas há a distribuir, que não estejão sugeitas a invasões dos índios; $3^{\circ}$ Os abarcadores possúem até 20 legoas de terreno, e raras vezes consentem a alguma

movimento os seus empreendimentos econômicos, inclusive para promover a abertura de novas fazendas e adquirir equipamentos de benefício". p.26.

183. LIMA, Ruy Cirne. Pequena História Territorial do Brasil - sesmarias e terras devolutas. São Paulo: Arquivo do Estado, 1991, p.70. Terras devolutas são definidas por Cirne Lima como: "(1) as que não se acharem no domínio particular por qualquer titulo legítimo, nem forem havidas por sesmarias ou outras concessões do governo geral ou provincial, não incursas em comisso, por falta de cumprimento das condições de medição, confirmação e cultura; 2) as que não se acharem dadas por sesmarias ou outras concessões do governo, que, apesar de incursas em comisso, forem revalidadas pela lei; 3) as que não se acharem ocupadas por posses, que, apesar de não se fundarem em título legal, forem legitimadas pela lei; 4) as que não se encontrarem aplicadas a algum uso público nacional, provincial ou municipal (art.3)”.

${ }^{184}$. Ibidem, p.51. 
familia estabelecer-se em alguma parte de suas terras, e mesmo quando consentem, he sempre temporariamente e nunca por ajuste, que deixa ficar a familia por alguns annos; $4^{\circ}$ Há familias pobres, vagando de lugar em lugar, segundo o favor e caprixo dos proprietarios das terras, e sempre faltas de meios de obter terreno em que fação hum estabelecimento permanente; $5^{\circ}$ ) Nossa agricultura está o maior atrazo, e desalento, a que ella pode reduzir-se entre qualquer povo agricola, ainda o menos avançado em civilização. ${ }^{185}$

A ocupação deveria resolver o problema do pequeno proprietário rural, o posseiro, que se instalava às margens dos grandes latifúndios. No entanto, resolveu apenas em parte e não significou o fim de distorções anteriores. A concentração das terras continuou a campear em solo brasileiro e foram poucos e tímidos os mecanismos adotados para solucionar tais distorções.

Os que possuíam maiores privilégios continuaram a tê-los e os limites dimensionais dos apossamentos estabelecidos pela Lei de Terras não foram respeitados e, ao contrário do que pregava a lei, os grandes latifundiários continuaram impunemente a manter suas propriedades e muitas vezes ainda solicitavam, e eram atendidos, a ampliação das mesmas.

Outros problemas eram associados ao fim do regime de sesmaria: a posse ocorria de forma desorganizada e a questão da medição da terra era extremamente confusa; os posseiros mediam-nas a olho ${ }^{186}$, proporcionando o aparecimento de novos latifúndios em terras já regularizadas e conflitos entre proprietários; as compras e vendas das posses passaram a acontecer irregularmente e cada vez com mais freqüência, resultando em valores venais incoerentes.

A falta de parâmetros para a regularização das posses exigiu o estabelecimento de leis mais severas. Assim, decretou-se a Lei número 601 de 18 de setembro de 1850, com aprovação no mesmo ano e sua aplicação somente a partir de 1854. A regulamentação, baseada no direito romano de posses, vai garantir direito à terra aos posseiros que a ocupavam com culturas. ${ }^{187}$

A Lei de Terras de 1850 não legitimou as terras de imediato, preferindo primeiro adotar um regime de transição e comprometendo-se em reconhecer direitos. Embora

185 . Apud, LIMA, R.C., op. cit., 1991, p.46.

186. Usava-se aleatoriamente, frases do tipo: "daquela vertente às margens daquele rio", "do barranco esquerdo de tal picada às terras de fulano de tal”, entre outras.

187. LIMA, R.C., op. cit., 1991, p.52. Citando as leis, o autor assinala que "a provisão de 14 de março de 1822 claramente o diz: - 'Hei por bem ordenar-vos procedais nas respectivas medições $e$ demarcações, sem prejudicar quaesquer possuidores, que tenhão effectivas culturas no terreno, porquanto devem elles ser conservados nas suas posses, bastando para título as reaes ordens, porque as mesmas posses prevaleção ás sesmarias posteriormente concedidas'; e a Lei de 1850, "dispondo do ulteriormente sobre o assunto, fala, por igual, posses 'que acharem cultivadas ou com principios de cultura' (art.5), de posseiros com direito sobre ó terreno que ocuparem com effectiva cultura' (art. 8)". 
admitisse, pelo preceito da cultura efetiva, a existência de grandes propriedades fundiárias, a Lei de 1850 se comprometia, na medida do possível, a corrigir os excessos.

A nova legislação procurou o reconhecimento da posse com muita cautela. Afinal, a expropriação em massa dos que a ela não se adequavam, poderia proporcionar graves problemas sobre a frágil economia brasileira.

Se por um lado, a Lei de Terras de 1850 determinou que o acesso à terra só se efetuaria pelo mecanismo da compra, ao mesmo tempo em que legitimava a posse das mesmas já ocupadas, por outro, o regime jurídico para aquisição de terras que se encontravam devolutas apresentava-se rigoroso e burocrático, chegando até a instituir penas pesadas para quem fosse surpreendido derrubando e/ou queimando matas neste tipo de espaço.

Caso o posseiro já possuísse terras e pretendesse assegurar nova posse, a Lei de 1850 propunha que no momento da legitimação ele deveria provar sua eficiência produtiva por averiguação e confirmação pelos fiscais do Estado. Conforme Lima, “ $a$ capacidade econômica do posseiro demonstrada pelo cultivo eficiente de suas terras, a lei a recompensa, concedendo-lhe outro tanto a que possuir, nas terras que houver contíguas, ״188 porém, a extensão dessas terras não podia exceder ao tamanho das demais regularizadas naquela comarca ou nas comarcas vizinhas.

Como vimos, a Lei de Terras de 1850 proibida o acesso às terras devolutas por outro título que não fosse pela compra. Como todas as terras devolutas pertenciam ao Estado, somente ele estava autorizado a vendê-las ou fazer o que bem entendesse. Graças a essa especificação, parte das terras da cidade mantiveram-se desocupadas e algumas décadas depois acabaram aproveitadas para a instalação dos equipamentos ferroviários e outros usos públicos. ${ }^{189}$

O objetivo maior da Lei de Terras de 1850 era definir limites menos confusos entre o que deveria ser de uso público e o que deveria ser de uso privado.

Desta forma e voltando à nosso objeto, com o fim do regime de sesmarias a regularização dos assentamentos também se fez necessária na região da Penha. Entre a Resolução de 17 de julho de 1822 e a implementação da Lei de Terras de 18 de setembro 1850, nada se alterou na localidade, pois grande parte dos terrenos da região já possuía

\footnotetext{
188 . Ibidem, p.66.

189. Ibidem, p.70. O autor cita o artigo 12: “1) para a colonização dos indígenas; 2) para a fundação de povoações, abertura de estradas e quaisquer outras servidões, e assento de estabelecimentos públicos; 3) para a construção naval.”
} 
proprietários e se apresentava com seus limites praticamente definidos. No bairro, o que ainda não estava claro eram os limites entre o público e o privado.

Como vimos, à Igreja efetuar registros simples de compra e venda.

A partir de 1854, quando a lei de Terras de 1850 tem sua aplicação definida, ocorreu a necessidade de regularização das posses. Assim, os moradores da Penha foram até a sede da freguesia para oficializar, por meio de precários registros, a posse de seus terrenos.

Esses registros, instrumentos rudimentares, receberam a denominação de “Registros Parochiais de Terras”"190 e como o próprio nome já diz, eram documentos lavrados nas sedes das paróquias e freguesias. O vigário dessas sedes era o responsável pela oficialização dos documentos.

Por que a Igreja aparece neste processo? Segundo Seabra, "o catolicismo brasileiro fora sendo construído em dois níveis: um, que respondia às necessidades do Estado, e outro às necessidades do povo. O Estado era o governo colonial com suas estruturas, aliás, bem distanciadas do povo. Mas paradoxalmente, a estrutura Estado que chegava ao povo era a Igreja [...]” Para Seabra, os registros paroquiais só poderiam acontecer na Igreja, pois nela já ocorriam os registros de batismo, casamentos e óbitos que tinham o devido reconhecimento civil. Em termos jurídicos, a Igreja se apresentava como parte da estrutura do Estado. ${ }^{191}$

Segundo Seabra, a Igreja se apresentava como a única instituição capaz de viabilizar tais registros, pois era a única que se encontrava "plantada territorialmente”, ou seja, que realmente se encontrava presente no dia-a-dia do povo. ${ }^{192}$

Voltando aos registros paroquiais da Penha, vamos observar alguns exemplos recolhidos no Arquivo do Estado de São Paulo:

$\mathrm{Eu}$, abaixo assinado, sou senhor e possuidor das terras seguintes nesta freguesia de Nossa Senhora de Penha de França. Um sítio de terras lavradias sito no pátio da Matriz, as quais devidem-se por um lado com terras de Tomé José do Nascimento e Miguel Jacó, possuo valo que começa logo atrás da cozinha e vai até o ribeirão Aricanduba; por outro lado com terras de Camillo Belellis Barbosa, Bento José Gonçalves e João Lopes de Barros por um valo que vai do ribeirão Aricanduba e pelos fundos com o mesmo ribeirão Aricanduba. Este sítio foi por

190. Os Registros Parochiais de Terras foram documentos elaborados entre 1850 e 1890, encontrados no Arquivo do Estado de São Paulo. Por se apresentarem em péssimo estado de conservação, o acesso a eles é restrito (os documentos apresentados são lidos por um funcionário). Assim, somente foi possível colher alguns casos.

191 . SEABRA O. L. C., op. cit., 2003, p.239.

192. Idem. A autora afirma que o papel cartorial que a Igreja assumia tinha lá suas vantagens, pois, apesar de se colocar como continuidade do Estado, ao registrar batismos, casamentos, óbitos e terras, ocorria seu fortalecimento enquanto referência sociocultural. Tais registros fortaleciam os laços entre o povo e a mesma. 
mim comprado [a] Dona Maria dos Anjos Barbosa em 1845 por escriptura pública datada de 10 de Novembro de 1845, lançada nas notas do escrivão Fortunato José da Silva, na cidade de São Paulo. Freguesia da Penha de França, 30 de Outubro de 1855. Antonio Benedicto de Camargo. Penha de França, 30 de Outubro de 1855. O Vigário Antonio Benedicto de Camargo. ${ }^{193}$

Terras que possuem Salvador do Espirito Santo, Maria Dionisia e Francisca Maria nesta freguesia de Penha de França. Nós, abaixo assinados, somos senhores e possuidores das terras seguintes nesta freguesia: Um sítio de terras lavradias no Bairro denominado cabeceira do rio Gualhauna, as quais dividem pela frente com terras da fazenda de Aricanduba, por um lado dividem-se com as terras do finado padre Francisco Froes e para outro lado dividem-se com as terras do Dr. Gabriel e pelos fundos dividem-se com as terras de Venceslau Gonçalves. Este sítio possuímos por herança [ que nos ficou de] nosso falecido pai Francisco Lopes de Barros. Freguesia da Penha, digo, de Nossa Senhora da Penha, 20 de Maio de 1856. Salvador do Espirito Santo, a rogo de Maria Dionisia, José Alvares Boeno, a rogo de Francisca Maria de Sousa Lopes. Penha de França, 31 de Maio de 1856. O Vigário Antonio Benedicto de Camargo. ${ }^{194}$

Eu, abaixo assinado, que sou senhor e possuidor da metade do sítio denominado Aricanduba na freguesia de Nossa Senhora de Penha de França, com terras de lavoura e campos de 'criagem' e suas divisas são as seguintes: principia na ponte do Aricanduba que fica acima da casa do falecido Capitão Manuel de Salles, descendo pelo rio abaixo até a passagem de Theresa de Vieira e daí seguindo o caminho até o Galhaúna e seguindo pelo córrego acima à Boa Vista e daí segue o caminho [?] na ponte aonde principia primeira divisa, entrando em capão que fica num lugar chamado Canavial à esquerda do caminho que vai para a Penha. A metade deste sítio me pertence por arrematação [que fiz] em praça de dez de janeiro do decorrente, e a outra metade pertence ao Dr. Ferraz de Almeida, estando ainda por dividir. São Paulo, 30 de Maio de 1856. Custodio Fernandez da Silva. Penha de França, 31 de Maio de 1856. O Vigário Antonio Benedicto de Camargo. ${ }^{195}$

Terras que possui Camillo Vilellis Barbosa na freguesia da Penha de França, [...?] na cidade de São Paulo. Um terreno de terras lavradias na chegada do pátio da freguesia, lado direito, as quais dividem-se pela frente com a estrada, de uma lado com as terras de Bento José Gonçalves e por outros lados com terras do Reverendo Vigario Antonio Benedicto de Camargo. Esse terreno possuo por herança [...] [do] finado Vigário Jose Rodrigues Coelho [...?], a rogo de Camillo Vilellis Barbosa, por não poder escrever, Jose Antonio de Moraes. Freguesia da Penha de França, 31 de Maio de 1856. O Vigário Antonio Benedicto de Camargo." 196

Nota-se a dificuldade de se estabelecer limites precisos aos terrenos e de se identificar a localização das posses. Na definição dos limites dos terrenos cita-se um acidente geográfico (rios, barrancos, alagados, etc.) ou uma obra produzida pelo homem (uma pastagem, um canavial, uma picada, uma casa etc.) ou os nomes dos vizinhos. Apesar das dificuldades de demarcação, eram lavrados documentos de propriedade.

Observa-se que os terrenos não se encontravam longe do patrimônio da freguesia e que não eram muito grandes, visto que o primeiro registro se encontra entre o rio Aricanduva e o largo da matriz. Observa-se, também, que predominavam o uso da terra para a lavoura e atividades criatórias.

193 . Cf. Registro Paroquial de Terras, Livro 169, Penha de França, 1855, registro número 18, p.07.

${ }_{194}$. Cf. Registro Paroquial de Terras, Livro 169, Penha de França, 1855, registro número 105, p.35.

195 . Cf. Registro Paroquial de Terras, Livro 169, Penha de França, 1855, registro número 38, p.38.

${ }^{196}$. Cf. Registro Paroquial de Terras, Livro 169, Penha de França, 1855, registro número 117, p.39. 
É possível verificar ainda que em dois relatos encontramos terras pertencentes a religiosos. Naquele período registravam-se terras da Igreja no nome dos sacerdotes e somente após a Proclamação da República é que foram transferidas para o domínio da Cúria Metropolitana.

Outro detalhe: as amostras foram registradas entre outubro de 1855 e maio de 1856, mas entre 1822 e 1850 a comercialização da terra já existia. No primeiro registro observamos a comercialização da terra antes da regulamentação da Lei de 1850. Todas as ‘escrituras’ foram lavradas na própria freguesia, porém, com a presença de um escrivão de notas, fato que não se repetiu nos registros paroquiais.

Transformar a terra em mercadoria não era a única preocupação do Estado. Somava-se a isto, a necessidade de melhorar a infra-estrutura mínima para facilitar o controle, tanto para as terras devolutas como para as alienadas, visando possíveis novos tributos.

Para as terras que eram regularizadas recaíam várias ordenações. Segundo Lima, aos proprietários de terras a Lei de 1850 estipulava obrigações como as propostas no artigo 16:

1) a ceder terreno preciso para estradas públicas de uma povoação a outra, ou algum porto de embarque, salvo o direito de indenização das benfeitorias e do terreno ocupado; 2) a dar servidão gratuita aos vizinhos, quando lhes for indispensável para sair a uma estrada pública, povoação ou porto de embarque, e com indenização, quando lhes for proveitosa, por encurtamento de um quarto ou mais de caminho; 3) a consentir a tirada de águas desaproveitadas e a passagem delas, precedendo (sic) a indenização das benfeitorias e do terreno ocupado. ${ }^{197}$

E se não bastasse, cabiam ainda aos proprietários a construção e conservação de estradas, de portos e outras incumbências que pertenciam ao Estado.

Apesar das regulamentações dos assentamentos na Penha, as várzeas dos rios se mantiveram praticamente desocupadas.

A definição sobre como lidar com tais parcelas do solo paulistano apresentou-se confusa e morosa, arrastou-se por muitos anos e resultou em vários conflitos.

Temos na freguesia da Penha, alguns exemplos de conflitos associadas à questão descrita no parágrafo anterior. Na Ata da Câmara da Cidade de São Paulo, de 1852, datada de 21 de agosto, observamos o caso das invasões das terras no local onde antes era encontrada a antiga aldeia de São Miguel. Tal caso recebeu atenção especial da província, pois se arrastou por bom tempo: o fiscal da freguesia da Penha da época relatava que tinha ido a mando da Câmara ao aldeamento e havia mandado "demolir e arrasar todos os feixos de varas q. encontrou feitos pr. José Mariano de Abreu, em terrenos de servidão 
publica.”198 Como o problema não se resolveu, naquele mesmo ano, outro requerimento chegou à Câmara

[...] pedindo que. a Cama. mande o Fiscal da Frega. da Penha á extincta Aldêa de S. Miguel, afim de demolir os feixos pr. José Mariano de Abreu pela $4^{\circ}$ ou $5^{\circ}$ vez, em terrenos de servidão publica, e ao mmo accusão ao Fiscal da Capital de em vez de cumprir as determinações da Camara, antes quiz tornar-se benigno ao Suppedo. Je. Mariano de Abreu. ${ }^{199}$

A crise só terminou depois que o tal fiscal foi demitido e substituído.

Para a organização dos terrenos e logradouros das áreas dos antigos patrimônios religiosos também foram estabelecidas novas leis. Porém, no núcleo central da Penha, tal organização ainda esbarrava nos interesses da Igreja. Desta forma, cabia a ela a incumbência de construir e manter os logradouros públicos locais e, se fosse preciso, recorrer às leis caso algum popular resistisse à execução de alguma obra julgada necessária.

Conforme as Atas da Câmara, Igreja e populares deveriam se organizar em 'mutirões' e dar condições de uso aos logradouros da freguesia, conforme podemos observar no ofício do fiscal do bairro a seguir, rogava-se:

[...] q. a Cama. lhe envie na collecção de postura, igualme. participando, que com auxilio do Rvo. Vigario e Dr. Gabriel José Roiz dos Stos., que concorrerão com as despezas, conseguiu que todos os moradores capazes de trabalho fizessem no dia 19 de Dezembro findo fizessem, digo um serviço consideravel, aplanando e atterrando a rua q. segue á esquerda da Matriz, até adiante da praça do Rozario, fazendo-se uma rua transversal communicando com a estrada pa. o Rio de Janeiro, empregando-se neste trabalho sessenta e quatro mil reis; finalme. communica que o pateo da matriz acha-se embelezado com uma plantação regular de palmeiras feita á custa do mmo Dr. Roiz. dos Santos. ${ }^{200}$

Na prática o Estado era ausente, porém, sem seu conhecimento e consentimento, as obras eram impraticáveis.

O Estado também se apresentava para ratificar a escolha dos locais destinados ao uso público. Desta forma, antes que os posseiros passassem a registrar terras que poderiam ser destinadas à um futuro uso de caráter público, a união se apresentava e definia a delimitação da mesma. Em relação a essa problemática elucidam-nos as Atas da Câmara Municipal de São Paulo de 07 de setembro de 1861:

[...] o requerimento de Mel. Gomes Pereira, com família, em requerer ao Exmo Presidente da Prova. a compra do largo denominado - S. José - perto da frega. da Penha, é de parecer que se responda ao Governo que o referido terreno é um d’aquelles que já foi reservado por esta Camara pr. logradouro publico; por isso

197 . LIMA, R. C., op. cit., 1991, p.70.

198. Cf. Atas da Câmara da Cidade de São Paulo - 1852, Departamento de Cultura, Prefeitura Municipal de São Paulo, 1949, p.138.

199 . Ibidem. p.167.

${ }^{200}$.Cf. Atas da Câmara da Cidade de São Paulo - 1856, Departamento de Cultura, Prefeitura Municipal de São Paulo. 1949. p.06. 
não pode ter lugar o que requer o Suppe., pois é o único largo que existe nas immediações da povoação da Penha. ${ }^{201}$

No entanto, reservar terras para futuro uso público não revelava qualquer indício de preocupação mais séria com a organização do espaço urbano. Segundo Aroldo de Azevedo, pequenos núcleos, como a freguesia da Penha, apresentavam-se com grande irregularidade no plano e com traçados estranhos, o que a seu ver gerava "estruturas inorgânicas como as do núcleo primitivo da cidade de São Paulo. „202

Uma vez, mesmo que precariamente, definidas as terras destinadas ao uso público, a comercialização e regularização do uso das devolutas que restaram na localidade voltaram a acontecer. Foram inúmeros os pedidos de aquisição de datas de terras encontrados nas Atas da Câmara no final do século XIX. Vejamos alguns exemplos: "Reqtos. de Joaquim Anto. de Godoi e outros pedindo datas na frega. da Penha de França."203. "Outro de Pedro dos Santos pedindo uma data de terra sita na rua que segue da frega. da Penha pa. a da Con. dos Guarulhos. „204

O mesmo não se aplicava para ao antigo aldeamento de São Miguel. Só para ilustrar a desordem, para essa categoria de terra nada ainda havia sido definido e a falta de fiscalização permitia que posseiros não só invadissem as terras como se estabelecessem com lavouras já em franco desenvolvimento. Em ofício, o fiscal da freguesia, comenta que,

[...] em vir (virtude) das ordens desta Câmara foi a freguesia da Penha e em companhia de Prudencio José Rodrigues foi ao logar em que este se queixava de haverem os moradores apropriado de um terreno de servidão publica e nelle feito plantações, e verificando a exatidão do facto ali praticado, pois encontrou plantações de mandioca, canaviaes e cafezaes, intimou a um dos invasores que encontrou de nome Francisco Jose Arruda a que abrisse mão do terreno ocupado por elle, o qual nenhuma opposição fez em restituir o terreno a servidão publica mas tendo uma plantação de mandioca pedio o prazo de um anno para fazer sua colheita. ${ }^{205}$

Podemos supor que nada se resolveu e mais tarde o usucapião permitiu a regularização do uso deste solo.

De fato, temos que a promulgação da Lei de Terras de 1850 permitiu a efetivação da terra como mercadoria e isso que nos interessa, pois proporcionou grandes

201. Cf. Atas da Câmara da Cidade de São Paulo - 1861, Departamento de Cultura, Prefeitura Municipal de São Paulo, 1949, p.226.

202. AZEVEDO, Edgard de A. Vilas e Cidades do Brasil Colonial. In: Anais do Departamento de Geografia, Associação de Geógrafos Brasileiros, São Paulo. 1956. p.153.

${ }^{203}$. Cf. Atas da Câmara da Cidade de São Paulo - 1862, Departamento de Cultura, Prefeitura Municipal de São Paulo, 1949, p.98

204 . Ibidem, p.105.

${ }^{205}$. Cf. Atas da Câmara da Cidade de São Paulo - 1869, Departamento de Cultura, Prefeitura Municipal de São Paulo, 1949, p.221. 
transformações no desenvolvimento do meio urbano brasileiro e logicamente na Penha. Para Rolnik,

[...] a partir de sua promulgação, a única forma legal de posse da terra passou a ser a compra devidamente registrada. Foram duas as implicações imediatas dessa mudança: a absolutização da propriedade, ou seja, o reconhecimento do direito de acesso se desvincula da condição de efetiva ocupação, e sua monetarização, o que significa que a terra passou a adquirir plenamente o estatuto de mercadoria. ${ }^{206}$

Para as relações sócio-econômicas da Penha, o estabelecimento da propriedade privada de imediato pouco significou, já que a economia local resumia-se a culturas de subsistência. Desta forma, a valorização da terra continuou lenta e a localidade pouco interessava aos especuladores. Outro motivo foi o de que, naquele momento histórico, as terras destinadas à produção para exportação representavam melhor negócio que o investimento em regiões como a Penha.

Mesmo assim, antes que os olhos dos especuladores de terras se voltassem para regiões como a Penha, fazia-se necessário a definição mais precisa dos limites dos lotes.

Na cidade de São Paulo dos idos de 1886, originou-se a primeira normatização das posturas relacionadas à mensuração e a regularização dos lotes. A proposta básica da normatização era o alinhamento ${ }^{207}$ imediato das terras de ordem comunal e, sem dúvida, tal procedimento se apresentava como fator importantíssimo para o entendimento da organização do espaço e para estabelecimento de preços dos terrenos da cidade. O alinhamento “ganhará papel crucial ao longo do século, à medida que avança o capitalismo, cresce o valor de troca da terra, aumentam os atritos e as questões de limites entre vizinhos, entre espaço privado e o espaço público, ambos se redefinindo e precisando nos termos atuais. „208

Definir os limites e propriedades dos terrenos era fator primordial para o processo de urbanização. Sem esses limites não se poderia arruar. Segundo Martin, “o serviço de

${ }^{206}$. ROLNIK, Raquel, A cidade e a lei: legislação, política urbana e territórios na cidade de São Paulo. São Paulo: StudioNobel/Fapesp, 1997, p.23.

207. MARX, Murillo. Cidade no Brasil, em que termos? São Paulo: Studio Nobel, 1999, p.79. Para o autor, "alinhar, fazer alinhamento ou simplesmente alinhamento foi sempre estabelecer a fronteira entre o espaço público e o privado [...] De separar as áreas comuns sob a responsabilidade do senhorio direto - fábrica de capela ou câmara municipal - áreas concedidas a senhorios úteis que mantinham com o primeiro vínculo perpétuo, o alinhamento foi passando a confrontar o dono absoluto do patrimônio público e o recente proprietário particular do terreno. Mais do que os abusos de sempre, os avanços sobre o que é de todos muitas vezes descuidado como terra de ninguém, mais do que circunstâncias específicas nas localidades mais prósperas, a mudança naquela relação constituiu a causa principal de uma corrida ao alinhamento no período tratado. A rua diante de datas de chão passou a rua diante de terrenos particulares absolutamente; também a travessa, que como tal vai desaparecer. Arruar terá uma acepção mais restrita, porém fulminante quanto a seu caráter físico e ao alinhamento, desincorporado o rossio, desamortizados os bens de mão morta e, sobretudo, permitidos os loteamentos".

${ }^{208}$. MARX, M., op. cit., 1989, p.145. 
arruamento por exemplo muitas vezes encontrava casas desalinhadas, e cercas ou benfeitorias em terrenos com limites imprecisos, causando empecilhos para às obras. „209 O alinhamento, que definiu de vez os limites entre o público e o privado, proporcionou grande expectativa de valorização contínua e rápida das terras paulistanas. Tal expectativa definiu “uma demanda adicional por terra,"210 cujo único objetivo era "usufruir dos ganhos diferenciais decorrentes da valorização do solo.”211

Segundo Singer, “esta procura pode ser considerada especulativa 'pura' da terra, pois mesmo na demanda com fins de utilização (industrial, comercial, residencial, etc.) do terreno, o elemento 'expectativa de valorização futura' entra em certa medida."212 Assim, muitos terrenos foram conservados e mantidos fora do mercado na expectativa de uma futura valorização. E esta valorização sempre acabava correlacionada a instalações de infra-estruturas como, por exemplo, as vias férreas.

Para ilustrar os parágrafos anteriores, podemos citar alguns exemplos de alinhamentos na Penha que encontramos nas Atas da Câmara de São Paulo a partir de 1870:

[...] de José de SantaAnna Silva, da Freguesia da Penha, pedindo que se lhe mande dar alinhamento para a collocação d'um portão de entrada e sahida do seo terreno que já foi examinado pela comissão desta Câmara quando lá se dirigio. ${ }^{213}$ [...] do coronel Antonio Proost Rodovalho, pedindo que se lhe mande dar alinhamento em seo terreno na rua da Conceição nos fundos da Caza fronteira a Estação da estrada de ferro que também lhe pertence. ${ }^{214}$

[...] de João Cezario de Abreo [...] pedindo alinhamento para edificar uma olaria em seos terrenos junto ao ribeirão Aricanduva na [...] Freguesia da Penha. ${ }^{215}$

Podemos observar nas citações acima, pelo menos duas informações interessantes: a) a presença da linha férrea (ramal Guaiaúna-Penha da Central do Brasil) dentro da propriedade do Coronel Antonio Proost Rodovalho, como fator de valorização da terra e do seu entorno, que analisaremos no capítulo seguinte, e; b) além do estabelecimento da

${ }^{209}$. MARTIN, A, R., op. cit., 1984, p.48.

210. SINGER, Paul. Desenvolvimento Econômico e Evolução Urbana. São Paulo: Companhia Editora Nacional, 1974, p.64.

211 . Ibidem, p.65.

${ }^{212}$. Idem. Segundo o autor, "a especulação consiste, no fundo, numa antecipação das economias externas que, num prazo previsível, deverão beneficiar determinada área e deste modo valorizá-la. O curioso é que sua própria ação a auto-alimenta, já que ao ocasionar aumento do preço da terra, ela justifica uma elevação da procura especulativa, pois a valorização presente prenuncia a valorização futura. Evidentemente, este processo não pode prosseguir indefinidamente, por assim dizer, girando no vazio. O capital para especulação é limitado e quando se esgota o especulador precisa parar de comprar e começar a vender. E é neste momento que ele vai verificar se a especulação tinha base na realidade, isto é, se as vantagens relativas da área aumentaram desde a ocasião da compra."

${ }^{213}$. Cf. Atas da Câmara da Cidade de São Paulo - 1874, Departamento de Cultura, Prefeitura Municipal de São Paulo, 1949, 22/01/1874, p.21.

214. Cf. Atas da Câmara da Cidade de São Paulo - 1876, Departamento de Cultura, Prefeitura Municipal de São Paulo, 1949, 17/05/1876, p.39.

${ }^{215}$. Ibidem, 15/02/1877, p.50. 
ferrovia (nos baixos terraços), a instalação de uma olaria na várzea do rio Aricanduva que nos revela novas possibilidades de exploração das terras encontradas nos baixos terraços e várzeas. Por livre dedução, podemos supor que, uma vez definidas as áreas reservadas à instalação das vias férreas, as demais foram liberadas para o uso privado.

A instalação de vias férreas proporcionou o aumento do interesse dos especuladores imobiliários e os terrenos da região passaram a se valorizar. A comercialização de terrenos como os localizados na Penha, não tão próximos do centro da cidade de São Paulo, contribuíram para o aumento da mancha urbana paulistana.

Com a chegada da ferrovia e a crescente industrialização que se processou na cidade de São Paulo a partir da década de 1880, muitas transformações se efetuarão na região. A ferrovia facilitou a comunicação da Penha com a cidade e acabou por impor novos usos para as terras da região. Além de produtora de hortifrutigranjeiros e outros gêneros voltadas para abastecimento da cidade, o bairro também se transformou em área de lazer e turismo para a população paulistana.

A ferrovia também acabou favorecendo o crescimento urbano da Penha, pois possibilitou o aparecimento de inúmeros loteamentos para a construção de moradias para operários e demais trabalhadores da cidade de São Paulo.

Os novos moradores, principalmente imigrantes italianos e portugueses, trouxeram novos costumes que muito se distanciavam daqueles moradores antigos, advindos, sobretudo, das práticas do catolicismo penhense que, até aqui, identificamos como um dos alicerces da formação do bairro rural da Penha. No entanto, estamos conscientes de que quando eles se estabeleceram o bairro rural já dava seus últimos suspiros.

Destacamos também que as mudanças nas relações sociais, políticas e econômicas que se processariam no espaço penhense não aconteceram de forma imediata. O processo foi lento e durou do final do século dezenove até meados da década de 1940. Seria imprudente não considerar tal período uma transição.

A Penha ainda vai manter parte das velhas tradições e sua individualidade por muito tempo.

Será nessa transição (onde rural e urbano e/ou tempos lentos e tempos rápidos e/ou velho e novo se complementam e se confrontam) que embasaremos a nossa hipótese da transformação da Penha em subúrbio paulistano. Este é o tema do próximo capítulo. 
CAPÍTULO 2

Penha: um subúrbio paulistano 


\subsection{Considerações iniciais.}

Até a chegada da ferrovia, no final do século dezenove, fora a importância da religiosidade, a Penha tinha pouco a oferecer à cidade de São Paulo. Os motivos do isolamento estavam diretamente associados à distância, ao que se produzia, ao estado das vias e dos meios de transporte que tornavam difíceis as trocas.

Como já assinalado, a única via de ligação com a cidade era a antiga Estrada da Penha, que, por atravessar áreas alagadiças durante as cheias dos rios Tietê, rio Aricanduva e rio Tatuapé, apresentava-se sempre em condições precárias para os carros de tração animal ${ }^{216}$. O uso das canoas, via rio Tietê, era uma opção de transporte, mas pelas próprias características destas embarcações naquela época, pequenas e lentas e a remo, não se apresentavam nada interessantes para traslados de pessoas e mercadorias

Alias, não só o Bairro da Penha se apresentava isolado, em termos econômicos, toda a região leste da cidade de São Paulo encontrava-se na mesma condição. ${ }^{217}$ A ausência de produção para a exportação e a prática da agricultura de subsistência fazia a região desinteressante até para a cobrança de impostos, o que contribuía ainda mais para seu distanciamento da cidade de São Paulo. Somava-se a isso, o fato da região estar distante das rotas do café.

No último quartel do século dezenove, a paisagem nada mudara. A Penha continuava sendo uma capela, uma porção de casas, muitas vazias, e um pequeno equipamento comercial pontuando um topo de colina. Como já observamos, a maioria dessas casas era de agricultores que residiam no campo e somente as utilizavam nas épocas de festividades, para efetivar trocas comerciais e em ocasiões especiais, também relacionadas à religiosidade, como batizados, casamentos e enterros. Desta forma, podemos dizer que a vida do pequeno aglomerado tinha caráter intermitente.

Segundo Langenbuch, nas últimas décadas do século dezenove o aglomerado penhense se destacava pela religiosidade:

[...] grande número de casas urbanas pertenciam a agricultores que a elas acorriam apenas em dias de ofícios e festas religiosas. É de se supor que tal fato fosse comum, em maior ou menor escala, nos demais aglomerados de categoria superior. Ora, se muitos agricultores tinham casas no aglomerado, para nela se alojarem nas mencionadas ocasiões, era também grande o número de agricultores que não dispunham dêste luxo, mas que igualmente eram atraídos ao povoado

216. SANTARCANGELO, M. C. V., op. cit., 1968, p.21. De acordo com a autora, os bondes de tração animal chegavam à Penha depois de ter seus animais trocados no Marco de Meia Légua e no Brás, onde se localizava a “Cocheira dos Bondes”. Antes a população da Penha era obrigada a seguir a pé, a cavalo ou de tílburi até o bairro.

${ }^{217}$. SINGER, P., op. cit., 1974. p.20. 
com a mesma finalidade religiosa [...] A freguesia da Penha era o aglomerado que mais se distinguia neste particular, constituindo verdadeiro centro de peregrinação $[\ldots]^{218}$

Afirma Langenbuch, ao analisar a relação entre o aglomerado penhense e a cidade de São Paulo,

[...] Através de sua função religiosa, a Penha mantinha ligações muito estreitas com a Capital, tendo sido, provavelmente, o aglomerado dos arredores mais diretamente com ela relacionado $[. . .]^{219}$

Assim, acreditamos que no final do século dezenove, os laços somente se acentuavam nos períodos de festas religiosas e procissões e passado esse momento, tudo voltava ao de sempre: o velho bucolismo retornava à paisagem, as barracas de comes e bebes, de vendas de artigos religiosos e suvenirs e de jogatinas desapareciam, o comércio voltava a sua normalidade e a maioria das casas e pousadas para o atendimento dos visitantes tinham suas portas fechadas, pois seus donos retornavam às suas moradas no campo.

À época, a Penha apresentava um número muito pequeno de habitantes, segundo Languenbuch, em 1876, o aglomerado penhense possuía não mais que 1983 habitantes. ${ }^{220}$ Para se ter uma idéia de como a Penha pouco havia se desenvolvido ao longo do século dezenove, Lungenbuch apresenta os dados da população penhense no ano de 1836: 1206 habitantes, sendo 610 (51\%) brancos, 361 (30\%) pardos (caboclos, mulatos e cafuzos), 235 (19\%) negros e nenhum índio. ${ }^{221}$ O número pequeno de negros permite a suposição de que o poder aquisitivo dos moradores da região era limitado; assim, ter escravos deveria se tratar de um luxo que a maioria dos penhenses não podia sustentar.

A importância política e econômica do aglomerado era tão pequena que em 24 de maio de 1880, a freguesia de Conceição de Guarulhos foi elevada à categoria de vila e a freguesia de Nossa Senhora da Penha de França, junto com a freguesia de Juqueri, foram a ela anexadas. Somente depois de seis anos, em 3 de maio de 1886, mais por solicitação da Igreja que qualquer outro motivo, a freguesia da Penha voltou a fazer parte do município de São Paulo

Quanto ao comércio penhense também não se destacava: pequenos armazéns, casas de artigos religiosos. Havia, também, pousadas para viajantes com seus pastos para acolhimento de tropas.

Fora a religiosidade, a Penha era apenas ponto de passagem.

Os serviços prestados a viajantes e visitantes até que tinham seu destaque, pois

\footnotetext{
${ }^{218}$. LANGENBUCH, J. R., op. cit., 1971, p.52.

219 . Idem.

${ }^{220}$. Idem.
} 
garantiam rendimentos aos moradores do aglomerado. Langenbuch, ao analisar as práticas comerciais dos aglomerados paulistanos do século XIX, afirma

[...] que a prestação de serviços à circulação tenha sido uma das mais importantes, quiçá principal, em apreciável número de aglomerados, quer grandes, quer pequenos. Comércio e aluguel de animais de carga e montaria, hospedagem de viajantes, compreendendo pernoite, alimentação e fornecimento de víveres, engajamento de população urbana como tropeiros, são as principais atividades ligadas à circulação, que constituem um dos meios de subsistência [...] $]^{222}$

Quanto à prática da agropecuária local: encontrava-se praticamente alheia aos moldes do capitalismo comercial (plantation de cana-de-açúcar e café), e o lucro com a produção era insignificante. Podemos supor que a produção agropecuária da região, pelo menos até o aparecimento de transportes mais eficientes, era destinada à subsistência e ao escambo entre os moradores.

A prática agropastoril dos camponeses penhenses era favorecida pela presença de água em abundância, de solo fértil, de clima favorável e de pastagens naturais. O que permitia aos pequenos proprietários da região plantar cana-de-açúcar, algodão, vinha, trigo, mandioca, milho, café, hortaliças, entre tantos outros, e criar gado bovino, porcos, aves, eqüinos, mulas para transporte.

No mais, a localidade pouco se diferenciava das demais freguesias que compunham a cidade de São Paulo. Como podemos observar neste documento encontrado na Ata da Câmara Municipal de São Paulo de 28 de maio de 1874:

[...] que na auzencia de dados officiaes quer nos archivos desta Camara quer [...?] apenas a Camara informar pelo conhecimento que tem do municipio o seguinte: Quanto ao primeiro quesito - Quaes as superfícies cultivadas e não cultivadas? que não sendo o municipio desta capital dado a grande lavoura, mas occupandose com raras excepções, os seos agricultores no plantio de cereaes, cultivão para este fim poucos alqueires de terras, pelo que parece, attendendo a isto e a grande quantidade de terras incultas, que não ha exageração em estabelecer que apenas um decimo, quanto muito, da superfície do municipio é cultivado. Quanto ao segundo quesito - Quaes os productos das diversas culturas com relação as superficies que ellas occupão? É fora de duvida que um terço da superficie cultivada é ocupada pelo milho, seguindo-se immediatamente a mandioca, o feijão, o arros, a batata e a canna de assucar. Quanto ao terceiro quesito - Quaes os animaes dos estabelecimentos ruraes que são nelles produsidos e servem-lhes de instrumento de trabalho? São os animaes de raças bovina e cavallos os unicos que servem no municipio de instrumentos de trabalho agricola, sendo em sua quase totalidade creados no municipio. Quanto ao quarto quesito - Quaes os systemas de cultura das terras, seos processos e ferramentas agricola? Sendo a lavoura do municipio quazi esclusivamente de cereaes é o seo systema o commum e rotineiro, que começa pela derrubada, seguindo-se a queimada, preparo da terra, plantio, limpa e colheita: as terras não são estrumadas. Pouco é uzado o arado e a enxada é o instrumento geral que prepara a terra. ${ }^{223}$

221 . Ibidem, p.70.

222 . Ibidem, p.52.

223. Cf. Atas da Camara da Cidade de São Paulo - 1874, Departamento de Cultura, Prefeitura Municipal de São Paulo. 1903. p.83. Neste ano, o Governo do Estado de São Paulo solicitou à Câmara da cidade 
Para completar, outro parecer, datado de 30 de julho de 1874, esclarece que:

[...] relativamente a terrenos do municipio em que se podem estabelecer colonos é do parecer que se responda ao governo: Que não sendo terras do municipio da capital proprios para cultura do café, e sendo em geral aproveitadas para o plantio de cereaes e canna, só para esta especie de lavoura se poderão formar com vantagens colonias agricolas no mesmo municipio, e que sendo todos estes terrenos em roda da capital em zona limitada, é mui facil a condução ao principal mercado consumidor da provincia e mesmo no cazo de exportação é facil accesso ao porto maritimo de Santos. ${ }^{224}$

Em termos de manufatura, na Penha do final do século dezenove se destacava apenas produção de vinho e cerveja. ${ }^{225}$

Mesmo com a chegada das primeiras linhas de transporte público, feita por veículos de tração animal pouca coisa se alterou na relação entre a localidade e a cidade de São Paulo. Esses veículos lentos, ruidosos, caros e irregulares, começaram a atender o aglomerado a partir de 1872, mesma época em que começaram a circular por Santo Amaro, ${ }^{226}$ e se apresentaram insuficientes para melhorar vínculo com a cidade.

\section{Segundo Santarcangelo,}

[...] ela Lei Provincial de nove de março de 1871, era outorgada a exploração do transporte sobre trilhos ao engenheiro Nicolau Rodrigo de França Leite, que a transferiu à Companhia Carris de Ferro de São Paulo. A primeira linha de diligências sobre trilhos de ferro ia do Largo do Carmo à Estação da Inglesa. A inauguração dessa linha de bondes do Brás deu-se a primeiro de julho de 1877, com os carros ornamentados com bandeirolas e altos convidados. Surgiram duas linhas a vapor. Uma para o Ipiranga e outra para a Vila Mariana. A do Ipiranga teve curta duração, a segunda estendeu-se até Santo Amaro. Nessa época, só existiam, sobre trilhos, duas formas de transporte: - bondes alimentados a vapor (Santo Amaro) e bondes puxados por parelhas de burros, que entraram em circulação a partir de doze de outubro de 1872. Em 1889, já funcionavam várias linhas por tração animal. Quatro companhias exploravam esse transporte. A de Rudge Ramos, foi a que obteve autorização para extensão da linha Penha. ${ }^{227}$

Com a chegada da ferrovia esse meio de transporte entrou em decadência e desapareceu na localidade. ${ }^{228}$

uma pesquisa que permitisse fornecer um parâmetro geral da produtividade agropecuária no município.

224 . Ibidem, p.112.

${ }^{225}$. BRUNO, E. S. op. cit., 1984, p.690. Segundo o autor, desde 1850 já se falava da cerveja da Penha; “em 1850 os estudantes da Academia, quando iam cear em um dos dois restaurantes paulistano, ou mesmo apenas tomar um copo de cerveja da Penha [...]"

${ }^{226}$. LOPES, M. B. P. O. Pequena história dos transportes públicos de São Paulo. Museu CMTC dos transportes públicos, $2^{\circ}$ ed., São Paulo, 1985. Segundo a autora, "os primeiros registros da organização dos transportes públicos em São Paulo datam de 1865, quando foram regulamentados os serviços de tílburis (veículos de duas rodas puxados por um cavalo, ou carruagem de quatro rodas puxada por uma parelha) [...] em 21 de agosto de 1865, o italiano Donato Severino regulamentou por conta própria o uso de tílburis, transformando-os em carros de praça com tabela de horários e preços. Dois anos depois, as leis municipais regulamentaram a profissão de cocheiro [...] Para ir do centro à estação Norte Igreja da Luz, Igreja da Consolação, Arouche ou riacho Lava-pés, o preço das viagens era a metade daquele cobrado para lugares mais distantes, como a Várzea de Santo Amaro, Caminho da Penha ou cemitério da Consolação [...] Para viagens mais distantes, como Santo Amaro ou Penha, usava-se os carros de boi [...]" p.18.

${ }^{227}$. SANTARCANGELO, M. C. V., op. cit., 1968, p.21.

${ }^{228}$. BRUNO, E. S. op. cit., 1984, p.582. 
Para ilustrar o parágrafo anterior temos interessante citação de Hadfield encontrada no trabalho de Richard M. Morse:

O número de velhas carroças ou carros com duas rodas inteiriças de madeira [na cidade de São Paulo] puxados por ‘juntas' de bois de acôrdo com o pêso a ser transportado, e a constante passagem dos mesmos e de burros e cavalos... indicam a natureza dos meios de transportes que existiam antes da abertura da estrada de ferro [...] [os agricultores] se agrupavam junto a lojas ou armazéns nas ruas em que se realizam seus negócios, descarregam as mercadorias e uma certa porção dos animais é carregada de novo e levada aos seus respectivos destinos. ${ }^{229}$

As terras da região não entraram de imediato no processo especulativo que já se acelerava em outras áreas da cidade de São Paulo. Voltaremos a falar desse fenômeno mais adiante.

Nos primeiros anos da ferrovia, o isolamento socioeconômico começou a diminuir, pois reforçou a condição de área tributária da cidade de São Paulo (fornecimento de produtos primários e mão-de-obra). No entanto, a região continuou fisicamente separada da cidade.

Tal situação também contribui para a formulação da hipótese de que a região vivenciou uma condição de subúrbio. Vamos aprofundar nossa análise partindo do estudo da chegada da ferrovia no bairro.

\section{$\underline{2.2}$ A chegada da ferrovia}

A ferrovia surgiu subseqüente à invenção da máquina a vapor, na esteira de grandes avanços tecnológicos que se processaram na Grã-Bretanha na virada do século dezoito para o dezenove.

A ferrovia chegou ao Brasil a partir da década de 1850, após a sanção da Lei Imperial $n^{\circ}$. 641 que concedia grandes privilégios e garantias de lucros, a partir dos juros cobrados, aos construtores que se interessassem pela empreitada. ${ }^{230}$

No Estado de São Paulo, a primeira ferrovia - a São Paulo Railway - foi inaugurada em 1867, ligando o porto de Santos à cidade de Jundiaí.

O intenso comércio de café e os lucros que este proporcionava passaram a exigir progressivas melhorias na infra-estrutura brasileira. E não era sem tempo, as dificuldades impostas pelas distâncias e pelas diversidades geográficas tornavam o transporte de

${ }^{229}$. MORSE, R. M., op. cit., 1970, p. 191 Apud HADFIELD, Willian. Brazil and the River Plate in 1868. London: Bates, Henry e Co., 1869, p.69-70.

230. MATOS, Odilon Nogueira de. Café e Ferrovias: A evolução ferroviária de São Paulo e o desenvolvimento da cultura cafeeira. $2^{\mathrm{a}}$ ed., São Paulo: Editora Sociologia e Política, 1974, p. 51. 
mercadorias, de pessoas e a comunicação nacional muito lenta e dispendiosa. Assim, a ferrovia passou a ser uma necessidade mais que imediata para o progresso e o aumento dos lucros nacionais naquele período. ${ }^{231}$ Os principais reflexos desta nova conjuntura são presenciados em cidades como São Paulo.

O primeiro trecho de ferrovia no Brasil foi inaugurado em 30 de abril de 1854. Possuía aproximadamente 14,5 quilômetros e ligava a Praça Mauá à estação Fragosa, no Estado do Rio de Janeiro. Era parte de um projeto que buscava ligar o vale do rio Paraíba, em São Paulo, ao Estado do Rio de Janeiro e estava diretamente associado às rotas dos tropeiros e aos portos que serviam ao comércio do café. ${ }^{232}$ A chegada da ferrovia tinha como objetivo aposentar o defasado transporte de café no lombo das mulas e burros.

Segundo Langembuch, a ferrovia aparece como instrumento de reorganização dos arredores paulistanos:

Antes de mais nada provocou o colapso do antigo sistema de transporte e das atividades a êle relacionadas. Por seguir trajetos diferentes das antigas estradas 'ordinárias' provocou uma relativa desvalorização de áreas beneficiadas por aquelas, desvalorização esta que abrangeu grande número dos aglomerados preexistentes. Pelo mesmo motivo, a ferrovia ocasionou um desvio de rotas, valorizando estradas 'ordinárias' transversais. Valorizou as áreas que passou a servir. Os 'povoados-estação' cresciam enquanto os aglomerados apartados da linha, de um modo geral, estagnavam. ${ }^{233}$

Esse quadro descreve o que se processava em São Paulo e suas cercanias naquele período e revela que na cidade de São Paulo, as transformações se processaram de forma descompassada: enquanto as áreas cortadas pela ferrovia Santos-Jundiaí apresentavam-se atraentes para os interesses capitalistas, a porção leste, onde encontramos a Penha pouco sentia a força desse movimento.

No entanto, a inauguração da ferrovia representou um grande passo para atrair esses interesses para a região.

A Penha passou a ser servida pela ferrovia com a inauguração em 06 de novembro de 1875 do trecho São Paulo-Mogi das Cruzes. O trecho fazia parte da ferrovia de ligação das cidades de São Paulo e Rio de Janeiro e sua obra ficou sobre a incumbência da Companhia São Paulo e Rio de Janeiro.

231. BEM, Silvia Ferreira. Contribuição para estudos das estações ferroviárias paulistas. Dissertação de Mestrado apresentada à FAU-USP, vol.I, 1998, p.18-20. Segundo a autora, "o café chegou ao país em torno de 1820, penetrando terras paulistas nos anos de 1830, através de Bananal e Areias, no Vale do Paraíba [...] alastrou-se logo oferecendo uma produção cada vez mais intensa para escoar com rapidez e cuidados e exigindo vencer grandes e variadas distâncias até os pontos de consumo e exportação [...] o volume transportado implicava diretamente no valor monetário da produção."

${ }^{232}$. Ibidem, p.23.

${ }^{233}$. LANGENBUCH, J. R., op. cit., 1971, p.129. 
O decreto que permitiu a criação e organização de tal companhia foi ratificado em 02 de março de $1872{ }^{234}$ Nele também constava o objetivo de ligar a capital paulista ao povoado de Cachoeira no Vale do Paraíba, passando pelo entorno rural paulistano, inclusive na localidade estudada, e pelas cidades de Mogi das Cruzes, Jacareí, São José dos Campos, Caçapava, Taubaté, Pindamonhangaba, Guaratinguetá e Lorena, completando um total de 231 quilômetros de estrada de ferro. ${ }^{235}$ No povoado de Cachoeira os trilhos seriam interligados aos trilhos da ferrovia D. Pedro II, que vinha do Rio de Janeiro.

A estrada de ferro que ligava São Paulo ao Rio de Janeiro primeiro ficou conhecida pela denominação Estrada do Norte de São Paulo, por cortar o norte da província paulista. Por não apresentar lucros financeiros até 1888, foi resgatada em 1890 pelo governo Federal Provisório e então incorporada à Estrada de Ferro Central do Brasil, denominação que a ferrovia D. Pedro II recebeu após a proclamação da República. ${ }^{236}$

Nesta pesquisa, foi possível constatar que a implantação da ferrovia na Penha exigiu a desapropriação de alguns terrenos.

Como vimos anteriormente, quando estudamos a definição do uso das várzeas na Lei de Terras de 1850, os espaços indisponíveis para posse e que tinham a finalidade de uso público posterior, não foram suficientes para a implementação da ferrovia. Alguns terrenos, que haviam sido concedidos e regularizados anteriormente, tiveram que ser readquiridos pelo Estado. Segundo Egydio Martins, coube ao Dr. Clemente Falcão de Sousa Filho, superintendente da Estrada de Ferro do Norte, "tratar das desapropriações das casas e terrenos que fossem julgados necessários para, no local dos mesmos, ser feita a linha da referida estrada". ${ }^{237}$ Na Penha foram desapropriados os terrenos de Miguel Jacó e de Antonio Galvão e a pedreira dos filhos do Dr. Gabriel José Rodrigues dos Santos. $^{238}$

${ }^{234}$. BEM, S. F., op. cit., 1998, p.39. Segundo a autora, “o contrato da Companhia São Paulo - Rio de Janeiro registrou a concessão, por parte da província, de privilégio para a construção da estrada até Cachoeira e respectivo uso pelo prazo de noventa anos; [...] A concessão, bem como os estudos realizados, foram adquiridos pela Companhia por 250:000\$000 de réis. A fiança do Governo Imperial sobre a garantia de juros, concedidos pela província, possibilitaram à companhia um empréstimo de 600.000 liras, com taxa de 6\%, junto à praça de Londres, tornando possível abreviar a data dos serviços para a concretização da estrada."

${ }^{235}$. Idem. Conforme a autora, os trilhos alcançaram as cidades de Jacareí, São José dos Campos, Caçapava e Taubaté em 1876 e Pindamonhangaba, Guaratinguetá e Cachoeira no ano de 1877.

${ }^{236}$. Idem.

237. EGYDIO MARTINS, A., op. cit., 2003, p.433-434.

${ }^{238}$. Idem, segundo Antonio Egydio Martins outras desapropriações aconteceram: "Na Freguesia do Brás: casa e terreno de Antônio da Silveira Caldeira; casa e terreno do Capitão Messias Egídio dos Santos; cercado de José Júlio; terreno de Manuel Egídio dos Santos (Casa Pintada); casa e chácara do 
No contrato entre a província e a Companhia São Paulo e Rio de Janeiro, faixas de terras ao longo das margens das vias férreas deveriam ser preservadas pelo prazo de noventa anos, no entanto, partes dessas já haviam sido ocupadas e, portanto deveriam ser repassadas à Companhia. ${ }^{239}$

Uma vez definido por onde passariam as estradas de ferro, as demais áreas da localidade ficaram livres para a ocupação. Na Penha do final do século dezenove o uso variou muito: plantação e criação de animais; produção de barcos; instalação de olarias e

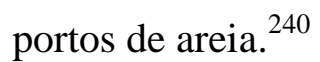

A ferrovia proporcionou não só a proliferação de aglomerados rurais e cidades como também significativas modificações na infra-estrutura urbana e na fisionomia da paisagem dos lugares por onde passava. É importante destacar que tais modificações variavam de lugar para lugar e geralmente estavam associadas a conveniências e aspirações de cada localidade. $^{241}$

Assim, como meio de transporte de pessoas e mercadorias, a ferrovia tornou-se importante agente reorganizador do espaço paulistano. Sua implementação resultou em: alterações nos traçados dos antigos caminhos; alteração nas rotas e na tipologia dos meios de comunicação com a cidade; nova configuração dos aglomerados urbanos; ocupação de novas áreas e ampliação dos limites da cidade; necessidades de novas infra-estruturas como iluminação pública e calçamento de vias; com a possibilidade e intensificação do trabalho distante de casa, proporcionou mudança na rotina de vida dos moradores; deslocamento de serviços e descentralização das funções antes atribuídas somente ao centro da cidade; facilitou a especulação imobiliária e a valorização da terra como mercadoria; representou um importante agente de mudanças no bojo das relações sócioespaciais e econômicas das localidades por onde adentrava.

Capitão Messias Egídio dos Santos; chácara dos filhos de Joaquim Manuel Rodrigues; casa e terreno do Tenente Joaquim Gomes de Assunção; quintal e cultivo de João Ribeiro de Sousa e chácara de Francisco de Siqueira Andrade; terreno de Tomé do Nascimento Silva e outro (Tatuapé) [...]”

${ }^{239}$. Na Penha, essas faixas foram preservadas até meados do século vinte, quando foram assim utilizadas: a margem esquerda, no sentido de quem vai para o centro da cidade, serviu para a expansão da linha Leste-Oeste do Metrô paulistano e de todo o equipamento que a compõe (trilhos, estações, passarelas e terminais de transportes coletivos e táxis) na década de 1980, e para a implementação da Avenida Radial Leste que corta a região desde a década de 1970; quanto a margem direita, no mesmo sentido, foi utilizada também para a instalação do equipamento do Metrô (passarelas, terminais de ônibus e táxis), para implantação de uma via rente à linha para o fluxo dos veículos até a estação Penha do Metrô, Rua Alvinópolis, e para o lazer com campos de futebol, pistas de cooper e equipamento mínimo de lazer e até um piscinão anti-enchentes (entre as estações de Metrô da Penha e da Vila Matilde). Configuração parecida pode ser encontrada nos arredores da estação Vila Matilde do Metrô.

240. Cf. Atas da Câmara Municipal - 1877, Departamento de Cultura, Prefeitura Municipal de São Paulo, 1948, p.50. Conforme petição de João Cesário de Abreo solicitando “[...] um alinhamento para edificar uma olaria em seos terrenos junto ao ribeirão Aricanduba [...]" 
Não é intenção deste trabalho analisar toda a gama de conseqüências acima citadas. Apenas serão destacadas aquelas que se apresentaram importantes para a configuração do espaço penhense. No entanto salientamos que, embora a ferrovia tenha sido fator preponderante para as modificações que ocorreram na antiga configuração espacial do aglomerado da Penha, não explica tudo. Trabalharemos outros elementos modificadores da paisagem sócio-espacial no decorrer do capítulo.

A chegada da ferrovia na Penha, de imediato causou certo desequilíbrio, pois muitos dos comerciantes que estabeleceram suas atividades econômicas vinculadas a viajantes e tropeiros que transitavam pela Estrada da Penha entraram em decadência. Segundo Bruno,

[...] as estradas de ferro se refletiram sobre o sistema de equilíbrio e especialização entre as zonas e os bairros da cidade. Em 1877, com a ferrovia para a zona norte da província, ligando São Paulo com o Rio de Janeiro, aconteceu o mesmo que ocorrera em outros quando se construiu a São Paulo Railway: perderam muito de sua importância e algumas feições mais características. Já em 1880 era pequeno o movimento de tropas e de carros nos caminhos do Rio de Janeiro, de Santos e de Jundiaí. Suas vendas de beira de estrada quase todas tinham desaparecido. E o próprio comércio de localidades como a Penha, o Ó, o Ipiranga, São Bernardo, decaíram de modo pronunciado, desde que não contaram mais com aquelas tropas e aquêles viajantes passando para cima e para baixo. ${ }^{242}$

Mas isso era apenas um dos primeiros sinais do que a ferrovia significaria para a Penha e a cidade nas décadas seguintes.

Segundo Bruno, as estradas de ferro representavam desenvolvimento econômico e o crescimento da cidade. Não somente em relação ao comércio, que passava a ser articulado através de um sistema bem mais moderno que os antigos caminhos e o transporte no lombo das mulas, como em relação à formação e a localização das fábricas que começavam a se desenvolver na cidade. Para Bruno,

[...] foram as estradas de ferro que valorizaram certas várzeas então desprezadas, fazendo com que em suas terras se edificassem bairros operários que se integraram no corpo urbano. Para facilitar aliás ao comércio e à indústria da cidade os seus serviços de importação e exportação chegou a haver em São Paulo, a partir de 1895, uma 'alfândega sêca', entre os bairros do Brás e do Pari. Uma espécie de prolongamento da de Santos. ${ }^{243}$

As vantagens do uso do trem eram muitas: transportava com maior rapidez, exigia menos mão-de-obra, contribuía para conservar os produtos e elevava muito a taxa de acumulação de produtores de café. Segundo Martin, esses fatores contribuíram para a extinção do trabalho escravo e garantiram ainda maior valorização das terras por onde as

${ }^{241}$. MATOS, op. cit., 1974, p.62.

${ }^{242}$. BRUNO, E. S. op. cit., 1984, p.1055.

${ }^{243}$. Ibidem, p.1062. 
ferrovias passavam, principalmente onde se estabeleciam as estações de embarque e desembarque. $^{244}$

Mesmo antes da inauguração da ferrovia e da Estação Carlos de Campos, as possibilidades do aproveitamento econômico dos terrenos próximos a ela já se intensificavam no bairro. Segundo Atas da Câmara de São Paulo de 28 de agosto de 1873, “João Cesário de Abreo \& CA. que tem negocio de seccos e molhados na estrada de ferro, que se negão ao pagamento [de impostos] allegando serem fornecedores da mesma estrada."245

Atender as necessidades dos trabalhadores da ferrovia se apresentava como possibilidade de ampliação e diversificação de lucros para os moradores por onde a estrada de ferro passava. Pelo que podemos observar, era até uma atividade incentivada pelo Estado.

Tal aproveitamento não é nenhum indício de que os moradores da localidade estavam preocupados com a futura valorização destes espaços, no entanto, dá para perceber que havia certa compreensão das possibilidades econômicas que estavam se estruturando.

Na Penha, os trilhos da Central do Brasil primeiro foram assentados sobre as várzeas de dois tributários do Rio Tietê, os rios Aricanduva e Guaiaúna ${ }^{246}$, local onde foram instaladas as duas estações Carlos de Campos, na várzea de contato entre os dois rios, Vila Matilde, na várzea do rio Guaiaúna. Ambas, por estarem mais próximas do núcleo embrionário da Penha, mereceram maior atenção nesta dissertação.

A estação ferroviária de Carlos de Campos recebeu inicialmente o nome de Guaiaúna $^{247}$, está localizada a 735 metros de altitude, foi inaugurada em 06 de novembro de $1875^{248}$ e afastada aproximadamente oito quilômetros a leste do marco central da cidade de São Paulo. Já, a estação Vila Matilde é um pouco mais recente, inaugurada em

${ }^{244}$. MARTIN, A. R., op. cit., 1984, p.62.

${ }^{245}$. Cf. Atas da Câmara Municipal - 1873, Departamento de Cultura, Prefeitura Municipal de São Paulo, 1948, p.182.

${ }^{246}$. Nos documentos cartográficos antigos e atuais é muito comum encontrar esse rio, que hoje não passa de um canal de esgoto, com a denominação de córrego Rincão.

247. FERROVIAS DO BRASIL. Carlos de Campos (antiga Guaiaúna). Disponível em <http://www.estacoesferroviarias.com.br/c/carloscampos.htm>. Acesso em: 20 set. 2006. A estação Guaiaúna (caranguejo negro na língua guarani) foi rebatizada de Carlos de Campos em 18 de novembro de 1933.

${ }^{248}$. BONTEMPI, S., op. cit., 1969, p.103. BEM, S. F., op. cit., 1998, p.267. Junto com as estações Roosevelt, Itaquera e Guaianases. Importante informar que a autora confundiu as estações Guaiaúna-Penha com a já desaparecida estação da Penha, do extinto Ramal Penha, inaugurada em 1876. Assim, a data que ela confere à inauguração da Estação Guaiaúna, 02 de agosto de 1894, não confere com os documentos encontrados nesta pesquisa. 
19 de agosto de 1921, está localizada a aproximadamente 11 quilômetros do mesmo marco central e a 739 metros de altitude. Conforme Mapa 2 e fotos a seguir.

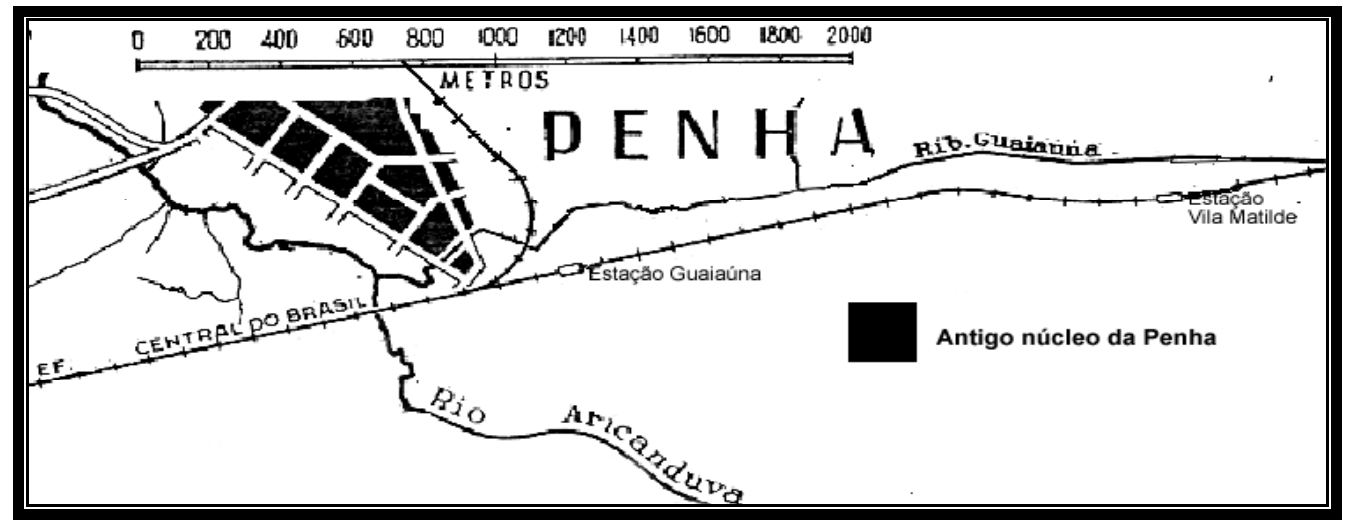

Mapa 2 - Estações da Guaiúna e Vila Matilde - década de 1920. Fonte: AZEVEDO, E. A., op. cit., 1945, p.76 (Adaptação: Edson Penha de Jesus)

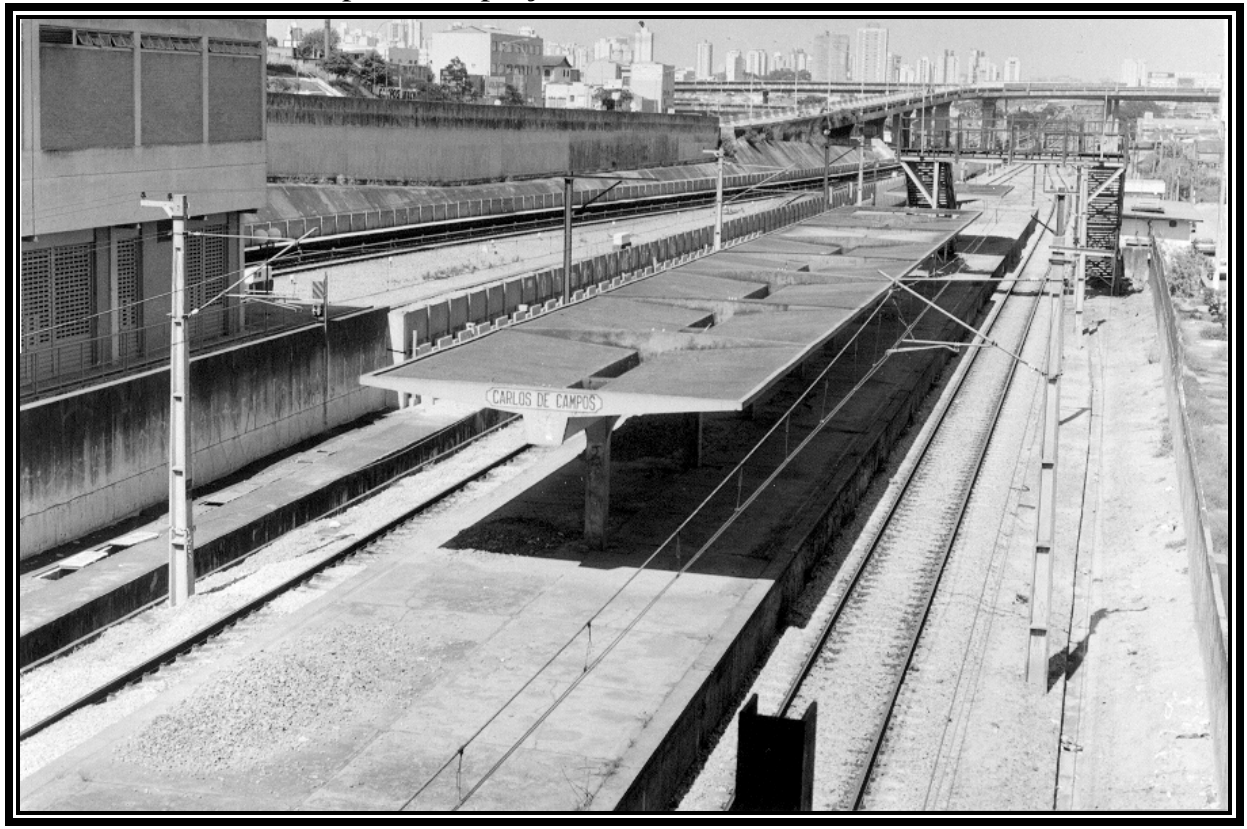

Estação Carlos de Campos em 2002, - Atualmente desativada, ao lado da estação de Metrô Penha (Foto: Edson Penha de Jesus - 2002) 


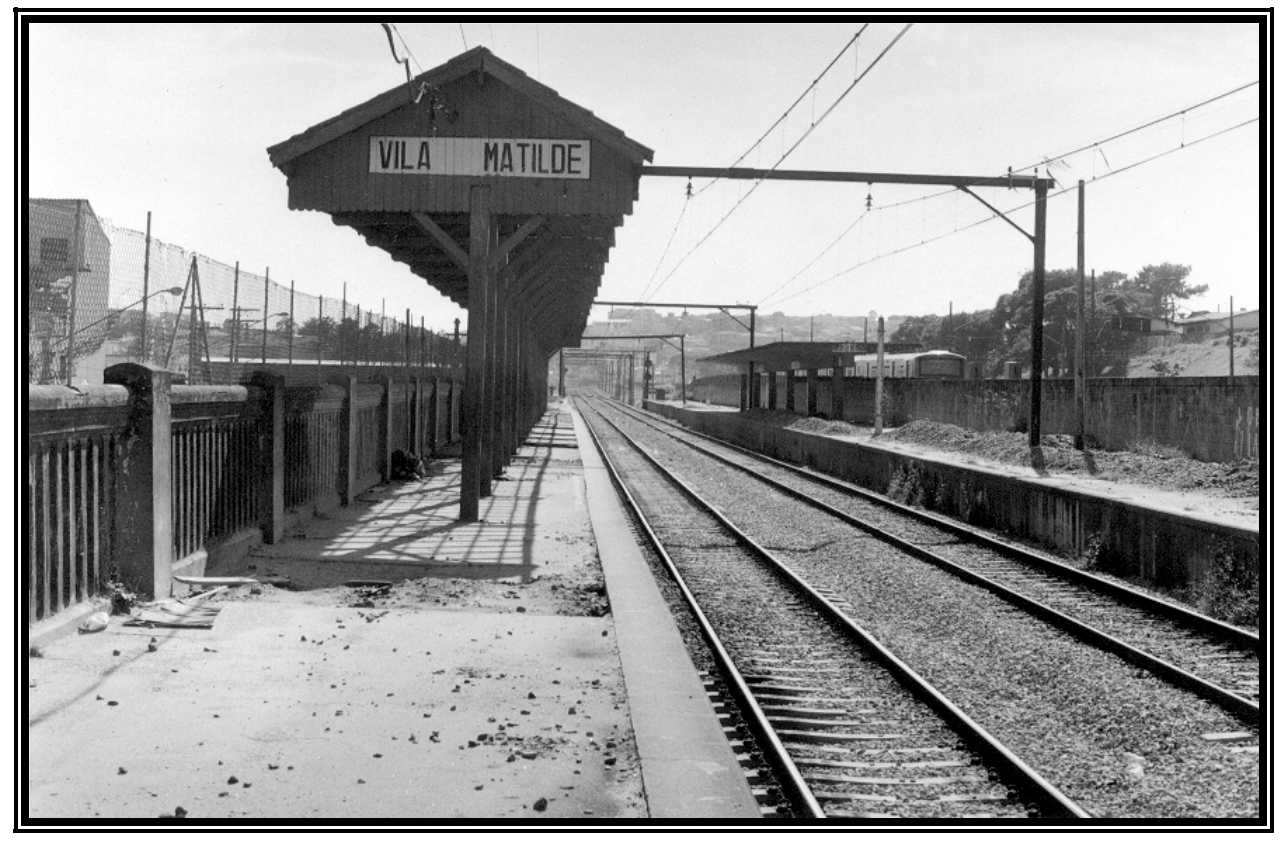

Estação Vila Matilde em 2002 - Atualmente Desativada e abandonada, ao lado a linha do Metrô LesteOeste. (Foto: Edson Penha de Jesus - 2002)

Da estação ferroviária Carlos de Campos partiu o Ramal da Penha. Esse tinha aproximadamente um quilômetro. Iniciava-se logo após a Estação, fazia uma curva para o norte e subia aproximadamente trinta metros de inclinação em direção ao topo da colina da Penha. Seu ponto final era a Estação da Penha que se encontrava aproximadamente a 150 metros das portas da antiga matriz de Nossa Senhora da Penha de França.

A construção do Ramal da Penha era justificada pelo grande fluxo de romeiros em finais de semana e durante as festividades na localidade.
O ramal chegou à porta da matriz em $1876^{249}$ (a estação ficando a aproximadamente uns 50 metros da mansão dos Rodovalho) e foi articulado aos demais meios de transportes da localidade.

249. Cf. Atas da Câmara da Cidade de São Paulo - 1875, Departamento de Cultura, Prefeitura Municipal de São Paulo. 1903. p.93-94. O trâmite do processo de instalação do ramal citado começou com uma petição de Ernesto Mariano da Silva Ramos direcionada ao Governo Provincial, datada de 05 de agosto de 1875, solicitando que: “[...] se officie ao Emo. Snr. Presidente da Provincia fazendo lembrar a conveniencia de ramal em condições de rodagem da estação da Penha na estrada de Ferro do Norte a Freguesia do mesmo nome, e não podendo ser feita as custas da municipalidade não só porque o estado actual de seo cofre como os promissos que tem contrahido digo, como os compromissos que tem contrahido não permittem, mas ainda por que sendo os ramaes da estrada de ferro da competencia do Governo que garantindo seos capitaes deve procurar todos os meios de desenvolver suas rendas. Devido conferir a Companhia [São Paulo e Rio de Janeiro de Estrada de Ferro] grande lucro com esse ramal para onde poderá estabelecer trens de suburbio a vista da affluencia de passageiros que há para aquella Freguezia da Penha principalmente em occasiões de festa, julgo que depois de examinada a melhor vereda da estação á freguezia e competentemente orçada em despeza, seja a mesma Companhia autorizada e fazer esse ramal talves com tempo de já ser utilizada para a próxima festa de outubro digo festa de 8 de Setembro". Como resposta, um documento do "Exmo. Governador, de 4 do corrente, declarando que tendo o Governo de mandar abrir uma estrada que 
No Mapa 3 podemos observar o traçado da Central do Brasil e do Ramal da Penha, assim como a localização das respectivas estações: Guaiaúna e Penha. É possível observar a outra importante via de ligação entre e a Penha e a cidade de São Paulo, a antiga Estrada da Penha que já em 1897 recebia o nome de Avenida Intendência. Nota-se ainda a pequena malha urbana da localidade e o quanto o topo central se encontrava isolado.

communique a povoação da Freguezia da Penha com a estação de estrada de ferro do Norte, haja a Camara de dar parecer sobre a utilidade e desapropriação dos terrenos, que devam ser occupados." Um dos diretores da campainha ferroviária São Paulo e Rio de Janeiro de Estrata de Ferro era o Cel. Antonio Proost Rodovalho. 


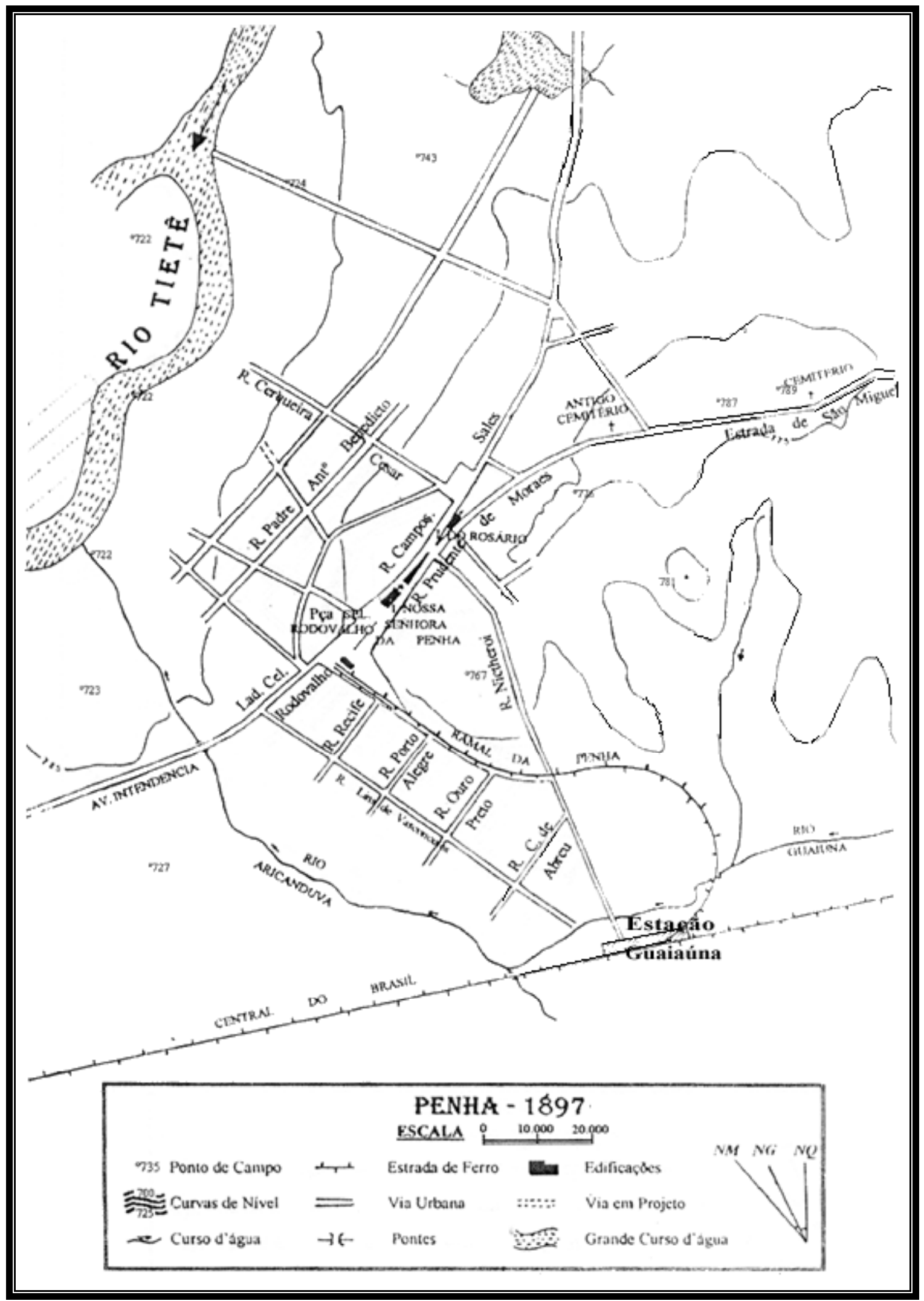

Mapa 3 - Fonte: Planta da cidade de São Paulo (planta geral da capital), org. Gomes Cardin, 1:20.000, 1897. A escala e as curvas de nível foram adaptadas da Carta da Penha de França (indicações diversas), índice de Nomenclatura: SF-23-Y-C-V1-2-NE-B, São Paulo-SP, escala 1:10.000, 1981, org. EMPLASA (Organização e simplificação: Edson Penha de Jesus) 
Podemos supor que a chegada da via férrea Central do Brasil poderia facilmente desviar o fluxo de pessoas da porção central da localidade para as cercanias da estação Guaiaúna, o que poderia resultar numa possível desvalorização das propriedades localizadas na colina. Nesse raciocínio, poderíamos supor ainda que, ao lado da estação Guaiaúna, outro centro comercial poderia ter se desenvolvido. Tal condição proporcionaria um novo arranjo para a configuração espacial da localidade. ${ }^{250}$ Essas suposições se justificam graças ao conceito de povoado-estação tão bem desenvolvido por Langenbuch. $^{251}$

A criação do Ramal da Penha foi resultado da importância histórica do aglomerado para a cidade de São Paulo e apenas foi mais um fator que contribuiu para o fortalecimento de sua centralidade. No entanto, isso não quer dizer que as terras da Penha não poderiam alcançar valor ainda maior. Certamente foi esse o pensamento daqueles que detinham terras próximas à igreja.

Assim, preocupados em valorizar ainda mais suas terras, os proprietários locais, entre eles estava a Igreja, buscaram fortalecer a porção central da localidade mantendo seus negócios no topo da colina. Não precisava muita mobilização para isso, já que todos sabiam que em épocas de chuva, a várzea do rio Guaiaúna ficava praticamente intransitável. O resultado de tal estratégia pode ser constatado nos dias atuais: a porção central concentrando importante equipamento comercial, chegando até a acolher um shopping e, em volta da antiga estação ferroviária Carlos de Campos, nenhuma estrutura comercial além de uma pequena concentração de camelôs e uma feira livre no domingo.

Outra evidência da preocupação que esses proprietários tinham com a valorização da terra, é uma petição de Cel. Antonio Proost Rodovalho, datada de 15 de maio de 1876, “[...] pedindo que se lhe mande dar alinhamento em seo terreno na rua da Conceição nos fundos da caza fronteira a estação de Ferro que também lhe pertence."252 Como já foi dito, o termo alinhamento está diretamente associado à idéia de estabelecer limites mais

${ }^{250}$. BEM, S. F., op. cit., 1987, p.305. De acordo com a autora, o aparecimento de estações ferroviárias “[...] promoveram deslocamento de serviços e uma conseqüente descentralização de funções urbanas. Os edifícios das estações tornaram-se pontos muito atraentes e definiram um novo personagem do cenário - os carroceiros transportadores de carga, em freqüente circulação pelas ruas, rumo às plataformas do trem, representando fisicamente, em especial na capital, o tempo novo iniciado e anunciado pelo trem de ferro."

${ }^{251}$. LANGENBUCH, J. R., op. cit., 1971, p.104.

252. Cf. Atas da Câmara da Cidade de São Paulo - 1876. Departamento de Cultura, Prefeitura Municipal de São Paulo. 1948, p.39. 
claros para os terrenos e diferenciar espaço público de privado. Era o reconhecimento definitivo e oficial da área da gleba para um possível negócio. ${ }^{253}$

Outra questão interessante de se observar é que o ramal foi instalado na propriedade do Cel. Antônio Proost Rodovalho.

Após a desativação do Ramal da Penha as terras voltaram para as mãos do antigo dono e, após seu falecimento e de sua esposa, o terreno foi deixado como doação para a Igreja. Neste terreno estabeleceu-se a Chácara dos Padres, com convento e residências de religiosos, e depois, no final da década de 1940, grande parte desta área foi loteada com a denominação de Vila Santo Afonso. Tal loteamento foi justificado pela necessidade de se arrecadar fundos para a construção da nova Matriz de Nossa Senhora da Penha de França.

Um esclarecimento se faz necessário: o Cel. Rodovalho pode ser considerado um representante do que Morse classificou como “coronelismo urbano", isto é, mutação urbana da figura do antigo coronel da política rural brasileira. Segundo Morse, o coronel rural teve período áureo entre 1890 e 1920 (após a Proclamação da República) e era considerado um chefe político que “manipulava eleições, exercia pressão para determinar os percursos das estradas de ferro de modo a favorecer suas terras e retribuir como pai magnânimo a lealdade de seus eleitores”. ${ }^{254}$

Segundo Morse, com o crescimento das cidades, a política rural tradicional começou a sofre mutação e esse tipo de coronel passou a atuar nas cidades e se tornou elemento importante na estruturação do urbano também. Depois, com a revolta paulista de 1932 esse tipo de líder político, ao aliar-se ao movimento reformista, se modernizou; no entanto, a partir de 1945, com o advento do Estado Novo esse tipo de político se enfraqueceu e praticamente desapareceu.

O Cel. Rodovalho foi uma das pessoas mais influentes na virada do século dezenove para o vinte e assumiu vários cargos de importância na época. Só pelos cargos que ocupava dá para entender como conseguiu a criação do Ramal da Penha. Entre esses cargos: dirigiu a Companhia São Paulo - Rio de Estrada de Ferro e a Companhia de Estradas de Ferro Ituana em 1875; em 1889 foi presidente da Caixa Econômica e Monte do Socorro da corte em São Paulo; fundou a Associação Comercial de São Paulo em 7 de

253. MARX, M., op. cit., 1999, p.79-80. Segundo Murillo Marx, alinhar constituirá, “[...] uma preocupação séria do empreendedor para cortejar o interessado na aquisição de um lote, para satisfazer as expectativas de sócios e financiadores quanto à relação áreas comercializáveis/áreas de acesso $e$ serviços; preocupação séria, antes mesmo de atender ao controle do governo local digno do nome, para deixar claramente estipulado qual seu ganho pelos direitos que lhe são devidos na transação. Como as outras linhas do desenho de um negócio imobiliário, esta importa; mais do que as outras, esta decide." 
dezembro de 1894; foi presidente da Câmara Municipal nos anos de 1873, 1896, 1897, 1898 e 1899 onde desenvolveu projetos para a regularização do transporte público paulistano; ainda foi investidor do ramo de papel (CIA Melhoramentos) de cal e cimento, de água, de alumínio e de terras. ${ }^{255}$

Graças aos vários negócios e à atuação em várias instituições públicas, o Cel. Rodovalho colecionou amigos. E fez de sua residência, na Penha, um ponto de encontro de empresários e da elite econômica da cidade. ${ }^{256}$ Mais um bom motivo para entender como o empreendimento Ramal da Penha tornou-se realidade.

A criação deste ramal, que funcionou até 1907, favoreceu ao desenvolvimento do Bairro da Penha, fortaleceu os interesses econômicos locais, confirmou sua condição de subcentro (de convergência regional) e trouxe grandes benefícios à igreja (maior afluxo de pessoas e arrecadação).

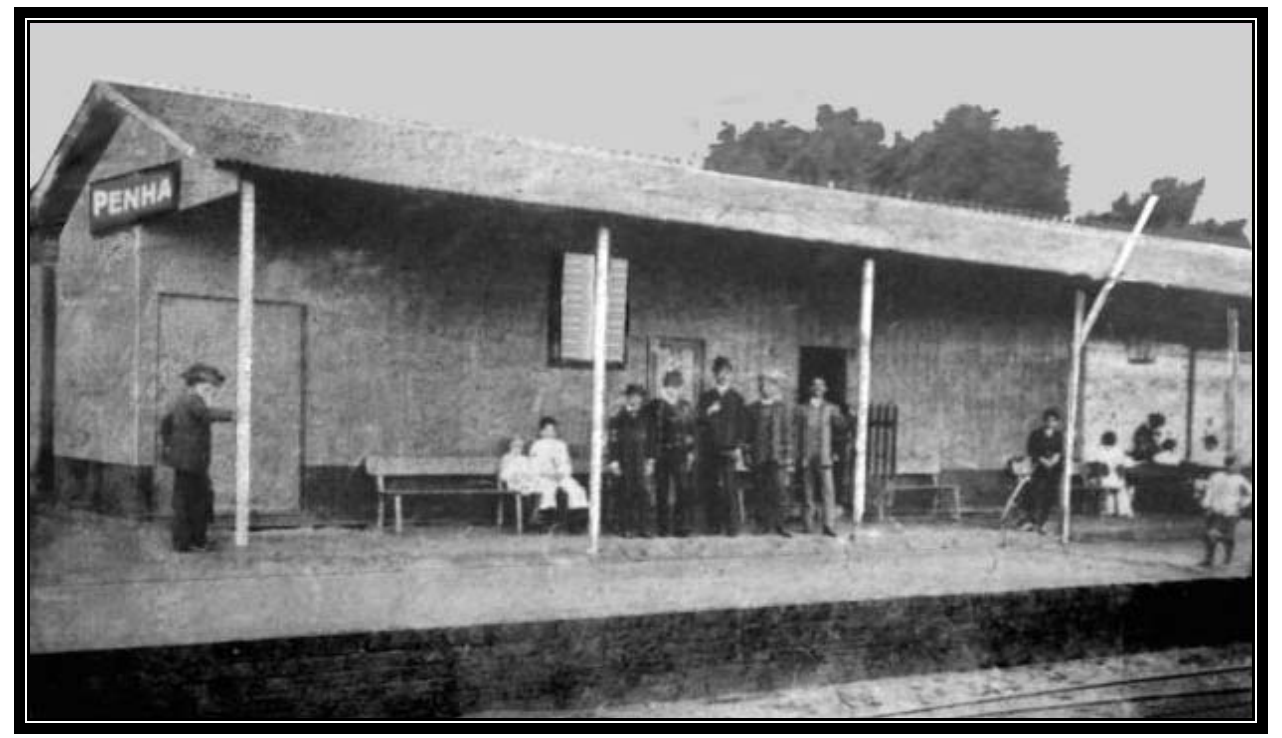

Estação Penha em 1906, ponto final do Ramal da Penha que funcionou de 1876 à 1907, localizava-se na antiga rua da estação, hoje atual General Sócrates. (Memorial da Penha de França, acervo digitalizado)

Com a chegada da ferrovia começou a se romper o isolamento do antigo bairro rural da Penha. As atividades econômicas da localidade definitivamente passaram a se voltar para a cidade. Entretanto, essa aproximação não significou o enfraquecimento imediato das características rurais do bairro. Apesar da boa parte da produção econômica passar a ser direcionada à cidade, as atividades de subsistência, o isolamento geográfico as relações sociais e a cultura ainda eram marcadas pelo tradicionalismo construído ao longo dos três séculos anteriores.

\footnotetext{
${ }^{254}$. MORSE, R. M., op. cit., 1970, p. 279.

255. DIÁRIO DO COMÉRCIO. Associação Comercial de São Paulo. Disponível em: ${ }^{256}$. Idem. http://www.dcomercio.com.br/especiais/acsp110anos/ofuturo.htm. Acesso em: 01/05/2006.
} 
Observa-se aqui que a ferrovia representou descontinuidade ao intensificar o processo de urbanização paulistano como um todo, repercutiu na Penha, isto é, intensificou a presença de elementos da cidade na localidade. Consequentemente intensificou o conflito entre a sociedade anterior (rústica) e a que já se formava (moderna e industrial). Não podemos alegar que houve grandes resistências entre o antigo e o novo, no entanto afirmar que as mudanças tenham se processado de maneira imediata seria um erro grosseiro. No entanto a transição entre a sociedade tradicional penhense e a moderna não poderia ter outra mediação senão a vida urbana. Tal mediação proporcionou a mudança das formas e elementos sociais e, no caso da Penha, transcorreu pelo menos no tempo de duas gerações de moradores.

Assim, nessa passagem de rural para urbano, compreendemos que a Penha não podia mais ser considerada bairro rural e nem ainda parte da cidade, mas como uma área de transição, de complementaridade e de negação entre um e outro. Nem barro rural, nem bairro paulistano, daí a condição de subúrbio que estamos atribuindo à Penha nas primeiras décadas do século vinte.

\subsection{A Penha como subúrbio próximo}

Atribuir a condição de subúrbio para a Penha é uma hipótese definida a partir de análise de documentação e referências bibliográficas sobre a localidade e sobre a cidade de São Paulo. Iniciaremos a análise a partir da petição de Ernesto Mariano da Silva Ramos, já citada na nota 249.

Como já analisamos, esta petição faz referência à importância da implementação do Ramal Penha e às vantagens econômicas que poderia representar a circulação de "trens de subúrbio” na localidade. De fato, apenas essa referência não seria suficiente para se definir se a Penha teria ou não sido um subúrbio.

Segundo Langenbuch, tanto para São Paulo quanto para o Rio de Janeiro,

[...] os trens de curto percurso que ligam a estação inicial da respectiva ferrovia às estações mais próximas, em torno das quais surgiram pequenos núcleos de características suburbanas, foram chamados oficialmente de 'trens de subúrbio' ou 'trens suburbanos 'para distingui-los dos trens 'expressos' que iam para mais longe. Isso no Rio marcou a região recortada pelas ferrovias de tal modo que, ainda hoje, ela é rotulada genericamente como subúrbio, embora já no início do século XIX não houvesse mais solução de continuidade em boa parte da área edificada, hoje toda emendada. No falar da população carioca, a designação 'subúrbio' é dada mais precisamente às áreas recortadas pela ferrovia que ficam no município do Rio de Janeiro, chamando-se a parcela territorial urbanizada sita 
em municípios vizinhos, via de regra, pelo nome regional de 'Baixada Fluminense'. ${ }^{257}$

Aroldo de Azevedo, em sua obra de 1945, "Subúrbios Orientais de São Paulo", evoca a noção de subúrbio para designar a Penha. O autor atribui à localidade, na primeira metade do século vinte, certa “individualidade geográfica” que se definia pela suas características físicas, “seu núcleo principal é constituído por uma elevação bem marcada - a colina da Penha que se separa do centro urbano pela baixada do Aricanduva, por sua vez antecedida pela do Tatuapé, e da região da Cantareira, pela vasta baixada do Tietê" ${ }^{258}$ e pela sua história, “afamado centro religioso” que confere ao subúrbio uma “fisionomia particular”. Segundo Azevedo, a Penha da década de 1940 se apresentava como considerável aglomeração humana "no meio dos 'vazios 'que a circundam”. 259

Segundo Azevedo, identificar a Penha como subúrbio paulistano em plena década de 1940 poderia soar estranho para qualquer análise que levasse em conta a expansão da metrópole paulista. A seu ver, a metrópole já havia alcançado a região da Penha, pois a descontinuidade da mancha urbana era contestável, uma vez que o casario apenas se tornava rarefeito quanto se alcançava as regiões do Tatuapé e do vale do Aricanduva, sem a presença de vazios que marcassem nitidamente a separação. ${ }^{260}$ Entretanto, Azevedo alega que tal continuidade não é suficiente para desqualificar o conceito de subúrbio para a Penha do período.

Dentro do conceito de subúrbio estabelecido para análise no momento de sua pesquisa, o autor, além da individualidade geográfica, alega que a região da Penha se representava "nitidamente [com] uma zona de transição entre a zona urbana da Capital e a zona suburbana propriamente dita”261, tornando-se difícil dizer onde, para além da Penha, começavam os subúrbios de São Paulo.

Azevedo conclui que, para o período por ele estudado, a Penha era uma das portas de entrada da cidade de São Paulo e tratava-se, “ao mesmo tempo, de um bairro afastado e um subúrbio próximo da capital paulista."262 No entanto, para Azevedo, se voltássemos vinte e cinco anos atrás, portanto a 1915, o “isolamento da Penha era um fato e ninguém duvidava em considerá-la um subúrbio.,263

257. LANGENBUCH, J. R., op. cit., 2001, p.87.

258. AZEVEDO, Edgard Aroldo de. Subúrbios Orientais de São Paulo. Tese de concurso à cadeira de Geografia do Brasil da Faculdade de Filosofia, Ciências e Letras da Universidade de São Paulo. São Paulo, 1945, p.61-62.

259. Ibidem, p.62.

${ }^{260}$. Idem.

${ }^{261}$. Ibidem, p.63.

${ }^{262}$. Ibidem, p.65.

${ }^{263}$. Ibidem, p.63. 
Ao que tudo indica, em meados dos anos de 1940, para Aroldo de Azevedo, a Penha encontrava-se na transição de subúrbio para bairro paulistano.

Segundo Martins, atualmente pode-se dizer que subúrbio se apresenta como " $o$ lugar em que o passado rural de algum modo sobrevive no urbano" 264 e a noção de subúrbio "foi e tem sido mais a designação de um modo de vida peculiar especificamente referido às regiões de confim entre a cidade e o campo.,"265

Assim, pelo menos no começo do século vinte, a Penha poderia ser considerada um subúrbio. No entanto vamos aprofundar um pouco mais a análise sobre a noção de subúrbio.

Segundo Martins, a primeira vez em que ele se deparou com a noção de subúrbio foi num levantamento oficial sobre a região do atual ABC, feito no século dezoito. Depois o autor afirma que voltou a ter contato com tal noção em um documento do século dezenove, quando os ingleses da São Paulo Railway adotavam a palavra subúrbio “para indicar a região correspondente ao trecho da ferrovia que era cotidianamente tributário da cidade de São Paulo.”266 Martins ainda afirma que a noção de subúrbio surge claramente associada ao desenvolvimento urbano de São Paulo, isto é, à difusão de atividades propriamente urbanas e à ampliação do número de moradores do seu núcleo estável, “em decorrência, a cidade começa a deixar de ser apêndice do campo e o campo começa a se tornar apêndice da cidade."267

Martins observa que, até o século dezenove, a noção de subúrbio apresentava-se como "consciência de uma realidade espacial intermediária entre a cidade e o campo.”268 Neste período da historia da cidade de São Paulo, Martins afirma que

${ }^{264}$. MARTINS, José de Souza. Depoimento. In: Espaço \& Debates, Revista de Estudos Regionais e Urbanos, número 42, Ano XVII, São Paulo, 2001, p.78.

265. Idem.

266. Ibidem, p.75. Segundo o autor, a "noção de subúrbio foi utilizada em relação ao entorno da cidade de São Paulo durante dois século. A primeira referência que encontrei a essa palavra foi num levantamento oficial realizado na segunda metade do século XVIII. Referia-se à atual região do $A B C$, povoada por moradores de algumas fazendas e de alguns bairros rurais a elas vinculados, muito ligados à dinâmica cotidiana da cidade de São Paulo. A palavra ainda era utilizada nos anos sessenta do século XX. Na estação de Paranapiacaba ainda existe uma placa indicativa apontando a plataforma de embarque nos trens de subúrbio. Os ingleses que construíram a São Paulo Railway, no século XIX, adotaram a palavra para indicar a região correspondente ao trecho da ferrovia que era cotidianamente tributário da cidade de São Paulo, entre a estação de São Bernardo (depois, Santo André) e a estação da Lapa. Com o tempo, a própria ferrovia estendeu o conceito de subúrbio para Mauá, na direção de Santos, e para Francisco Morato, na direção de Jundiaí."

267. Idem. Segundo Martins, "é o momento do surgimento e difusão da noção de subúrbio, o que de algum modo coincide com a restauração da Capitania de São Paulo e o estabelecimento de um capitãogeneral residente na cidade. São Paulo tornou-se, assim, capital da então extensa capitania, residência de um representante da Coroa e presença do poder central e monárquico em face do poder municipal e republicano da Câmara."

${ }^{268}$. Ibidem, p.76. 
[...] o subúrbio era predominantemente habitado por escravos e índios administrados, mas sobretudo por caipiras, então denominados bastardos, filhos da mestiçagem de índias e brancos [...] subúrbio é o lugar em que perduram as crenças religiosas da sociedade tradicional. ${ }^{269}$

Segundo Martins, "a noção de subúrbio sublinha o que é propriamente a urbe, a cidade, aquilo que ele não é espacialmente, mas de algum modo é economicamente. Ao mesmo tempo atenua o novo contraste entre a cidade e a roça, o bairro rural, a fazenda."270 Martins ainda afirma que "há um certo encanto estético no subúrbio, uma certa nostalgia de algo que se está perdendo, a suave diferenciação entre estar na vila e viver na roça."271 Tais concepções (sociais, estéticos e também espaciais) são reflexos da mentalidade do modo de vida da cidade sobre o modo de vida no campo ou talvez da ordem distante (a do mercado, do Estado e seus processos, etc.) determinando formas e impondo sua divisão sócio-espacial ao meio rural.

Segundo Langenbuch, subúrbio "refere-se à parte da cidade localizada em contato com o campo, em que a implantação urbana ainda é incipiente [...] das bordas incompletamente urbanizadas, mesmo em grandes cidades." ${ }^{272}$ Nesses termos, as considerações de Langenbuch sobre o subúrbio, enquanto realidade espacial intermediária entre a cidade e o campo, se aproxima daquelas desenvolvidas por Martins e Azevedo.

Morse também oferece argumentos que reforçam a hipótese da condição de subúrbio para a Penha das primeiras décadas do século vinte. A seu ver, os arredores da cidade de São Paulo do período acima poderiam ser classificados em duas zonas segundo a função agrícola que desempenhavam: para da prática de cultura de subsistência e para a prática da agricultura comercial com extensão limitada ao abastecimento da cidade. O autor considera essa prática agrícola próxima à cidade de “agricultura suburbana”. ${ }^{273}$

Segundo André Martin, ao analisar o Brás como espaço suburbano no final do século dezenove:

[...] o Brás embora não tão distante, ma devido ao difícil acesso, tinha suas chácaras preferencialmente ligadas às atividades rurais, mesmo que muitas delas apresentassem todo o conforto, quer fossem residenciais ou de recreio. Mesmo quando já estavam ocorrendo subdivisões em algumas chácaras, o uso preferencial das mesmas seguia sendo ligado a terra. Isto porém não é o suficiente para situarmos o Brás como um 'bairro rural', pois suas funções adequam-se melhor ao rótulo de 'subúrbio’. Além dos proprietários das chácaras, habitavam o nascente bairro também escravos que trabalhavam nas pequenas lavouras, alguns caseiros que cuidavam das casas de campo e até condutores de 'tílburis', uma profissão inegavelmente urbana. Apesar disso o hábito de deixar a casa de campo

\footnotetext{
269 . Ibidem, p.78.

${ }^{270}$. Ibidem, p.76.

${ }^{271}$. Idem.

272. LANGENBUCH, Juergen Richard. Depoimento. In: Espaço \& Debates, Revista de Estudos Regionais e Urbanos, número 42, Ano XVII, São Paulo, 2001, p.87.

273. MORSE, R. M., op. cit., 1970, p. 359.
} 
vazia quase o ano todo ainda se mantinha, pois muitos fazendeiros para lá se dirigiam apenas algumas vezes por ano, principalmente nas festas juninas e no Natal [...] Em suma, notamos que havia uma ligação funcional muito estreita entre o Brás e o centro da cidade, suficiente para não colocá-lo como um 'bairro rural'. ${ }^{274}$

Mais adiante o autor complementa que:

[...] o Brás representou a primeira periferia urbana de São Paulo, introduzindo novas relações com o núcleo central, onde as chácaras funcionalmente suburbanas forneceram o fundamento econômico de sua ocupação. Nesse sentido podemos concluir em síntese, que o Brás desde sua origem em meados do século XVIII até a segunda metade do século XIX, viveu espacialmente a condição de uma transição entre um 'subúrbio' e um 'bairro rural' sem que nele se registrasse uma urbanização mais efetiva. Esta, com efeito, só viria mais tarde, mas sob o impulso já de noivas forças, aliás, poderosas, que transformariam profundamente a estrutura social de todo o país: a industrialização. É com ela que o Brás se desenvolveria e se tornaria um segmento areolar urbano plenamente individualizado e personalizado. Com a indústria, o Brás se tornaria um dos mais populosos e conhecidos bairros de São Paulo: o bairro operário do Brás. ${ }^{275}$

Assim, podemos observar que é a ligação com a cidade que determina a condição de subúrbio para o Brás e conforme essa ligação aumentava a condição vai se extirpando. Como o Brás do século dezenove, o mesmo vai se processar na Penha do final do século dezenove e nas primeiras décadas do século vinte. Como um efeito dominó, após o Brás, a Penha, que a partir da chegada da ferrovia e da industrialização passará por profundas modificações em sua estrutura social até que a condição de subúrbio também venha a se exaurir. Continuemos nossa análise.

Não há dúvidas que na Penha se desenvolvia a “agricultura suburbana”. Como vimos, a economia penhense da virada do século se caracterizava pela presença de atividades agropecuárias que atendiam as necessidades da cidade. As várias chácaras produtoras de hortifrutigranjeiros abasteciam a cidade utilizando o trem e o bonde elétrico, que chegou à Penha em $1914 .{ }^{276}$ Essa função abastecedora já existia antes, porém era menos expressiva. Ocorria a partir da utilização do transporte animal (os produtos era transportados no lombo de animais ou em tílburis pela precária Estrada da Penha, que na várzea do Tatuapé sofria com as cheias do Tietê, até o Marco de Meia Légua, local que desde 1877 era parada dos bondes de tração animal, onde eram baldeados e completavam a viagem até o mercado consumidor) ${ }^{277}$ e fluvial (pelo rio Tietê).

Assim, vemos a Penha das três primeiras décadas como um subúrbio, onde a função principal estava baseada na prática da agricultura suburbana, principal fator de

\footnotetext{
274. MARTIN, A. R., op. cit., 1984, p.51.

275 . Ibidem, p.54-55.

${ }^{276}$. LANGENBUCH, J. R., op. cit., 1971, p.84.

277 . MORSE, R. M., op. cit., 1970, p.21.
} 
ligação com a cidade. A religiosidade também era importante, e ainda se apresentava como o principal fator de aproximação com a cidade.

À medida que a cidade de São Paulo crescia, a produção dos sitiantes deixava de ser direcionada para as necessidades dos mercados locais. Assim, interessados no abastecimento da cidade, tanto a produção quanto as técnicas utilizadas passavam por mudanças quantitativas e qualitativas As relações trabalhistas também sofriam reformulações e a mão-de-obra familiar, quando não convivia com a assalariada, era substituída definitivamente por esta. As conseqüências dessas transformações eram bastante rápidas e os sitiantes que não se adaptavam acabavam vendendo suas terras e, ou migravam para áreas mais distantes, ou permaneciam no local como assalariados locais, ou passavam a prestar serviços na cidade. ${ }^{278}$

Segundo Queiroz, os sitiantes que migravam para essas áreas mais distantes acabavam, com o passar do tempo, também tornando-as produtoras voltadas para o abastecimento da cidade. Assim, mais áreas rurais se transformavam em subúrbio. ${ }^{279}$

Santos, ao estudar os subúrbios do município do Rio de Janeiro, também considerou uma mescla de rural e urbano e também observou que subúrbio está efetivamente relacionado ao aglomerado que possuía sua vida econômico-social estabelecida a partir de uma relação mais próxima com a cidade, pela função de abastecer, tanto no fornecimento de gêneros primários quanto no fornecimento de mão-de-obra, principalmente para as indústrias que começavam a se estabelecer. ${ }^{280}$

Nas duas primeiras décadas do século vinte, apesar de todas as mudanças sócioeconômicas que ocorriam na cidade, pouca coisa tinha se alterado na malha urbana do subúrbio penhense. O ritmo bucólico era marcado pela presença da Igreja e a solidariedade vicinal ainda era uma prática. O isolamento do aglomerado garantia a manutenção da antiga identidade desenvolvida a partir das práticas lúdico-religiosas tradicionais. Parece déjà-vu, mas é necessário reafirmar aqui, a configuração da paisagem ainda continuava a mesma: uma igreja, sua praça e uma porção pequena de ruas rodeadas por chácaras. Conforme podemos ver no Mapa 4.

Podemos propor que a configuração da Penha enquanto subúrbio se processou em duas etapas, "subúrbio de cunho rural”, depois, "subúrbio de cunho urbano."281 Segundo Langenbuch, “os subúrbios de cunho urbano”

278 . QUEIROZ, M. I. O., op. cit. 1978, p.53-54.

279 . Idem.

${ }^{280}$. SANTOS, J. J. M. dos, op. cit., 1996, p.227-228.

281 . LANGENBUCH, J. R., op. cit., 1971, p.260-261. 
[...] representam prolongamentos de formas de uso do solo urbano - fora do bloco compacto ou de seus limites político-administrativos. Em contrapartida, os 'subúrbios de cunho rural' encerram formas de 'uso do solo', estabelecimentos, paisagens, indiscutivelmente rurais ou pelo menos não urbanas [...] Seu caráter de 'subúrbio' lhes é conferido por concentrarem aspectos habitualmente apresentados pelas porções de campo vizinhas às grandes cidades, e pelas intensas relações funcionais que mantém diretamente com a metrópole. ${ }^{282}$

Enquanto predominaram as inúmeras chácaras na região da Penha, acreditamos que a definição de subúrbio mais correta a ser utilizada poderia ser a de "subúrbio de cunho rural”. Após 1920, quando essas chácaras passaram a ser alvo da especulação imobiliária e a mancha urbana da Penha se ampliou com o aparecimento de alguns loteamentos, a classificação mais correta poderia ser "subúrbio de cunho urbano." Podemos observar essa evolução comparando o Mapa 4, página seguinte, com o Mapa 3.

Podemos observar também, no Mapa 4, que uma nova linha férrea se estabelece na região da Penha. Em 07 de fevereiro de 1926, foi inaugurada a variante Poá da Central do Brasil.

Segundo Langenbuch,

[...] a 'variante de Poá' da estrada de ferro 'Central do Brasil' trata-se de linha alternativa, que dobra a linha São Paulo-Rio, da mencionada ferrovia, perlongando esquematicamente o contato entre a várzea do Tietê e os terraços e colinas adjacentes. A partir de então, a linha antiga, oficialmente denominada 'ramal de São Paulo', passa a ser localmente conhecida por 'linha tronco', por antonímia a novel 'variante'. Esta, como se verá, imediatamente, passa a desempenhar importante papel na expansão suburbana de São Paulo. ${ }^{283}$

Sua bifurcação ocorreu na direção nordeste, partindo do trecho localizado entre a estação Quinta Parada e a estação Guaiaúna, seguindo a várzea do rio Tietê até a cidade de Mogi das Cruzes onde voltava a se juntar à Central do Brasil. ${ }^{284}$

Da mesma forma que ocorre ao longo da Central do Brasil na porção sul do bairro, nas laterais da ferrovia foi instalada uma via pública, Avenida Assis Ribeiro de um lado e o do outro, várias indústrias, com destaque para as indústrias Matarazzo, em Ermelino Matarazzo. ${ }^{285}$

\footnotetext{
${ }^{282}$. Idem.

${ }^{283}$. Ibidem, p.140.

${ }^{284}$. De imediato não foram instaladas estações ferroviárias próximas ao aglomerado. Junto ao ramal, em 07 de fevereiro de 1926, surgiram as estações Engenheiro Goulart, aproximadamente a quatro quilômetros da porção central da Penha, Comendador Ermelino, São Miguel Paulista, Itaim, Engenheiro Manuel Feio, Itaquaquecetuba e Aracaré. A estação ferroviária de Trindade, mais próxima da Penha, só foi inaugurada em 01 de Janeiro de 1934.

${ }^{285}$. PETRONE, P., op. cit., p.139. É importante salientar que para este autor, nas três primeiras décadas do século XX, o capital industrial já havia definido as principais áreas para estabelecimento de suas fábricas. A seu ver, "não resta dúvida que as principais áreas industriais acompanham as vias-férreas: Brás, Belenzinho, Tatuapé, Comendador Ermelino e São Miguel Paulista, ao longo da 'Central do Brasil'; ainda o Brás, Pari, Mooca, Ipiranga, São Caetano do Sul e Santo André, acompanhando a
} 


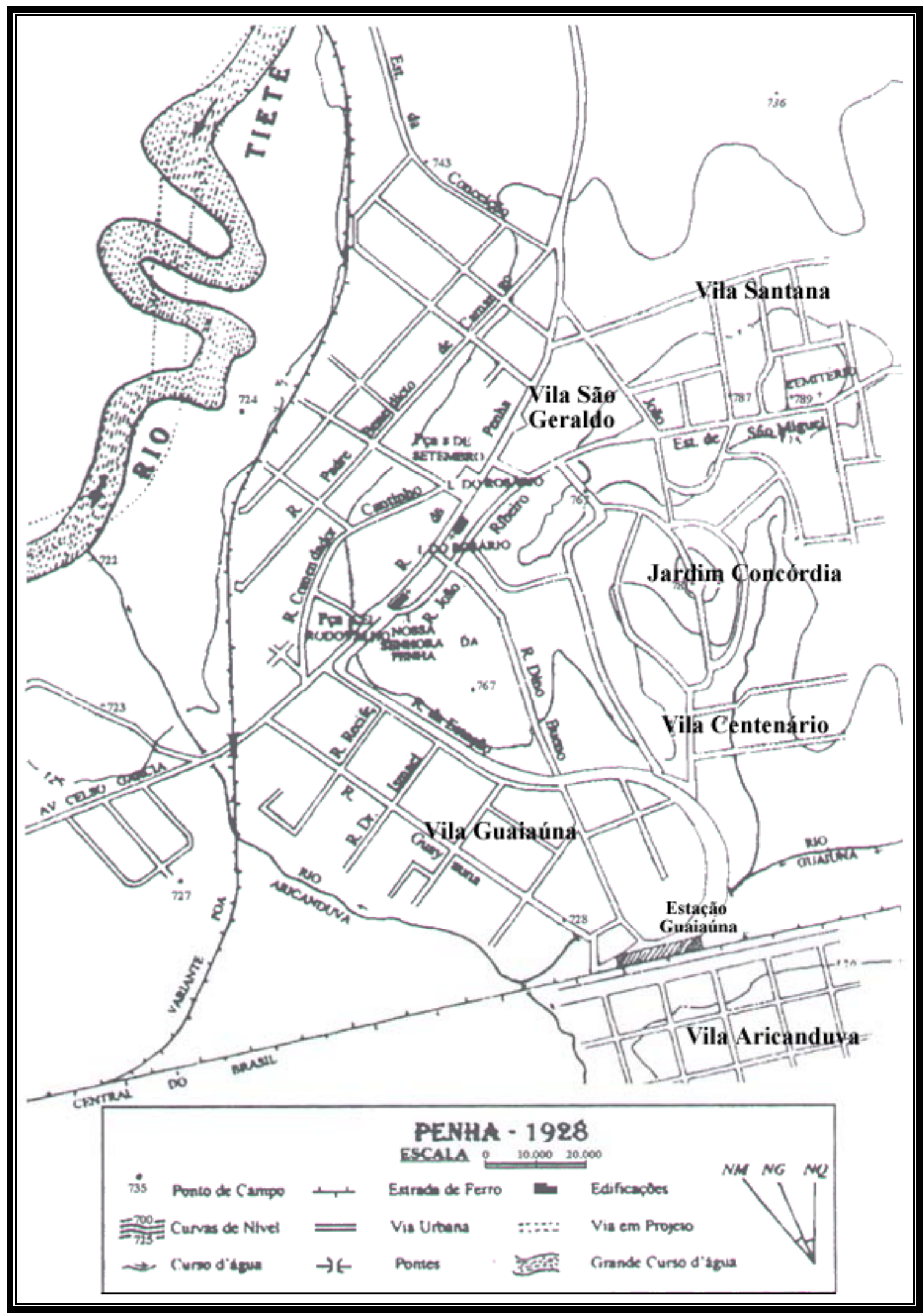

'Santos-Jundiaí'; Barra Funda, Água Branca, Lapa e Osasco, servidas tanto por esta via-férrea, como pela 'Sorocabana'[...]”' 
Mapa 4 - Fonte: Planta da cidade de São Paulo, Repartição de Águas Esgotos, org. José Emiliano Schalc, escala 1:20.000, 1897. As curvas de nível foram adaptadas da Carta da Penha de França (indicações diversas), índice de Nomenclatura: SF-23-Y-C-V1-2-NE-B, São Paulo-SP, escala 1:10.000, 1981, org.

EMPLASA (Organização e simplificação: Edson Penha de Jesus)

O papel da ferrovia neste processo é muito importante, pois ela colaborou como real agente da ocupação desigual no tempo e no espaço do território penhense. Afinal, era comum às vias férreas e suas estações, assim que se regularizava o tráfego de passageiros, atraírem para as áreas por onde passavam o interesse daqueles que migravam na procura de novas áreas para a construção de suas moradas, substituindo lentamente o uso e o modo de vida rural pelo uso e o modo de vida urbano.

No compasso do aumento da atividade industrial paulistana e da sua proporcional crescente necessidade de mão-de-obra, os subúrbios passaram a ser alvo do interesse imobiliário e loteamentos passaram a pipocar por todas as partes da cidade. A implantação de um loteamento beneficiava os locais onde se estabeleciam, pois proporcionava o desenvolvimento mínimo de infra-estrutura (serviços de transporte, energia elétrica, abastecimento de água e saneamento e também favorecia a expansão de setores financeiros e comerciais). ${ }^{286}$

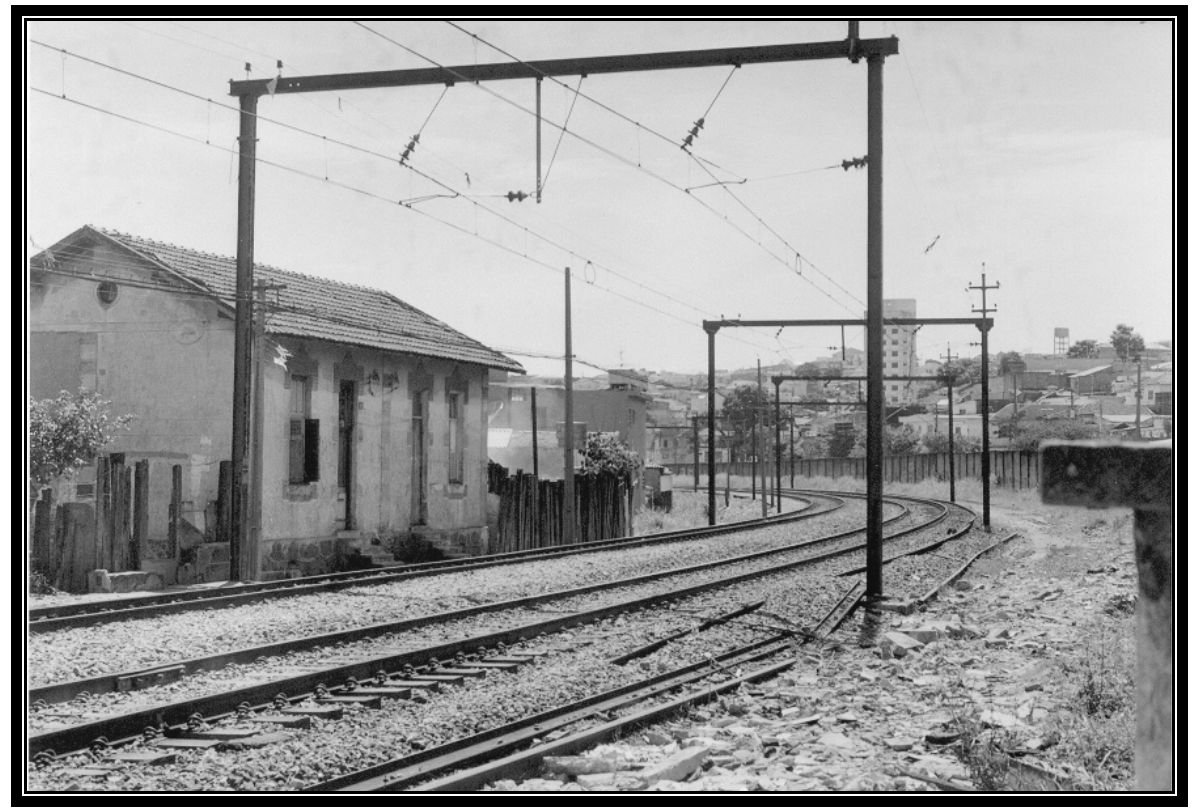

Variante Poá (Foto: Edson Penha de Jesus-2002)

Os impostos altos cobrados na porção central de São Paulo e suas adjacências mais próximas também contribuíram para a expulsão dos trabalhadores e suas famílias em

${ }^{286}$. SANTOS, J. J. M. dos, op. cit., 1996, p.224. 
direção a loteamentos populares localizados nos subúrbios. ${ }^{287}$ Enquanto uma parte dessa famílias passou a se amontoar nos cortiços, outra vai se deslocar para áreas como a Penha. Assim, a região penhense recebeu uma grande massa de trabalhadores e passou definitivamente a se constituir como área residencial.

Segundo Santos, ao analisar fenômeno parecido no Estado do Rio de Janeiro,

[...] o processo de formação do subúrbio a partir de tais atribuições e da área correspondente a princípio às freguesias, dentre outros fatores essenciais à execução, como papel dos trens, das diferentes formas de especulação imobiliária, das medidas legais regulando a ocupação urbana que se dava na região, por exemplo, decorreu principalmente de um posicionamento definido pelo estado nesse sentido. Ou seja, resultou antes de tudo da intenção do poder público [...] de direcionar para o subúrbio e não para qualquer parte do município, as camadas pobres e trabalhadores que se comprimiam no centro da cidade, fazendo do subúrbio [...] a principal área para a residência desses habitantes. ${ }^{288}$

A década de 1940 deve ter sido a do apogeu da vida de bairro na Penha.

\subsection{A valorização do espaço e o avanço da urbanização.}

Segundo Martin, a urbanização brasileira seguiu ritmo lento enquanto se mantinha o "padrão colonial”"289, caracterizado pela combinação entre a estrutura escravista da sociedade e estrutura exportadora da economia. Mesmo tendo começado a estruturação do mercado interno, no sentido de "torná-lo auto-sustentado e relativamente autônomo face

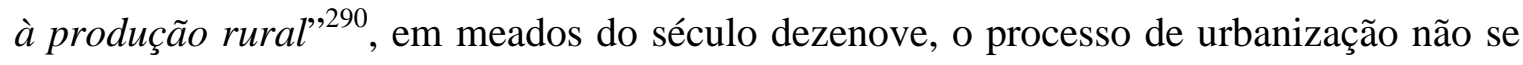
efetuava.

Segundo Martin tal momento apenas chegou "no bojo do intrincado processo no qual o trabalho servil foi paulatinamente sendo substituído pelo 'trabalho livre' que abriu entre nós as possibilidades da industrialização"291 e consequentemente da urbanização.

A cidade de São Paulo somente começou a crescer de forma acelerada após a virada do século quando, impulsionada pela da cultura do café e pela abolição da

${ }^{287}$. LANGENBUCH, J. R., op. cit., 1971, p.137. Afirma Langenbuch para o mesmo período: "sem dúvida a mencionada majoração fiscal se acha ligada à valorização fundiária, provocada de uma parte pela pressão exercida pela cidade sobre sua periferia, e de outra parte grandemente ampliada pela especulação imobiliária, graças a qual havia sempre um gigantesco mercado comprador, formado por pessoas que adquiriam terrenos somente pela assegurada valorização que lhes permitiria auferir grandes lucros na revenda."

288 . SANTOS, J. J. M. dos, op. cit., 1996, p.252.

289 . MARTIN, A. R., op. cit., 1984, p.56.

${ }^{290}$. Idem.

${ }^{291}$. Idem. 
escravatura, grande contingente de imigrantes, mão-de-obra livre, se estabeleceu na cidade. $^{292}$

Segundo Sampaio:

[...] o imigrante é considerado o grande elemento dinamizador da sociedade do Brasil republicano. Junto com imigração subvencionada pelo Estado, com o objetivo de fornecer mão-de-obra para a agricultura, chegam também imigrantes avulsos, que procuram as cidades, especialmente São Paulo. Datam desta época, as duas últimas décadas do século XIX, o surgimento das primeiras fábricas na cidade, ao mesmo tempo que se tornou sentida e visível a inadequação do núcleo colonial que já não mais atendia às novas necessidades urbanas da cidade que tinha aumentado quase quatro vezes sua população no curto espaço de 10 anos, passando de 64.934 habitantes em 1890 a 239.820 em $1900 .{ }^{293}$

Como podemos perceber a cidade não estava preparada para receber essa massa de novos moradores. A necessidade de alojar tantos imigrantes exigia alguma providência do Estado, pois os mesmos começavam a se amontoar nos insalubres cortiços e demais habitações operárias próximos ao centro de São Paulo.

Já em 1893, sob ameaças de epidemias e outros problemas sanitários, a Câmara Municipal de São Paulo formou uma Comissão de exame e inspeção sanitária destas moradias no distrito de Santa Efigênia e de imediato se averiguou a extensão do problema e a necessidade de soluções imediatas. Assim a comissão propôs como solução a possibilidade de assentar essa população em áreas mais distantes, nas regiões suburbanas, principalmente onde as ferrovias faziam suas estações. ${ }^{294}$

Segundo Sampaio, o relatório da Comissão propôs até as áreas onde as futuras vilas operárias deveriam ser construídas: estação Pirituba, várzeas do Tamanduateí, Ipiranga, estações de São Caetano e de São Bernardo, região da Penha, Aricanduva e Tatuapé, estação de São Miguel, ao longo da linha férrea de Santo Amaro e Pinheiros, entre outros. $^{295}$

A manutenção das classes trabalhadoras nas áreas centrais e suas adjacências não interessava às classes dominantes e o deslocamento da mesma em direção aos subúrbios se apresentava como necessidade.

292. SAMPAIO, Maria Ruth Amaral de. O papel da iniciativa privada na formação da periferia paulistana. In: Espaço \& Debate: A cidade Brasileira, século XX, n³7, São Paulo: NERU, 1994, p.19.

293 . Idem. Apud ARAUJO FILHO, J.R. de. A população paulistana. In: AZEVEDO, Aroldo de, org. A cidade de São Paulo. Estudos de Geografia urbana. São Paulo: Nacional, vol.2, 1958.

294. Ibidem, p.19-20. Segundo a autora, a comissão indicou que essa população poderia ser alojada em subúrbios que se localizassem entre 10 e 15 quilômetros da capital. Sampaio ainda transcreve parte do relatório desta Comissão onde há uma sugestão que vale repetir aqui: "as vias férreas que irradiam desta capital duplicassem suas linhas, ou, pelo menos, multiplicassem os desvios até a distância de 15 $\mathrm{km}$, ainda que para isso concorresse o Estado com um auxílio qualquer, as vilas operárias surgiriam pouco a pouco ao longo dessas linhas, talvez sem maior auxílio dos cofres públicos.”

${ }^{295}$. Ibidem, p.20. 
Podemos observar que o Estado incentivava nos subúrbios, até então áreas de produção agrícola para abastecimento, uma nova função: moradia para operários. Neste processo, o Estado não se apresentou como gerenciador direto. Outra proposta vinda da tal Comissão foi a sugestão de que a participação da iniciativa privada em todo o processo de ocupação dessas áreas (por meio de loteamentos e construção de vilas e habitações operárias) fosse reforçada.

O Estado enquanto intermediário, tinha apenas a função de facilitar o processo, ou seja, garantir a jurisprudência necessária, facilitar o desenvolvimento de infra-estruturas como as de transportes, desapropriar terrenos, garantir os lucros, entre muitos outros. ${ }^{296}$ Veremos que a Penha não entra de imediato neste processo.

Faz-se necessário um aparte aqui, para relembrarmos que tal possibilidade só se efetuou graças à expansão da lavoura comercial do café que criará as condições iniciais para o desenvolvimento da industrialização. Objetivamente, segundo Martin, tais “précondições” responsáveis pelo advento da industrialização brasileira foram:

[...] pelo lado das forças produtivas, a instalação de toda uma rede ferroviária que revolucionou as condições gerais de produção; pelo lado da força de trabalho, uma enorme leva de imigrantes europeus transformaria profundamente a estrutura da população; pelo lado das relações de produção teríamos o 'colonato' como singular forma responsável pela diluição do escravismo e a transição para o assalariamento. ${ }^{297}$

A cafeicultura, totalmente voltada para o mercado externo, experimentou enorme crescimento a partir de 1870. A acumulação capitalista aumentou consideravelmente e na mesma proporção que o mercado externo, o mercado interno começou a se desenvolver. A indústria se fortaleceu neste viés da economia nacional.

Segundo Martin:

[...] de um lado a indústria nascente, fornecendo máquinas de beneficiamento de café, sacaria, oficinas de reparos de trens, fazia aumentar a rentabilidade das lavouras; de outro a cafeicultura, com rendas auferidas pela exportação. Com isso, o 'complexo cafeeiro' acabaria tornando-se o mercado para a indústria, uma vez que o consumo dos bens não duráveis produzidos pela indústria têxtil e alimentícia recaia principalmente sobre os 'colonos'. ${ }^{298}$

Martin esclarece que a indústria brasileira ainda vai passar muito tempo subordinada ao capital cafeicultor. Esclarece, também, que a figura do imigrante apresentou-se fundamental, tanto como mão-de-obra, quanto como consumidor, para o processo de industrialização que o Brasil desenvolveria nos anos posteriores. ${ }^{299}$

\footnotetext{
296 . Idem.

297 . MARTIN, A. R., op. cit., 1984, p.56-57.

298 . Ibidem, p.63-64.

299 . Ibidem, p.64-66.
} 
Com o encilhamento, transtornos especulativos que afetaram a Bolsa de Valores em 1889-1890 (durante Governo Provisório de Deodoro da Fonseca - 1889-1891 - e seu ministro da fazenda Rui Barbosa), os investidores do café passaram a diversificar suas aplicações e procurar novas possibilidades de lucros. Deste processo saíram fortalecidos a indústria e o mercado de imóveis.

Segundo Sampaio, "na época do encilhamento, entre 1889 e 1891, a dinamização da economia teve como conseqüência intensa atividade nos ramos imobiliários e de construção civil." ${ }^{300}$

Sobre o dinamismo da economia urbana na virada do século dezenove para o vinte, Brito reforça essa análise destacando três fatores importantes: a) uma disponibilidade de capitais que vinha se configurando desde a proibição do trafico negreiro (1850), quando houve a liberação de capitais imobilizados na economia cafeeira e que estes foram direcionados para novos investimentos; b) o crescimento demográfico e econômico da capital, decorrente principalmente de imigrantes e proprietários rurais que fixaram suas residências na cidade, ambos aparecem como propulsores da economia urbana, tanto como empreendedores como consumidores da mesma; c) a busca de empreendimentos mais seguros para investimento, a instabilidade econômica que caracterizou os anos antes da abolição da escravatura e da proclamação da República tornaram os investidores mais cautelosos. ${ }^{301}$

Assim, aplicar capital em imóveis, principalmente para locação era o negócio mais garantido e isento de riscos que existia, tanto para os fazendeiros de café, quanto para os que se aventuravam na indústria. Segundo Sampaio:

A atividade agrícola do fazendeiro do café, apesar de bastante lucrativa, era irregular e estava sujeita não só às oscilações do preço do produto no mercado mundial, às variações das taxas de câmbio, mas também às transformações metereológicas. A instabilidade os convidava a aplicar seus lucros em atividades diversas. Os industriais, por sua vez, também sofriam os percalços da política cambial, monetária e fiscal, além da concorrência dos produtos estrangeiros. A idéia de diversificar as aplicações de capital, aliada à lucratividade do setor imobiliário, levou os mais diversos empreendedores, inclusive industriais, a

\footnotetext{
${ }^{300}$. SAMPAIO, M. R. A. de, op. cit., 1994, p.20. Segundo a autora, "nesses dois anos, 14 companhias dedicadas à construção civil iniciaram suas atividades na cidade, além da constituição de sete imobiliárias e quatro empreendimentos ligados a produção de material de construção, como cerâmica, telhas e tijolos. A maioria desses empresários estava ligada a dois ou mais empreendimentos, envolvendo principalmente especulação com terrenos além de comércio de materiais de construção, serrarias, olarias. Apareciam nos registros como capitalistas, comerciantes, negociantes e industriais, sendo rara a menção fazendeiro; a análise dos nomes envolvidos esclareceu que muitos desempenhavam todas essas atividades ao mesmo tempo, acrescidas muitas vezes de cargos públicos, como deputado, senador e até presidente da província."

301 . BRITO, Mônica Silveira. A participação da iniciativa privada na produção do espaço urbano: São Paulo. 1890-1911. Dissertação de Mestrado. FFLCH-USP. São Paulo, 2000, p.116
} 
aplicar seus excedentes em atividades imobiliárias de casa de aluguel, aplicações estas que além de vantajosas eram seguras. ${ }^{302}$

Não aprofundaremos esse estudo aqui, mas o usaremos como referência para analisar os fenômenos da valorização do espaço e da urbanização na Penha.

Os trilhos da ferrovia se apresentaram como guia para o mercado de imóveis na cidade. Os subúrbios, até então locais de reprodução da vida e da economia rural, passaram a se apresentar como áreas propícias à especulação capitalista.

A Penha poderia de imediato ter se tornado área de atração destes especuladores, no entanto não o foi. Temos por hipótese que alguns fatores a excluíram deste processo pelo menos nas duas primeiras décadas do século vinte. Seriam esses fatores: a distância das áreas onde as indústrias se instalavam; a falta de infra-estrutura urbana adequada; os moradores que ainda tinham na agricultura sua fonte de renda; ter a ferrovia como único meio eficaz de transporte para a cidade, já que a Estrada da Penha sofria demais com inundações e; até os alagados dos rios Tietê, Tatuapé e Aricanduva impediam que a região entrasse de imediato na ciranda da especulação.

As indústrias se instalavam próximas às estações ferroviárias, no entanto na porção leste da cidade não chegaram a adquirir grande densidade, acabaram apenas se concentrando em localidades como o Brás, a Mooca, o Pari e o Ipiranga. Foi ao longo da Santos - Jundiaí que se devolveu a principal área industrial da cidade. ${ }^{303}$

Para se desenvolver, o mercado imobiliário na Penha teria que esperar que começassem o esgotamento das áreas mais próximas da cidade. Uma coisa era certa, o valor da terra já não era mais o mesmo de décadas anteriores.

O valor da terra até então fixado pela capacidade de produção e pela possibilidade de distribuição do que se produzia teve seu lastro vinculado a outra condição: o mercado de terras. Em tal condição, tanto os proprietários rurais quanto os empreendedores do mercado imobiliário visualizaram possibilidades de lucros com o loteamento das propriedades. No entanto, na Penha esse loteamento obedeceria a outros ritmos.

Tanto que mesmo tendo como possuidor de terras na região o Cel. Antonio Prost Rodovalho, que no começo do século vinte era considerado um dos principais empreendedores imobiliários da época, não apresentou nenhum loteamento até os anos vinte.

Faz-se necessário reforçar a importância do Cel. Rodovalho como empreendedor neste momento da dissertação.

${ }^{302}$. SAMPAIO, M. R. A. de, op. cit., 1994, p.20.

${ }^{303}$. Ibidem, p.21. 
O começo do século vinte deixaria muito mais evidente a estratégia de investidores como o Cel. Rodovalho para a Penha. Tal estratégia, que era a praxe de todos que estavam envolvidos no processo de especulação da terra na cidade de São Paulo, tinha como ponto de partida o loteamento e seu arruamento.

Os primeiros loteamentos, entre o final do século dezenove e as primeiras décadas do século vinte, seguiam certa lógica: o empreendedor, umbilicalmente ligado a políticos da cidade (às vezes, como no caso Rodovalho, ocupando ele próprio cargo na Câmara de São Paulo) solicitava algum tipo de infra-estrutura para o local. Poderia ser uma linha férrea, uma linha de bonde, uma estrada ou qualquer outro benefício e uma vez estabelecida tal infra-estrutura, o terreno e toda área por onde se implementava a tal infraestrutura se transformava em área passível de se lotear. Uma vez começado o loteamento, novas infra-estruturas se estabeleciam. E assim ia-se agregando mais valor aos terrenos.

No caso da Penha, temos o já citado ramal ferroviário e a chegada do bonde, onde o contrato municipal se encontra assinado por Antonio Proost Rodovalho. Voltaremos a essa questão mais adiante.

O estabelecimento do fenômeno chamado loteamentos acabou se estruturando e passou a envolver bem mais que proprietários interessados em se desfazer de suas terras para ter lucro certo.

Brito, em seus estudos sobre a produção do espaço paulistano do começo do século vinte, evidenciou a figura do empreendedor no processo. Em sua pesquisa afirma Brito que

[...] os dados coletados revelaram que, se em alguns loteamentos foram fruto da iniciativa de proprietários que, valendo-se da oportunidade de possuir terras em áreas propícias à expansão urbana, recém-dotadas de infra-estrutura, aproveitaram tal valorização, rasgando ruas e vendendo em lotes suas propriedades, sem que, para isso, tivessem que realizar qualquer investimento ou valer-se de táticas empresariais específicas, por outro lado, uma grande parte das iniciativas esteve nas mãos de empreendedores, que assim podem ser chamados porque exerceram um papel bem mais complexo, assumindo uma postura ativa mediante o processo de expansão e dotação material urbanas. ${ }^{304}$

Assim, a concepção de que o crescimento da mancha urbana paulistana no primeiro quartel do século vinte se fazia de modo desarticulado não se confirma, pois o mesmo seguia a lógica do mercado.

${ }^{304}$. BRITO, M. S., op. cit., 2000, p.191. Segundo Brito, as chácaras paulistanas do inicio do século vinte tornaram-se de grande valia para aqueles capitalistas que costumavam diversificar seus investimentos na cidade. Esses investidores vinham dos mais variados seguimentos. Brito os classifica em três grandes grupos: "loteadores proprietários de empresas de materiais para construção"; "loteadores proprietários de empresas imobiliárias e construtoras" e; "pequenos comerciantes que aliavam os mais variados ramos comerciais à produtiva atividade de loteador". Sendo que entre esses últimos estavam os antigos chacareiros e outros que compravam as chácaras para lotear ou revender. (p.5) 
Como já abordamos, a região da Penha, apesar da ferrovia, não se apresentou de imediato para a instalação de loteamentos. Mas não dá para não conferir à região a idéia de ser reserva para o mercado imobiliário. Se levarmos em consideração a lógica do mercado imobiliário, podemos defender aqui que a região da Penha era uma daquelas áreas que deveriam ser negociadas por último: afinal, não se tratava de um local tão atrasado e já apresentava boa parte do equipamento urbano necessário.

A Penha, pelas características naturais favoráveis e pelo seu status religioso, era considerado um lugar interessante para estabelecer moradia. A escolha da localidade para a mansão dos Rodovalho e de outras boas famílias na região atestavam essa condição.

Outra hipótese poderia ser a de que as forças empreendedoras ainda não se haviam estruturado na localidade. Mas seria também equivocado pensar que apenas essa premissa explicaria o fenômeno, pois na localidade morava o Cel. Rodovalho e esse era bem experiente no ramo do comércio de terras. Aliás, essas forças necessariamente eram desprendidas de interesses locais (embora também tivessem interesses na localidade).

Seria o desinteresse econômico dos chacareiros da região em disponibilizar suas terras (lavouras e pecuárias) para o estabelecimento de loteamentos? Afinal, elas garantiam sua subsistência. A proximidade com a cidade e a facilidade de transporte do que produziam garantiam-lhes a comercialização de seus produtos. Assim, essa hipótese também não seria suficiente para explicar; seria inocente creditar somente o valor de uso a essas propriedades.

A resposta está no entendimento do desenvolvimento econômico dos bairros industriais mais próximos. Quando pensamos que a distância de trem entre a Penha e os bairros do Brás, Pari, Belenzinho, Mooca e ao centro da cidade não era tão grande assim, a relativa demora na abertura de loteamentos na Penha se esclarece. O desenvolvimento industrial destas localidades e mesmo da cidade apresenta-se como o termômetro que explica a valorização dos terrenos na Penha. Uma vez que essas áreas se adensaram e as ofertas de lotes próximos às mesmas declinaram os investidores se voltaram para o Tatuapé e depois para a Penha. Aí os chacareiros passaram a oferecer suas terras para lateamentos.

Voltemos ao importante papel da industrialização para o entendimento do desenvolvimento urbano do espaço penhense a partir de 1900. Como vimos a industrialização paulistana passa a se intensificar após a crise café de $1885 .{ }^{305}$ Os anos

${ }^{305}$. MORSE, R. M., op. cit., 1970, p.232. Segundo o autor, “foi por volta de 1885, devido em grande parte a uma queda brusca nos preços mundiais de café, que os comissários urbanos começaram a apertar as 
que se seguiram, como fruto da nova mentalidade burguesa da virada do século, revelaram que o fluxo de capitais começou a abandonar o campo e se direcionar para as atividades urbanas. Nas cidades, esses novos investidores aproveitaram a infra-estrutura que o café utilizava (ferrovias, bancos, portos, eletricidade, outros), a abundante mão-deobra estrangeira e as necessidades de novas aplicações financeiras para aqueles que ainda possuíam capitais e lançaram-se ao investimento em imóveis e ao desenvolvimento das atividades industriais. Assim, o mercado imobiliário e a indústria passaram a se fortalecer e apresentar importância cada vez maior na valorização e organização dos espaços urbanos. $^{306}$

Assim, o processo de industrialização, junto aos interesses do mercado de terras e ações do Estado, incrementou a mercantilização da terra urbana e na mesma proporção, em lugares como a Penha, novos usos e valores passaram a se fortalecer e, assim, o espaço urbano se concretizou.

Industrialização e urbanização, como um único processo, acabaram incorporando grande massa de trabalhadores vindos de todos os lugares do Brasil e do mundo.

No contexto da valorização do espaço penhense, podemos afirmar que a industrialização não se reduziu apenas em direcionar uma massa de operários que passaram a residir aí. Como aconteceu em toda a cidade, a industrialização trouxe consigo também outros equipamentos que viessem a ser interessantes para a mesma (comércio, prestadoras de serviços, outros).

Não podemos esquecer que a atividade industrial proporciona empregos diretos e indiretos e a simples presença de uma fábrica altera toda estrutura social e econômica do que se encontra nas suas cercanias. Segundo Singer, "isto faz com que a demanda total de terrenos seja um múltiplo da demanda direta da indústria e consequentemente a pressão

suas tenazes sôbre as fazendas de café. Até então eles forneciam livremente crédito aos fazendeiros, geralmente $12 \%$, e quase com a mesma facilidade renovavam tais fornecimentos. Mas, por volta de 1885, os capitais de repente diminuíram [...]"

${ }^{306}$. Ibidem, p.233. Segundo Morse, "não se deve crer, entretanto, que estivesse surgindo uma estrita dicomia entre uma burguesia da cidade e um patriciado rural, tal como aconteceu nos tempos coloniais entre os negociantes portugueses e os barões do açúcar do Norte do Brasil. Pois com as estradas de ferro, os fazendeiros de café, acostumados a morar nas suas propriedades ou nas cidades pequenas das redondezas, podiam agora gozar de uma vida mais confortável e mais animada na Capital, continuando em estreito contato com suas fazendas. Como moradores da cidade possuidores de riqueza, prestígio social e instrução de nível superior, muitos dêles ingressaram em atividades econômicas urbanas - como diretores de estradas de ferro, pioneiros da indústria, banqueiros etc. ou em profissões com que estavam familiarizados desde os tempos de estudantes, tais como as lides forenses, a política ou jornalismo. (entretanto, poucos ou mesmo nenhum fazendeiro se tornou corretor ou comissário.) Os estrangeiros, de que classe fôssem, a maioria dos brasileiros, eram muito mais fàcilmente identificáveis em interesses sòmente urbanos ou somente rurais.” 
sobre os preços também seja um múltiplo daquela decorrente diretamente da localização de novas indústrias." 307

No ritmo da industrialização, loteamentos e construções começaram a espocar por toda a cidade de São Paulo. Segundo Monbeig, “quanto mais progride a industrialização mais se acelera o ritmo das construções, enquanto se precipita o êxodo rural que conduz a São Paulo massas de operários.” 308.

A valorização da terra na Penha desencadeia-se, sobretudo, a partir de 1922 quando surgiram os loteamentos das vilas Esperança (1922 - entre a estrada velha de São Miguel e a linha férrea Central do Brasil) e Matilde (entre o curso dos rios Guaiaúna e Aricanduva $)^{309}$ como podemos verificar no Mapa 5 na página seguinte.

Deixemos claro aqui que, ainda no final do século dezenove, o primeiro terreno a ser transformado em loteamento foi a localidade conhecida por Guaiaúna (Vila) que se encontrava localizada ao lado do riacho de mesmo nome e bem próxima à estação Guaiaúna. Segundo Azevedo, em 1922, tirando o topo da colina onde se encontrava o centro da Penha e esses três loteamentos (Guaiaúna, Vila Matilde e Vila Esperança), que o autor identifica domo "núcleos satélites", eram encontrados “apenas pastagens para o gado e matas de onde se extraía lenha". ${ }^{310}$ Tal condição reafirma o isolamento da localidade assegurando mais alguns anos de sobrevida do caráter suburbano da localidade.

307. SINGER, P., op. cit., 1974. p.64-65. Segundo Singer: “A valorização da terra em São Paulo é um processo contínuo, que se desenrola, com intensidade crescente, há vários decênios, cria-se uma expectativa de que esta valorização prossiga no futuro e a um ritmo cada vez mais rápido. Essa expectativa determina uma demanda adicional por terra cujo fim único é usufruir dos ganhos diferenciais decorrentes da valorização do solo. Esta procura pode ser considerada especulativa 'pura' d984, a terra, pois mesmo na demanda com fins de utilização (industrial, comercial, residencial, etc.) do terreno, o elemento 'expectativa de valorização futura' entra em certa medida. $O$ efeito da procura especulativa 'pura' é elevar ainda mais o preço da terra, já que: a) ela se soma à procura especulativa 'impura', e b) ela restringe artificialmente a oferta ao adquirir terrenos que são conservados fora do mercado à espera de valorização [...] A especulação consiste, no fundo, numa antecipação das economias externas que, num prazo previsível, deverão beneficiar determinada área $e$ deste modo valorizá-la. O curioso é que sua própria ação a auto-alimenta, já que ao ocasionar aumento do preço da terra, ela justifica uma elevação da procura especulativa, pois a valorização presente prenuncia a valorização futura. Evidentemente, este processo não pode prosseguir indefinidamente, por assim dizer, girando no vazio. O capital para especulação é limitado e quando ele se esgota o especulador precisa parar de comprar e começar a vender. E é nesse momento que ele vai verificar se a especulação tinha base na realidade, isto é, se as vantagens relativas da área aumentaram desde a ocasião da compra."

${ }^{308}$. MONBEIG, P., op. cit., 1958, p.191.

${ }^{309}$. AZEVEDO, E. A., op. cit., 1945, p.75. Segundo o autor, durante o século dezenove as terras que deram origem à Vila Esperança pertenciam ao Dr. Gabriel Rodrigues dos Santos, sendo que após a partilha da herança do mesmo 1872, as terras passaram para as mãos de Maria Carlota de Melo Franco de Azevedo. Em 1922 ela disponibilizou para loteamento. Quanto a Vila Matilde, foi negócio de José Manoel da Fonseca Júnior.

${ }^{310}$. Ibidem, p.74. 
Em 1926 é inaugurado o loteamento Vila Aricanduva, ao sul da linha férrea na encosta setentrional do vale do rio Aricanduva, de fácil visualização no mapa 5 na página seguinte.

O autor ainda afirma que até 1930, "esses eram os pontos mais avançados da metrópole paulistana, nessa direção [Leste - Central do Brasil], vindo depois deles os grandes espaços desabitados, que anunciam o início da zona rural." ${ }^{\text {311 }}$ Reforçamos aqui a condição de subúrbio para a o bairro da Penha nesse período de sua história, ou seja, de fronteira entre o campo e a cidade.

Como aconteceu com outras localidades que acolhiam operários, os loteamentos da década de 1920, somente foram possíveis graças a ação de agentes financeiros que ofereceram para os mais carentes facilidades de pagamento dos lotes adquiridos. ${ }^{312}$

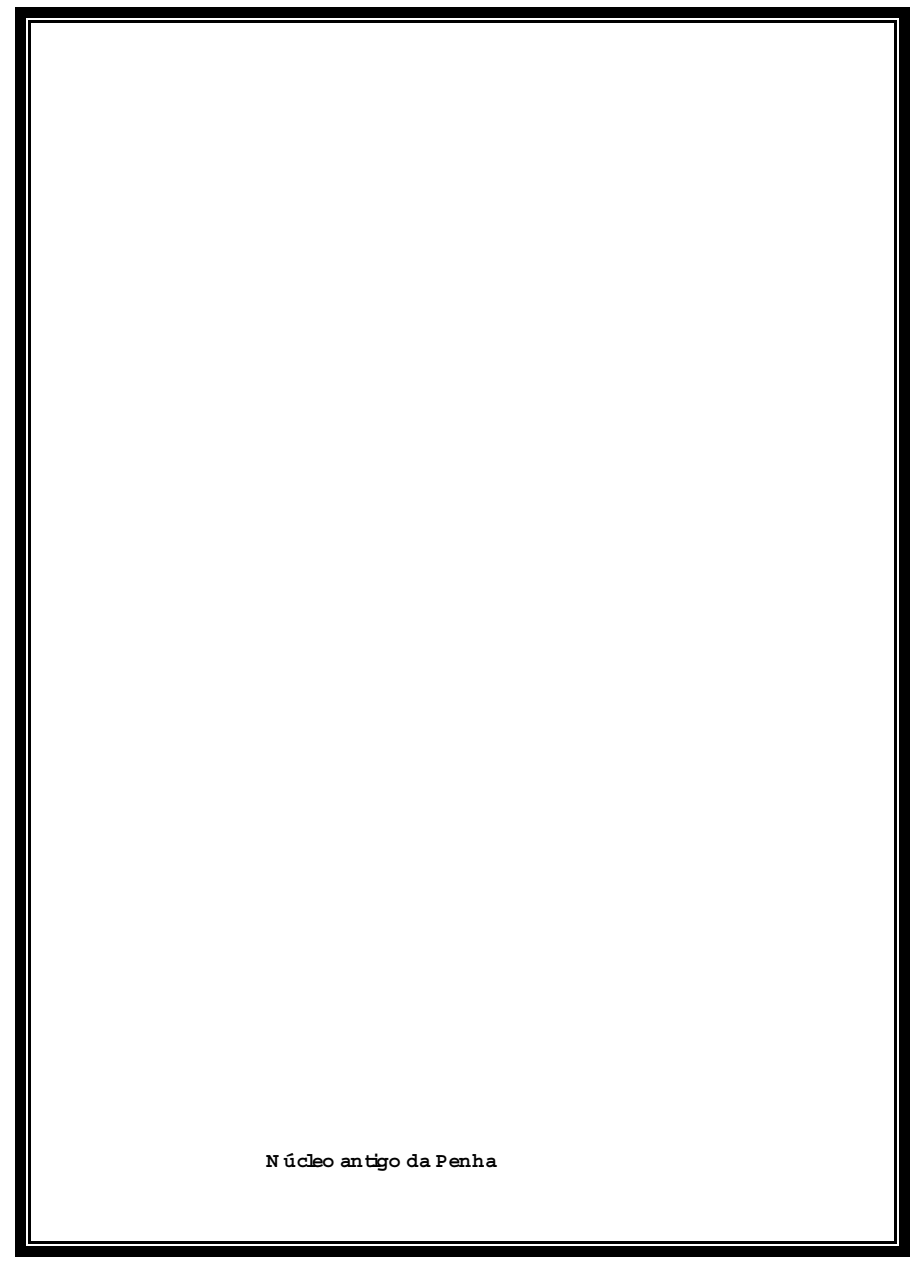

\footnotetext{
311. Ibidem, p.75. Os terrenos da Guaiaúna não foram de imediato parcelados em pequenos lotes; viraram primeiro terrenos de quadra e ali chegou a ser instalada casa de repouso para tuberculosos.

${ }^{312}$. SAMPAIO, M. R. A. de, op. cit., 1994, p.22-23.
} 
Mapa 5 - Loteamentos na Penha na década de 1930 (Guaiaúna, Vila Matilde, Vila Esperança e Vila Aricanduva). Fonte: AZEVEDO, E. A., op. cit., 1945, p.76 (Adaptação: Edson Penha de Jesus)

O processo se intensificou ainda mais ao longo da década seguinte e outros loteamentos surgiram: Vila Centenário, Vila São Geraldo e Vila Santana, esta última servida pela estrada de rodagem São Paulo-Rio e, outrora, parte integrante da fazenda de onde se originou a Vila Esperança. ${ }^{313}$

Como podemos observar no Mapa 5, os loteamentos ocorrem no entorno do núcleo central e nas proximidades da estação Carlos de Campos. No entanto em direção à cidade ainda persistiam grandes vazios.

As baixadas entre os rios Tatuapé e Aricanduva ainda sofriam com as cheias.

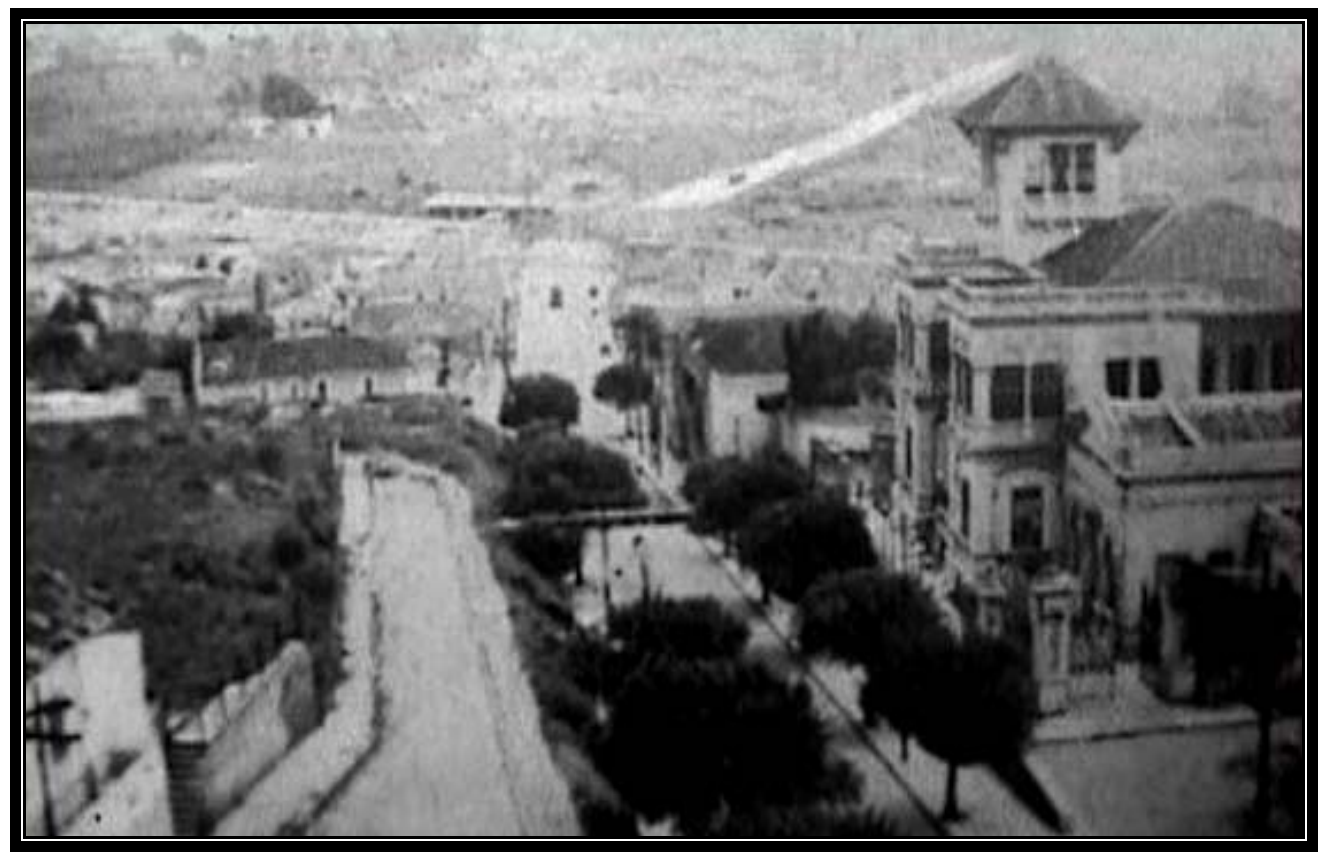

Ladeira da Penha (Atual Avenida Cel. Rodovalho) em 1920. Vista da torre da Igreja, ao fundo a Avenida Celso Garcia, as chácaras do vale do rio Aricanduva e as obras da variante Poá da Central do Brasil; à direita o palacete Rodovalho e à esquerda a Rua da Estação. Entre as árvores e sobre a Ladeira temos o pontilhão que ligava a mansão à antiga Estação Penha. (Memorial da Penha de França, acervo digitalizado)

Até então, a várzea do Tietê impedia o crescimento do bairro, porém a partir de 1926, com a inauguração da 'variante de Poá’ outros loteamentos surgirão entre a Penha e São Miguel. Além de intensificar a ocupação de áreas como a colina do Cangaíba, favoreceu a instalação dos loteamentos Vila Mesquita, Vila Londrina, Jardim Piratininga, Vila Rui Barbosa e Jardim Matarazzo. ${ }^{314}$

${ }^{313}$. LANGENBUCH, J. R., op. cit., 1971, p.133.
314. Ibidem. 
Em 1935, com a instalação do complexo industrial Nitro-Química em São Miguel Paulista, acelera-se a ocupação das terras ao longo da 'variante se Poá'.

No domínio da 'Central do Brasil', entre 1925 a 1935, a sudeste da Vila Matilde apareceram as vilas Eulália, Dalila e Talarico e a leste da mesma, sempre acompanhando a ferrovia, as vilas Ré e Santa Tereza. ${ }^{315}$

Na mesma época teremos ainda as vilas Manchester e Carrão ao sul e à sudoeste do centro da Penha.

Azevedo observou que, na década de 1930, o aspecto dos aglomerados urbanos da região oferecia

[...] grandes semelhanças: ruas não calçadas e em ladeiras (às vezes abruptas das colinas do terciário); casas mais ou menos dispersas; hortas para consumo particular; falta d'água e pequenas Igrejas com pouca significância; população composta de brasileiros, lusos e espanhóis. ${ }^{316}$

Analisando a expansão da cidade de São Paulo do período, Langenbuch, considera como característica geral a “escassez de ocupação da maior parte dos loteamentos,”317 pois apresentavam "não mais de uma dezena ou duas dezenas de casas. Alguns, de localização mais privilegiada - junto às ferrovias - conheceram melhor sorte. Na realidade esse imenso cinturão excedia, várias vezes, às necessidades imediatas e próximas da Capital. „318 Acreditamos que não tenha sido diferente nas imediações da Penha. Muitos dos novos loteamentos aqui citados não se encontravam próximos às estações ferroviárias, assim, atraiam poucos moradores e passavam algum tempo com poucas habitações. Esses loteamentos aceleravam a ocupação somente depois que um anterior, logicamente mais próximos dos meios de transportes e dotados de maior infraestrutura, começasse esgotar sua oferta de lotes.

Para Antônio Rocha Penteado, na década de 1930,

[...] o aumento dos impostos territoriais veio onerar sobremaneira as grandes propriedades, de que resultaram numerosos loteamentos e, em conseqüência, a proliferação de uma grande quantidade de 'vilas' suburbanas, quase todas tipicamente residenciais e habitadas por operários ou modestos funcionários públicos, cujas atividades são exercidas na Capital. ${ }^{319}$

Para o mesmo período afirma Langenbuch,

[...] sem dúvida a mencionada majoração fiscal se acha ligada à valorização fundiária, provocada de uma parte pela pressão exercida pela cidade sobre sua periferia, e de outra parte grandemente ampliada pela especulação imobiliária, graças a qual havia sempre um gigantesco mercado comprador, formado por

315 . Idem.

316 . AZEVEDO, E. A. de, op. cit., 1958. p.78.

317. LANGENBUCH. J. R., op. cit., 1971, p.137.

318 . Idem.

319. PENTEADO, A. R. Os Subúrbios de São Paulo e suas funções. Ed. Nacional. São Paulo, 1958. p.09. 
pessoas que adquiriam terrenos somente pela assegurada valorização que lhes permitiria auferir grandes lucros na revenda. ${ }^{320}$

Não sendo de outra forma, mais arruamentos e loteamentos surgem para satisfazer os interesses capitalistas. A grande maioria destes arruamentos e loteamentos não seguia nenhum 'plano conjunto’. Ao observarmos material cartográfico da região encontramos algumas raras exceções ao traçado enxadrezado padrão. Como podemos observar no Mapa 5, o loteamento Vila Matilde foi um dos poucos a respeitar a disposição do relevo na região.

Como já foi possível observar, o problema dos transportes era o que mais afetava a comercialização dos loteamentos. A colina da Penha era rodeada de várzeas alagadiças que atrapalhavam a implementação de meios de transporte mais eficientes e complicavam demais a vida dos que moravam longe das estações ferroviárias.

Segundo Langenbuch, na década de 1930, a 'Central do Brasil' contava com oito trens ligando São Paulo a Mogi das Cruzes. Mas esses trens favoreceram apenas a população que se concentrava em loteamentos próximos às estações, nos chamados ‘subúrbios-estação’. Aqueles que moravam distantes da ferrovia viam-se obrigados a longas caminhadas. Relata o autor que os ‘trens de subúrbio’ constituíram ótimo meio de transporte para o centro de São Paulo e para a faixa industrial de beira-linha, mas não para a porção central de bairros como a Penha. ${ }^{321}$

Ter a ferrovia como único meio de transporte de massa para a região de nada interessava aos agentes loteadores, assim desde o começo do século procurava-se resolver o problema dos espaços que ficavam distantes da ferrovia. As melhorias das vias e as instalações de linhas de bondes elétricos e depois ônibus que ligassem a Penha à cidade São Paulo e a Penha aos diversos novos loteamentos tornou-se regra.

Desse modo os bondes elétricos, começaram a adquirir papel de destaque como transporte coletivo na região. Segundo Santarcangelo,

[...] a linha 6 - Penha, a princípio contava com três secções: Belém, Tuiuti e Penha. Posteriormente, passou a existir uma única secção, direta até a Penha. A tarifa, apenas duzentos reis. O 'reboque' ou 'cara dura' era um bonde menor, anexado ao principal, geralmente pintado de verde, para melhor identificação. Sua passagem custava cem réis e era muito procurado por estudantes, os eternos 'prontos' ou pessoas humildes, de poucos recursos ou por 'pão duro' mesmo. Daí, o apelido recebido. Os bondes, no princípio do século, em virtude do longo trajeto, das inúmeras paradas e da proverbial cortesia de motorneiros e cobradores, caracterizavam-se pela sua morosidade. ${ }^{322}$

${ }^{320}$. LANGENBUCH, J. R., op. cit., 1971, p.137.

${ }^{321}$. Ibidem, p.160.

${ }^{322}$. SANTARCANGELO, M. C. V., op.cit., 1968. s/p. 
Tamanha foi a importância das linhas de bonde que, mesmo sendo morosos, proporcionaram uma intensa valorização das áreas próximas à Avenida Celso Garcia e também a extinção do Ramal da Penha da 'Central do Brasil'. As linhas de bondes elétricos que se dirigiam à Praça Oito de Setembro ${ }^{323}$, no centro da Penha, cortavam, em seu percurso, bairros industrializados como o Brás e o Belém e terminavam (ou iniciavam) na atual estação Roosevelt.

O que gerava morosidade para os bondes era as diversas paradas para pegar passageiros na região das chácaras dos vales do Aricanduva e Tatuapé e a famosa porteira do Brás, uma espécie de cancela que interrompia o fluxo de veículos para a passagem dos trens de subúrbio e de carga. Segundo entrevista com o Sr. Fábio a porteira era o grande sofrimento de quem pegava o bonde,

Ah! Demorado! Ás vezes era quarenta minutos, às vezes uma hora e meia. Tinha vez até de duas horas. O senhor chegava ali na porteira do Brás, era o inferno. O Bonde já tinha (?) de parada até a rua Bresser. Então a porteira abria, e ai, após, quatro, cinco minutos, fechava outra vez... E... Melhorou depois que fizeram ali aquele viaduto. ${ }^{324}$

Nem bem os bondes elétricos haviam se consolidado na região e outro sistema de transporte coletivo se fortaleceu: o ônibus.

Em 1935, a cidade de São Paulo já contava com 62 linhas municipais, número superior ao das linhas de bondes, e a Penha foi beneficiada por uma dessas linhas. ${ }^{325}$ Através dos referidos ônibus, estruturaram-se relações funcionais entre os 'subúrbiosestação’, os núcleos dos bairros distantes destes e outros loteamentos mais afastados. Nesse caso, podemos enquadrar as linhas de ônibus Penha - Guarulhos, Penha - São Miguel, Vila Esperança - Penha - Centro de São Paulo (linha inaugurada em 1925), Vila Matilde - Penha - Centro de São Paulo (1939), Jardim Popular - Penha - Centro de São Paulo (1939). ${ }^{326}$ Conforme Langenbuch, “o sistema suburbano de ônibus constitui mais um fator a conferir uma vocação de centralidade a alguns bairros periféricos paulistanos, que posteriormente iriam evoluir ao status de 'subcentros’.,„327 A Penha apenas reforça sua centralidade.

\footnotetext{
${ }^{323}$. Segundo entrevista com Sr. Pacha: "Mesmo do centro da Penha, tinha o retorno. Que era uma espécie de um círculo e o bonde vinha ali pela [rua] Comendador Cantinho, entrava no centro da Penha, dava a volta e voltava pela [rua] Comendador Cantinho mesmo.”

${ }^{324}$. Sr. Fábio. Entrevista concedida a Edson Penha de Jesus. São Paulo, março de 2002.

${ }^{325}$. LANGENBUCH, J. R., op. cit., 1971, p.160.

${ }^{326}$. Idem.

${ }^{327}$. Idem.
} 


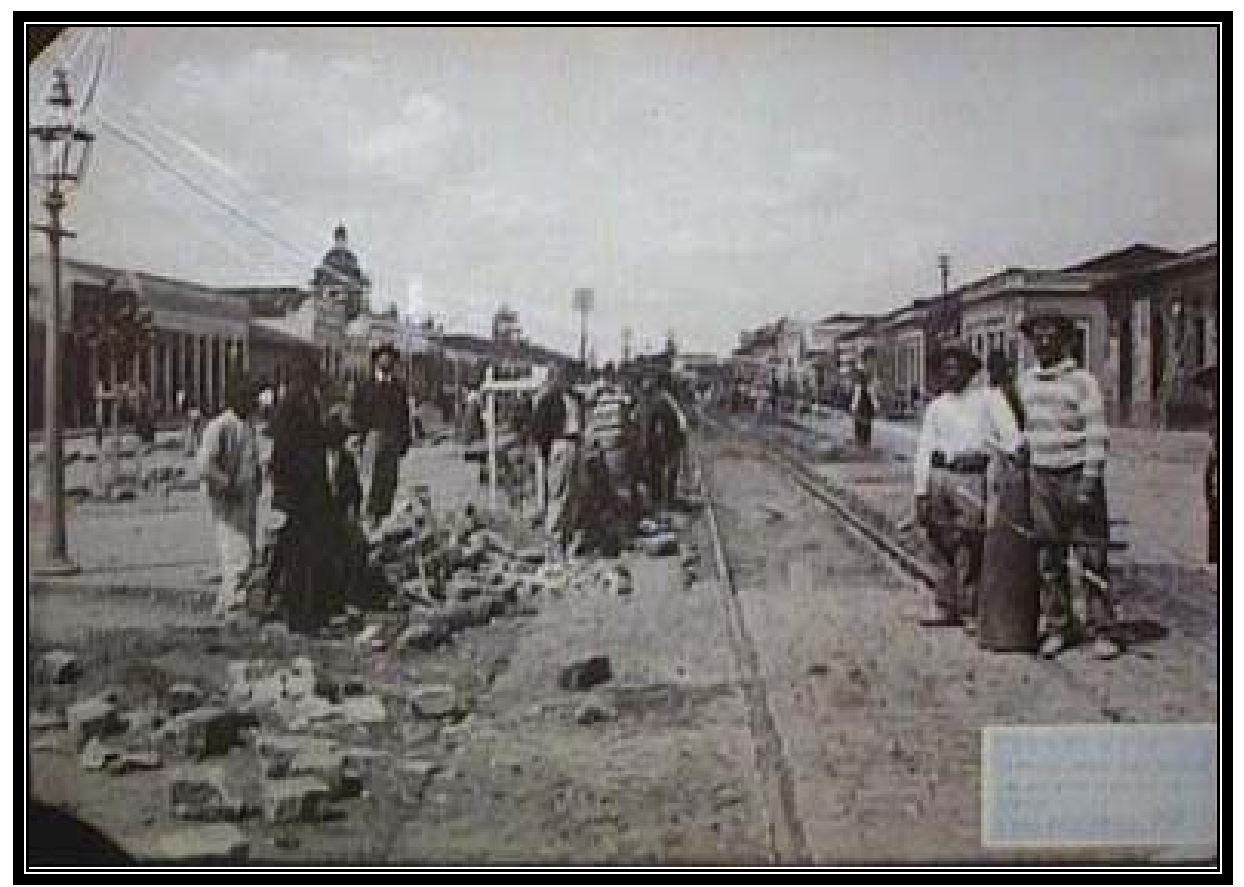

Operários assentando os trilhos na Avenida Rangel Pestana (Brás) para a futura linha para a Penha.

(Memorial da Penha de França, acervo digitalizado)

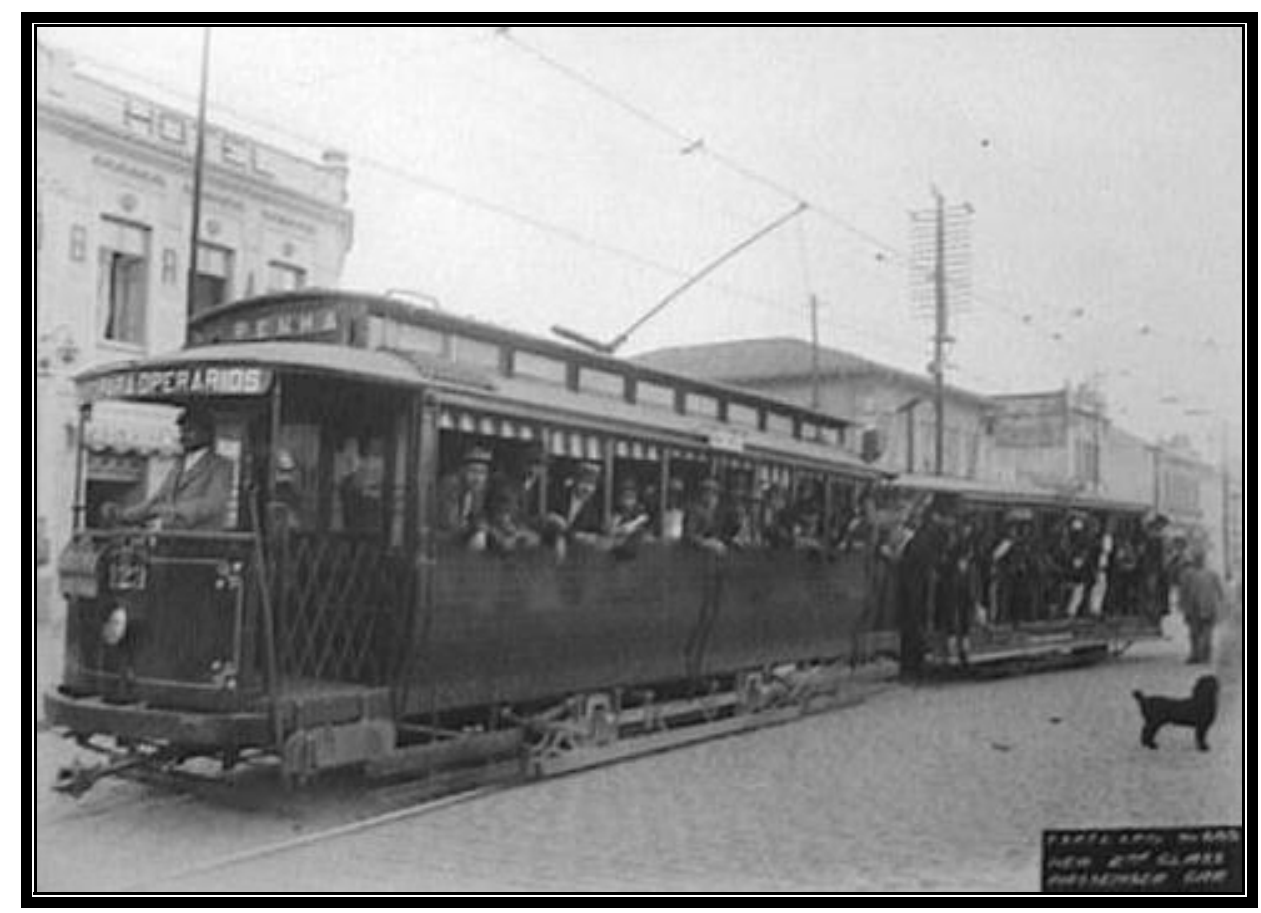

Bonde elétrico para a Penha no Largo do Tesouro em 1916.

(Memorial da Penha de França, acervo digitalizado)

A chegada do ônibus repercutiu diretamente sobre a expansão urbana na localidade. Na Penha, eles circulavam pelas vias estreitas e mal conservadas e ligavam os loteamentos próximos ao centro do aglomerado. Desta forma, segundo entrevista,

[...] um ônibus que saía aqui do..., vinha até aqui na Penha, era o ponto final. Ia para Guarulhos, outro ia para a Vila Esperança. Depois começou a 'vim' o São Miguel. Eram ônibus de, muito demorado, não era assim como existe hoje, 
ônibus constantes, passa um, já vem outro. Eu lembro que tinha horário, 'né’? Era só esses bairros: Guarulhos, São Miguel [...] Eu não me lembro se tivesse mais não. Não me lembro. Pra você ir, por exemplo para Itaquaquecetuba, Poá, era de trem. ${ }^{328}$

No começo não havia ônibus para o centro da cidade, a circulação partia da porção central da Penha e seguia para os loteamentos e cidades vizinhas. Aliás, todas as vias locais eram originárias do centro penhense. Para exemplificar, podemos citar as Avenidas Amador Bueno da Veiga, Avenida Cangaíba, Estrada da Conceição de Guarulhos (atual Avenida Gabriela Mistral), Rua Itinguçu e outras. Paralelamente a essas vias surgirão mais loteamentos: Vila Salete, Vila Ré, Vila Penteado, Vila Franci, Vila Buenos Aires e muitas outras.

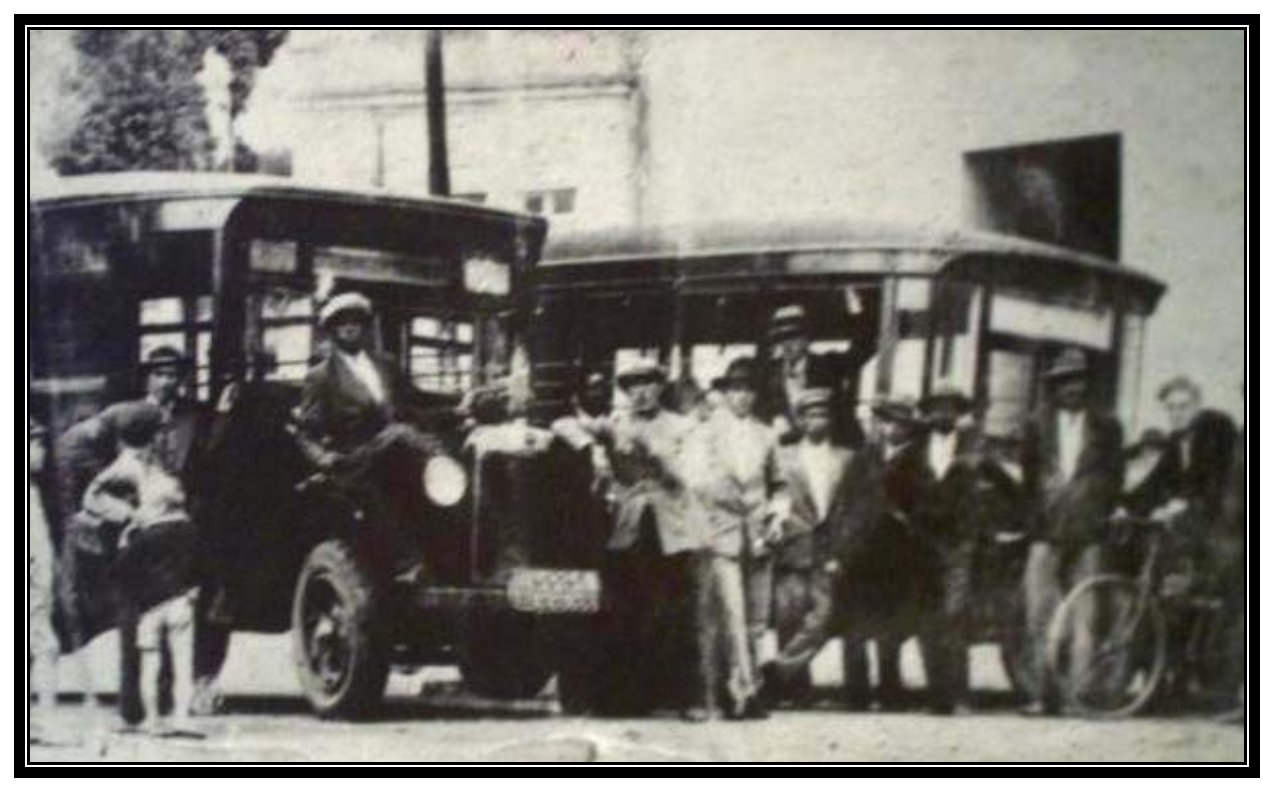

Largo do Rosário em 1928, ponto inicial da linha de ônibus Penha - Guarulhos.

(Memorial da Penha de França, acervo digitalizado)

Langenbuch conceitua esses loteamentos como 'subúrbios-loteamento' (periféricos aos 'sub-centros’ isolados); para ele “sua implantação precisa - em escala local - se deu em função de nenhuma polarização determinada por elemento geográfico, mas se deve tão somente ao fato de uma determinada área - e não uma área vizinha - ter

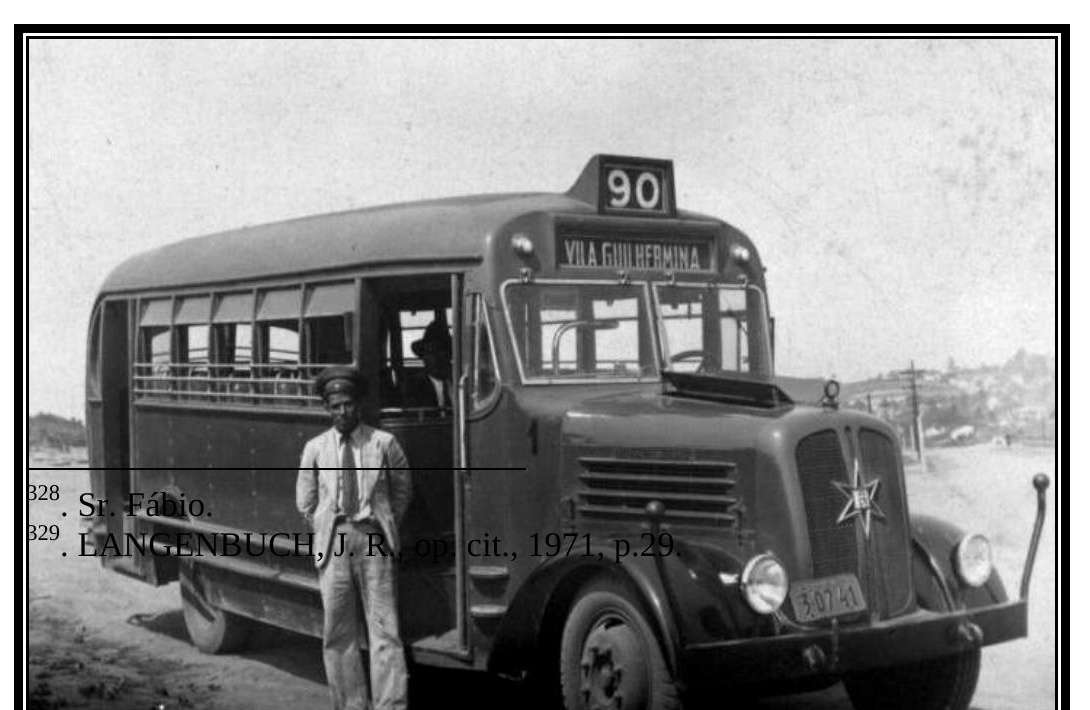
sido loteada e vendida em primeiro lugar, ou com maior promoção publicitária”329 
Ônibus Penha-Vila Guilhermina em 1939. (Memorial da Penha de França, acervo digitalizado)

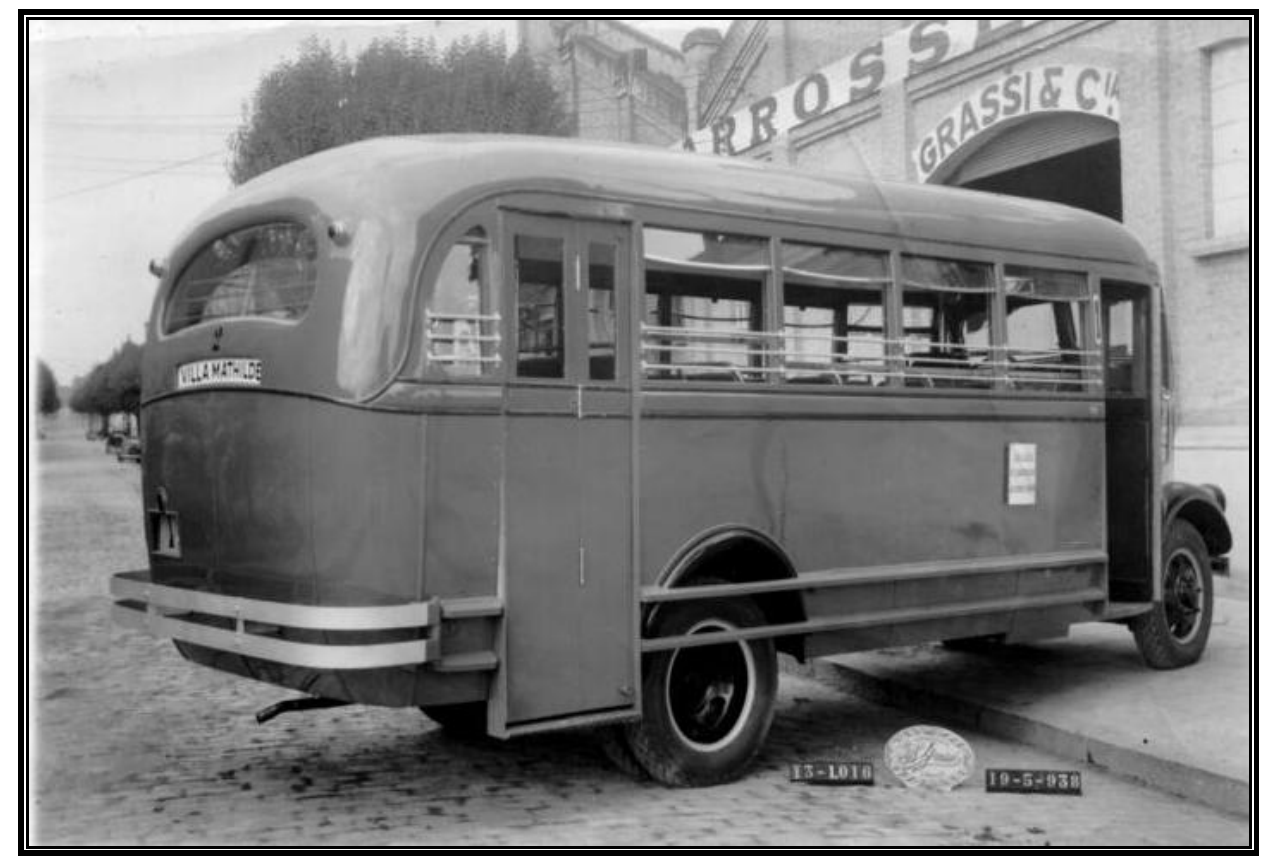

Ônibus Penha-Vila Matilde em 19 de maio de 1938 - fotografado na porta da fábrica de carrocerias Grassi \&

Cia (Avenida Presidente Wilson - Ipiranga) na data de entrega para uso. (Memorial da Penha de França, acervo digitalizado)

\section{Langenbuch ainda esclarece que:}

[...] em comparação com os 'subúrbios-estação', os 'subúrbios-loteamentos' se caracterizam por apresentar uma polarização interna menos acentuada. As vantagens oferecidas pelo ônibus não se concentram em torno de um ponto, como acontece com a estação ferroviária, mas se dispersam ao longo da rua ou estrada percorrida. Os pontos de parada são múltiplos. O equipamento comercial que surge tende a uma dispersão linear, ao longo do trecho da rua ou estrada que o ônibus percorre no interior do 'subúrbio-loteamento'. O ponto final do ônibus constitui o maior pólo em potencial, pois a ele afluem os moradores de toda a porção mais afastada do subúrbio, não alcançada pelo veículo (concentração comercial e de serviços). Com o crescimento do subúrbio a linha de ônibus acaba por ser prolongada, surgindo semelhantes pólos mais para a frente, firmando-se assim a tendência à dispersão linear dos aludidos. ${ }^{330}$

No final da década de 1940, surgem, ainda, mais núcleos considerados 'subúrbios-

estação’: a leste da Vila Esperança, surgem a Cidade Patriarca, junto à estação do mesmo

${ }^{330}$. Ibidem, p.159. 
nome, a Cidade A. E. Carvalho e Artur Alvim, consecutivamente. Na 'variante de Poá', instalam-se as indústrias 'Celosul' e 'Cisper', criando outros núcleos e algumas vilas industriais como a Vila Císper. À medida que surgem mais loteamentos, maior é a compactação urbana em torno da antiga colina.

\subsection{Aspectos socioculturais do subúrbio penhense até a década de 1930}

Como já estudamos, poucas alterações espaciais se processaram na Penha das duas primeiras décadas do século vinte. A ocupação se processava lentamente, a população era pequena e ainda predominava o uso rural do solo. Os loteamentos já eram comercializados na localidade e começavam a atrair operários (na maioria imigrantes) e seus familiares.

A Igreja ainda era referência sociocultural e, na medida do possível, esforçava-se para se manter no centro das decisões políticas do bairro.

A Penha, enquanto subúrbio apresenta-se como mescla de rural e urbano, tanto nas atividades econômicas quanto nas sociais tendendo a acelerada dominação do primeiro pelo segundo. Na Igreja, os resquícios do rural representado pelo catolicismo rústico estão sendo superados por práticas, digamos, mais urbanas, no caso, o catolicismo oficial. A Romanização era o cerne deste processo.

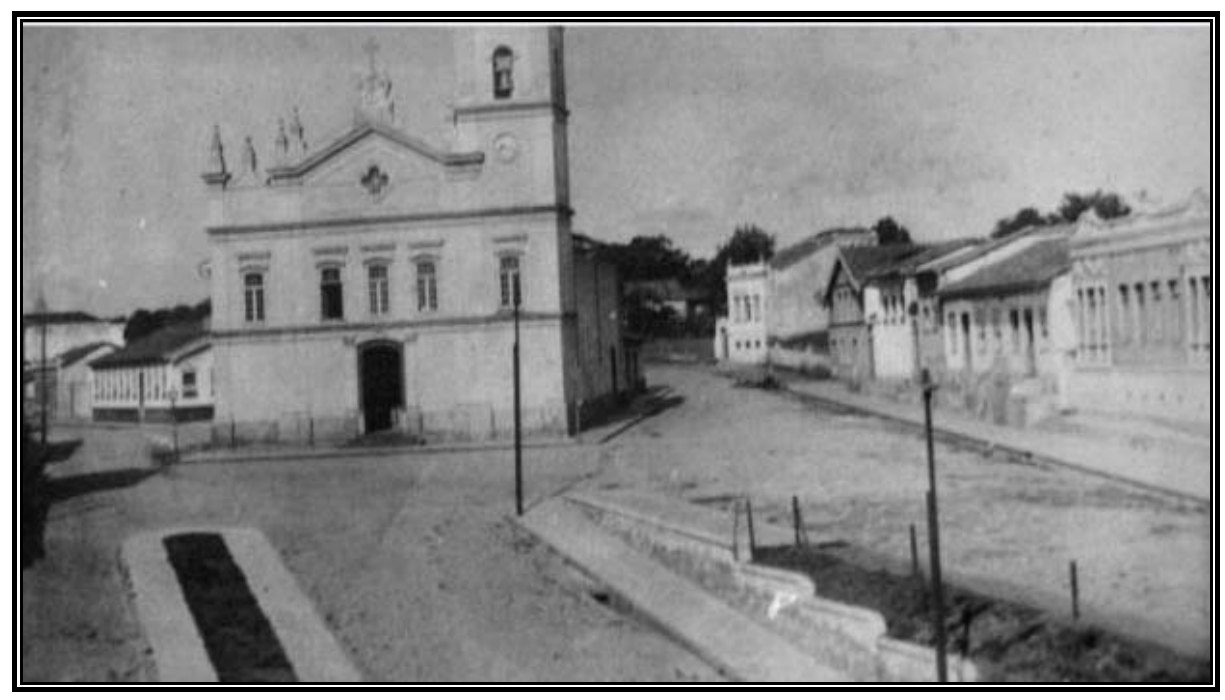

Igreja e Praça Nossa Senhora da Penha em 1908 - Atrás e à esquerda, onde hoje encontramos o Colégio São Vicente de Paula, podemos ver o convento das irmãs vicentinas (Memorial da Penha de França, acervo digitalizado) 
Já introduzimos o processo de Romanização no primeiro capítulo, no entanto sentimos que neste momento tal conhecimento precisa ser aprofundado, pois tem grande reflexo sobre o desenvolvimento social da localidade. O processo de Romanização trás consigo grandes transformações culturais para a Penha, pois, junto ao processo de urbanização e industrialização, contribui para o fim das relações de vizinhança na localidade.

A Romanização apareceu como uma espécie de nova ordem à religiosidade, a ordem distante, a ordem da Santa Sé, e veio carregada de posturas com finalidades claras: apagar qualquer resquício do catolicismo rústico e eliminar aqueles ritos e crenças populares que sobreviveram no país por séculos; no caso da Penha, aqueles que se estruturaram no bairro rural e que resistiram à pressão dos padres quando foi estabelecida a qualificação de freguesia para a Penha; aqueles ritos e crenças que representavam a antiga ordem, a ordem local, e que sobreviveram mesclados ao catolicismo oficial.

A Romanização penhense, personalizada na figura dos padres redentoristas, vem para ‘civilizar’ o catolicismo penhense. Parecia até que a Romanização coincidia com as necessidades socioeconômicas impostas pelos processos de urbanização e industrialização que ocorriam na cidade de São Paulo.

O processo de Romanização empreendido pelos padres redentoristas procurava reestruturar as práticas religiosas da localidade ${ }^{331}$. Os sacerdotes redentoristas, na maioria de origem européia ${ }^{332}$, encaminhados desde 1905 para a igreja da Penha tinham objetivos bem definidos: assegurar e agilizar a hegemonia do catolicismo oficial na localidade, definir e confirmar novas estratégias de controle ideológico e político do espaço urbano penhense e substituir definitivamente o tradicionalismo das práticas dos antigos vigários do século dezenove. ${ }^{333}$

Diante da nova conjuntura socioeconômica brasileira, os espaços considerados sagrados na Penha, como a igreja e o adro, se apresentavam cada vez mais fragilizados diante dos interesses mundanos. A Igreja se via cada vez mais acossada na luta pela

${ }^{331}$. LINGUITTE, Hedemir - Santuário de Nossa Senhora da Penha. São Paulo, 1989(?). Segundo o autor, “a 05-03-1905, D. José de Camargo (então Bispo de São Paulo) entregou a Paróquia ao encargo dos Redentoristas, dando provisões ao Padre Lourenço Hubbauer, continuando o Padre Antônio Benedito de Camargo com o título de vigário colado com a côngrua do governo. Assim, quando o primeiro vigário redentorista tomou posse, a 05-03-1905, foram nomeados naquela ocasião, vinte sacerdotes de Santo Afonso, para trabalhar na Penha.” p. 41.

${ }^{332}$. BÔA NOVA, A. C., op. cit., p.37-39.Com a Proclamação da República, a separação entre Estado e Igreja trouxe muitos incômodos para o catolicismo brasileiro, entre eles, a redução do clero nacional. O Estado deixou de pagar soldos aos sacerdotes, o que tornou a carreira desinteressante entre os jovens das famílias mais abastadas impedindo a reposição daqueles que se aposentavam ou morriam.

${ }^{333}$. Ibidem, p.33. 
manutenção desses espaços. Cabia aos redentoristas estabelecer novas estratégias de controle, já que as antigas práticas de dominação não garantiam mais o controle físico de tais espaços. ${ }^{334}$

A Igreja procurava manter sua hegemonia a partir de duas formas intrínsecas de controle: o político-ideológico (carregado de representações, sentimentos, simbologias e misticismo) e o físico (palco para o desenvolvimento da religiosidade, espaço da procissão, da quermesse, do templo, do acolhimento religioso).

Assim, se justifica neste trabalho analisar alguns aspectos acerca da ação redentorista na Penha. Outro fator importante para tal análise é que tal ação revela algumas características importantes da passagem da cultura rural para a urbana da sociedade penhense.

Bôa Nova, ao analisar a prática dos redentoristas no país, afirma que

[...] as novas gerações de padres não se contentavam mais com o simples fato de o catolicismo ser a religião predominante. No seu entender, seria necessário a educação religiosa do povo, para assegurar a ortodoxia da fé, a freqüência às práticas rituais e obediência à hierarquia. ${ }^{335}$

Complementa Bôa Nova;

[...] esse objetivo tornava-se mais difícil de ser conseguido por uma Igreja que não estava mais unida ao Estado. A separação da Igreja e Estado libertara a hierarquia da incômoda interferência das autoridades civis em matéria religiosa. Em compensação, a Igreja fora excluída do poder. Do ponto de vista da hierarquia esta era a face indesejável da moeda [...] uma vez fora do poder, a Igreja passou a procurar caminho para voltar a ele. A condição de religião majoritária seria, então, invocada como argumento para justificar reconhecimento e apoio público para o catolicismo. Entretanto, a reconquista do poder requeria mobilização de grupos de pressão que atuassem sobre os governantes. Para isso, era preciso contar com a dedicação e a influência de numerosos padres e leigos. A preocupação com as vocações sacerdotais e a formação de um laicado fielmente submisso à hierarquia têm muito a ver com essa estratégia. ${ }^{336}$

A reaproximação com o poder laico apresentava-se como ponto irrefutável da estratégia da Igreja. Nesta prática, a festas, como as procissões e as quermesses, apresentavam-se como excelentes atividades para o desenvolvimento e fortalecimento de práticas religiosas, políticas e econômicas. Apesar dos conflitos de interesses, religiosos, políticos e comerciantes apresentavam-se juntos nas manifestações religiosas da Penha. Oliveira, ao analisar paróquias confiadas aos padres redentoristas de origem européia, afirma:

${ }^{334}$. No catolicismo popular, carregado de misticismo, o controle espacial apresentava-se muito mais eficaz. Porém, o controle imposto pelo vigário e toda a mística santa que o envolvia, já que se apresentava como representante direto do santo de reverência na terra, reforçado pelo Estado, havia se exaurido diante da República.

${ }^{335}$. Ibidem, p.37.

${ }^{336}$. Ibidem, p.38. 
[...] logo que chegam ficam impressionados com a reduzida afluência de fiéis à Missa dominical, enquanto constatam o grande interesse religioso despertado entre eles pelas festas de santos, mas desinteressados pelas atividades religiosas promovidas pela paróquia. O zelo que eles demonstravam na devoção aos santos contrastava com o seu relaxamento quanto à participação nos sacramentos e na missa dominical. Além disso, as famílias pareciam não interessar-se pelo catecismo das crianças. Diante desta situação que lhes parecia anômala, os padres trataram de difundir entre os fiéis a devoção a Nossa Senhora do Perpétuo Socorro. Falam de seus poderes, de seus milagres, de sua capacidade em interceder junto ao seu Filho e das grandes vantagens espirituais que ela concede a seus devotos. Pouco a pouco, cresce o número de fiéis interessados em se tornarem devotos dessa Santa, e os padres lhes dizem que podem fazer vir de Roma seu quadro bento pelo próprio Papa. Coletados os fundos necessários, os novos devotos fazem vir a imagem, que é recebida na paróquia com toda solenidade: fez-se novena, a preparação espiritual e, no dia da chegada, uma grande festa com procissão solene. O quadro é colocado num lugar de honra junto ao altar-mor, enquanto a antiga imagem de Nossa Senhora da Glória era discretamente removida para a sacristia. No mesmo dia abre-se a inscrição para a nova irmandade de Nossa Senhora do Perpétuo Socorro, congregando grande número de fiéis. [Estrategicamente] [...] tanto quanto possível preferiam não combater diretamente as devoções tradicionais, limitando-se a não participar delas e a condenar os excessos cometidos durante as festas de santos, como a dança, a bebida e o mau uso do dinheiro recolhido pelos devotos $[\ldots]^{337}$

Na Penha, o processo seguiu a mesma orientação.

O padre de origem alemã José Afonso Zartmann, terceiro vigário da ordem redentorista na Penha é um bom exemplo da ação redentorista local. Segundo Linguitte:

Padre Afonso mostrava-se tão devoto de Nossa Senhora da Penha e tão confiante na proteção da Virgem do céu, que jamais se fatigava em dizer que o único remédio para os males que afligiam aos paroquianos que o procuravam, era a de rezar pura e simplesmente uma Ave-Maria em honra da Virgem da Penha, não custava nada em o fazerem, acrescentava o sacerdote, eis que esta oração representava muito, na fé e na conquista de graças junto à Nossa Senhora, desde que bem rezada e bem meditada [...] desta maneira o bom vigário se mostrava ao mesmo tempo médico, conselheiro e assaz confortador, bastando que se recitasse uma Ave-Maria e que tudo, com isso se resolveria satisfatoriamente. A confiança admirável na intercessão e na proteção de Maria Santíssima, jamais veio a faltar nas palavras e na ação do Padre Afonso $[. . .]^{338}$

Desta forma, devagarzinho os padres redentoristas iam substituindo as obrigações consagradas a Nossa Senhora da Penha de França por obrigações a Virgem Maria, mãe de Jesus. Substituir obrigações não significava substituir uma Santa pela outra, não era esse o interesse: o objetivo era minguar a devoção pela Nossa Senhora da Penha e acabar com resíduos do catolicismo rústico na região a tal ponto que ela fosse, hierarquicamente, sobreposta pela adoração à mãe de Jesus. ${ }^{339}$

Assim, as novas associações religiosas foram sendo introduzidas na Penha e as antigas irmandades e confrarias foram sendo substituídas. As novas associações eram entidades fundadas e dirigidas por padres, e não como as anteriores que ficavam nas mãos de leigos, e todos os participantes estavam sob tutela eclesiástica. As antigas irmandades e

337 . OLIVEIRA, P. A. R. op. cit., p.285.

${ }^{338}$. LINGUITTE, H., op. cit., p.33-34. 
confrarias passaram a ser boicotadas e excluídas das diversas atividades ligadas à Igreja, rapidamente perderam seus seguidores e desapareceram. Segundo Oliveira:

Este é o ponto-chave no processo de romanização, pois os leigos não têm nelas o poder de decisão que vai para as mãos do vigário ou o assistente espiritual por ele nomeado é aquele que de direito ou de fato dirige a associação pia. Além dessas associações são fundadas também associações de finalidade caritativa e assistencialista, como as Conferências Vicentinas [...] o prestigio dessas novas associações paroquiais era reforçado pelas festas religiosas. Enquanto as festas tradicionais eram mal vistas pelos padres, que tudo faziam para esvaziá-las de seu conteúdo propriamente religioso, as novas festas religiosas eram confiadas às associações paroquiais. Assim, por exemplo, o mês de Maria era ocasião em que se destacavam as associações marianas, e as primeiras sextas-feiras o dia de glória do Apostolado da Oração. Os vigários, é claro, davam todo apoio a essas festas por eles mesmos promovidas, enquanto retiravam seu apoio às festas religiosas tradicionais, inclusive provocando choques com as associações leigas tradicionais $[\ldots]^{\prime 340}$

Segundo o Linguitte, em 05 de julho de 1908 nasce a Associação do Apostolado da Oração e em 6 de outubro do mesmo ano formou-se a Associação Pia União das Filhas de Maria da Penha, entre as jovens de sexo feminino da paróquia de Nossa Senhora da Penha. $^{341}$

E não parou por aí, para os padres redentoristas, quanto mais associações, melhor seria o controle: em 13 de maio de 1916, por iniciativa do então Vigário Padre Antão Jorge, aparece outra associação na paróquia, a Liga Católica Jesus, Maria, José. Além da criação de novas associações, outras mais antigas eram reorganizadas. Em 1919:

[...] muito aplaudida foi a idéia do R.P. José Clemente de reorganizar a Associação do Circulo Católico que cessara de existir na Penha em conseqüência da guerra [I Grande Guerra Mundial] e dos maus elementos, que nela havia. O P. José Clemente, porém, deu-lhe nova orientação, expulsou os elementos e chamou os bons e aos 11 de maio, festa do patrocínio de São José, inaugurou a nova fase da associação $[\ldots]^{342}$.

Podemos perceber que o processo de romanização não aconteceu de imediato.

O expurgo de pessoas, a introdução de novas crenças e a criação de associações, não eram as únicas estratégias de fortalecimento da Igreja na Penha. Ela precisava ainda se aproximar mais da população penhense. Assim, foram implementados diversos recursos que visassem aumentar a afluência de fiéis na localidade: eram festas comunitárias, reuniões das mais diversas finalidades, quermesses, excursões e até outros eventos como biblioteca e cinema. ${ }^{343}$ Os objetivos eram reforçar a Igreja como centro dos

339 . Ibidem, p.45.

340 . OLIVEIRA, P. A. R., op.cit., p.287.

${ }^{341}$. LINGUITTE, H., op.cit., p.45-46.

342. Cf. Livro Tombo da Freguesia de Nossa Senhora da Penha - Livro Códice 12-1-11, aberto em 1918, p.08.

343. Ibidem, p.09. Conforme o registro, “[...] com o fim de patrocinar ao povo da Penha algum divertimento inocente e ao mesmo tempo, de conseguir os meios necessários para a manutenção da associação dos moços que gostam de boa biblioteca, de jogos inocentes etc., foi no Salão São Geraldo instalado um 
acontecimentos sociais e fortalecer a agenda religiosa local. Voltaremos a esse ponto mais adiante.

As festas eram, sem dúvida, os principais momentos da comunidade. Na Penha do começo do século vinte ocorriam festas concorridíssimas, principalmente nos meses de agosto e setembro, quando se excedia em dezenas de vezes a população penhense, o que sem dúvida favorecia uma integração maior entre a cidade e a localidade. Era uma invasão de romeiros, visitantes e comerciantes de tudo quanto é canto da cidade e a Penha virava um apinhado de gente que rezava, comia, bebia, chorava, pregava, penitenciava e perdia dinheiro em jogatinas.

O trecho a seguir, recolhido do romance "Menino Felipe - Primeira Viagem” de Afonso Schmidt transporta-nos, por meio do imaginário, ao que seria uma destas festas na Penha de 1918:

Plás... Nada. Plás.

As carantonhas continuaram a rir com a boca banguela. Os ovos continuaram a oscilar na ponta dos barbantes. Na câmara negra, as armações de ferro continuaram a girar, a girar, com seus penduricalhos brancos. Meu pai levou a arma à cara, fez pontaria e disparou o último tiro. Plás... Um pito de barro desapareceu, em estilhas, na caixa negra do tiro-ao-alvo. O dono da Barraca veio lá de dentro e entregou-lhe um maço de cigarros 'Icaraí'. Pegou na espingarda que meu pai devolvia, colocou-a no armário, ao lado de outras, e se pôs a gritar para fora:

- Romeiros da Penha! Cinco tiros por um cruzado! Ricos prêmios! Que venham os bons atiradores! A festa da Penha era em 8 de setembro, mas começava muito antes. Para falar verdade, em qualquer dia do ano a gente sempre encontrava com que divertir-se. Tanto mais naqueles domingos deliciosos de agosto, de céu azul, as paisagens nítidas, de poeira dourada. Os trens partiam superlotados da Estação Norte. Pela estrada de rodagem da Penha, formavam-se cortejos de carroças cobertas de ramos verdes, enfeitadas de bandeirolas de papel de seda. Quando chegavam à subida do santuário, os romeiros deixavam os veículos à porta das vendas, botavam um feixe de capim diante dos burros e galgavam a ladeira, a pé, conduzindo grossas velas de cera. Desde manhã que as carroças passavam diante de nossas janelas. Algumas delas levavam famílias. Dançava-se e cantava-se com muita alegria. Meu pai estava lendo o ‘Comércio de São Paulo’. De repente, não resistiu à tentação.

- Úrsula, vamos passear na Penha?

Mas Úrsula era muito amiga das chinelas. Relutou. Êle insistiu. E acabou vencendo. Dali a pouco, nós quatro deixamos a casa e nos dirigimos à estação do Norte. Os trens partiam de hora em hora, apinhados de passageiros. Minha mãe sentou-se com Silvinho, junto à janela. Eu e meu pai ficamos de pé, num grupo de passageiros festivos. Foi uma viagem penosa, mas divertida. Chegamos na força do calor. A estação encontrava-se a meio quilômetro de distância, num corte praticado na colina. À chegada de cada trem, era uma gritaria, uma algazarra. Roceiros vendiam canas, batata doce assada, cuias de garapa e tigelinhas de quentão. Depois, os grupos se punham a caminho da igreja. Ouviam-se queixas de violão, risadas finas de bandolins. Os romeiros caminhavam devagar, colhendo flores dos arbustos que pendiam dos barrancos. Havia gente que parava para contar melhor caso. Ou para tirar o calçado, que lhe espremia os pés. Quando chegamos ao largo da igreja foi um deslumbramento.

cinema, que funcionará todos os domingos e dias feriados, sendo as fitas examinadas conscienciosamente. As primeiras exibições tiveram o mais completo êxito.” 
Muita barraca, muita gente. Não conseguimos entrar no templo. Então fomos passear. Já ao escurecer, entramos numa tenda do Largo São Benedito, perto da igreja velha, e jantamos carne de espeto, assada ali mesmo, à vista dos fregueses, e arroz com repolho e nacos de salpicão. Meu pai bebeu uma garrafa de cerveja Bavária e contou uma porção de anedotas. Dali voltamos ao Santuário. Como fosse hora de jantar, já não havia tanta gente lá dentro. o templo estava iluminado a giorno, como se dizia. Era como se sobre a sua fachada escura tivesse pousado um enxame de borboletas luminosas. Ao vento da praça, elas, como obedecendo uma ordem, agitavam as asas azul e ouro, com um crepitar macio, de papel de seda que se amarrota. As ruas e praças estavam ornamentadas com arcos de bambus. Nesses arcos, um baile de flâmulas, de bandeiras coloridas. E de lanternas chinesas, em fieiras curvas, que desciam da torre e iam terminar nas frontarias de algumas casas do largo.

Por toda parte, barracas de lona, de aniagem ou de zinco. Cozinhas improvisadas ao ar livre, onde pretas gordas, de avental e lenço na cabeça, faziam pastéis, cuscuz, cocadas, pé-de-moleque ou queijadinhas de coco, que tinham fama. Aqui vendia-se café a três vinténs, em canequinhas de louça branca. Mais adiante, apregoavam-se doces feitos em casa, cocadas brancas e mulatinhas, suspiros, mães-bentas, amendoim torrado, pipoca, geléia de mocotó e pires de arroz doce, avermelhados de canela, pintados pelas cruzetas de cravos da Î́ndia [...] O povo se aglomerava nos botequins embandeirados sobre cujo balcão se enfileiravam os ancorotes de aguardente com copiá, abútua, arruda, losna e os mais disparatados ingredientes. Os bebedores falavam alto, discutiam, escangalhavam-se de rir e, não raro, no calor da festa, um deles levava a mão à cinta, feita a ponto de lã de cores vivas, para averiguar se a lapiana ainda lá se encontrava. A guarda urbana vigiava as esquinas. De quando em quando, um sargento de banda vermelha pendendo de lado, atravessava a praça com ar solene. Era a autoridade.

Mas o forte da festa era a jogatina. Por toda parte, em barracões e ao relento, alumiados por lampiões de querosene, improvisavam-se pequenas batotas. Ouviase o rodar das roletas de latão, com cavalinhos numerados que galopavam incessantemente. Uma barbatana fixa indicava o vencedor. Mais adiante, aquele grito mil vezes repetido: - Olha o jaburu! Eram doze cartas arrumadas sobre a mesa. O banqueiro agitava freneticamente os dados dentro de uma caneca de folha. Muitos homens vinham da noite estrelada de lâmpadas e faziam roda na mesa. Num barracão mal iluminado e com cheiro de couro curtido, reuniam-se boiadeiros de botas, pala, lenço no pescoço e chapéu castanho de abas largas. Uns cantavam, outros ponteavam na viola, muitos jogavam. E o batoteiro gritava à porta: - Olha o jogo do caipira, quem mais joga mais tira! Lá estava o buso, que parecia bisavô da roleta. Era uma gamela, ou melhor, uma bacia de madeira, com o fundo cavado em funil. Essa geringonça repousava sobre quatro pés de madeira tosca, que se firmavam no chão batido. O banqueiro, depois de estabelecida a parada, fazia girar algumas bolas igualmente de madeira nos bordos da bacia. As esferas corriam descendo, descambando, até se aninharem no fundo da gamela. A cada rodada era uma festa, uma gritaria.

Mas a algazarra dos mercadores, dos batoteiros e peregrinos que cantavam ladainhas era, de quando em quando, abafada pela banda de música do Veríssimo que, no coreto da praça, tocava maxixes dos mais sapecas, como o 'Parafuso', o 'Canja de Bode' ou o ‘Corta Jaca'[...] $]^{344}$

O relato acima, revela-nos muito da sociedade, da economia e da religiosidade

penhense da época. Nas festas do começo do século vinte, sagrado e profano se confundiam no uso do espaço. Certamente que as barracas de jogatinas não eram a vontade da Igreja, mas proporcionavam grande afluência a aumentavam a arrecadação.

Apesar de a Igreja condenar tais práticas, como veremos adiante, elas ainda eram necessárias à subsistência da mesma na localidade. Lembramos que grande parte das

${ }^{344}$. SCHMIDT, Afonso. Menino Felipe, Primeira Viagem. São Paulo: Ed. Brasiliense Ltda, 1950, p.101-104. 
barraquinhas pertencia às diversas irmandades da igreja penhense e as demais eram autorizadas mediante o pagamento de taxa ao Estado.

À sua maneira, muitos ganhavam com as festividades religiosas na Penha: a Igreja, com o reforço material da fé; a população, porque as festas se apresentavam como uma das poucas possibilidades de lazer; comerciantes locais ou não, regularizados ou não, que tiravam seus lucros; o Estado, com impostos e aluguéis de espaços públicos; políticos, que se aproximavam de eleitores; as empresas de transportes; malandros de toda espécie; músicos e muitos outros. A festa ainda se apresentava como reunião de todos para todos, pois era freqüentada por toda sorte de indivíduos, de todas as classes, de todas as etnias e atraía gente de regiões longínquas.

Igreja, Estado e interesse econômico dividindo e disputando o espaço.

Nesta disputa, a Igreja penhense se sentia em desvantagem. Para o novo clero penhense do começo do século vinte, esse tipo de festa era um incomodo: não atraía fiéis, atraía apenas fanfarrões e jogadores, era preciso dar um basta. Os padres redentoristas solicitaram a D. Duarte Leopoldo e Silva (então Bispo de São Paulo) que interviesse junto às autoridades civis para fazer mudanças nas festas da Penha. ${ }^{345}$ Tal solicitação foi atendida de forma parcial porque, se interessava à Igreja, certamente pouco interessava aos demais agentes que participavam da festa.

O texto de Schmidt também nos revela alguns dados curiosos sobre a economia, a sociedade e a relação que se estabelecia entre a Penha e a cidade de São Paulo nas duas primeiras décadas do século vinte. Seriam eles: a) sobre os meios de transporte de ligação entre a cidade e o bairro: os trens que chegavam de hora em hora onde passageiros desciam na estação Guaiaúna, a “meio quilômetro de distância” do topo da colina, já que o ramal Penha havia sido desativado desde 1907; outro meio de transporte eram as carroças puxadas por burros que não chegavam a subir a colina; podemos supor que ficavam na várzea do rio Aricanduva, no final da Avenida Celso Garcia; b) além das diversas barracas, havia vendas (armazém comercial fixo que certamente atendia a população local em períodos não festivos); c) a falta de pavimentação; d) a presença do elemento negro nas atividades domésticas; d) o lazer sobrepondo-se à religiosidade; e) o texto ainda relata que o fluxo de pessoas para a Penha não se resumia apenas aos períodos de festividade, ocorriam de forma regular, pois o a localidade se apresentava como uma boa opção de lazer. f) a presença do Estado firmada pela guarda urbana; entre outros.

${ }^{345}$. LINGUITTE, H. op. cit., p.22. Segundo Linguitte: “depois que o então Bispo de São Paulo fez pé firme contra o jogo, nas festas da Penha, estas passaram a ter menos fastígio, na parte profana." 
Para uma cidade tão carente de diversões, o êxito de festividades como a penhense era inevitável, mas que fique claro, não pela religiosidade, mas pela possibilidade de lazer.

Fora do período de festas, o fluxo de pessoas que iam até a Penha somente se destacava no domingo, dia de descanso do cristão, quando a Igreja ficava abarrotada. Em 1918, segundo Livro Tombo,

[...] todos os domingos deste mês o templo regorgitava de fiéis, que vinham comprir as promessas feitas perante a gripe [Espanhola]. Muitíssimas pessoas tinham de ouvir a missa do pateo por não haver logar para elas dentro da Igreja durante as quatro missas que aqui se celebra todos os domingos e dias festivos. É por essas ocasiões que se nota a devoção que o povo da capital consagra à virgem da Penha. ${ }^{346}$

Segundo resumos anuais das décadas de dez e vinte recolhidos dos Livros Tombos, a anfluência à paróquia da Penha crescia a cada ano:

\begin{tabular}{lccccccccc}
\hline \multicolumn{7}{c}{ RESUMO DAS ATIVIDADES DA PARÓQUIA DE NOSSA SENHORA DA PENHA ENTRE 1904 E 1929 } \\
\hline ANO & $\mathbf{1 9 0 4}$ & $\mathbf{1 9 1 9}$ & $\mathbf{1 9 2 0}$ & $\mathbf{1 9 2 2}$ & $\mathbf{1 9 2 3}$ & $\mathbf{1 9 2 6}$ & $\mathbf{1 9 2 7}$ & $\mathbf{1 9 2 8}$ & $\mathbf{1 9 2 9}$ \\
\hline Comunhões & -- & 22.425 & 32.264 & 35.560 & 27.290 & 43.815 & 52.607 & 58.513 & 64.831 \\
\hline Batizados & 227 & 1.036 & 1.621 & 2.296 & 2.700 & 3.910 & 4.982 & 5.101 & 4.960 \\
a) da paróquia & & 468 & 553 & -- & 920 & -- & -- & -- & -- \\
b) de fora & & 568 & 1.068 & -- & 1.780 & -- & -- & -- & -- \\
\hline Extrema-unções & 23 & 65 & 27 & 76 & 100 & 162 & 167 & 138 & 125 \\
\hline Catecismo & -- & 665 & 800 & 1.100 & 1.342 & -- & -- & -- & -- \\
a) meninos & -- & 175 & -- & -- & -- & -- & -- & -- & -- \\
b) meninas & -- & 490 & -- & -- & -- & -- & -- & -- & -- \\
\hline Casamentos & 11 & 74 & 63 & 91 & 164 & 114 & 224 & 238 & 182 \\
\hline $\mathbf{1}^{a}$ comunhão & -- & 80 & 98 & 230 & 142 & 800 & -- & -- & -- \\
a) meninos & -- & 35 & -- & -- & -- & -- & -- & -- & -- \\
b) meninas & -- & 45 & -- & -- & -- & -- & -- & -- & -- \\
\hline
\end{tabular}

Antes de analisar os dados se faz necessário esclarecer que: a) os dados da tabela referem-se à igreja da Penha e demais igrejas de sua paróquia; b) que infelizmente os padres responsáveis pelas anotações não seguiam um padrão e muitos dados interessantes são anotados em um ano e no outro não; c) que os dados são referentes a todos os que freqüentavam a igreja da Penha e não somente aos moradores da paróquia; d) extremaunções, catecismo e primeiras comunhões são os dados mais próximos da realidade penhense do período analisado.

Os dados sobre batizados, comunhões e casamentos revelam-nos como a afluência à igreja cresceu ao longo do período. Entre 1904 e 1929, o número total de batizados na

${ }^{346}$. Cf. Livro Tombo da Freguesia de Nossa Senhora da Penha - Livro Códice 12-1-11, aberto em 1918, p.17.

347. Essa e as demais planilhas foram elaboradas a partir de pesquisa nas diversas páginas dos três Livros Tombo da Freguesia de Nossa Senhora da Penha.: Livro Códice 12-1-11, aberto em 1918, Livro Códice 12-1-12, também aberto em 1918; Livro Códice 8-3-12, aberto em 1933. 
igreja cresceu de 23 para 125, aproximadamente 443\%; o número de comunhões, entre 1919 e 1929, cresceu de 22.425 para 64.831, aproximadamente 189\%; já o número de casamentos, que também envolviam muitas pessoas que vinham de fora para receber as bênçãos da Santa penhense, entre 1904 e 1929, apresentou um crescimento astronômico, aproximadamente $1.554 \%$. Valores expressivos que demonstram a importância da Santa da Penha para São Paulo.

Os dados sobre catecismo em 1919 (490 meninas e 175 meninos) deixam claro que a mensagem religiosa chegava com muito mais eficácia à população feminina que à masculina. Certamente os meninos já estavam se dedicando a algum ofício e não tinham tempo de freqüentar as aulas religiosas.

Os dados de batismo são interessantes para a análise do crescimento populacional do bairro. Podemos observar que em 1919 esse número chegava a 468, em 1920 passou para 1.068 e em 1923 chegou ao valor de 1780, o que resulta, em quatro anos, num aumento considerável de aproximadamente 280\%. Acreditamos que esse crescimento corresponde ao estabelecimento de novos moradores na região.

Como vimos, a partir da década de 1920, as chácaras da região foram loteadas para a construção de moradias para famílias de operários, de funcionários públicos e outros trabalhadores que desenvolviam suas atividades em bairros como o Brás, a Mooca, o Belém, o Pari e no centro da cidade de São Paulo.

A Igreja rapidamente se organizou para tentar atrair essas famílias. Foi criada mais uma associação, a Liga Operária, que tinha por finalidade estabelecer vínculos destes novos moradores com a religiosidade local. Assim, já em 1920, “[...] dia 25 de janeiro às 7 horas da noite houve no salão São Geraldo reunião do Centro Operário afim de se tratar de assuntos de alta importância [...] todos que se interessavam pelo (centro) operário foram convidados a tomar parte nessa reunião.”348

O crescimento da população penhense estava diretamente relacionado ao crescimento das industriais paulistanas e era óbvio que os mais novos moradores eram de operários, portanto pessoas de poder aquisitivo baixo. Como veremos, a Igreja se preocupava com essa população porque nela residia o elo mais fraco da manutenção do catolicismo; devido à pobreza essas famílias estavam mais suscetíveis a novas ideologias e religiões. Coisa que comprometia a hegemonia da Igreja.

${ }^{348}$. Cf. Livro Tombo da Freguesia de Nossa Senhora da Penha. - Livro Códice 12-1-11, aberto em 1918, p.10. 
Com a aceleração do ritmo de vida proporcionado pelo processo de industrialização, a vida no subúrbio da Penha ganha conteúdo muito diferente daquele do bairro rural. O canto do galo e os toques dos sinos, representantes dos tempos lentos, começam a ceder lugar aos apitos dos trens e das fábricas. O tempo do trabalho começa a afetar o tempo livre, ou melhor, o tempo da reza, aquele que se utilizava para ir à igreja. O tempo do trabalho começa a consumir o antigo tempo da vida de bairro. ${ }^{349}$

Novos interesses econômicos, novos moradores, novas formas de se pensar o espaço contribuíam ainda mais para a decadência da Igreja. O clero percebeu que apenas a igreja matriz não era suficiente para atender as necessidades da população que crescia. Assim, dentro do novo cemitério da região foi inaugurada em 1919 um novo espaço de rezas, a capela de Santa Cruz. ${ }^{350}$ A luta pela hegemonia ainda estava no começo.

A falta de dinheiro, o afastamento do Estado, o enfraquecimento da hegemonia e a chegada de novos moradores acabaram por desencadear novas formas de se conceber os espaços da Penha. O templo e os espaços considerados pios não conseguiam resguardar o simbolismo de outrora e o que era sagrado torna-se suscetível à mundanidade. Por exemplo, em 1924, “[...] 29 de Setembro pegou-se um ladrão roubando a coroa da Santa, foi preso e condenado"351, e ,no mesmo ano, a prefeitura interditou o templo devido à situação degradante em que se encontrava, a alvenaria de barro da torre e das paredes tinha sido seriamente abalada por um tremor de terra. Tal fato causou indignação da população local que acreditava que o problema era mais por culpa da falta de manutenção do que do tremor propriamente dito. O problema se arrastou e o clero novamente caiu em desgraça com a população: “[...] tem proporcionado motivo de queixas e críticas da parte do povo contra o pobre vigário.”352 e “[...] não é raro ouvir que os padres só querem o dinheiro da Nossa Senhora e pouco cuidam dos interesses do povo e da religião.”353

${ }^{349}$. SEABRA O. L. C., op. cit., 2003, p.254.

${ }^{350}$. Cf. Livro Tombo da Freguesia de Nossa Senhora da Penha. - Livro Códice 12-1-11, aberto em 1918, p.21.

${ }^{351}$. Ibidem, p.16-v.

352 . Ibidem, p.19.

${ }^{353}$. Idem. 


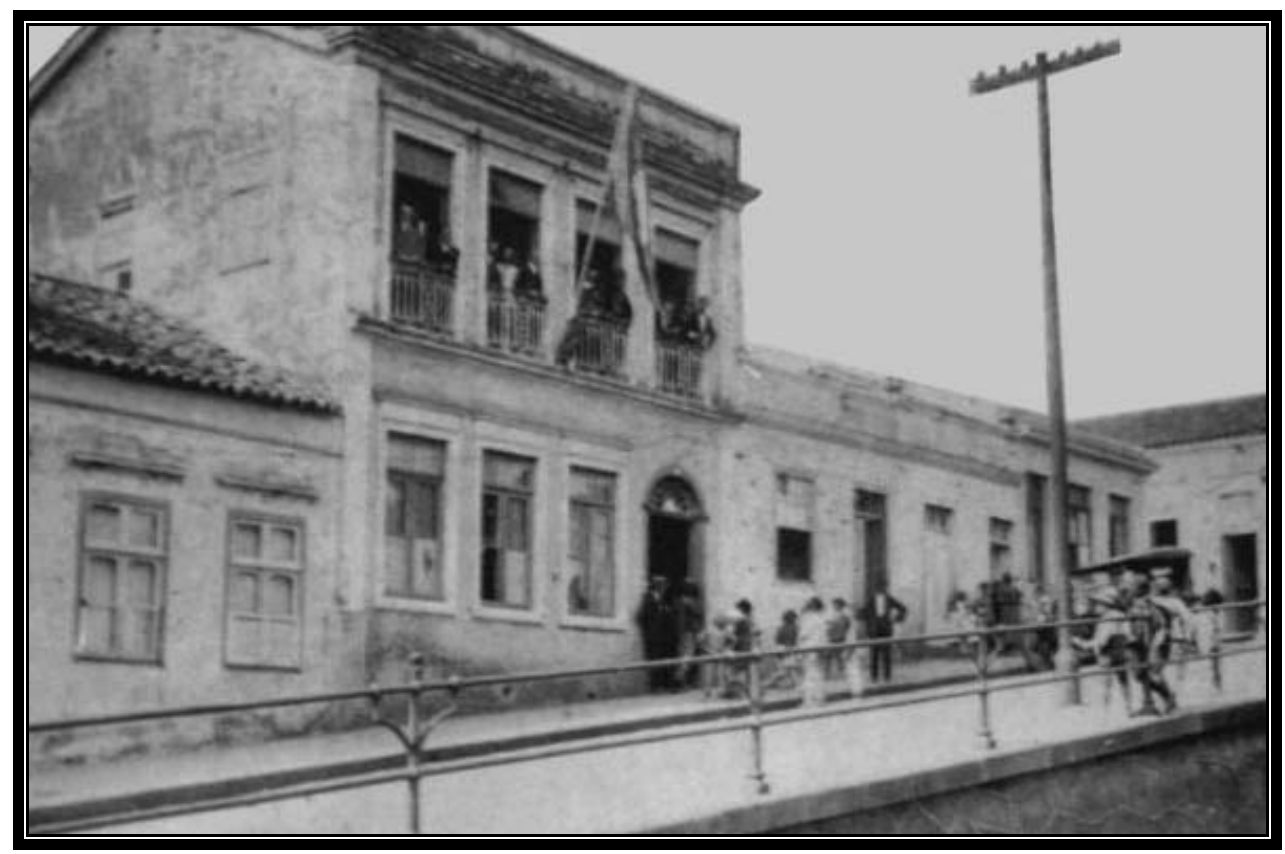

Posto policial no Largo do Rosário em 1924.

(Memorial da Penha de França, acervo digitalizado)

Segundo Seabra, críticas como essas revelavam que a prática social apresentava novos questionamentos à moralidade estabelecida pelas continuidades históricas abrigadas no interior do núcleo da Igreja. Tais questionamentos vinham com os novos moradores, que sendo imigrantes ou não, apresentavam novas concepções em relação aos valores cristãos até então estabelecidos. ${ }^{354}$

Em meio à crescente industrialização e a definição de um novo ritmo para a vida, os valores cristãos se perdiam e a família, que até os dias atuais a Igreja defende com veemência como esteio da manutenção desses valores, se viu engolida pelo furacão do mundo do trabalho. Para Seabra,

[...] com a industrialização, a vida correria tendo, de um lado a Igreja e a família, de outro a fábrica e a cidade em meio a terríveis contradições que se alimentavam mutuamente: para ser cidadão há que se integrar ao mundo do trabalho, mas para ser homem de bem há que se constituir família em conformidade com os preceitos da Igreja. ${ }^{355}$

Segundo Seabra, neste processo a Igreja acabou por eleger a mulher como a possibilidade de resguardo desses valores, já que os homens, cada vez mais envolvidos pelo mundo do trabalho, pouco se viam na condição de freqüentar a Igreja e muito menos levar a mensagem da mesma para os filhos.

\footnotetext{
${ }^{354}$. SEABRA O. L. C., op. cit., 2003, p.259.

${ }^{355}$. Ibidem, p 260.
} 
Assim, o fortalecimento e a criação das ligas e associações de mulheres católicas, enquanto estratégias de reprodução ideológica (Romanização) se reafirmaram e abarcaram a possibilidade de manutenção dos valores e da hegemonia católica penhense.

Essas ligas e associações diversificavam suas estratégias na ação de conquistar os novos moradores e seus familiares. Nessa ação, além da prestação de serviços (creche, cuidado de enfermos, alimentação de carentes etc.), a possibilidade da diversão sadia como atrativo para as missas tornaram-se mecanismos interessantes. Desta forma, o lazer (música, teatro, biblioteca, cinema e até fogos de artifício) após a missa tornou-se excelente recurso para aumentar a freqüência à igreja.

A estratégia era simples, a possibilidade de lazer atraía aqueles que não tinham o hábito de vir até igreja, certamente os pais de família; uma vez que esses apareciam seus familiares vinham juntos, o resto era com o sermão do padre e sua retórica em prol do convencimento da necessidade de se estabelecer o compromisso com a religião, com a caridade, com a cumplicidade e educação dos mais jovens. Assim, na missa o padre dava o pão e depois, as ligas davam o circo, e a Igreja garantia a reprodução de seus ideais.

Para exemplificar, entre tantos outros registros encontrados nos Livros Tombo, citaremos quatro que nos atraíram a atenção: o primeiro é de 1919, “com o fim de patrocinar ao povo da Penha algum divertimento inocente e ao mesmo tempo, de conseguir os meios necessários para a manutenção da associação dos moços que gostam de boa biblioteca e de jogos inocentes etc.” e a inauguração no Salão São Geraldo de "um cinema que funcionará todos os domingos e dia de feriados, sendo as fitas examinadas conscienciosamente. As primeiras exibições tiveram o mais completo êxito" 356 ; o segundo data de 17 de outubro de 1920, após a missa das seis, os sócios do C. Católico apresentaram no salão São Geraldo uma "solene secção dramático-musical”357 que fez grande sucesso e contribuiu para a presença de grande número de famílias; o terceiro data de 26 de agosto de 1921 durante novena para a Santa da Penha, com orquestra que "funcionou durante toda a novena" ${ }^{358}$; o quarto de 04 de setembro de 1921, quando realizou-se a festa de Nossa Senhora da Penha e uma

[...] multidão enorme derramava-se pelas ruas da Penha. Nenhum desastre ou desordem a lamentar. O policiamento como de todos os anos nulo. A igreja esteve repleta. A procissão à tarde movia-se com dificuldade por entre a multidão. Houve muito respeito. No tríduo final houve cinema ao ar livre e fogos. ${ }^{359}$

${ }^{356}$. Cf. Livro Tombo da Freguesia de Nossa Senhora da Penha - Livro Códice 12-1-11, aberto em 1918, p.12.

${ }^{357}$. Ibidem, p.14.

${ }^{358}$. Ibidem, p.15-v.

${ }^{359}$. Idem. 
O lúdico sempre fez parte das festas católicas. Assim, encenar passagens da bíblia, entoar cantorias, ter orquestras e fanfarras proporcionando musica ambiente e até apelar para shows pirotécnicos se justificavam enquanto emissores da palavra religiosa.

Com relação ao cinema, cabem algumas considerações. Segundo Seabra, junto com o rádio e a imprensa, o cinema fora em principio objeto de recusa da Igreja. Seabra, ao analisar esse fenômeno no Bairro do Limão, afirma que essas novas tecnologias representavam uma ameaça aos bons costumes cristãos, pois poderiam significar novas formas de uso para o tempo. Desta forma, essas novas tecnologias confrontavam com o tempo do sino e da missa, tão bem ritualizados pela Igreja. Segundo Seabra, “isso confrontava essencialmente o monopólio que a Igreja tivera, durante séculos, de ritualizar a vida."360

Tecnologia como o cinema, sem qualquer sombra de dúvida, era uma ameaça ao tempo da Igreja, afinal, o pouco tempo do não-trabalho que os moradores penhenses tinham deveria ser gasto na prática religiosa. Ainda mais que as sessões de cinemas particulares deveriam acontecer no mesmo horário que a missa como podemos ver na próxima citação. Se a Igreja quisesse manter sua hegemonia teria que se adaptar às novas possibilidades de uso do tempo do trabalhador.

A exibição dos filmes do Círculo Católico da Penha é o exemplo para o parágrafo acima, pois já havia um cinema na localidade, o Cine Penha. ${ }^{361} \mathrm{O}$ cinema da igreja abriu concorrência direta com o Cine Penha e o resultado não poderia ser outro senão o conflito:

Em três de abril [de 1921] realizou-se o Cinema do Círculo Católico, que desde janeiro esteve fechado em parte por causa da chuva. Houve nesse ínterim um trabalho meio oculto contra o Cine do Círculo por parte de alguns inimigos gratuitos. Queriam-no ver de portas cerradas em proveito do Cine Penha que mais uma vez se vira na contingência de fechar suas portas por se ver preterido pela população penhense que dava suas preferências ao Cinema do Círculo. Esses trabalhinhos deshonestos de denuncias junto a prefeitura de nada valem. $\mathrm{O}$ cinema do Círculo reabriu-se com licença das autoridades competentes e continuação de isempção de impostos e o seu rival não teve remédio sinão abrir uma sepultura ou antes enterrar na mesma cova que abrira para seu concorrente. Em todo esse negócio muitíssimo ficou devendo ao Círculo Católico, e com ele a paróquia, a exma sra Carolina de Souza Queiroz. ${ }^{362}$

Na verdade, a Igreja apenas começava a se dobrar às mudanças decorrentes da modernização social que começava a chegar à cidade. Segundo Seabra, evitar as novas

\footnotetext{
${ }^{360}$. SEABRA O. L. C., op. cit., 2003, p.265.

${ }^{361}$. Cf. Livro Tombo da Freguesia de Nossa Senhora da Penha - Livro Códice 12-1-11, aberto em 1918, p.15-v. Na bibliografia sobre história do Bairro consta a inauguração do Cine Penha no ano de 1926. No entanto, pelos detalhes das informações encontradas neste passamos a acreditar que o Cine Penha ${ }^{362}$. Idem. teve uma segunda inauguração no ano de 1921.
} 
tecnologias de certa forma se apresentava como "um comportamento descompassado"363, pois, apesar do cinema representar mais uma das ameaças ao sentimento religioso e ser encarado até como algo profano, “a Igreja já havia descoberto que não havia como enfrentar a nova arte, o novo discurso, a nova imagem." 364

Segundo Seabra, “em torno de São Paulo, no núcleo dos velhos bairros, Igreja e cinema andaram juntos”, afinal com a urbanização “contingentes cada vez mais expressivos de migrantes, criava a oportunidade de novas relações e os dispunha a novas experiências. Foi de tal natureza que as paróquias foram estimuladas a instalar suas salas de cinema, geralmente conhecidas por 'cinema do padre’.,365
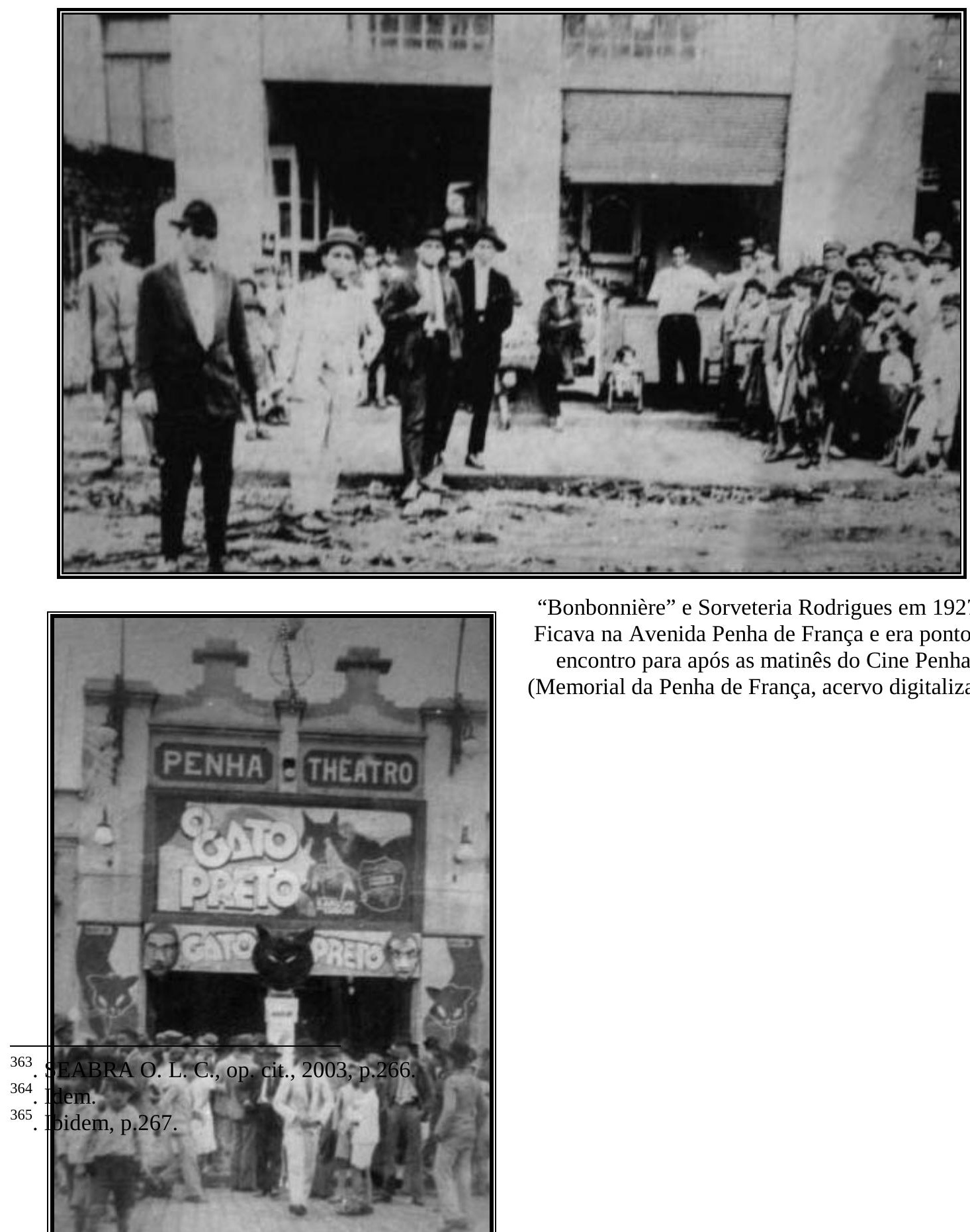

“Bonbonnière” e Sorveteria Rodrigues em 1927 Ficava na Avenida Penha de França e era ponto de encontro para após as matinês do Cine Penha. (Memorial da Penha de França, acervo digitalizado) 
Cine Theatro Penha em 1927.

(Memorial da Penha de França, acervo digitalizado)

Voltando à questão do espaço penhense, na década de 1920, o controle da Igreja sobre o mesmo já era bastante frágil. O templo perdia-se diante dos interesses públicos e os espaços pios tornavam-se cada vez mais restritos na Penha. Como reflexo do conjunto de leis que regulamentavam o uso da terra no Brasil desde a Proclamação da República, a divisão entre o público e sacro, entre sacro e privado e entre privado e público se apresentava bem definida e sem a mínima dúvida, o espaço sacro, tanto físico quanto simbólico, tinha sofrido as maiores perdas.

O estabelecimento dessas fronteiras, físicas e/ou ideológicas, como fruto de imposição dos novos valores estabelecidos pelas necessidades do desenvolvimento urbano não consistia apenas em atenuação do sagrado diante do profano. A expropriação do espaço sagrado era apenas mais um reflexo da imposição das limitações impostas pelo mundo da mercadoria.

Assim, se no espaço físico a Igreja perdia sua influência, sua luta pela manutenção dessa influência continuava com muito fôlego. A criação das escolas paroquiais de ensino básico e religioso apresenta-se como exemplo desse embate.

Novamente a Igreja encontrava dentro dos processos modernizadores, no caso a escola regular, a possibilidade de manter sua hegemonia.

Os primeiros registros encontrados sobre a organização da instrução pública na Penha datam de 1845, quando o Padre Antonio Benedito de Camargo foi nomeado professor público com gratificação anual de 200 mil reis. Depois, em 22 de outubro de 1852, foi nomeado Celestino José de Oliveira. E em 21 de março de 1864, foi nomeada D. Paulina Francisca de Alvarenga. As aulas eram dadas no lar das vicentinas, atual Colégio São Vicente de Paula ${ }^{366}$ e recebiam o nome de escolas paroquiais.

O primeiro estabelecimento de ensino oficial da Penha foi inaugurado na Praça Oito de Setembro em 1913 e recebeu o nome de Grupo Escolar da Penha (atual Escola Santos Dumont). ${ }^{367}$

366 . EGYDIO MARTINS, A., op. cit., 2003, p.447.

${ }^{367}$. SANTARCANGELO, M. C. V., op. cit., 1968, p.25. 
Já na Penha de 1924, sobre orientação do Padre Antão Jorge funcionavam oito escolas paroquiais (São Vicente, Sant’ana, Vila Concórdia, Ponte Grande, Guaiaúna, Vila Esperança, São Pedro e Maranhão) com oitocentos alunos matriculados, entre crianças e adultos, conforme podemos observar no quadro abaixo. ${ }^{368}$

\begin{tabular}{ccc}
\hline ESCOLAS PAROQUIAIS & PERÍODO & $\mathbf{N}^{0}$. DE ALUNOS \\
\hline São Vicente & Diurno & 335 \\
\hline \multirow{2}{*}{ Sant'Ana } & Diurno & 170 \\
& Noturno & 115 \\
\hline Vila Concórdia & Diurno & 20 \\
\hline Ponte Grande & Diurno & 73 \\
\hline Guaiaúna & Diurno & 76 \\
\hline Vila Esperança & Diurno & 48 \\
\hline São Pedro & Diurno & 8 \\
\hline Maranhão & Diurno & 35 \\
\hline & TOTAL & $\mathbf{8 0 0}$ \\
\hline
\end{tabular}

A Igreja católica, na figura do Padre Antão, assumiu a responsabilidade pela instrução da população local. Nem precisamos reafirmar aqui qual a importância do ensino religioso nestas escolas.

O catolicismo se esforçava em participar da vida do penhense e tudo acontecia com o apoio cada vez maior das associações e ligas. Eram os membros destas que organizavam as escolas paroquiais. As ligas e associações eram os braços da Igreja penhense.

Como estratégia redentorista, por meio das associações e da prestação de serviços, a Igreja conseguia se aproximar da população, reforçar suas posições, fortalecer seus vínculos com as elites e se reaproximar dos políticos que comandavam o Estado. Assim, no adro da capela, no ano de 1926, depois da missa, houve comício e discurso de Washington Luiz, então candidato a presidente do Brasil. ${ }^{369}$

Em 1926, o curso noturno foi ampliado nas escolas paroquiais da Vila Esperança e da Guaiaúna e a quantidade de alunos neste período passou para 891. Estes cursos noturnos eram direcionados aos trabalhadores, principalmente operários da região.

${ }^{368}$. Cf. Livro Tombo da Freguesia de Nossa Senhora da Penha - Livro Códice 12-1-11, aberto em 1918, s/p.

${ }^{369}$. Idem, s/p. 


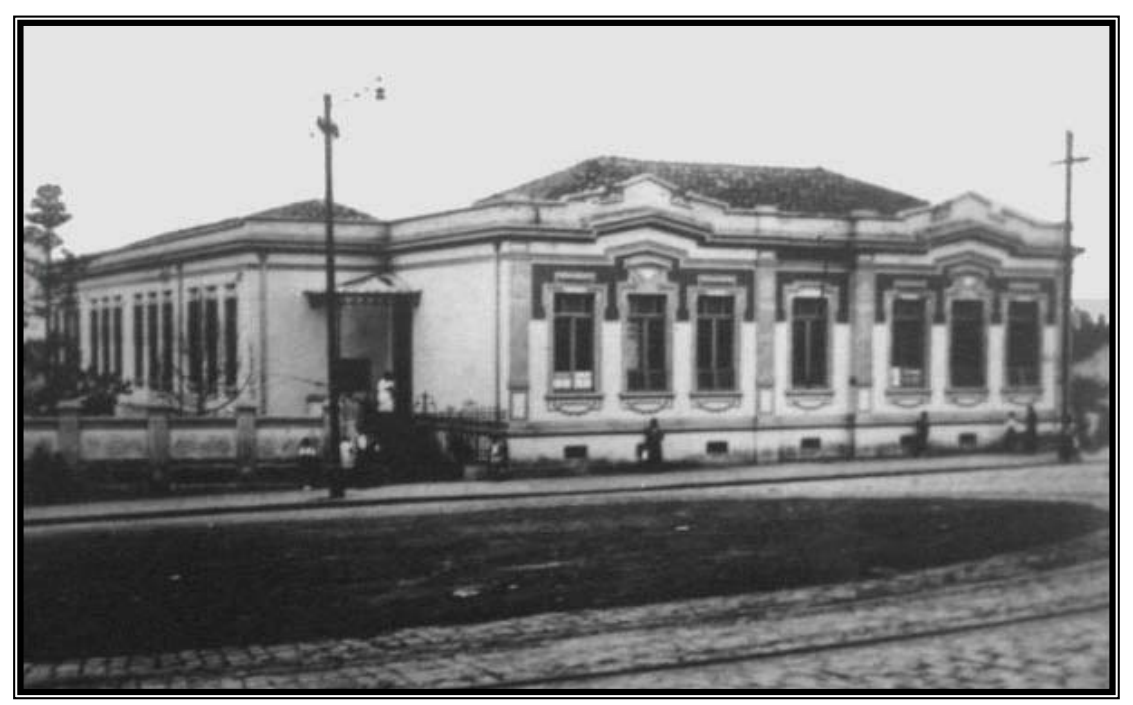

Grupo Escolar da Penha em 1935 - Atual Escola Santos Dumont. (Memorial da Penha de França, acervo digitalizado)

A Igreja considerava essas escolas paroquiais como escolas mistas (laicoreligiosas) e justificava-as com os seguintes argumentos: “[...] avaliando quanto custaria ao governo a instalação de quase 900 crianças e ainda ponderando que todas recebem instrução sólida na região, facilmente se compreende a importância das escolas paroquiais[...]" e lamentava-se que "[...] o ensino religioso administrado semanalmente nas capelas e Igrejas é infelizmente insuficiente em virtude da inconstância e dissipação das crianças pela impossibilidade de obrigá-las a um estudo sério o do Catecismo, a única solução na situação atual são colégios católicos e escolas paroquiais.”370

Podemos observar que as funções de Estado que a Igreja teimava em realizar ainda se mantinham. Afinal, nos subúrbios o descaso do governo pela educação era grande. Poucos eram os chamados grupos escolares e a Igreja, de forma pensada, tomava para si tal função social.

Nas escolas paroquiais, as mulheres das associações assumiam o ministrar das aulas.

No propósito 'educar', o reforço da ideologia ficava no mesmo patamar que a alfabetização. Só para ilustrar, em 1925, eram encontradas oito importantes associações agindo na paróquia com uma considerável soma de associados - 1831 ao todo. Um verdadeiro exército em defesa do catolicismo. Conforme registros encontrados nos Livros Tombo em $1925^{371}$ :

\begin{tabular}{cc}
\hline ASSOCIAÇÕES CATÓLICAS & SÓCIOS \\
\hline Liga Católica & 336 \\
\hline Conf. de São Vicente & 45 \\
\hline União dos Moços Católicos & 50 \\
\hline
\end{tabular}

\footnotetext{
${ }^{370}$. Ibidem, s/p.
}

${ }^{371}$. Idem, s/p. 


\begin{tabular}{cc}
\hline Apostolado de Orações & 713 \\
\hline Core de São José & 335 \\
\hline Filhas de Maria & 160 \\
\hline Liga do Menino Jesus & 182 \\
\hline Damas de Caridade & 10 \\
\hline TOTAL & $\mathbf{1 8 3 1}$ \\
\hline
\end{tabular}

O aumento da população, a expansão das áreas residenciais, as distâncias e as dificuldades de deslocamento da população da região obrigaram a Igreja penhense a descentralização ainda mais as suas atividades. Assim, a partir de 1924, novas capelas foram erguidas: Santo Antônio (Vila Ponte Grande); São José (Vila Maranhão) e Santa Ana (Vila Maranhão). Em 1928 surgiram ainda, em terrenos doados, as capelas da Vila Matilde e Vila Esperança.

No primeiro quartel do século vinte, cabia à paróquia de Nossa Senhora da Penha de França o controle e administração de uma extensa região que compreendia a Penha, São Miguel, Itaquera, Lageado (Guaianazes), Poá, Arujá e Itaquaquecetuba. Pelas distâncias e as dificuldades de deslocamento constante de padres, o controle territorial era inviável e não atendia as necessidades do número de almas que aumentavam rapidamente na região.

Para facilitar esse controle, as capelas paróquia que se encontravam mais distantes receberam sua emancipação. No ano de 1928, em “[...] 12 de Dezembro foi fundada a nova paróquia de Itaquera e para este fim foi desmembrada da paróquia da Penha mais ou menos a metade de seu território [...] por causa de sua distância da matriz só dificilmente podia chegar a ela [...] $]^{372} \mathrm{E}$ aos poucos, até as mais próximas, receberam o direito de ter seu próprio vigário. Assim, em 1930, outro desmembramento importante: a recém inaugurada capela de Vila Esperança nem bem fora inaugurada e já se transformou em paróquia.

Desmembrar requeria definição de território e de fronteiras, para que cada ministério desenvolvesse suas próprias estratégias de acolhimento, de conquista de fiéis e de arrecadação. Desta forma, em “[...] 8 de Março foi separada da Penha e eregida em paróquia a Vila Esperança.” 373

Na região da Penha, a ereção das novas capelas estava diretamente associada ao aparecimento dos novos loteamentos. Assim que esses recebiam seus primeiros moradores uma capela se estruturava e virava referência ideológica e geográfica. O

\footnotetext{
${ }^{372}$. Idem, s/p.

373. Cf. Livro Tombo da Freguesia de Nossa Senhora da Penha - Livro Códice 12-1-11, aberto em 1918, p.41.
} 
aumento da população do loteamento e da arrecadação definia a sobrevivência e o status da nova capela e caso essa se mostrasse auto-suficiente, poderia requerer ou receber sua autonomia e tornar-se paróquia.

Não podemos esquecer que a maioria dos moradores desses loteamentos era composta por operários e seus familiares que pouco tinham a oferecer para a igreja. Essa carência de recursos geralmente comprometia a sobrevivência dessas novas paróquias e caso as mesmas não conseguissem arrecadar o suficiente para sua própria subsistência, cabia à paróquia mais próxima mantê-la funcionando.

Com a Revolução de 1930, a situação econômica e social dos moradores da região se agravou ainda mais. Segundo anotação em Livro Tombo, a situação tornava-se insustentável para a sobrevivência das paróquias: “[...] crise que atravessamos, nota-se muito pela escassez das esmolas que entram no Santuário da Penha.”374 E se na paróquia de Nossa Senhora da Penha, a mais rica da região, a escassez de esmolas era um problema, podemos imaginar o que acontecia nas paróquias recém criadas. Volta e meia, essas novas paróquias voltavam ao comando da antiga Matriz, conforme podemos observar na transcrição de 1930, “[...] no mês de Junho anexou a paróquia de São Miguel à da Penha [...]”375 Uma vez que melhoravam em arrecadação, elas voltavam a se emancipar.

As ereções de novas capelas e as criações de novas paróquias faziam parte das estratégias de manutenção da hegemonia territorial do catolicismo no combate contra as novas doutrinas religiosas (protestantes e espíritas) e às novas concepções políticas (comunistas e anarquistas) que se espalhavam pela cidade. Essas novidades eram trazidas pelos imigrantes europeus e se espalhavam rapidamente, sobretudo entre os mais pobres.

Para a Igreja, essas novas concepções nada mais eram que a pregação da desordem e o rompimento com Deus e cabia aos trabalhadores penhenses compreender que a melhor forma de se exigir melhores salários e demais direitos trabalhistas era a subserviência. Segundo a publicação O Mensageiro de Nossa Senhora da Penha de 1929:

\footnotetext{
Os que querem levar os operários a abandonarem a religião e a insurgirem contra a ordem social, sempre são inimigos da Egreja porque sabem que nunca será elemento revolucionário o operário que se conservar fiel a Deus e à Egreja. Entretanto, nunca conseguira melhorar as condições dos operários os agitadores que os incitarem à violência e à revolta: são exploradores que na hora do perigo se escondem e deixam os pobres operários em condições mas tristes que antes. Os

374. Ibidem, p.41-v.

${ }^{375}$. Idem. Estando esta localidade ainda distante do desenvolvimento urbano paulistano, sofria com a pouca freqüência de fiéis e com a dificuldade de arrecadar, somente a partir de 1937 com a instalação da Cia. Nitro Química S.A. a paróquia conseguiu se firmar.
} 
operários que seguem o caminho da religião, sabem levar uma vida regulada e de cumprimento fiel de seos deveres, sabem defender seos direitos e interesses sem violência, sabem tornar-se dignos de estima e confiança de seos chefes: sabem, enfim, ganhar alem da paz de uma consciência tranqüila, verdadeiro contentamento e bem estar em sua própria condição de operariado.”

A transcrição não deixa dúvidas quanto aos motivos que levaram o operariado a se afastar da Igreja. Tal discurso acabava dando à Igreja Católica penhense uma conotação de Igreja dos patrões, dos ricos e dos poderosos, assim, muitos dos operários passaram a demonstrar suas insatisfações se refugiando em outras ideologias e posturas políticas. Nelas, esse operariado se fortalecia na luta diária contra o que os oprimia.

Importante lembrar que, se nos loteamentos se estabeleciam as populações mais pobres, no topo da colina ficavam os moradores das famílias de mais recursos, alguns morando em casarões luxuosos e tendo carros modernos na garagem. Além dos Rodovalho, havia os Vergueiro, os Paiva Azevedo, os Gomes Jardim, os Augusto Camargo, entre outros.

Esses desfilavam pelas ruas da Penha com suas vestimentas e seus chapéus caros, seus automóveis novos, eram bem articulados com os políticos paulistanos, praticavam esportes, ocupavam os melhores bancos da igreja. Era parte da sociedade penhense bem articulada com os modismos das classes mais abastadas da cidade de São Paulo dos anos trinta.

Mas essa era a minoria da Penha, casarões e ostentações se apresentando em grande contraste com a pobreza que rodeava o topo da colina. Até os anos trinta, ainda predominava uma população carente, vivendo em residências simples, à beira de estradas de terra poeirentas no inverno e lamacentas no verão, casas de taipa de chão pisado, sem eletricidade, com água de poço entre plantações e animais domésticos soltos. Como podemos observar nas fotos que se seguem.

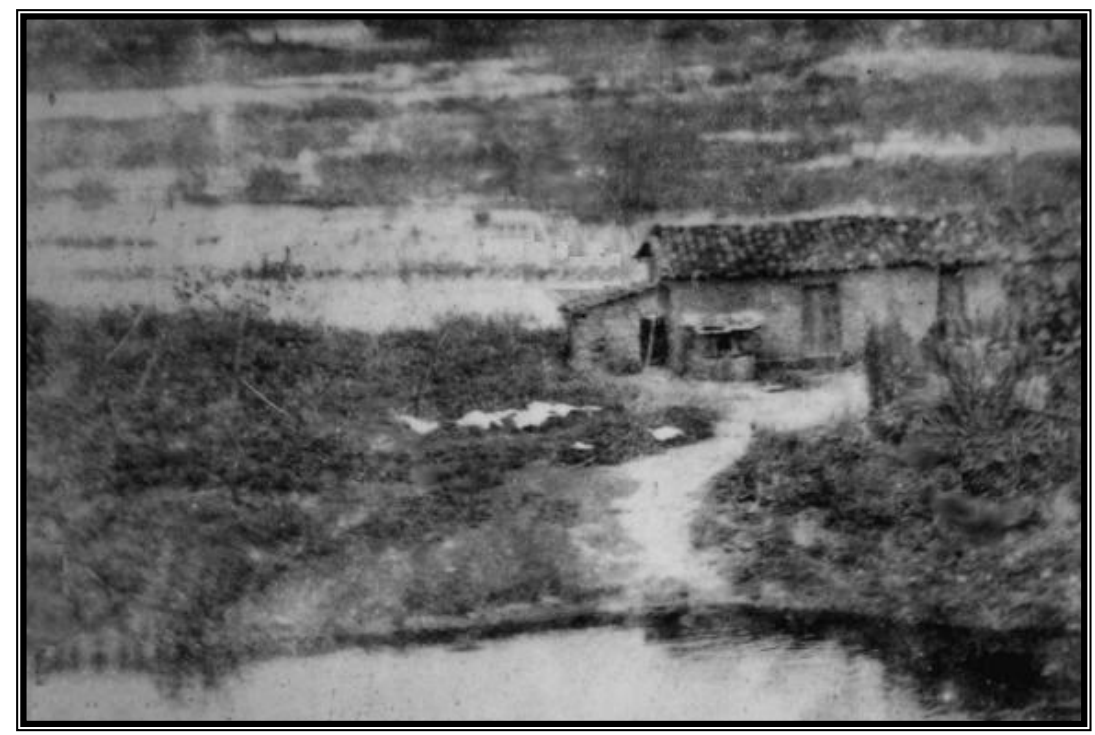

Casa de Micaela Vieira em 1933, localizada às margens do rio Tietê, "Tia Micaela” era uma famosa parteira da Penha. (Memorial da Penha de França, acervo digitalizado) 


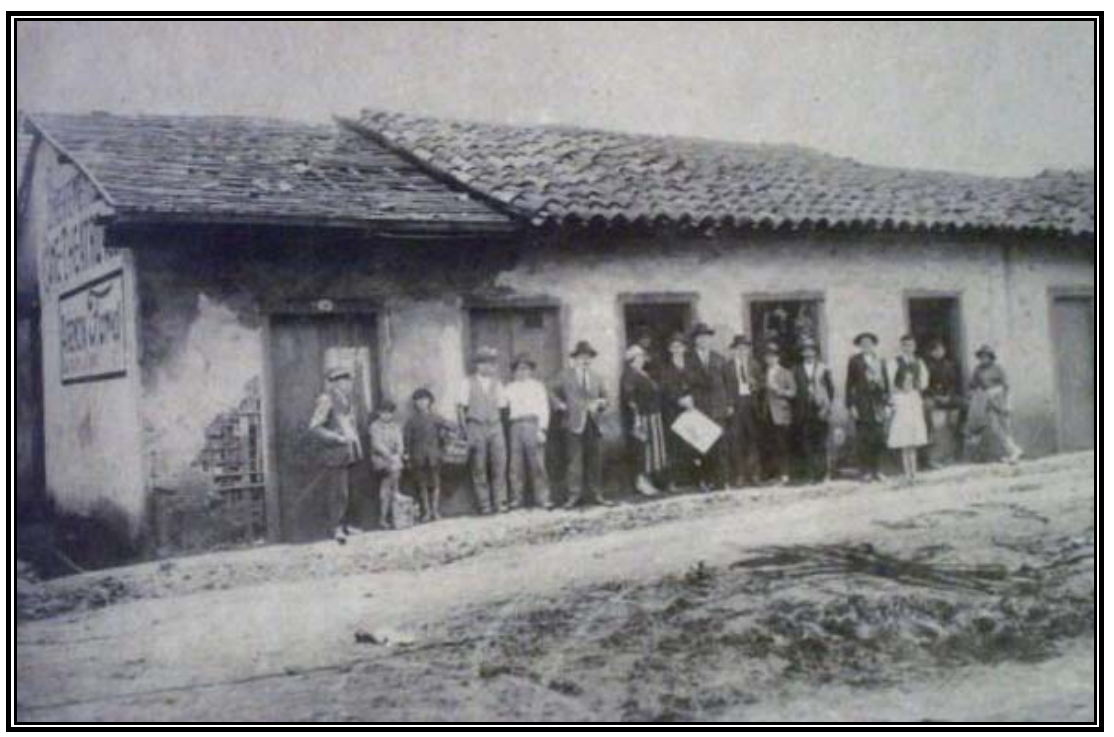

Exemplo de casa de pau-a-pique encontrada no bairro da Penha - Esta foto é da Avenida Penha de França em 1925 e no lugar destas construções foi construído o Cine Penha. (Memorial da Penha de França, acervo digitalizado)

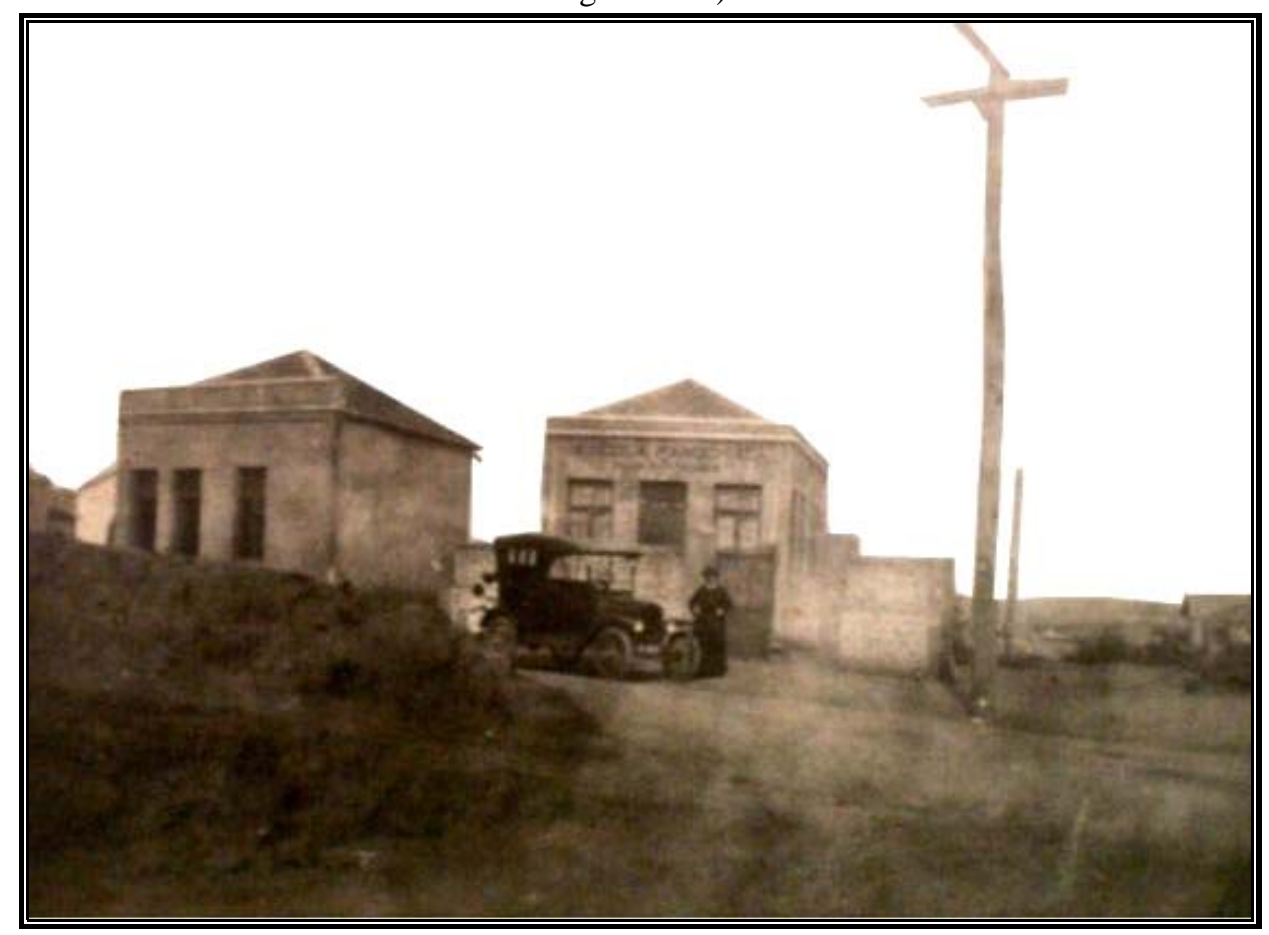

Casa paroquial em 1923 - Também utilizada como escola paroquial, localizava-se na estrada para o Rio de Janeiro, mais precisamente na Vila Esperança, no cruzamento das atuais Avenidas São Miguel e Avenida Amador Bueno da Veiga. (Memorial da Penha de França, acervo digitalizado)

As fotos revelam as condições de vida da maior parte dos penhenses. Permitem observar que o rural ainda estava muito presente no subúrbio da Penha.

Infelizmente não encontramos fotos dos loteamentos.

Voltando à questão das novas concepções religiosas, podemos observar que os mais pobres iam de uma religião à outra com muita facilidade e muitas vezes a 
necessidade material se confundia com as necessidades espirituais. Bastava que qualquer uma dessas religiões acenasse com a possibilidade de doações (alimentos, remédios, roupas usadas, material de construção, material escolar, atendimento médico ou dentário) e pronto, faltava cadeira para o culto.

Na Penha da década de 1930, encontramos vários exemplos que mostram a preocupação que a Igreja tinha com o aumento das novas doutrinas entre as populações mais carentes do bairro:

[...] abriu-se no dia 16 de outubro mais uma escola paroquial no salão São Geraldo, especialmente destinada às criancinhas da Rua Guaiaúna para neutralizar os efeitos malignos do 'Exército da Salvação' [...] abriram-se desde o mês de Julho os seguintes centros catequistas: [...] o Centro do Rosário, na Igreja do Rosário; o Centro de São Geraldo no salão São Geraldo; o Centro de Santa Cruz; na capela de Santa Cruz; o Centro Escola de Da Alice, perto de Sant’Ana; o Centro de São João Batista, na capela de São João Batista, Jardim Concórdia; o Centro de Cangaíba, perto da nova linha da EF.CB; acrescentando-se o Centro de São Miguel, os três Centros de Poa, Itaqua e Aruja com o Centro no ginásio Sr. Benardino de Campos; juntos os Centros já existentes, chega-se ao número de 23 Centros de Catecismos com mais de que duas mil e trezentas (2.300) crianças [...] faltando ainda umas mil crianças. Trabalha-se agora para trazer ainda estas crianças todas ao catecismo [...] $]^{376}$ [Continuando] [...] numa reunião conjunta das diretorias de todas as associações religiosas procedeu-se a um exame minucioso da situação religiosa da paróquia. Existem no território da paróquia da Penha uma casa do ‘Exercito da Salvação' com uma filial perto da Vila Sant’Ana - 3 casas de 'sessões espiritas' - um Centro de 'Teosofismo' em Guaiaúna, 'uma casa de orações' em Vila Sant'Ana pertencente aos protesta (?), uma 'Escola 7’(?), 'Católicas Universais' na rua Francisco Coimbra n³0 - 'Sociedade Japonesa' com propaganda arreligiosa a qual chamam crianças, rua Antônio Lobo, 15 Tomou-se, nesta reunião, como resoluções a intensificação do catecismo paroquial com todos os meios ao alcance $[. . .]^{377}$

Outra medida: “[...] para combater melhor o protestantismo e especialmente a freqüência de tais 'casas de oração', do culto protestante, experimentou-se o exercício das novenas à Nossa Senhora da Aparecida em casas particulares (em frente a dos protestantes) com a nossa imagem de Nosso Senhor das Missões. Até agora foi de grande resultado. ${ }^{378}$ A Igreja procurava também combater “[...] a existência de casais unidos só civilmente $[\ldots]^{3,379}$.

Na cruzada contra as novas crenças, procura-se intensificar, principalmente entre os jovens, os ritos mais importantes do catolicismo oficial: as comunhões, os batismos e os casamentos, aqueles que fortaleciam a fé e que ressaltavam o imaginário de possível salvação, como podemos observar na tabela abaixo.

\footnotetext{
376 . Ibidem, p.42.

377. Ibidem, p.42v.

${ }^{378}$. Ibidem, p.46v.

${ }^{379}$. Ibidem, p.42v.
} 


\begin{tabular}{cccccccccccc}
\hline ANO & 1930 & 1931 & 1931 & 1933 & 1934 & 1935 & 1936 & 1937 & 1938 & 1939 & 1940 \\
\hline Comunhões & 60.150 & 66.751 & 76.320 & 74.947 & 70.467 & 88.386 & 77.738 & 74.870 & 58.513 & 123.150 & 124.290 \\
\hline Batizados & 4.440 & 4.583 & 4.245 & 4.683 & -- & 4.907 & 4.642 & 4.615 & 5.101 & 5.126 & 4.720 \\
\hline $\begin{array}{c}\text { Extrema- } \\
\text { unções }\end{array}$ & 146 & 123 & 105 & 84 & 115 & 97 & 142 & 167 & 121 & 139 & 121 \\
\hline Casamentos & 352 & 195 & 203 & 221 & 158 & 441 & -- & 224 & -- & 304 & 237 \\
\hline
\end{tabular}

O crescimento urbano e a penetração das novas formas de se conceber a sociedade trouxeram novos moldes às relações entre a Igreja e seu entorno e apesar dos vários trabalhos desenvolvidos pelas associações entre os mais carentes do bairro, o combate às novas ideologias, tanto religiosas como políticas, tornavam-se cada vez mais complicadas. A Igreja Católica não conseguia transpor o abismo estabelecido entre ela e o meio operário.

Para parcela do operariado, a Igreja Católica penhense era "vendida" e não poderia nunca representá-los. Segundo Bôa Nova,

[...] o catolicismo oficial tem penetração relativamente pequena entre a população que habita os bairros pobres das cidades [...] cria-se um vazio religioso que irá constituir campo fértil para a expansão de outras religiões [...] e não é para admirar que o rápido aumento do número de protestantes e espíritas $[. . .]^{380}$

A união estabelecida entre Igreja, políticos e lideres carismáticos (clientelistas e até populistas) apelava de todas as formas para tentar sustentar o tradicional sistema de dominação entre as classes mais pobres. No entanto, havia aqueles que o discurso não alcançava a que optavam pelo rompimento. ${ }^{381}$

Segundo Morse, os moradores das cidades que desistiam de se acomodar à dominação exercida pelo catolicismo e seus aliados passavam a se voltar para grupos ou movimentos (pentecostais, espíritas, umbandas) que lhes permitissem, pelo menos psicologicamente, separarem-se dela. ${ }^{382}$

Segundo Morse:

O seu atrativo se exerce especialmente em relação às classes inferiores e ocorre, de modo característico, nas zonas rurais em transição e nas grandes cidades, onde as mudanças afetam fortemente a estrutura tradicional da sociedade. De acordo com suas diversas peculiaridades, tais seitas subvertem simbólicamente a estrutura existente de poder, rejeitam o paternalismo das classes superiores e dão ao iniciado oportunidade para refazer suas relações comunitárias. O converso sente que é necessário e que desperta confiança, na qualidade de 'irmão', e se for dotado de 'podêres', adquire um reconhecimento de sua capacidade pessoal, que é negada pelo mundo exterior. ${ }^{383}$

Morse ainda afirma que o culto proporcionava "uma terapia eficiente para as angústias e os problemas da personalidade, visando também a uma reorganização

${ }^{380}$. BÔA NOVA, A. C. op. cit., p.115.

${ }^{381}$. MORSE, R. M., op. cit., 1970, p.397.

${ }^{382}$. Ibidem, p.397-398.

${ }^{383}$. Idem. 
radical da sociedade e dos hábitos pessoais dos conversos”384 e isso era mais que suficiente para que esses se organizassem em pequenos grupos assistencialistas que foram se espalhando pela cidade. Tais grupos se organizavam de tal forma que passaram do assistencialismo à mobilização política e atualmente representam importantes setores do eleitorado brasileiro. ${ }^{385}$

Na Penha, a luta do catolicismo pela contenção da ascendência destas novas tendências religiosas entre o operariado e seus familiares acirrou-se e, segundo Livro de Tombo;

[...] por ordem da autoridade Arquidiocesana houve diversas reuniões do Centro Metropolitano dos Operários Católicos (C.M.O.C.) que tem a sua sede no Brás. A $1^{\mathrm{a}}$ reunião foi desoladora, e a $2^{\mathrm{a}}$ um pouco mais animosa e a $3^{\mathrm{a}}$ na matriz do Parí suficiente para ouvir a exposição do Progresso e aplaudir o Delegado escolhido para representar o operariado católico junto ao Governo Provisório. É vontade do Ex.mo Snr Bispo Metropolitano de ser fundada uma 'filial' da CMOC em todas as paróquias. Começou-se a agitação da idéia nesta paróquia e o pensamento do vigário é o seguinte: Aproveitar-se dos (?) para escreve-los no CMOC, em todas as paróquias digo nomear 'delegado paroquial' que trate do assunto - fazer mensalmente uma reunião dos operários na Sala São Geraldo. Esta reunião no II Domingo, coincide com o domingo em que as crianças tem o seu cinema mensal e, portanto, tem-se fitas em seu poder. Oferecer-se-á aos operários e suas famílias uma ou duas horas de cinemas, espetáculos ou qualquer outra diversão gratuita e conferência sobre questões operárias. ${ }^{386}$

A Igreja deveria ser, a qualquer custo, o espaço onde a comunidade deveria se reunir.

A preocupação dos católicos da Penha ia além das ameaças resultantes das novas religiões, a política brasileira dos anos de 1930 passava por um período de grande turbulência. A grande depressão capitalista, a Revolução de 1930 e o aumento da miséria intensificaram os conflitos sociais e ideológicos, e facilitavam o crescimento dos ideais nazi-fascistas e de esquerda.

Diante deste quadro, observou-se certa tensão na Penha em 1931. Segundo o Padre Estevam Maria

[...] nas semanas passadas houve, na cidade bastante agitação e mesmo, por algumas horas, de caracter comunista. Aqui na Penha correu tudo em Paz e parece, não ter 'cela vermelha' nenhuma. Isto talvez deva-se à circunstância de terem a grande maioria de operários a sua pequena propriedade de um lote de terra com a sua casa, comprada com o suor de suas mãos, digo muitos anos de trabalho. Deverá atribuir-se também ao intensivo trabalho dos padres no meio dos homens: três ligas Católicas, Congregação Mariana e cinco Conferências Vicentinas. Sabemos que os homens entre sí formaram uma legião pela defesa do templo, prontos ao primeiro sinal combinado a socorrer e defender a Igreja, os

\footnotetext{
384 . Idem.

385 . Idem.

386. Cf. Livro Tombo da Freguesia de Nossa Senhora da Penha. - Livro Códice 12-1-11, aberto em 1918, p.43v.
} 
Padres e as Irmãos contra qualquer comunista. Pelo que estou informado qualquer defesa necessária não seria feita de luva de pelica $[\ldots]^{387}$

O catolicismo penhense começa a se desesperar e aprovar qualquer atitude contra a ameaça comunista.

E a luta pela hegemonia continuava na cúpula do catolicismo paulistano. Levantou-se até a hipótese de se obrigar o estabelecimento do ensino religioso em todas as escolas públicas da capital, porém não se obteve apoio do governo e a proposta naufragou.

Em 1932, segundo Livro de Tombo da Paróquia,

[...] no dia 9 de julho irrompeu um movimento revolucionário em São Paulo, para conseguir a imediata constitucionalização do País como dizem seus dirigentes. O arranco foi tremendo e fulminante. Da paróquia da Penha alistaram-se cerca de 800 voluntários. Os Padres mantiveram-se alheios ao movimento propriamente militar $[\ldots . .,]^{388}$

O movimento ia ao encontro dos interesses de políticos paulistanos ligados à Igreja.

No entanto, após a Revolução Constitucionalista, o país se preparava para as eleições e a Igreja penhense não se acanhou, tomou posição e passou a pedir votos abertamente aos políticos que lhe interessavam. Em 1933, o Padre Vigário Oscar Chagas Azeredo organizou e incentivou a Liga Eleitoral Católica, a LEC, para trabalhar como cabo eleitoral e apoiar candidatos que combatessem o socialismo e o 'anticlericalismo'389. Pelo que pudemos observar a Igreja não conseguiu eleger seus candidatos e segundo o Livro Tombo o envolvimento da Igreja Católica com a política não foi muito bem visto e só piorou a relação da Igreja com os moradores da Penha. O mesmo vigário escreveu que

[...] apesar dos esforços de toda a espécie foi difícil desfazer o preconceito popular contra a Liga Católica, além disso, na Penha trabalharam muito para o serviço do alistamento diversos partidos, que dispunham de muito dinheiro e de não pequeno prestígio, v. g. o Partido Republicano Paulista, o Partido Democrático, o Partido Socialista, protegido pelo interventor de São Paulo, o Partido Integralista e não sei mais quantos $[. . .]^{390}$

${ }^{387}$. Ibidem, p.46v e 47.

${ }^{388}$. Cf. Livro Tombo da Freguesia de Nossa Senhora da Penha. - Livro Códice 8-3-12, aberto em 1933, p.53.

389 . Infelizmente não foi possível identificar quais eram esses candidatos.

390. Cf. Livro Tombo da Freguesia de Nossa Senhora da Penha - Livro Códice 8-3-12, aberto em 1933, p.55v. 


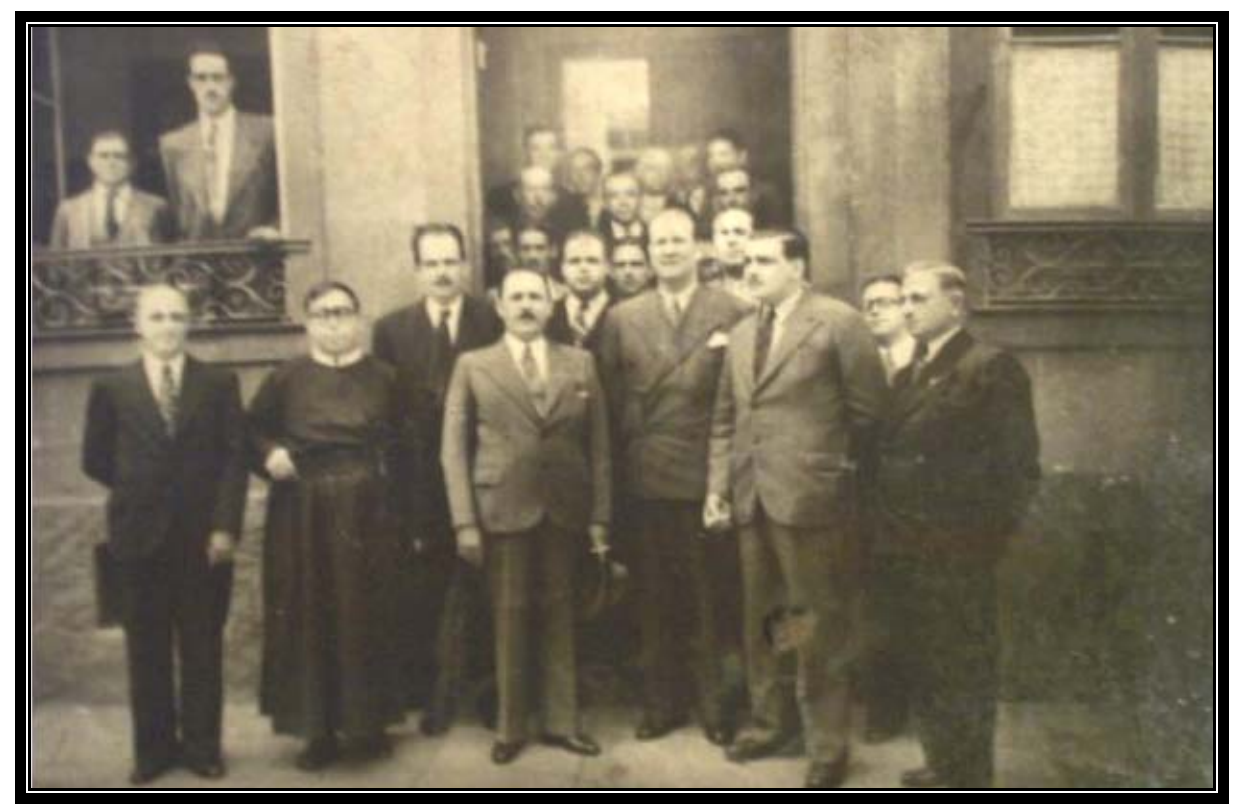

Inauguração do Partido Constitucionalista da Penha em 1935, junto ao prédio do Externato São Vicente Ao centro, segurando o chapéu está o prefeito de São Paulo Fábio Silva Prado e ao seu lado direito, o Vigário Oscar Chagas Azeredo. (Memorial da Penha de França, acervo digitalizado)

A ação política da Igreja penhense foi tão intensa, que chegou até a propor abertamente uma chapa única contra o socialismo e o anticlericalismo. Tal estratégia não emplacou, o avanço do socialismo em meio ao operariado ampliara-se e os choques entre os partidários da Igreja e seus desafetos tornaram-se mais intensos. Em junho de 1933,

[...] chegou a triste notícia de que os comunistas do bairro de Cangaíba, capela filial de São Miguel, arrancaram a cerca que circunda a capela, inutilizaram os arames fizeram com os mourões a fogueira de São João. Como o Governo Waldomiro Lima era protetor dos bandidos (socialistas e comunistas, i. (isto) é anticlericais) não foi possível tomar as necessárias providências [...] $]^{391}$

O vigário deu parte na polícia, no entanto os infratores não foram punidos e a igreja novamente se viu prejudicada.

O registro do vigário da Penha nos dá uma idéia do que significou o fato para a população do Cangaíba e para a Igreja, “[...] devido a êsses acontecimentos, que não foram reprovados pelo povo, o vigário resolveu não celebrar mais missa no bairro, ainda mais que os pais tiraram todas as crianças do catecismo."392 Onde se concentravam massas de operários, a palavra da Igreja não apresentava a força.

Mesmo diante deste quadro, as festividades na Penha continuavam intensas. Sempre acompanhadas pelas quermesses, as festas geravam lucros aos comerciantes, empregos e aumento da arrecadação na paróquia, porém a festa já não era mais dirigida pelos padres. O serviço agora ficava nas mãos do 'festeiro', indivíduo especializado contratado para a realização e organização das festividades. O festeiro reservava parte da

${ }^{391}$. Ibidem, p.61v. 
receita ou um valor pré-estipulado que deveria ser entregue à igreja e o restante do arrecadado era o seu pagamento.

As festas eram uma das poucas garantias de arrecadação da igreja da Penha. Conforme Livro Tombo, grande parte da população penhense dos anos 1930 era pobre, tanto que evitavam casar na igreja para não ter gastos com a união. Os casais efetuavam apenas o contrato civil e alegavam que não possuíam dinheiro para o pagamento do casamento religioso. $^{393}$ Outro exemplo foi a coleta de 25 de Janeiro 1934 que, “[...] infelizmente rendeu pouco devido a pobreza da população penhense.”394

A igreja associava o crescimento dos movimentos de esquerda e das outras religiões à pobreza da população. Nas festividades do Natal de 1934, a Igreja distribuiu muitos presentes às crianças, alegando que a distribuição de presentes era

[...] uma medida salutar para a paróquia onde o povo é paupérrimo e onde existe grande propensão para o comunismo e o espiritismo. É sabido que este último em toda a parte e, de um modo especial na Penha, se procura então introduzir sob o manto da filantropia e beneficência virando uma religião de caridade como outr’ora o maçom. É necessário desmascara-la e contrapor obras de caridade de que dêm na vista e mostram a todos que o Catolissismo é por excelência a caridade verdadeira por amor a Deus. Neste ponto as Damas de caridade e os vicentinos da paróquia prestaram relevantes serviços e já convertido grande número de comunistas e espíritas ignorantes, chamando-os à prática da piedade $[\ldots]^{395}$

As intervenções do Estado no espaço penhense tornavam-se cada vez mais comuns e chegou até a igreja. Em 1935, a Prefeitura de São Paulo interditou a igreja penhense, pois seu teto estava com problemas e ameaçava cair e seu espaço físico pequeno tornara-se um perigo para a segurança de tantos fiéis.

O problema já vinha de longe, segundo Jornal Mensageiro de Nossa Senhora da Penha de 1929,

[...] não é de hontem que se sente na Penha a necessidade de uma egreja mais vasta. A população da parochia que ainda em 1901, conforme resenceamento daquelle anno, foi de 2.873 almas subiu entretanto a cerca de cincoenta mil. O número de devotos da virgem da Penha que de toda a capital a este santuário, aumentou extraordinariamente com a facilidade das comunicações. ${ }^{396}$

Assim, a paróquia passou a arrecadar dinheiro com quermesses, esmolas, contribuições mensais, entre outros. O templo praticamente possuía as mesmas dimensões e alvenaria do tempo do Padre Jacinto Nunes de Siqueira de 1682 e era considerado:

[...] um pardieiro indigno de Nossa Senhora e da Capital Paulista. Além das paredes laterais externas de $1.20 \mathrm{~ms}$ de espessura, havia outras internas de sorte

392 . Idem.

393 . Ibidem, p.65v.

394 . Ibidem, p.66.

395. Ibidem, p.69 e 69v.

396. Mensageiro de Nossa Senhora da Penha. Publicação da Parochia da Penha, nº1, Anno I, São Paulo, janeiro de 1929, p.1. 
que o local entre as duas paredes ficava [?] inutilizado para o público. Como o altar-mor se achava quase no centro da igreja, o espaço para o povo era diminuto, comportando quando muito 600 (seiscentas) pessoas, embora, de parede à parede, a igreja tivesse 46ms de comprimento. Para ganhar espaço, o vigário mandou demolir todas as paredes internas deixando da igreja velha apenas as quatro paredes externas. Não demoliu também estas $1^{\circ}$ por motivo da economia, $2^{\circ}$ para evitar que a prefeitura da cidade, com intuito de alargar a rua, impedisse a reconstrução do templo. Se não fora estar na prefeitura o Sr. Antonio Carlos de Assunção, não teria sido possível reforma alguma porque os funcionários dessa repartição pública exigiram que comprovasse ser a Cúria a proprietária do terreno [...] as paredes laterais foram lavadas e uniformizadas. Numerosas janelas foram abertas para necessária ventilação; o altar foi recuado para traz [...] com o fim de isolar a sacristia o vigário fez um requerimento à prefeitura pedindo uma área atraz da igreja para lá levantar a sala de expediente paroquial. Após muitos aborrecimentos de seis meses a prefeitura reclamou não poder ceder gratuitamente a área desejada, surgiu, por'me, uma permuta $[\ldots]^{397}$

Em 18 de fevereiro de 1936, correu a permuta entre o "terreno da Vila Santana pela área atraz da igreja $[. . .]^{398}$

Na década de 1930, o lazer fora do controle religioso começa a se estabelecer como importante fator de aproximação entre os moradores da localidade. Além das festas religiosas e do cinema da paróquia, o Cine Penha, a prática de esportes e o "footing" também passa a se destacar.

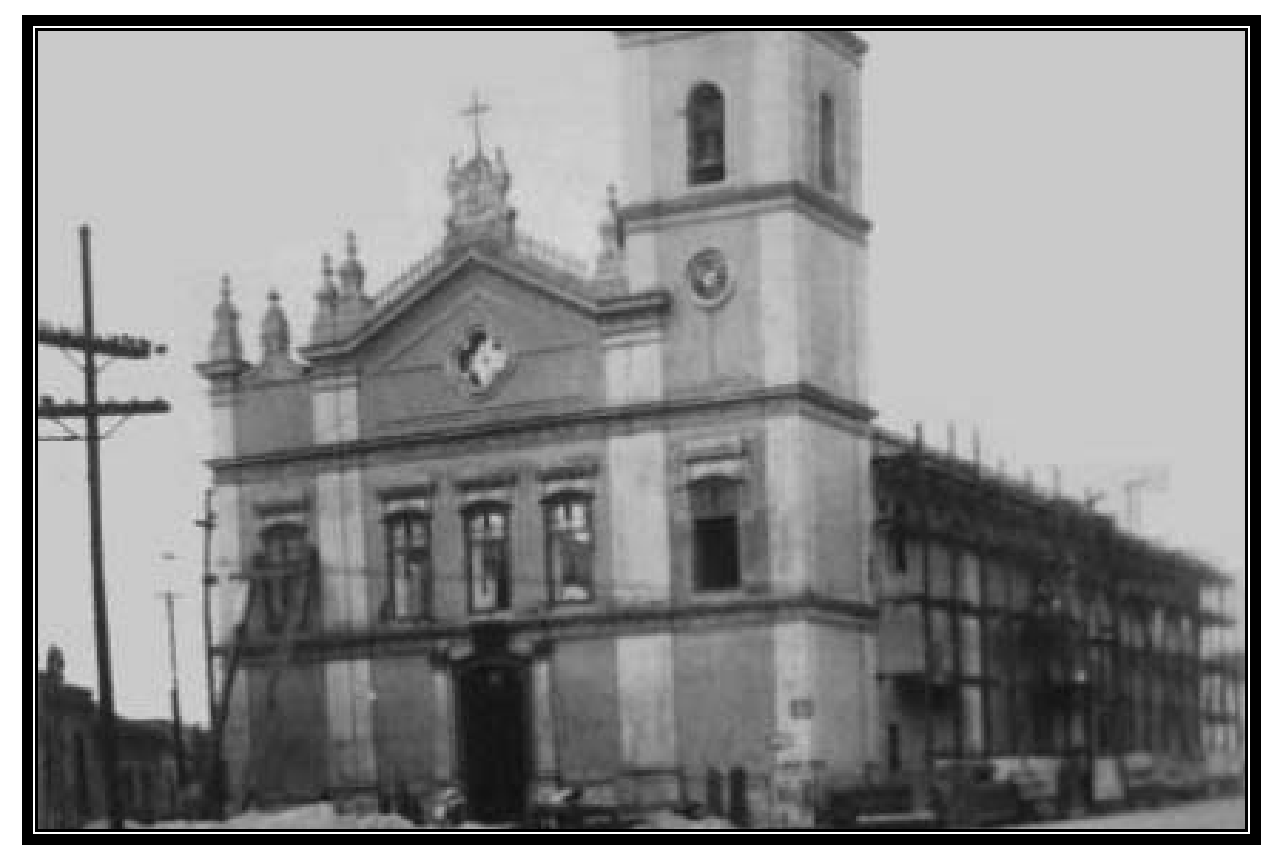

Reforma da Igreja de Nossa Senhora da Penha em 1934 - O teto foi elevado e recebeu pinturas sacras de Alfredo Cespi. (Memorial da Penha de França, acervo digitalizado)

397 . Cf. Livro Tombo da Freguesia de Nossa Senhora da Penha - Livro Códice 8-3-12, aberto em 1933, p.78.

${ }^{398}$. Ibidem, p.79v. 


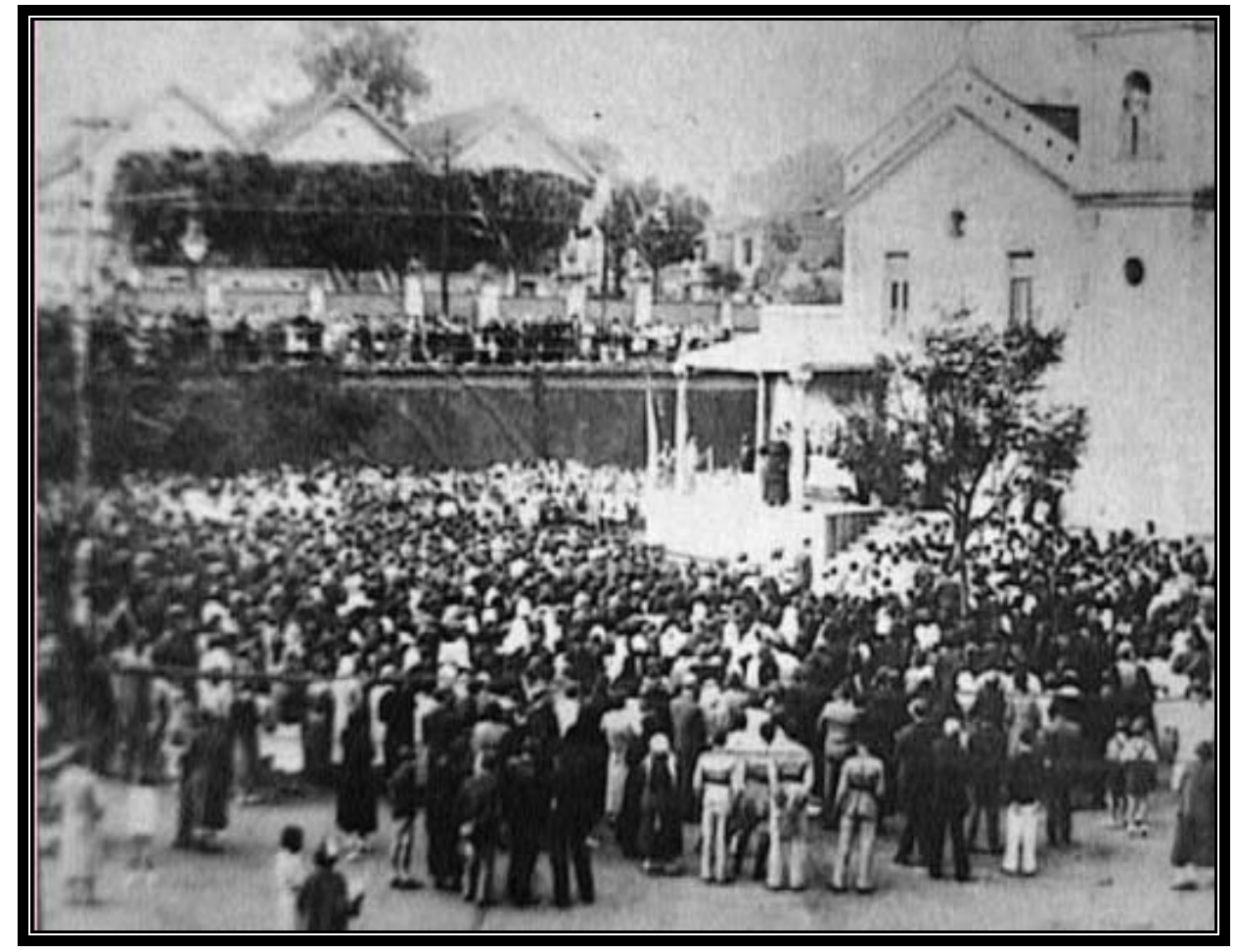

Missa no Largo do Rosário em 1935 - Enquanto não se terminava a reforma na igreja de nossa Senhora da Penha a população se apinhava para a missa em frente a Igreja do Rosário. (Memorial da Penha de França, acervo digitalizado)

O desenvolvimento das atividades esportivas na Penha apresentou-se como reflexo da modernização das práticas sociais presentes no processo de industrialização e urbanização da cidade de São Paulo. Acreditamos que tais práticas, ao mesmo tempo em que reforçavam as relações sociais da localidade, também proporcionavam a desestruturação dos antigos valores sociais estabelecidos ao longo de séculos. Assim, como aconteceu com o cinema, o esporte passou a inserir novos conteúdos na vida cotidiana da localidade e mostrou-se eficiente na capacidade de centralizar práticas sociais.

Na Penha dos anos de 1930, entre os esportes mais praticados se destacavam o futebol varzeano, a natação, a molha, a bocha e o remo.

Em prefácio para o livro de Mário Rodrigues Filho, Gilberto Freyre observou que o futebol aparece como "uma contribuição valiosa para a história da sociedade e da cultura brasileira na sua transição da fase predominantemente rural para predominantemente urbana [...] o 'foot-ball' teria numa sociedade como a brasileira, em grande parte formada por elementos primitivos em sua cultura, uma importância especial 
que só agora vai sendo estudada [...].”399

Segundo Seabra, desde os primeiros anos do século vinte, o futebol tornou-se uma febre que foi invadindo as ruas, os quintais, as portas das fábricas, terrenos baldios e toda a sorte de espaço que permitisse sua prática. Enquanto prática lúdica, o futebol apresentase mais uma das novas sociabilidades que a industrialização impunha. ${ }^{400}$

Em pouco tempo vários times (de cidade, de bairro, de fábrica, de escola, de paróquia, de vila, de rua) começaram a se defrontar pela cidade.

Em seu estudo sobre o Bairro do Limão, Seabra observa que

[...] esse futebol de várzea de São Paulo pode ser entendido como a primeira grande festa do povo fora da Igreja. Não obstante, tanto as paróquias como os colégios católicos, empreenderam grandes esforços para assimilar os impulsos que vinham do futebol, e até conseguiram, em muitos casos, seus intentos. Foi como conjunto de práticas lúdicas, definidas como âmbito próprio, como coisa do povo que, paradoxalmente, a Igreja, imiscuindo-se nelas, visava dar continuidade às suas práticas paroquiais. ${ }^{401}$

Seabra observa ainda que a Igreja via no futebol uma forma de sustentar sua hegemonia á medida que ele "como festa progredia pela sociedade. Em decorrência, a presença dos padres e políticos tornaram-se constantes nos campos e em todas as lides do futebol. Através do futebol procuravam estar junto do povo.”402 Segundo a autora, outra questão que levou a Igreja a se interessar pelo futebol foi o fato de que para comunistas e anarquistas, ele era considerado parte do processo de alienação da classe trabalhadora, e nesta condição tornava-se forte arma no projeto político de combate ao crescimento destas ideologias entre a classe trabalhadora. Assim, no caso do Bairro do Limão, Seabra observou que desde 1924 a Igreja tornou o futebol parte da estratégia de dominação, tanto que o campo do principal clube do bairro, o A.A. Açucena ficava praticamente no quintal da Igreja e sob o olhar atento do vigário local.

Essa aproximação entre futebol e Igreja não foi observada na Penha, pelo menos na mesma intensidade da ocorrida no Limão. Em nossas pesquisas pudemos observar que o futebol era bem difundido na região, no entanto carecia de organização e prestígio e assim, poucos foram os clubes que se destacaram. ${ }^{403}$

Na Penha das décadas de vinte e trinta do século passado, os dois únicos clubes que se destacaram e chegaram a ser considerados e respeitados na prática do futebol organizado foram o Spartano Futebol Clube, fundado em 1913 que reunia a elite do bairro

399. FREYRE, Gilberto. Prefácio. In: RODRIGUES FILHO, Mário. O negro no futebol. Rio de Janeiro: Editora Pingetti, 1947, p.17 apud SEABRA O. L. C., op. cit., 2003, p.270.

${ }^{400}$. SEABRA O. L. C., op. cit., 2003, p.271.

401 . Idem.

402. Ibidem, p.271.

403. SANTARCANGELO, M. C. V., op. cit., 1968, p.36. 
e o Clube Atlético Penhense, que reunia pessoas da classe média. As sedes e campos de ambos antigamente se localizavam na Rua Francisco Melchiori. ${ }^{404}$

Poderíamos citar ainda o Palmeira Futebol Clube, fundado em 1930, cujo campo e sede se localizava na Rua Militerno; o Clube Atlético Guarani, fundado em 1934, antigamente localizado na Rua Otilia; o Estrela D’Alva Futebol Clube, fundado em 1938 e que se localizava na Rua Mirandinha e por fim o Associação Atlética Guaiaúna, fundada em 1940, na Rua Julio Colaço. Infelizmente não encontramos maiores referências sobre estes. ${ }^{405}$

Porém, em nenhuma parte dos documentos da Igreja que consultamos pudemos encontrar qualquer referência sobre clubes de futebol e mesmo nas entrevistas ele apareceu como algo realmente relevante.

Segundo Seabra:

Clube, futebol e política formam uma unidade problemática que acompanha a modernidade desde a origem e compreende níveis de estruturação que vão do âmbito local ao internacional. Relativamente ao futebol, o clube de bairro chegou a ser o nível mais elementar dessa articulação. Agora, o clubismo e o bairrismo, andando juntos, podem funcionar como uma política de bairro e, neste sentido, chegar a ser restrição à política. De todo o modo, nos alvores da industrialização, quando a população proletária se acomodava nos arrabaldes da cidade, formaramse lideranças locais que se envolveram desde muito cedo, aqui em São Paulo, com o futebol. Conhecidos por paredros, os articuladores do futebol nos times, grêmios e clubes, faziam política a partir do nível local. Nesse sentido, essas organizações voluntárias, como eram os clubes, serviam à formação e estruturação da vida civil e pública. Os contingentes de população migrante encontravam nos clubes a porta de entrada nessa sociedade mais complexa criada pela industrialização. ${ }^{406}$

No bairro em análise, coube ao CEP, Clube Esportivo da Penha, assumir esse nível de articulação social. O interessante é que neste clube, o futebol nunca se apresentou como esporte de destaque.

Fundado por Plínio Augusto de Camargo em $1^{\circ}$ de Janeiro de 1930, o Clube Esportivo da Penha tinha como principal propósito reunir “aficionados e amadores” interessados nas mais diversas práticas esportivas. ${ }^{407}$ Segundo entrevista,

[...] no Clube Esportivo da Penha até tinha futebol, mas seu forte mesmo eram as atividades poliesportivas. $\mathrm{O}$ forte do clube mesmo, dos esportes no período de sua inauguração, era o boxe, o basquete [bola-ao-cesto] e principalmente os esportes aquáticos, o remo e a natação. O Clube participou de muitos campeonatos, mas atualmente anda meio parado."408

Os jogos de malhas e a bocha também se destacavam no clube.

Durante as décadas de 1930 e 1940, o Clube se apresentou como importante

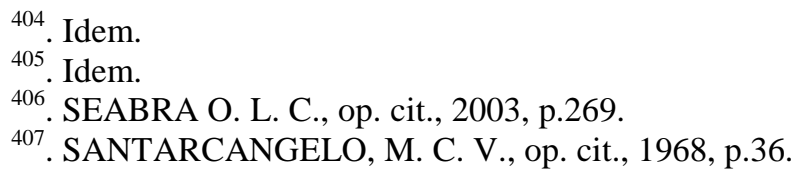


referência no cotidiano da população penhense. Nele, qualquer penhense era bem-vindo e não se fazia qualquer discriminação de classe. Podemos perceber que em nível de articulação da vida local, o clube começou muito bem. Segundo entrevista:

$\mathrm{O}$ rio era violento com grande correnteza e [...] tinha os grandes batelões que navegavam cheios de areia e tijolos, pedregulho e lenha. Parecia que iam afundar, pois todos com enormes varejões e lemes que eram manejados com os pés e a água a pouco menos de uns dez centímetros do lado de fora, mas os barqueiros eram alegres e cantavam, assobiavam e iam descendo rio abaixo. Mas em algumas partes do rio se formavam pequenas praias onde as crianças e adultos costumavam ir nadar à tarde, aos sábados, domingos e feriados. Em quase toda a margem do Tietê havia essa recreação. Nossa prainha, aqui onde está o nosso clube, foi escolhida pelos adultos daquela época, para fazerem aqui um clube (1929). Começou o "disque-disque" que iam fazer o tal clube. Os freqüentadores não gostaram da idéia, mas a coisa pegou.

O Sr. Plínio e mais alguns senhores (uns 12 ou 13 homens) deram início ao clube. Em um domingo do mês de dezembro, chamaram os garotos que eram os donos da prainha, onde vinham nadar sozinhos e outros acompanhados de seus pais ou parentes. Primeira reunião ficou marcada para a prainha que era nossa e que nós não íamos pagar nada, mas que precisava trazer um calçadinho, o nome do pai e da mãe e onde moravam.

Durante a semana começaram a construção de barracos, o que os garotos não gostaram. A noite eles desmancharam tudo e jogaram no rio. Domingo seguinte, um dos garotos era filho do Sr. Maneco, que era filho de um dos homens que faziam parte daqueles que queriam fundar o clube convenceu os colegas a participarem da construção.

Assim fomos para a reunião e concordamos com eles. O Sr. Plínio pediu que quem tivesse enxadas, enxadão, foice, carrinho, serrote, martelo, picareta, facão, prego, enfim, que fosse útil para começar o trabalho do clube...'tudo combinado, agora mãos-à-obra'.

Domingo, dia 30 do mês de janeiro de 1930, às 6 h30 da manhã começaram a chegar os primeiros voluntários para a construção do clube. Às 8 h já estavam todos os membros adultos do clube, que iam discutir o nome do clube.

Os garotos que eram mais ou menos 15, cada um começou a fazer o seu trabalho, cortar árvores, cavocar, limpar o terreno. Era uma beleza ver o entusiasmo dos meninos. Nesse instante o Sr. Plínio e a comissão disseram: 'Atenção um minuto: ficou resolvido o nome do clube [?] pela comissão dos que ali se reuniram e discutiram... agora o nosso clube vai se chamar Clube Esportivo da Penha", fundado em $1^{\circ}$ de janeiro de $1930 \ldots$ e aqui nesta caderneta fica constado o nome de vocês todos, unidos para o bem do clube'. 409

O CEP já nasceu inserido em um processo de organização voluntária e em pouco

tempo tornou-se referência e orgulho na Penha. Tal sentimento é possível de se constatar

em entrevista:

O Clube Esportivo da Penha, que hoje é um clube grande, é um clube que presta respeito, nasceu em 1930. Grandes clubes, como o Atlético Penhense, tinha o Artemius? Tinha o Espartano. Tinha o próprio Guaiaúna. Clubes de respeitos, [...] o bonde que chegava das quatro e meia e cinco horas era um tal de todo mundo correr para chegar logo em casa, se trocar, isso e tal e ir para clube, ir para os clubes. Os clubes eram todos simples, viu? Eram tudo barracões. Então a gente pegava, chegava, mas era tão gostoso que a gente bebia água no Tietê. A água era tão limpa! $!^{410}$

${ }^{408}$. Entrevista com o Sr. Alípio (junho/ 2006).

${ }^{409}$. Sr. Luíz Several Maciel. Entrevista concedida ao site do Clube Esportivo da Penha, 1996. Disponível em http://www.cepenha.com.br/index1.htm. Acesso em 30 junho 2006.

${ }^{410}$. Entrevista como o Sr. Pacha (maio/2002). 


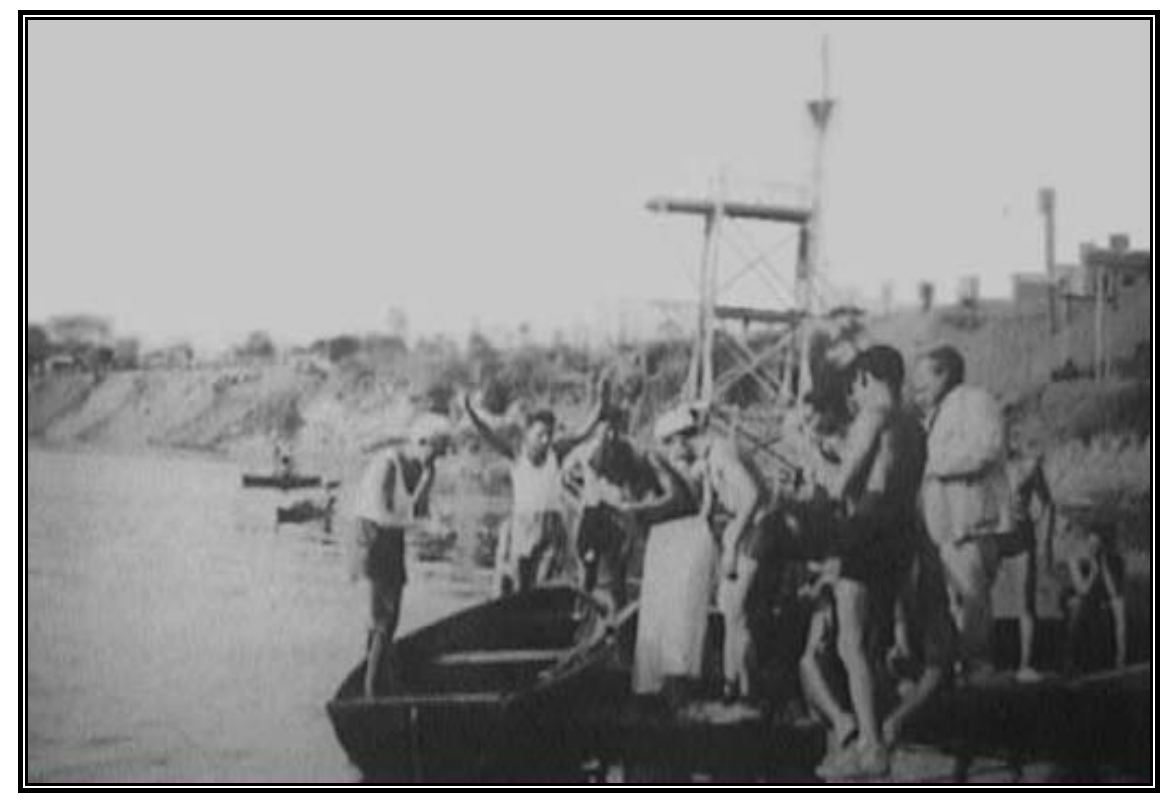

Clube Esportivo da Penha em 1931 - O clube surgiu em 1929 e teve em Plínio Augusto de Camargo, de pé dentro do barco, o seu maior idealizador. (Memorial da Penha de França, acervo digitalizado)

Tal depoimento nos revela a importância do lúdico e do lazer no período de ócio e a valorização do encontro na Penha. Que tipo de encontro? Principalmente o familiar. Segundo entrevista, no dia da inauguração,

[...] era um feriado e eles [os sócios] trouxeram os seus familiares que juntos com os garotos presentes fizeram uma linda festa, com comes-e-bebes à vontade. Para alegria de todos começou uma união de famílias penhenses que contribuíram com tudo que podiam [...] Aos domingos aqui era sempre uma festa. As famílias se reuniam, os homens trabalhavam, as mulheres aprontavam deliciosas comidas que eram colocadas em uma só mesa. Essa união crescia cada vez mais. ${ }^{411}$

E nos anos seguintes, o encontro das famílias tornou-se parte das atividades no CEP, “aos domingos, o clube parecia dia de festa, pois a entrada era franca e os rapazes, moças, senhoras, homens e crianças vinham passear nas tardes de domingo. Só não podiam entrar nos vestiários porque não eram sócios. ${ }^{„ 412}$

Assim, o Clube Esportivo da Penha apresentou-se como modernização das práticas sociais na localidade, como nova possibilidade de encontro para as famílias que até então só possuíam as atividades relacionadas à Igreja. O CEP aparece como modernização e fortalecimento da vida de bairro.

411 . Sr. Luiz Several Maciel.
412 . Idem. 


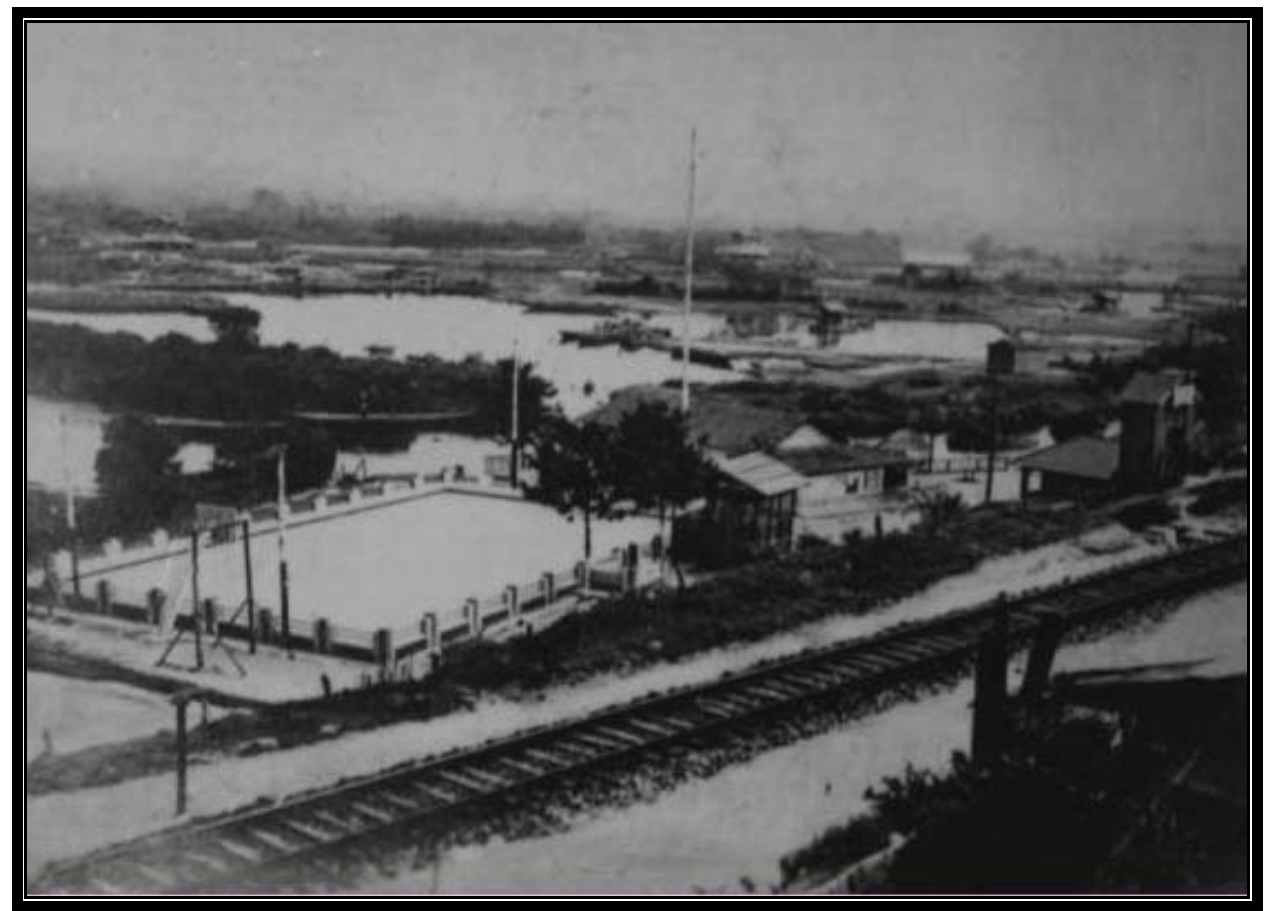

Clube Esportivo da Penha em 1934 - No plano primeiro podemos observar o Ramal Poá da Central do Brasil e ao fundo, as curvas do rio Tietê, onde em suas águas ainda limpas se praticava o remo, a natação, o salto e a pescaria. (Memorial da Penha de França, acervo digitalizado)

Um aparte, segundo Sr. Alípio, quando questionado sobre a participação da Igreja na estruturação do Clube, “a Igreja nada teve a ver com isso, a gente ficava aqui embaixo e ela lá no topo, né? [...] Os padres não participaram de nada aqui." "413 Claro ficou que o Sr. Alípio estava se referindo a questão topográfica, mas não dá para não se sentir induzido a refletir sobre o que já foi discutido aqui: a posição e a distância que a Igreja estava da população menos favorecida. Dá para se pensar na possibilidade de existir uma Penha de cima, a da colina onde estava a igreja, o comércio e as famílias mais abastadas e uma Penha de baixo, o entorno da colina, próximo as várzeas, onde morava a população mais carente.

Outro importante fenômeno que reforçava a vida de bairro na década de 1930 era o "footing". ${ }^{414}$ Segundo entrevista:

Aqui era, era um núcleo que a gente tinha muita amizade. Então, fazia-se reuniões na, nestas confeitarias. Encontrava-se com amigos, batia-se um papo. Às vezes encontrávamos, aí, uma turma de músicos, 'né'? Naquele tempo havia muitas serestas. O pessoal se reunia, ouvia um toque de violão, etc. E assim, passava-se o dia. Esperava-se o Sábado e o Domingo, tinha o "footing" aí na Penha. Muito bonito, gostoso, 'né'?’[O footing] era um passeio, aí. O passeio se resumia da, do largo aí. O bonde fazia aquela curva, ali, e seguia para a Comendador Cantinho e era dessa avenida, praça Oito de Setembro até a igreja,

413 . Sr. Alípio.

414 . "Footing” era um passeio a pé pelo bairro. Segundo Sr. Fábio, no “footing”, que se intensificava após as missas, as famílias passeavam pela praça, tomava-se sorvete, comia-se doces e salgados, moças e rapazes se exibiam, paqueravam; geralmente durava até umas 21 horas, depois a praça começava a se esvaziar rapidamente. 
'né'? Os homens ficavam no passeio e as meninas andavam no meio da rua. Muito gostoso.

Se vivia bem por que a sociedade penhense era muito boa na época. Então a mocidade nossa, aqui, foi assim: vivia-se aqui no dia-a-dia. Esperava-se o sábado e o Domingo pra ir num "footing" na Penha, que era muito interessante. Nós tínhamos ali no Largo do Rosário uma banda de música. Que era como se fosse uma cidade do interior, aqui, "né”? Tínhamos muitas amizades. De tarde, antigamente era muito bom aqui na Penha. Hoje não tem mais.

Propriamente o dia mais querido do bairro era o sábado. No sábado, já pela manhã, era predominante o semblante e o sorriso dos moradores, [...] era um hábito muito alegre dos moradores, geralmente sempre aos sábados, quase que em todas as casas é, celebração de aniversários, de casamentos e se fazia festas [...] todos, faziam parte.

Depois uma coisa. Naquele tempo havia muita festa, viu? Primeiro vinha a Páscoa, depois da festa da Páscoa, vinha a Pascoela. Então, geralmente, dos que moravam fora da Penha, tinham caminhões, carroças, e vinham fazer a Pascoela aqui na Penha. Aqui era tudo mato. Era muito bonito! Tinha biquinhas de água boa, viu? Em tudo quanto era lugar. [...] eu quando me recordo até quase que choro de saudade. ${ }^{415}$

A Penha, principalmente para os homens, também se refazia no período noturno,

nos bares, nas padarias, nos clubes e onde era possível jogar cartas, dominós, dados e

\section{bilhar. Sobre a vida noturna, segundo entrevista,}

[...] antes, eram noites gostosas! Aqui, morava muitos intelectuais. Ficavam aqui pela, pela noite adentro, não é? Ficavam, às vezes até quatro ou cinco horas da manhã e aqui não tinha nada. Como fechavam o comércio que a gente descia e vinha para casa dormir. ${ }^{416}$

Em entrevista, Sr. Pacha reforça nossa analise:

Havia muito jogo de truco, truco. Haviam muitos clubes, geralmente o esportivo (?). Durante a noite, o pessoal se reunia para se distrair, né? Jogar dados, bebericar... e era muito divertido, viu! Sabe havia serenatas, me pegava pelo rabo, viu!. Um dia a turma se juntou comigo e fomos fazer uma serenata na rua Francisco Coimbra, lá na casa de um português que tinha umas filhas muito bonitas e um dos amigos tinha ficado apaixonado por uma delas e fomos fazer a serenata. Era mais pra baixo que uma e meia, duas horas da manhã e nos pusemos lá na (?) em um ponto, o português abriu a janela, pegou um penico e...nem precisa falar, né. $^{417}$

415 . Entrevista com Sr. Fábio (maio/2002)

${ }^{416}$. Idem.

${ }^{417}$. Sr. Pacha. 


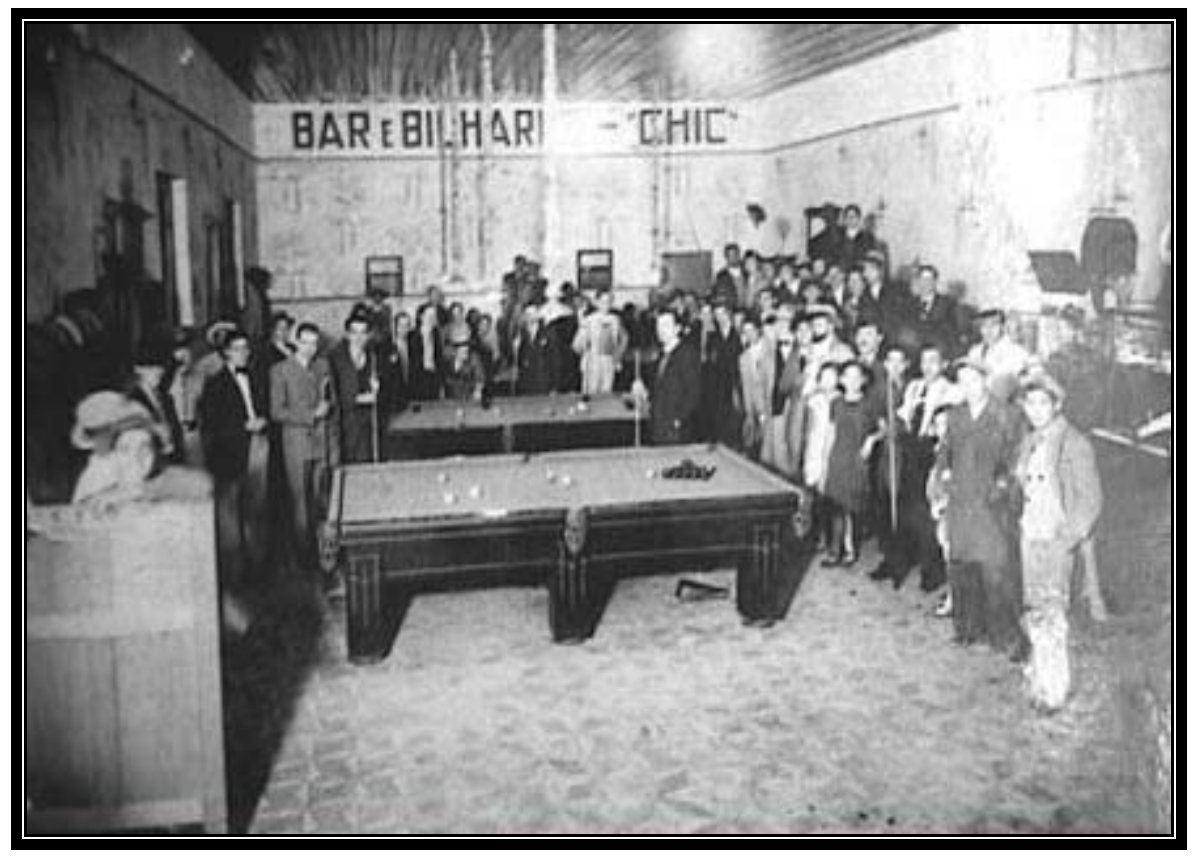

Bar e Bilhar Chic em 1935 - Localizado na Avenida Penha de França, o bar era um dos locais onde jovens e cavalheiros se reuniam após "footing” e terminavam a noite. (Memorial da Penha de França, acervo digitalizado)

A Penha da década de 1930 era, assim, um subúrbio que mesclava posturas e elementos modernos, que se estabeleciam conforme as necessidades de seus moradores de vanguarda e que tentavam reproduzir na localidade os confortos e maneiras do viver dos seus correlatos na cidade de São Paulo, com posturas e elementos vinculados ao seu passado rural. Este era o caráter essencial do subúrbio penhense, a transição entre rural e urbano.

Antes de partir para o próximo capítulo, que visa identificar como esses elementos e posturas se alteraram com o processo de metropolização, faz-se interessante delinear alguns elementos da paisagem penhense. Isso se justifica pela relevância dos mesmos para as análises que se seguirão.

Os elementos da paisagem rural ainda estavam muito presentes no subúrbio Penha da década de 1930. Segundo entrevista:

Aqui nas redondezas do clube, que não existia ainda, era formado por chácaras, sítios, grandes quintais, olarias, grandes pastagens para animais. O rio Tietê era feito uma cobra, todo com grandes curvas, água muito corrente, limpa e em seu redor muitos lagos e pequenos riachos. Havia criação de vacas, bois, cavalos, cabras, coelhos, galinhas etc. Às tardinhas as pessoas costumavam pescar no rio e pegavam muitos peixes - dos bons e grandes - assim como bagre, piava, traira, lambari, mandi e muitos outros peixes. Isso em poucas horas. [...] Os passarinhos que eram em grande quantidade, cantavam e voavam de árvore em árvore. Muitos bichos, assim como lagartos, tatus, cobras etc. ${ }^{418}$

Os produtores rurais penhenses, além de atividades criatórias, dedicavam-se à

${ }^{418}$. Sr. Luiz Several Maciel. 
produção de legumes, verduras e flores, que eram comercializadas na capital. A produção e a comercialização eram transportadas para a cidade tanto em carroças e bondes, pela Avenida Celso Garcia, como pela ferrovia central do Brasil. Grande parte da produção era fruto do uso agrícola das várzeas, onde predominavam portugueses, conhecidos como "verdureiros".

No aglomerado, o comércio era diversificado e se destacava como centro de convergência da região. O comércio era representado por lojas de armarinhos e de ferragens, de artigos religiosos, farmácias, barbearias, restaurantes, lojas de roupa, entre outras, e um pequeno equipamento para atendimento dos visitantes (hotéis e pousadas).

A Penha se despontou como centro regional tornando-se ponto de partida e chegada obrigatório para os que se deslocavam da cidade para os aglomerados vizinhos e vice-versa. Os meios de transportes eram sofríveis e o bonde começava ser descartado pela população. Os trens já andavam lotados, mas era preferível pegar o trem á correr risco de se acidentar no bonde. Segundo entrevista, "tanto o bonde como o trem eram sobrecarregados. Hi! Quando chegava às cinco horas da tarde, para se vir aqui pra Penha, vinha-se de subúrbio, se vinha que vinha apertado. De bonde tinha desastres, acidentes a toda hora. De gente que morria esmagado, isso era ruim." ${ }^{419}$ Por ser ponto de parada obrigatório para baldeamento entre transportes, o adensamento urbano na colina foi inevitável.

Junto ao comércio e casas de prestação de serviço moravam os proprietários e de seus empregados, patrões no piso superior ou no fundo da loja, subordinados no porão ou em cômodos no fundo dos terrenos. Quando não era possível, esses empregados se estabeleciam nas baixadas da Penha, nos novos loteamentos da região ou, principalmente, em lugares mais distantes, onde os salários desses permitissem. Segundo entrevista, “aqui tinha muito, muito português e muito caipira. Os caipiras era, geralmente, esse pessoal que vinha de Santa Isabel, Guarulhos... eles vinham trabalhar aqui na Penha. Era os que vinham geralmente de São Miguel. "420

419 . Sr. Fábio.

${ }^{420}$. Sr. Pacha. 


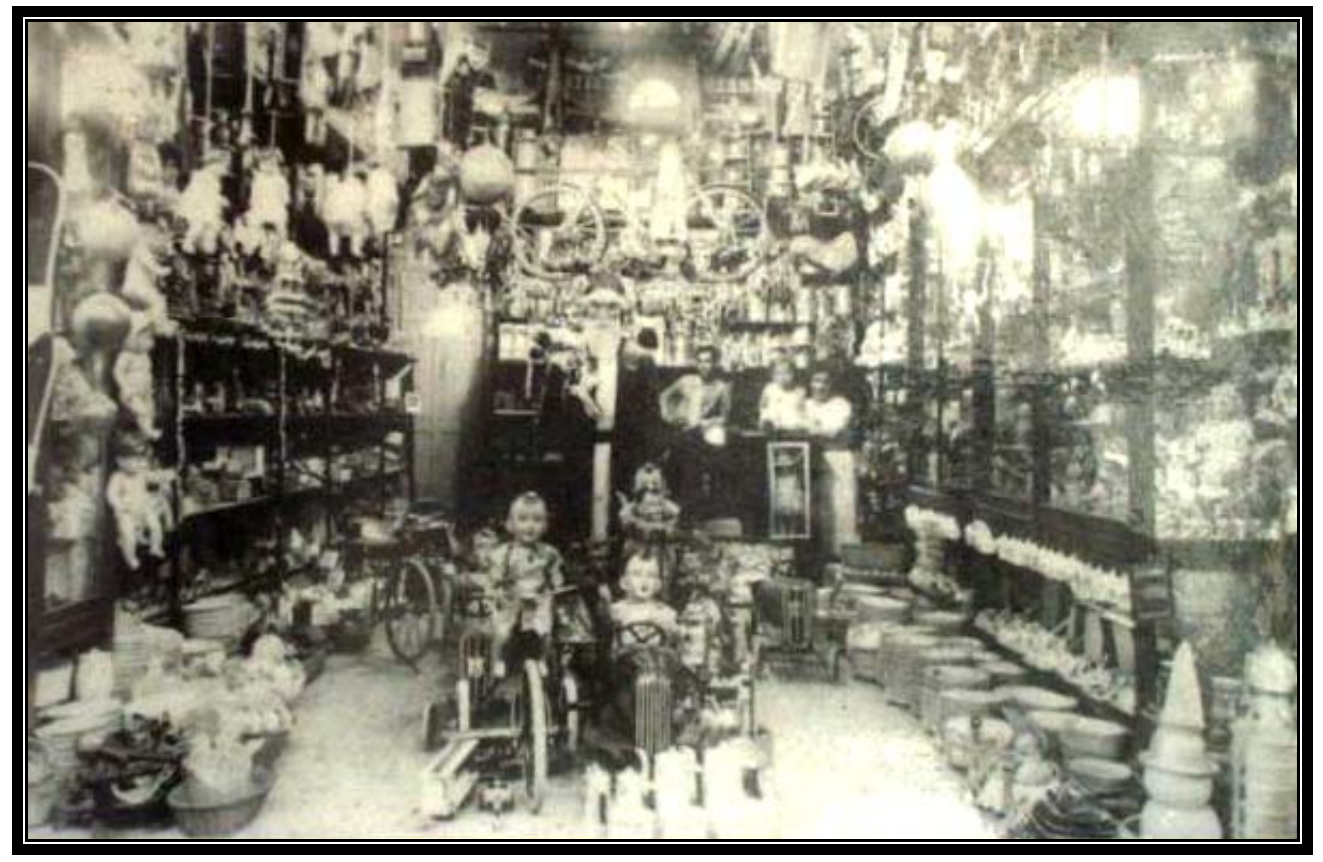

Loja Luiza em 1938 - Uma das características das lojas de bairro era a diversidade dos produtos. (Memorial da Penha de França, acervo digitalizado)

Os embates ideológicos aumentavam e proporcionavam cisões cada vez maiores no cotidiano penhense. Eram confrontos entre católicos e espíritas, entre católicos e evangélicos, entre católicos e esquerdistas, entre católicos e os que profanavam o espaço e a simbologia da Igreja; eram conflitos entre sociedade tradicional do bairro, formada pelos donos dos negócios e religiosos, e a classe operária, formada por uma grande massa de imigrantes e seus descendentes; enfim, era o confronto entre as velhas posturas, na luta pela preservação de uma hegemonia econômica e sócio-cultural, e as novidades que urbanização e a industrialização impunham.

A coesão do subúrbio começava a se diluir diante da superficialidade das relações humanas que as formas do viver nas metrópoles proporcionam. Caberá ao próximo capítulo delinear como essas se processaram na vida e no espaço penhense. 
CAPÍTULO 3 


\subsection{Considerações iniciais.}

Como pudemos observar, a chegada da ferrovia na localidade proporcionou melhoria nas condições de infra-estrutura, estimulou negócios imobiliários, estabeleceu novas funções (estimulou os setores de comércio e serviços), desenvolveu novos hábitos do viver e de organização social.

As áreas rurais, que ocorriam em torno do núcleo central da Penha e ao redor das estações ferroviárias Carlos de Campos e Vila Matilde passaram, a partir da década de 1930, a ser transformadas em loteamentos para moradia de operários, comerciantes e demais trabalhadores da cidade.

Junto às ferrovias, avançou a indústria e todo o processo de transformação que ela representava. Para suprir a mão-de-obra necessária para estas indústrias, vários loteamentos operários se estruturaram, sendo a maioria deles às margens dos trilhos das ferrovias e as antigas estruturas urbanas como a Penha foram rearranjadas para atender às novas necessidades. Assim, novas formas de uso para o espaço urbano passam a se desenvolver.

As novas formas de uso do espaço também se apresentaram como novas formas do uso do tempo. O tempo do sino e do galo foi substituído pelo tempo dos apitos dos trens e das fábricas e, na mesma proporção, a difusão do dinheiro passa a definir-se rapidamente como mediador fundamental das relações na vida de bairro. O resultado deste processo foi o aparecimento de novos modos de vida. ${ }^{421}$

As novas estruturas e formas do urbano, junto ao crescimento acelerado da população, começaram enfraquecer as antigas referências tradicionais (religiosas e rurais) da localidade e, assim como Seabra identificou no Bairro do Limão, o paroquialismo ruindo diante das novas formas abstratas de poder, também na Penha as formas tradicionais do viver foram sendo subjugadas.

Essas novas formas passaram a articular os momentos da vida dos moradores e a Igreja, que tão de perto acompanhava a reprodução da vida e o uso dos espaços, foi perdendo sua hegemonia.

Tal processo, teve seu impulso maior a partir de 1940, quando a cidade apresentou enorme crescimento populacional e os vazios deixados pelos loteamentos anteriores, que mantinham a Penha isolada foram de vez ocupados. ${ }^{422}$

${ }^{421}$. SEABRA, O, C. L, op. cit., 2003, p.140.

${ }^{422}$. MARTIN, A. R., op. cit., 1984, p.160. 
Segundo Martin, “ao mesmo tempo os antigos subúrbios ferroviários eram incorporados ao tecido urbano metropolitano, foram sendo formados novos subúrbios ainda mais afastados." ${ }^{423}$ A Penha, enquanto subúrbio próximo não fugiu à regra e tornou-se parte deste tecido urbano da cidade.

A partir dos anos 1940, a circulação de automóveis, caminhões e ônibus também aumenta e, a partir da década de 1950, circular pela metrópole paulistana nestes meios de transporte já havia se tornado uma tarefa ingrata.

Tal fato favoreceu o fortalecimento dos antigos e mais bem estruturados subcentros (Pinheiros, Santana, Lapa e Penha) ${ }^{424}$ que, para atender as necessidades de uma população que sofria para chegar até o centro da metrópole, passaram a ter equipamentos comerciais e de serviços mais sofisticados.

Assim, diante do avanço dos processos de urbanização e de industrialização e da conseqüente configuração da metrópole paulistana, as antigas centralidades fortaleceramse, na mesma proporção que outras surgiram. ${ }^{425}$

Como resultado, a metrópole se apresenta como estrutura policêntrica.

A década de 1940 marca a transição entre a Penha subúrbio e a Penha fragmento da metrópole. Neste momento podemos observar o ápice da Penha enquanto bairro paulistano junto com o anúncio do fim da vida de bairro, onde o espaço do viver e das relações de vizinhança entra em dissolução.

A pesquisa constatou, principalmente a partir das entrevistas, que a vida de bairro na Penha teve curta duração. Assim que a condição de subúrbio desapareceu, a vida de bairro tomou corpo e se intensificou, no entanto, não conseguiu se manter diante das novas práticas sócio-espaciais do viver associadas à industrialização e ao processo de metropolização. Deste modo, as relações de vizinhança perdem sua intensidade e o cotidiano metropolitano se estabelece.

Nas próximas páginas procuraremos elucidar como essas transformações se processaram na Penha em meados do século vinte.

\subsection{A Penha na década de 1940: anúncio da metropolização e do fim da vida de bairro.}

\footnotetext{
423 . Idem.

424 . Idem.

${ }^{425}$. RAMOS, A. W., op. cit., 2001, p.154.
} 
Na década de 1940, o processo de urbanização já havia proporcionado intensas mudanças na paisagem local. Apesar de predominar o uso do espaço como área residencial, as atividades econômicas não eram mais as mesmas do começo do século. Tais atividades já se encontravam totalmente inseridas ao contexto da economia paulistana.

Tais mudanças se apresentavam como resultado da intensificação da atividade industrial e da urbanização que se efetuava concomitantemente à Segunda Grande Guerra.

A afirmação da religiosidade penhense já começava a se restringir apenas aos momentos relacionados às datas festivas e a vida de bairro começava a definhar. Voltaremos a essa análise mais adiante.

Vejamos, primeiro, aspectos da realidade econômico-social da Penha ressaltados por alguns autores consultados.

Segundo Aroldo de Azevedo, o que se produzia na Penha no período era transportado para a cidade em bondes, ônibus ou carroças pela Avenida Celso Garcia (principalmente as flores e verduras) e em barcos (cascalhos, areia, tijolos, telhas e alguns produtos agrícolas), pelo rio Tietê e seus afluentes. ${ }^{426}$

A várzea do rio Tietê se apresentava como importante recurso econômico da região, pois além de garantir a água e a fertilidade para a produção agrícola, fornecia areia e argila de boa qualidade para a produção dos tijolos. O rio era importante via de transporte do que era ali produzido.

Os cascalhos eram retirados de alguns afloramentos rochosos do vale do rio Tiquatira, na região do Cangaíba e também eram transportados em barcos.

O que era transportado pelos barcos seguia pelos cursos dos rios Tietê, Tamanduateí até o Porto Geral, na região do Mercado Municipal. Um dos entrevistados nesta pesquisa tratou dessa realidade:

Olaria, alguns fabricantes de barco ali na ponte de Guarulhos. Construíam barcos, batelões, "né"? Ali eles tiravam areia [...] do rio e transportavam nos batelões até, viu, até lá, lá pra, pra ponte Bresser, lá pra ponte das Bandeiras, Aquele lado lá, "né”? É, eles “andavam” por esse rio afora. ${ }^{427}$

Segundo Aroldo de Azevedo ${ }^{428}$, na Penha havia:

- doze fábricas: Fábrica de Artefatos Galite Atlântico (colina da Penha - Rua Dr. João Ribeiro); Fábrica de Giz Brasil (via férrea - Avenida Guarulhos); Fábrica de Santa Teresinha - duas: uma de Papel e outra de celulose - (Aricanduva - Guaiaúna) com 140

\footnotetext{
${ }^{426}$. AZEVEDO, E. A. de, op. cit., 1945, p.79 e 92.

427 . Sr. Fábio.

${ }^{428}$. AZEVEDO, E. A. de, op. cit., 1945, p.93.
} 
operários entre homens e mulheres; Fábrica Técnico-cerâmica - isolantes elétricos - (Vale do Aricanduva) com 197 operários e matéria-prima originária de Mogi das Cruzes e Suzano; União Mecânica - chaves e fechaduras - (encosta do Vale do Aricanduva); Cia Nacional de Anilinas (Baixada do Rio Aricanduva); Fábrica Vulcão - tintas, esmaltes e vernizes - (Vila Matilde) com 60 operários; Fábrica de Produtos Químicos Vale do Paraíba - carbonato de magnésio, cálcio, etc. - (Vila Esperança) com 70 operários, foi fundada em Taubaté e transferida para a Penha e utilizando matéria-prima originária de Taubaté e Itapeva; e outras produtoras de guarda-chuvas, doces, tecidos etc. ${ }^{429}$ As áreas próximas aos rios - planícies aluviais e solos pobres do período terciário (vales e encostas) - e a ferrovia eram aproveitadas para as instalações industriais.

- aproximadamente vinte e três olarias, localizadas à margem do Tietê (matériaprima e transporte fluvial). Utilizavam técnicas rudimentares e a produção era destinada a toda a cidade. Essas olarias já traziam motivos de preocupação: esgotamento de barro e a criação de lagoas que interferiram diretamente no sistema de meandros e regime de cheias do rio Tietê; 430

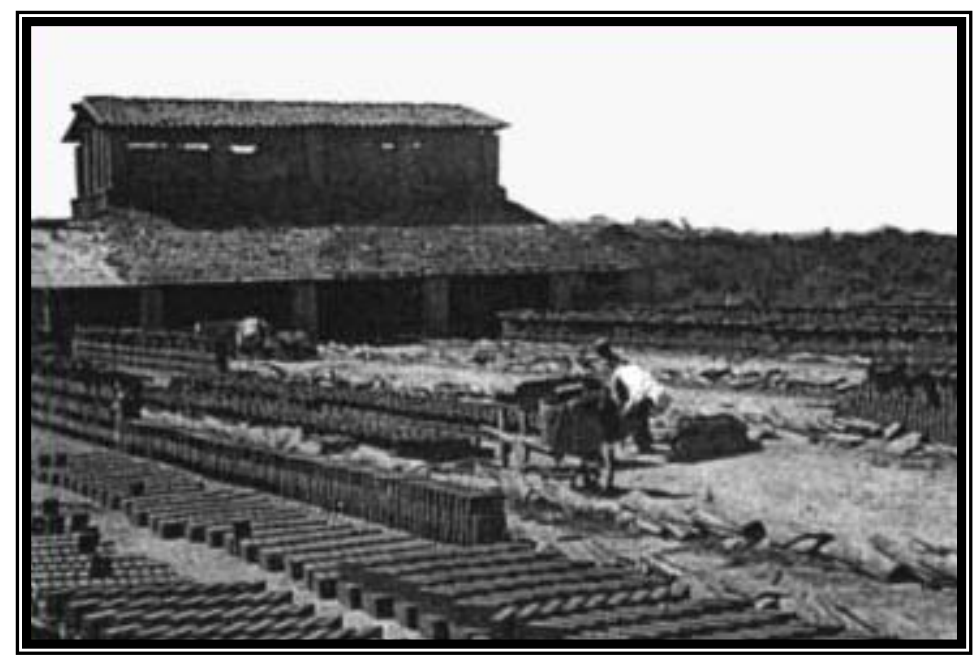

Olaria da década 1940 - Este forno tinha capacidade de 40.000 a 120.000 tijolos de uma vez. (Memorial da Penha de França, acervo digitalizado - Foto: Aroldo de Azevedo)

429 . Ibidem, p.79.

${ }^{430}$. Ibidem, p.79-85. 


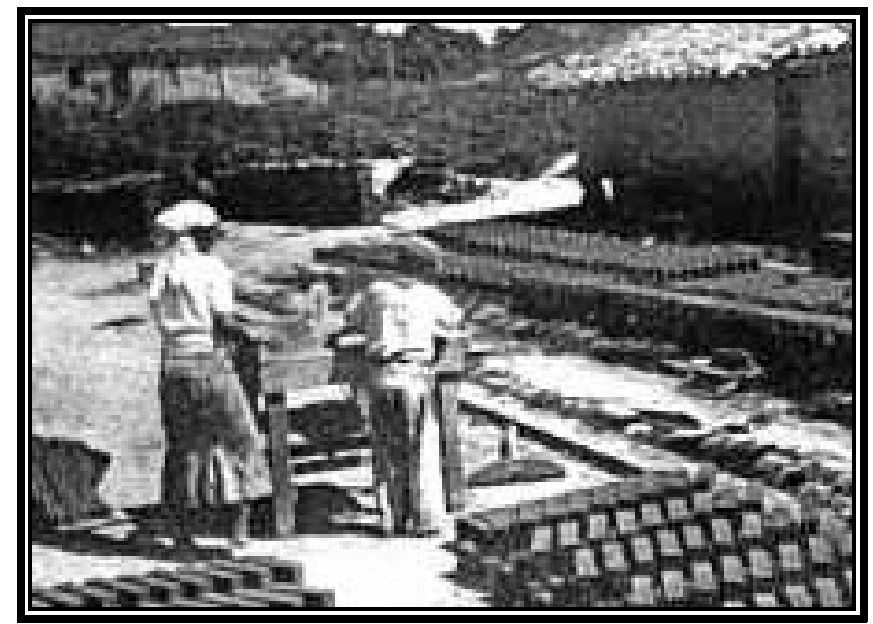

Olaria da década 1940 - Trabalhadores preparando argila. (Memorial da Penha de França, acervo digitalizado - Foto: Aroldo de Azevedo)

Barco de transporte de produtos das olarias e da agricultura penhense na década de 1940. (Memorial da Penha de França, acervo digitalizado - Foto: Aroldo de Azevedo)

- vários portos de

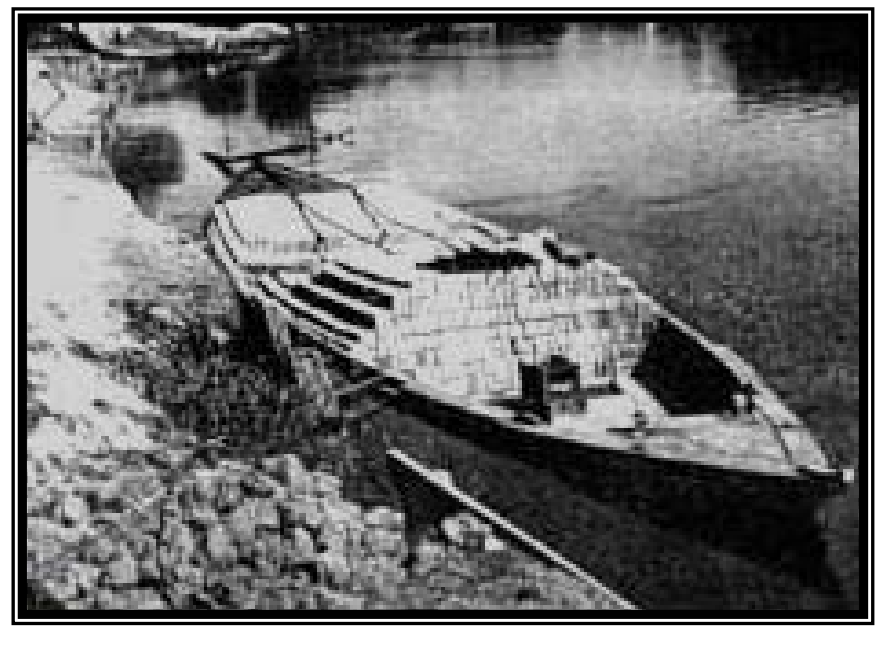

extração de areia, tão prejudicial ao rio quanto as olarias, localizavam-se entre a 'variante de Poá' e o rio Tietê; eram quatro 'portos’ com dragas. A areia era transportada em barcos até as estradas (o mesmo ocorria com os tijolos), e de lá em caminhões até as mais variadas localidades da cidade. Esses tipos de atividades ocorriam em terrenos particulares; $^{431}$

${ }^{431}$. Ibidem, p.85-87. 


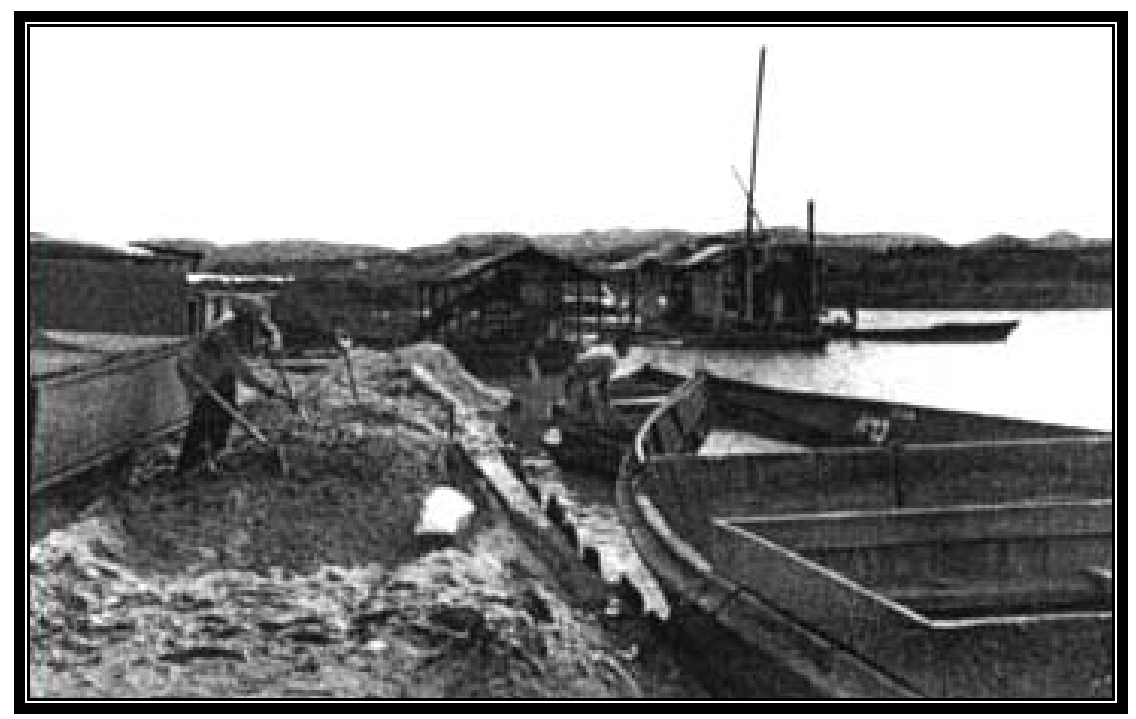

Porto de areia na Penha da década de 1940.

(Memorial da Penha de França, acervo digitalizado - Foto: Aroldo de Azevedo)

- pequena indústria de construção e conserto de barcos, também às margens do Tietê, nas vizinhanças da Avenida Conceição de Guarulhos. Eram indústrias de caráter familiar (portugueses). Tinham sua produção destinada às olarias e à extração de areia, vendiam também para o Vale do Paraíba, interior e, até mesmo, para o Rio de Janeiro; 432

Estaleiro da Penha na década de 1940. (Memorial da Penha de França, acervo digitalizado - Foto: Aroldo de Azevedo)

- as culturas das várzeas,

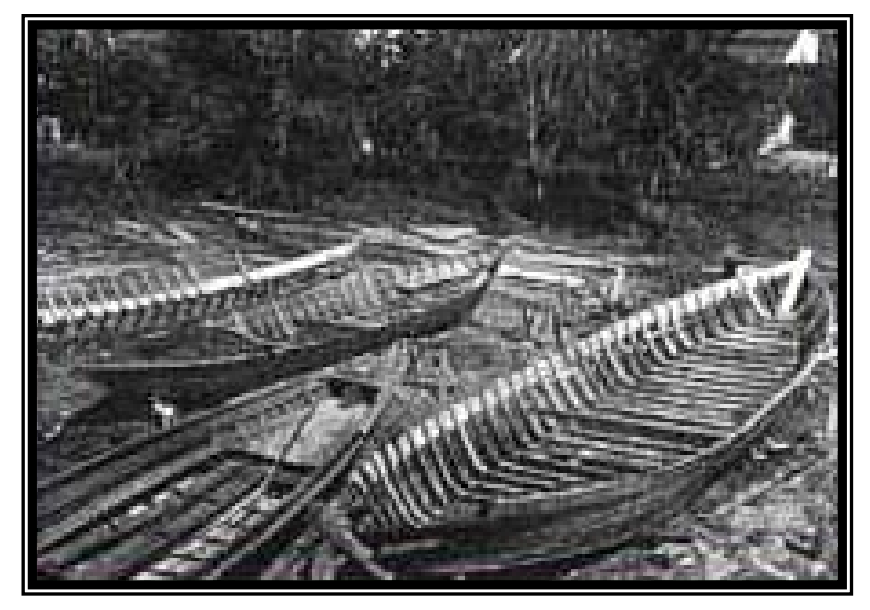

localizadas de preferência em trechos atravessados por cursos d'água e distribuídas por várias outras áreas onde o capital imobiliário ainda não via vantagens. As mais importantes situavam-se nas baixadas quaternárias de alguns afluentes do Tietê (Vale do Tiquatira, Vale do Baixo Aricanduva, baixadas a oeste da Estrada do Cangaíba, no Vale do Guaiaúna e na pequena planície por onde percorria a Estrada Velha da Penha) lembrando que estas áreas não tinham solos melhores que a do terciário, mas a umidade favorecia a abertura de poços e canais de irrigações. Cultivavam-se flores (cravo, dálias,

${ }^{432}$. Ibidem, p.87-89. 
margaridas, copos-de-leite, etc.) e legumes que eram comercializados em feiras e mercados da capital. O Largo do Arouche era um dos maiores receptores dos produtos penhenses. O transporte era feito via bonde (o bonde das três horas da madrugada era destinado aos 'verdureiros'). No Vale do Guaiaúna encontrava-se a 'Hortolândia Paulista', que existia desde 1916, possuía oito alqueires e 40 funcionários e era considerada a principal chácara comercial penhense. ${ }^{433} \mathrm{O}$ centro da cidade era o destino da maior parte da produção de flores.

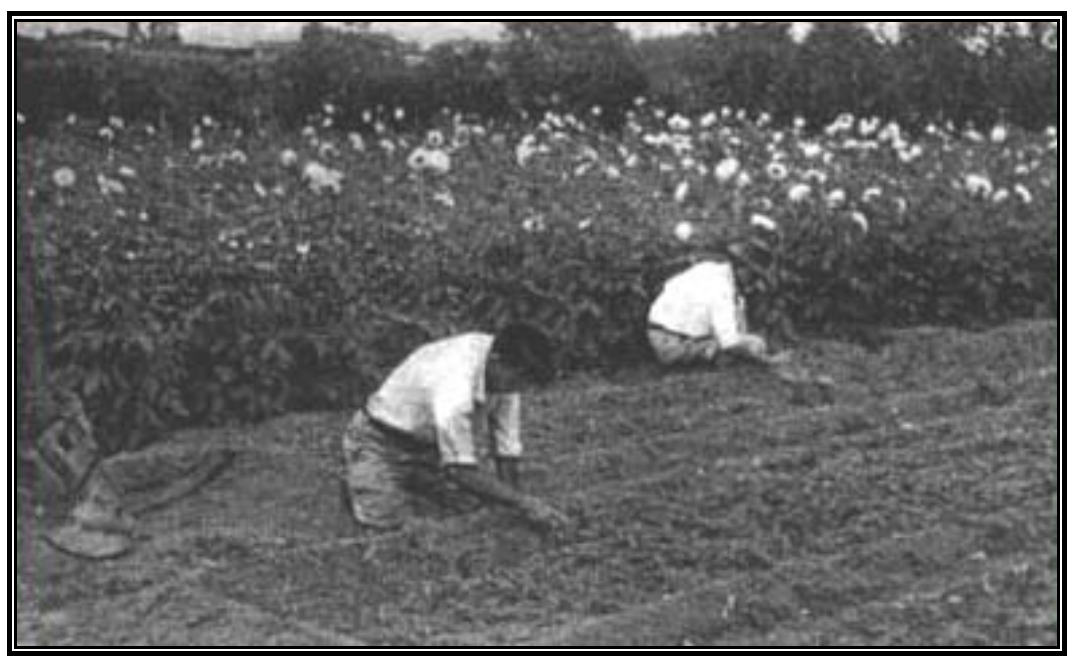

Área de cultivo de flores por família portuguesa no vale do rio Tiquatira em 1941. (Acervo digitalizado do Memorial da Penha de França - Foto: Aroldo de Azevedo)

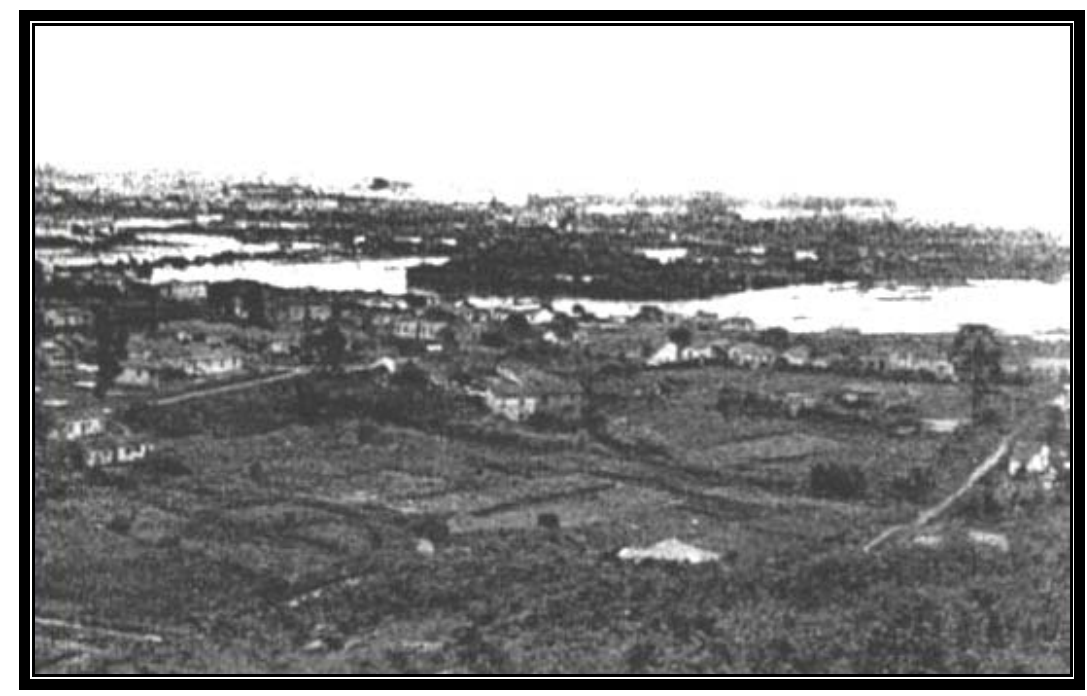

Agricultura no vale do rio Tiquatira em 1941. (Memorial da Penha de França, acervo digitalizado - Foto: Aroldo de Azevedo)

${ }^{433}$. Ibidem, p.89-91. 
Podemos conferir a distribuição espacial destas atividades econômicas no Mapa 6.

Mapa 6 - Atividades econômicas na região da Penha em 1945 - Fonte: Aroldo de Azevedo. ${ }^{434}$

Na década de 1940, o transporte de populares para a cidade também se efetuava por

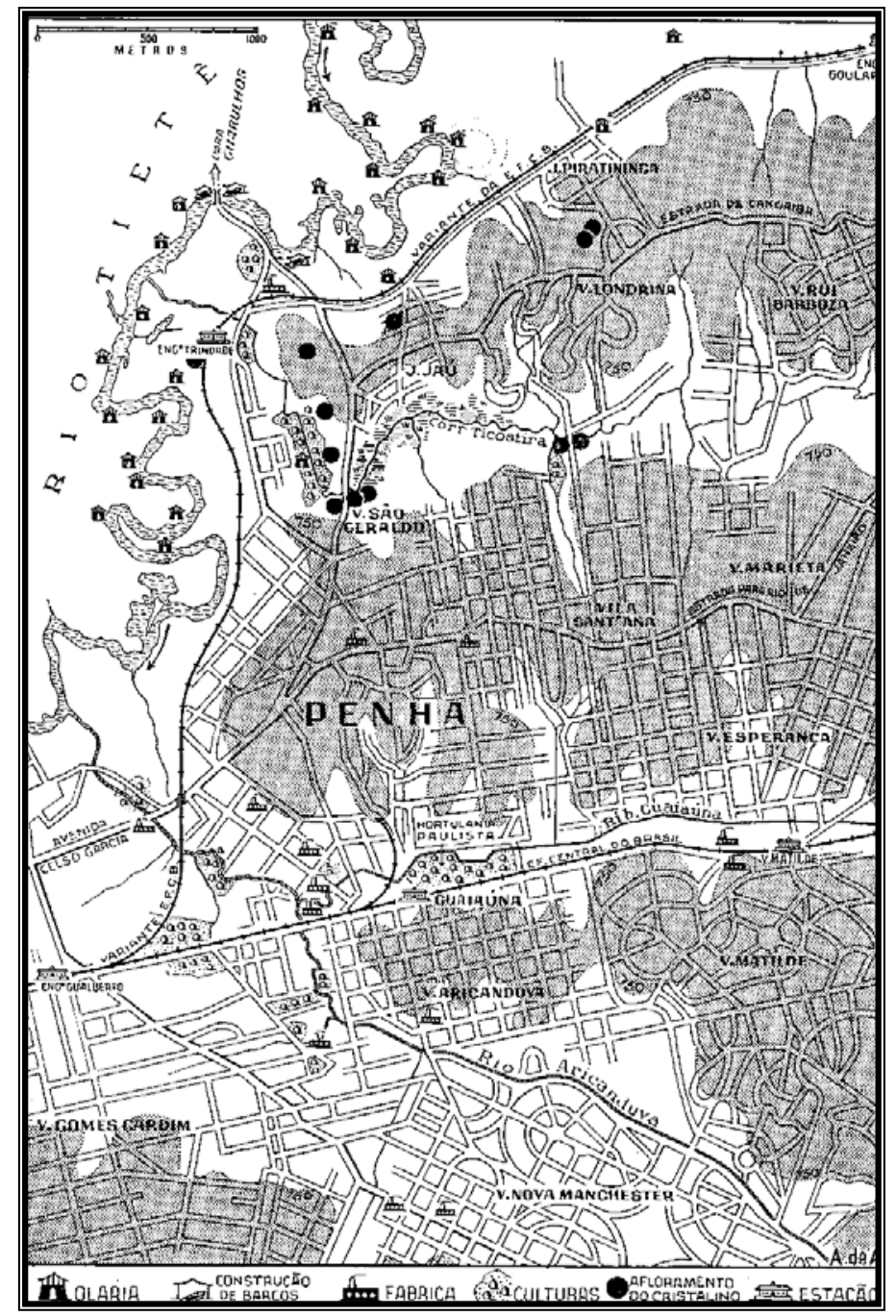
bonde e ônibus. Segundo entrevista, nos anos de 1940:

A condução até a cidade era bonde. Não tinha trem na Penha, o trem na Penha teve há muito tempo, que eu nem cheguei a usar [extinta estação do Ramal Penha]. A estação lá embaixo não chamava-se Penha, era Estação Guaiaúna, era considerado outro bairro. Ninguém descia daqui até lá para pegar o trem, não! Pegava bonde, mesmo porque o trem não chegava até lá [a cidade], chegava até o Brás. Só chegava até a estação do Brás, o pessoal usava bonde né? O bonde levava 45 minutos para chegar até a cidade. Já imaginou? E além do mais, chegava na porteira do Brás e o bonde parava. Muita gente perdeu até emprego, chegava atrasado por causa da porteira do Brás. Daí então começou a aparecer ônibus. Em 1940 a gente tinha os ônibus, mas como houve uma falta de combustível em 1939/40 começou a aparecer caminhões fazendo transportes de passageiros, que nem pau de arara: subia tudo no caminhão até a cidade, era perigoso e chegou um tempo que acabaram proibindo esse tipo de transporte. ${ }^{435}$

Segundo Langenbuch, em meados do século vinte, a ferrovia não conseguiu acompanhar o ritmo de desenvolvimento suburbano por ela gerado. Mesmo com os melhoramentos do serviço de trens suburbanos o problema não se solucionava, pois o fato de serem linhas simples (a mesma para ida e volta) e de também serem utilizadas para a

${ }^{434}$. Ibidem, p.92.

${ }^{435}$. Entrevista Sr. Luís (julho/2006). 
circulação extra-regional, limitava demais os horários de circulação dos trens que atendiam a população. Os poucos trens que passavam pela Penha estavam sempre cheios e atrasados. ${ }^{436}$ Outra queixa era que os trens suburbanos chegavam apenas até o Brás e isso também era um empecilho para quem trabalhava no Centro de São Paulo. ${ }^{437}$

Observamos no depoimento da página anterior que, para o morador da porção central da Penha, a ferrovia já não se apresentava mais com a mesma importância de anos atrás. A ferrovia era para atender moradores de outros áreas mais afastadas.

O interessante é que a localidade conhecida por Estação Guaiaúna, depois Carlos de Campos, distava não mais que um quilometro e meio do centro da Penha (como podemos observar no Mapa 6 de Aroldo de Azevedo). Podemos observar em outros depoimentos que a Guaiaúna não era considerada Penha e que, para os moradores, penhenses eram considerados apenas os que viviam no antigo núcleo central (manifestação do bairrismo dos moradores da localidade).

Langenbuch também afirma que apesar da Penha ser atingida por uma via férrea, o fato da porção central da localidade se encontrar no "sopé da colina” exigia uma penosa caminhada através de ladeiras nada favoráveis. ${ }^{438}$

Reclamar dos transportes na década de 1940 era comum. As entrevistas realizadas revelam o quanto a localidade ainda se encontrava isolada. Segundo Sr. Clara, que se mudou da Mooca para a Penha com vinte e dois anos, em 1947:

Quando eu cheguei aqui era longe, o bonde levava mais de uma hora para chegar [...] Na Penha tudo que eu precisava no começo não tinha [a senhora Clara era costureira], tinha uma loja só, era caro, não me lembro que loja era, [...] era muito isolado [...] pra dizer a verdade, eu não gostava da Penha, por um motivo: onde eu morava em cinco minutos eu estava na cidade, então era um lugar movimentado, tinha colégio, tinha tanta coisa e quando eu vim aqui, era interior, então lá era tudo calçado, aqui tudo barro, quer dizer que me deu uma decepção, mas fui me acostumando, acostumando, que agora adoro, não troco por nada. ${ }^{439}$

O crescimento da população penhense também merece destaque. Na década de 1920 eram 6.080 habitantes e em 1940 passaram a ser 56.709 habitantes. ${ }^{440}$ Já no final da década de 1940, a população começava a sofrer com os problemas característicos das grandes cidades: os engarrafamentos em suas estreitas vias eram constantes, a falta de saneamento e de água também, o transporte público não era suficiente para a demanda, faltava habitação, entre outros.

\footnotetext{
436 . LANGENBUCH, J. R., op. cit., 1971, p.190.

${ }^{437}$. Sr. Alípio: “E poucos procuravam, porque o número de trens não era assim como é o metrô hoje. De 3 em 3 minutos."

438 . LANGENBUCH, J. R., op. cit., 1971, p.191.

439 . Entrevista com Sra . Clara (julho/2006).

${ }^{440}$. LANGENBUCH, J. R., op. cit., 1971, p.170.
} 
Na década de 1940, a condição de subcentro se fortalecia e ao redor da igreja o equipamento comercial e de serviços se diversificava. As lojas de artigos religiosos ainda predominavam na localidade: eram aproximadamente 15 lojas que vendiam estampas, medalhas, terços, velas, imagens e mais uma porção de parafernálias destinadas ao bom devoto $^{441}$. Essas lojas estavam concentradas principalmente na Rua da Penha (da Praça Oito de Setembro à Igreja Nossa Senhora da Penha).

Na época, além desse tipo de comércio, havia alguns poucos armarinhos, lojas de sapatos, de ferragens, armazéns e mercearias, entre outros ${ }^{442}$. Encontrava-se também abundância de bares, padarias e confeitarias ${ }^{443}$, ateliês de fotografia e inúmeras barracas e tabuleiros (onde se vendia frutas, refrescos e outras quinquilharias) que se espalhavam por toda a localidade e davam certo ar de feira-livre à Penha. ${ }^{444}$

As lojas se misturavam às construções destinadas ao acolhimento dos religiosos, à prestação de serviços, ao poder público e às moradias.

No final da década de 1940, aumentou a circulação de transeuntes pelo subcentro e assim começou a incrementar e diversificar o comércio penhense. A circulação teve esse aumento graças aos que vinham das localidades mais a leste e dos diversos loteamentos que apareciam na região e que dependiam no vai-e-vem para a cidade dos baldeamentos ônibus-ônibus e ônibus-bonde que se faziam na Penha.

Segundo Sr. Luís, na década de 1940,

Os ônibus da periferia da Penha não iam até a cidade, eles vinham até a Penha, de Guarulhos vinha para a Penha, de São Miguel vinha para a Penha. A gente tinha que pegar outra condução, bonde também, para a cidade. Depois que começaram a por essas linhas diretas, também foi progredindo muito por aí, outros bairros foram aparecendo, e começou Guarulhos até a cidade, passando pela Penha, mas eles iam direto. ${ }^{445}$

Segundo Sr. Fábio,

${ }^{441}$. Sr. Fábio. Segundo o entrevistado, “casas de velas tinham bastante, 'né’? Por exemplo, ali na esquina, subindo aqui, (Avenida Penha de França com a Praça 8 de Setembro) hoje é um, uma casa de móveis, ali, era uma casa de velas muito antiga. Tanto é que aquele prédio era tudo dele, chamava-se 'Pozzoli'. Não sei, acho que já morreu, também... morreram todos e até o largo da igreja, tinha umas cinco ou seis casas de velas.” O sr. Pacha completa: “eram todos comerciantes do comércio de varejo. Tudo se desenvolvia em volta, em torno da igreja [...] eram de italianos e portugueses.”

${ }^{442}$. Sr. Fábio. Segundo o entrevistado, “aqui, por exemplo nós tínhamos o armazém do 'Rossi'. No “Rossi” tinha de tudo e tínhamos aqui a pizzaria dele, também, ali onde o Caipira fechou... Ali era a pizzaria dele. Vinham pessoas da cidade pra comer pizza aqui da Penha. Era muito bom! Mas não sentíamos muita falta de sair daqui pra ir pra cidade comprar alguma coisa, não. A não ser roupas..."

${ }^{443}$. Sr. Fábio. Segundo o estrenvitado “aqui na Rua da Penha, por exemplo, tinha cinco ou seis padarias, confeitarias. Tinha a confeitaria Penha-Teatro, a confeitaria Nossa Senhora Aparecida, confeitaria Modelo, confeitaria Cruzeiro, confeitaria Brasileira e mais uma outra confeitaria, mais uma outra padaria e confeitaria que eu não me lembro o nome. Tudo, uma pegada à outra."

444 . AZEVEDO, E. A. de, op. cit. p.70-71.

445 . Sr. Luís. 
Aqui na Penha. Eu não me lembro a época que foi, que iniciou-se, mas tinha um ônibus que saía aqui do, vinha até aqui na Penha, era o ponto final. Ia para Guarulhos, outro ia para a Vila Esperança. Depois começou a "vim” o São Miguel. Eram ônibus de, muito demorado, não era assim como existe hoje, ônibus constantes, passa um, já vem outro. Eu lembro que tinha horário, "né"? Era só esses bairros: Guarulhos, São Miguel... Guarulhos, São Miguel... Eu não me lembro se tivesse mais não. Não me lembro. Pra você ir, por exemplo para Itaquaquecetuba, Poá, era de trem. ${ }^{446}$

No entanto, na década de 1940, a religiosidade ainda continuava como referência na localidade. Segundo o Sr. Alípio, a religião,

[...] era muito forte, bem mais do que hoje. Naquela época, as romarias que tinham na Penha, as procissões, eram procissões! Se encontravam para fazer percursos, travessias, quando estava chegando o pessoal da cidade tinha gente saindo, era muito grande, era muito concorrido. E a gente é tudo de São Paulo. Eu me lembro de 1940, eu tinha 7 anos, mas eu tenho fotografias minhas de cabelo comprido, encaracolado, vestido de anjo, acompanhando procissão com 3, 5, 10 anos de idade, eu tenho recordações até hoje. ${ }^{447}$

Com o aumento dos loteamentos na região, o desmembramento da paróquia de

Nossa Senhora da Penha continuava. No ano de 1940, surgiram as paróquias de Vila Esperança, de São José do Maranhão e de Vila São Geraldo-São Luiz Gonzaga. A redução do território da paróquia Penha chegou a tal ponto que em seis de fevereiro de 1941, “foi vendido o automóvel da paróquia por não ser mais necessário para os serviços paroquiais." 448

As tentativas de aproximação da Igreja penhense com o operariado obrigavam-na a tentar se adaptar aos ritmos impostos pela industrialização. Tanto que em dois de abril de 1942, em uma Quinta-feira Santa, ocorreu a "comunhão geral dos homens. Foi necessário celebrar-se uma missa às 5hs, pois os operários precisavam ir ao trabalho. Comungaram 710 homens." 449

A proletarização dos hábitos começa a provocar mudanças na forma de viver da população penhense e a Igreja tenta acompanhar essas mudanças.

O que ocorreu nada mais foi do que a tentativa de adaptação da Igreja às novas relações sociais que se estabeleciam.

Para a manutenção de sua hegemonia, a Igreja passou acompanhar o ritmo determinado pela necessidade da população, isto é, o ritmo da produção industrial.

Não podemos afirmar que essa estratégia, de acompanhar o ritmo da indústria, se fazia realmente válida; mesmo tentando se adaptar ao tempo do trabalho, os resultados

\footnotetext{
${ }^{446}$. Sr. Fábio,

${ }^{447}$. Sr. Alípio.

${ }^{448}$. Cf. Livro Tombo da Freguesia de Nossa Senhora da Penha. - Livro Códice 8-3-12, aberto em 1940, p.17.

${ }^{449}$. Ibidem, p.24.
} 
das ações da Igreja penhense eram quase que inócuos e a população cada vez mais se afastava da igreja da Penha. Em 1942,

se fez a benção das casas no tempo da Páscoa. O resultado não foi o esperado, porque maioria das casas faltou o chefe, que estava em trabalho. É cousa difícil entrar em contato com os homens pois cedo vão ao trabalho, nalguma fabrica ou oficina na cidade, e só voltam á noite. O circulo operário fundado com a intenção de aproximar mais os homens da religião não surtiu efeito. O número de sócios é bastante grande, porém eles só se lembram do circulo pra pedir auxílios. ${ }^{450}$

Em maio de 1944, segundo a opinião dos que assistiram à procissão de corpos Christi, a freqüência foi inferior à dos anos anteriores. ${ }^{451}$

Em junho do mesmo ano,

[...] apesar de ser semana comemorativa do centenário do apostulado da oração, a freguesia tem sido, tanto nas missas como nas pregações, muito fraca e deficiente [...] O mez de Cor. De Jesus foi fraquíssimo. As comunhões em menos número que em outros mezes. Por que seria? Indícios do tempo? Nem sequer a devoção ao S. Coração é capaz de aquecer a alma fria, indiferente do povo, que dança no abismo. ${ }^{452}$

E em outubro, "acabamos mais um ano, há de se deplorar uma diminuição da freqüência aos sacramentos” ${ }^{453}$. Isso é atribuído à dificuldade de deslocamento dos operários até o trabalho, em geral muito longe da Penha. As pessoas saíam de madrugada e voltavam tarde da noite para casa.

Por mais esforço que a Igreja penhense demonstrasse na luta pela preservação das tradições locais, o tempo do trabalho tornava-se implacável na forma de viver da população. No âmbito das mudanças impostas pelos processos de urbanização e industrialização, a Penha se apresentava mais como bairro dormitório.

A proletarização da Penha, junto à crise econômica do tempo da Segunda Grande Guerra, ampliava a pobreza na localidade. Os tempos eram difíceis e na fila das doações de dezembro de 1943, houve distribuição de gêneros e corte de roupas para os pobres: “é triste constatar que até as pessoas mais ou menos remediadas, entraram na fila dos pobres para receber esmolas. Entre essas, havia pessoas dadas como pobres envergonhados."454

Sr. Alípio reforça a situação de pobreza que a maior parte da população penhense do período passava. Quando perguntado sobre o que havia marcado sua vida nos anos de 1940 ele respondeu categórico:

Era mais a miséria mesmo, a falta de tudo, meu pai já dizia que se me fizeram voltar pra aqueles anos, eu não quero não, porque o que eu passei de miséria com vocês, com 1 tostão você pegava condução pra ir pra cidade ou um pacote de

${ }^{450}$. Cf. Livro Tombo da Freguesia de Nossa Senhora da Penha. - Livro Códice 8-3-12, aberto em 1940, p.28.

451 . Ibidem, p.39.

452 . Idem, p.39.

453 . Ibidem, p. 45.

${ }^{454}$. Ibidem, p.35. 
bala, mas ninguém tinha 1 tostão. Não tinha população com dinheiro, sempre teve uma ou duas famílias, mas a população assim não. A maioria era tudo miserável. [...] No centro da Penha, em volta, tinha a família do Dr. Jacinto, que era médico. Tinha a família Mello que era tradicional na Penha, tinha uma porção de famílias de tradição que tinha um pouquinho mais de condições, a maioria era como meu pai, por exemplo, era motorneiro de bonde, fez uma casinha com sacrifício, minha mãe trabalhando, cinco filhos, tudo com dificuldade, mas meu pai tinha até um pouco de revolta. Teve uma festa por exemplo, na Light, [...] e levou um amigo nosso e nunca mais ligou porque a diferenciação que faziam do operário para o chefe era do dia pra noite, então dava uma boneca pra um e uma coisinha de pano para o filho do operário, era muito complicado, a diferença era muito grande. $^{455}$

A Igreja penhense tentava compreender e se adaptar as novas formas e necessidades do viver da população que se proletarizava na localidade. Os conflitos ideológicos que envolviam religiões e concepções políticas diferentes se ampliavam e, em relação aos anos anteriores, tais conflitos deixavam bem mais claro que se tratava, mesmo que maquiadas pelo teor religioso do discurso, de um embate entre classes na localidade.

Vamos verificar alguns dos diversos exemplos destes conflitos que se efetuaram ao longo da década de 1940 dividindo-os em dois blocos, os inter-religiosos e aqueles de cunho político, faremos uma breve análise de cada um deles e depois, como são complementares, tentaremos uma análise conjunta. As transcrições também revelam muito das dificuldades que a população penhense enfrentava no período em análise.

Quanto aos conflitos entre religiões diferentes, temos de relevante quatro citações:

Em novembro de 1942, Dia das Almas, houve procissão para o cemitério,

[...] lá na capela funcionou também o Exército da Salvação logo depois da retirada dos Padres. Até as $11 \mathrm{hrs}$, uns moços puzeram-se a rezar o terço com o povo para impedir a profanação desses negros boçaes das 2 hrs da tarde em diante teve um padre lá rezando com o povo. Houve algum atrito. É uma absurdo permitir que um punhado de ignorantes venha obter licença para ofender com alusões o sentimento católico da população. Si Deus quizer no próximo ano se tomará outras providências. ${ }^{456}$

Em maio de 1945,

Nos dias 18, 19 e 21 o vigário benzeu e colocou o Sr. Crucificado [imagem] em diversos estabelecimentos: numa fábrica de parafusos e em 10 padarias. Duas se recusaram, alegando crença protestante e uma por ter um empregado rubro!! Cristo Senhor entrou nas seguintes casas: Padarias e confeitarias: NS da Penha, Sorriso, Brasileira, Cruzeiro, Modelo, Marquesa, Penha-Teatro, N. Sr Aparecida, Estrela Leal Ltda, Aparecida e escola de corte e costura Sto. Afonso. ${ }^{457}$

Dezembro de 1947,

[...] Tem causado indignação o novo método de propaganda protestante, que vem fazendo o templo metodista em frente da igreja do Rosário. Os adeptos dessa seita instalaram um alto-falante, voltado justamente para as duas igrejas: Matriz e Rosário, principalmente aos domingos, na hora em que os peregrinos se dirigem para a igreja. [...] começam os tais a cantar e a pregar. Fez-se reclamações às

455 . Sr. Alípio.

${ }^{456}$. Cf. Livro Tombo da Freguesia de Nossa Senhora da Penha. - Livro Códice 8-3-12, aberto em 1940, p.27$\mathrm{v}$.

${ }^{457}$. Ibidem, p.49. 
autoridades. O vigário, então , mandou instalar também alto-falante na torre da igreja do Rosário. Sem atacar, nem lastimar, procura-se neutralizar o efeito da propaganda, com devoções, cânticos e rezas. Vamos ver, em que vai dar tudo isso. O povo tem comparecido em massa,enquanto que no templo metodista Em junho de 1948, apenas umas dez pessôas fazem o seu barulho desafinado. ${ }^{458}$

[...] no mêz de janeiro a igreja Matriz e do Rosário foram visitados por ladrões. Levaram pequenas quantias dos cofres menores, obrigando o vigário a fazer uma revisão na campainha de alarme. A propaganda protestante diminuiu de intensidade. Queira Deus, cesse. ${ }^{459}$

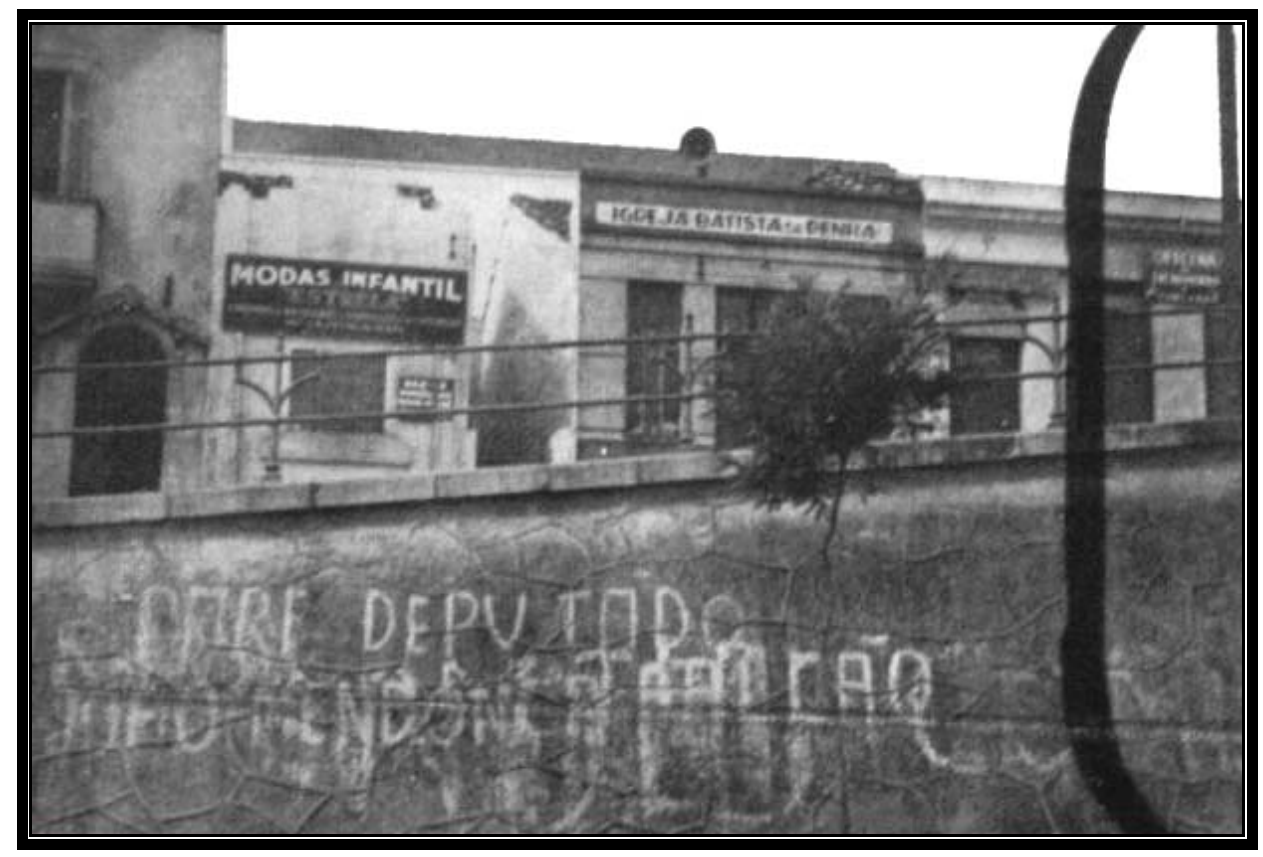

Igreja Batista da Penha em 1950 - No Largo do Rosário, em frente a Igreja de Nossa Senhora do Rosário dos Homens pretos (Memorial da Penha de França, acervo digitalizado)

Segundo Rosendahl, a religião, quando examinada em um contexto geográfico relacionado á apropriação de determinados segmentos do espaço, reivindica áreas de controle territorial. Essa territorialidade representa o resultado do conjunto das práticas desenvolvidas por instituições ou grupos de controle ideológico do espaço. Assim, essa territorialidade reivindicada é a garantia tanto da expansão, quanto da manutenção hierárquica estabelecida pela religião. ${ }^{460}$

Rosendahl ainda nos alerta que "um dado lugar pode ser usado como um território em um dado tempo e não mais em outro período” e define a existência de três tipos comportamentais de territorialidade possíveis de serem associadas à religião: “por coexistência pacífica; por instabilidade e competição, e; por intolerância e exclusão."461

\footnotetext{
${ }^{458}$. Ibidem, p.80.

${ }^{459}$. Ibidem, p.81.

${ }^{460}$. ROSENDAHL, Zeny. Espaço e religião: uma abordagem geográfica. Rio de Janeiro: URJ-NEPEC, ${ }^{461}$. Idem. 1996, p.59-61.
} 
Segundo a autora, no primeiro caso, a “coexistência pacífica representa um equilíbrio, acompanhado por sentimentos mútuos de respeito, indiferença ou de antipatia.” A disposição de tolerância religiosa permite que num mesmo território as pessoas tenham filiação religiosa pluralista e em alguns casos até resultam em sincretismo entre os diversos segmentos religiosos. ${ }^{462}$

No segundo caso, “por instabilidade e competição”, Rosendahl afirma que a

[...] interação entre sistemas religiosos é a competição e instabilidade, na qual um dos sistemas é caracterizado pela instabilidade. A conversão por contato e a atividade missionária estão fortemente associados a este tipo [...] A organização e o esforço desempenhado pelos movimentos missionários tendem a criar um padrão de conversão escasso, em torno de conceituações centrais. ${ }^{463}$

Neste caso, aparecem embates no sentido de difundir as ideologias das religiões envolvidas, onde a resistência e a competição, permeadas pela luta pela conversão de fiéis, acontecem cotidianamente pelo espaço. Acreditamos que esse é o caso que podemos observar nas situações expostas parágrafos atrás.

O terceiro caso, “por intolerância e exclusão.”, não observado na localidade, proporciona um comportamento exclusivista que resulta em ódio e violência, onde a questão territorial torna-se alvo de pressão política e envolve a ação do Estado.

Como vimos, outras religiões também se desenvolviam na Penha. No entanto, o protestantismo, assim como aconteceu com o catolicismo (ambos de mesma origem e com a mesma estratégia de conquista), também tem como prática a luta pelo expansão e pelo controle territorial.

Para a Igreja penhense e o conservadorismo dos grupos dominantes responsáveis pela história da organização social da localidade, perder ou até dividir a territorialidade conquistada era inaceitável e não podia gerar outra coisa que não fosse conflito.

Na Penha, a luta pela manutenção da antiga organização social nada mais é que a luta pela preservação do que se conquistou e se organizou em uma estrutura de classe estabelecida no bojo das continuidades históricas locais.

Para concluir, o emprego de termos como "negros boçaes" não pode passar desapercebido e como simples referência racial ou apenas identificação subjetiva de um preconceito. O termo “negros boçaes” permite correlacionar o protestantismo penhense aos mais pobres da localidade, aos que se sentiam excluídos do direito de usufruto do espaço e que passam a se manifestar na luta social pela territorialidade. Aceitar a livre

\footnotetext{
462 . Idem.

463 . Idem.
} 
manifestação dos protestantes é, antes de reconhecer um direito, reconhecer o enfraquecimento do conservadorismo e das antigas tradições.

Veremos esse quadro se repetir no item seguinte, quando em 1950 temos a chegada de judeus e nordestinos.

Vejamos, agora, manifestações da Igreja Católica revelando conflitos com “comunistas”.

Em outubro de 1945,

Vae se esboçando a luta por princípios: por Cristo ou contra Cristo; Igreja ou comunismo. [...] O comício comunista estava marcado para a pr. N.Sra da penha, 20hs! Foi feito no largo do Rosário. A mesma hora que fizemos, na igreja a procissão interna do Ismo. A freqüência ao comício, segundo testemunhas foi pequena, apenas um terço do pequeno largo foi tomado. Foi pouca cousa mesmo, considerando-se a população da Penha, foi nulo, considerando-se a que o comício era para a população do Braz até o fim da paróquia de S. Luiz. Apesar de tudo, foi sempre um comício comunista i. é, a pregação da solução materialista dos problemas da vida. ${ }^{464}$

Em novembro de 1945,

Intensifica-se a campanha eleitoral. A LEC não preencheu a finalidade. [...] É um pedir de informação por parte do eleitorado que não acaba mais. Infelizmente começamos otimamente e vamos atualmente vegetando, enquanto o comunismo fez propaganda, toma posição e cresce de prestígio. A LEC abandonou, ou melhor nunca deu importância aos comícios nas ruas e bairros. E, é importante. As eleições dirão quanto errados andávamos.”[...] "É intensa a procura de cédulas nos postos da LEC local. Primeira pergunta é regularmente qual o candidato da Liga? Resposta: Não tem! Vote em quem quizer! Acentua-se a procura por cédulas Gaspar e Getúlio! Hoje à noite teve lugar a apregoada sabatina entre o P. Saboia I.J. e um representante do partido comunista por estações radiofônicas. Imensa expectativa.... Não satisfez! O antagonista do padre não estava a altura. Não respondeu às perguntas, fugiu a elas! Infelizmente, a linguagem do padre era muito elevada e a correspondência com as fugas do adversário foi demasiada. A impressão deixada no povo não foi favorável! ${ }^{465}$

Dois de dezembro de 1945,

Eleições! Desde as primeiras horas, filas enormes rumo aos postos eleitoraes. Balburdia, confusão, sabotagem, desordem, eis aí o que foi as eleições! Um atestado contristador de organização! Votou quem tinha vontade de enfrentar todas as situações e paciência de esperar 4, 5 e mais horas. Para os padres não faltaram piadas dos comunistas. A votação que devia encerrar-se ás 6 hs da tarde (?) noite a dentro e em algum logar foi até 4 hs da madrugada do dia 3! Tudo por causa da boa organização.

Dia três,

Começam as surpresas na apuração: o partido trabalhista está na frente. Os comunistas tem conseguido boa votação." Dia oito, "a apuração da eleições revela grande votação p. o comunismo, aqui na Penha. Na rua, recrudesce a piada ao padre. Por toda a parte, queixa contra a LEC, alegando que ela é o fator principal da grande vantagem do Dutra sobre o Brigadeiro [Eduardo Gomes]. Assim fosse e, ao menos apanharia com causa. Mas, não fazer 'orientação' e apanhar assim mesmo... A votação ao Dutra surpreendeu. Injustamente se atribue

${ }^{464}$. Cf. Livro Tombo da Freguesia de Nossa Senhora da Penha. - Livro Códice 8-3-12, aberto em 1940, p.50.

${ }^{465}$. Ibidem, p.52. 
partidarismo à LEC. É cousa que de fato não se pode culpar a LEC ou ao clero em geral: a de opressão nos eleitores. ${ }^{466}$

Vinte e sete e de dezembro de 1945, “Irrompeu uma greve dos operários da Light. Pouco movimento no bairro, pois é quase impossível a comunicação com o centro. "467

Dezembro de 1945,

Tiveram os comunistas também grande votação no distrito da Penha. Seja dito porém que o distrito da Penha é uma s 6 vezes maior que a paróquia da Penha, compreendendo umas 6 paróquias. É ilógico por isso, deduzir-se da votação muito pronunciada do comunismo na paróquia ${ }^{468}$

Em março de 1946,

[...] as chuvas prejudicaram muito o movimento. A freqüência às pregações foi fraca e o resultado foi pequeno. A maior dificuldade está no congestionamento do tráfico. O povo volta tarde e cançado par suas casas [...] Além disseo, as filas de pão, assucar, etc. O povo esta desesperado e descontente. O pior é que o comunismo explora a situação para fazer suas propagandas. ${ }^{469}$

Em abril do mesmo ano,

Abril: semana de estudo social feito pelas congregações da Penha. Objetivo: [...] orientar os moços no serviço de investigações e pesquizas a respeito das atividades subversivas de comunistas. Como resultado, vários moços conseguiram descobrir vários planos de greves desordenadas que os tais pregadores da democracia tencionavam fazer. ${ }^{470}$

Em junho, o padre Sabóia,

Pede proteção para as pessoas sofridas da Penha que suportam tantos males e necessidades: filas de bonds, filas de ônibus, fila de pão, etc. [...] O padre Sabóia, "dirigente eclesiástico do Serviço de Ação Social, organizou várias concentrações nas paróquias afim de orientar o povo contra a propaganda comunista que esta explorando a situação angustiosa, por que passa o paiz. Para fins de sua propaganda nefasta, os assuntos prediletos desses agentes de Moscou são: o câmbio negro, falta de habitações, filas de pão, etc. A concentração teve bom resultado. Esperava-se maior numero de operários. O grande mal é o congestionamento de trafego, que impede o pessoal de chegar cedo ás suas casas. Este é o mal no 1 do Bairro da Penha [...]

Dezembro de 1946,

[...] a reunião da Liga EC para orientação do eleitorado católico aconteceu tarde. Talvez não se poderá fazer muito. Os comunistas trabalham constante e já conseguiram muito. Penha, aos poucos, se transforma num mundo comunista. O congestionamento e o trafego na avenida Celso Garcia e o estado miserável das ruas são os melhores propagandistas do comunismo! O povo vê esse movimento como uma oposição ou um protesto contra o governo!

Assim como pudemos observar na análise dos conflitos inter-religiosos e das manifestações anticomunistas que se desenrolaram na Penha também tangenciam a luta pela manutenção das práticas sociais conservadoras na localidade.

Diferente do conflito entre católicos e protestantes, o conflito entre católicos e “comunistas" se apresenta muito mais direto, aberto e intenso. A Igreja, novamente representa a manutenção das forças políticas tradicionais. A estratégia de luta contra o

466 . Idem.

467 . Ibidem, p.53.

468. Ibidem, p.53-v

469 . Ibidem, p.56. 
comunismo é muito mais envolvente que a luta contra os protestantes, pois a ameaça da perda material é até muito mais assustadora que a da perda espiritual. Assim, representadas por integrantes das famílias tradicionais, as irmandades católicas se vêem integradas diretamente no confronto.

Neste tipo de conflito, acreditamos que os grupos eram mais coesos, pois eles não se estabeleciam a partir de um discurso de conquista territorial em prol de uma fé e da posterior salvação individual que isso acarretaria. Estabelecia-se pelo próprio caráter do que estava em jogo, a defesa da propriedade, ou melhor, da manutenção dos privilégios das famílias tradicionais penhenses.

Os embates entre catolicismo e comunismo da década de 1940 se diferenciam dos conflitos da década de 1930 pela própria condição histórica da localidade e da cidade. O processo de urbanização avançava e, no final dos anos quarenta, já não restavam mais dúvida do que significaria tais mudanças para a vida da população local. Como vimos nas últimas transcrições, o que reforçava o discurso comunista era a própria condição de pobreza da população e as dificuldades que a urbanização trouxe à localidade: as filas, o trânsito, a penúria durante os anos de guerra...

Podemos observar ainda que o discurso anticomunista da Igreja era mais de convencimento que de confronto e não convencia, e a rejeição ao que ela pregava era uma realidade entre a população sofrida. A idéia de que a Igreja católica penhense falava para os pobres o discurso dos ricos já havia se arraigado, como podemos observar na seguinte entrevista:

\begin{abstract}
Nos anos 50 ainda tinha alguns conflitos da Igreja com a política, mas não assim. O pessoal falava, dava opiniões, convencia o povo a votar ou não votar nesse ou naquele. A Igreja sempre foi dos pobres, mas quem tinha dinheiro mandava na Igreja, atendia mais a quem tinha dinheiro. Nos anos 50 eu acho que era acentuado porque as grandes famílias de tradição da Igreja tinham fluxo dentro da Igreja. ${ }^{471}$
\end{abstract}

Também não acreditamos que o discurso comunista na localidade fosse forte: nas entrevistas feitas não aparecem referências aos mesmos e os embates com a Igreja são ignorados. O que nos interessa mesmo é que tais informações revelam-nos o quanto o que vinha de fora já havia se estabelecido na localidade.

O enfraquecimento da hegemonia da Igreja atesta o avanço da sociedade urbana e o enfraquecimento das relações tradicionais na localidade.

O fato é que o viver na cidade é uma condição, ou melhor, é uma experiência que se estabelece a partir de múltiplos significados representados por diferentes grupos e

${ }^{470}$. Ibidem, p.57. 
pessoas que compartilham de uma mesma realidade. Assim, os problemas da localidade eram compartilhados por todos e não apenas pelos menos ou mais afortunados. Os problemas até aqui delineados eram apenas reflexos do que acontecia na cidade como um todo. São Paulo dos anos de 1950 estava se consolidando como metrópole.

\section{$\underline{3.30 \text { fim da vida de bairro }}$}

Na década 1950, o crescimento da população da Penha e arredores seguia o ritmo do crescimento população paulistana e passou dos 43.991 habitantes em 1940 para 82.814 habitantes em 1950, chegando a 149.179 habitantes em $1960 .^{472}$ No mesmo período, a cidade de São Paulo e arredores passavam de 1.580.302 habitantes em 1940 para 2.6688.90 em 1950, chegando a 4.862.485 habitantes em1960.

Na década de 1940, as velhas tradições culturais da localidade, estabelecidas durante a constituição o bairro rural, que se mantiveram, apesar das mudanças ocorridas com o avanço da urbanização e a transformação da Penha em subúrbio, entram em franca decadência. Exatamente desta decadência, somada ao fim do isolamento físico e do uso rural do solo da localidade, decorre a integração da Penha à cidade de São Paulo - agora como bairro paulistano propriamente - para, na década de 1950, deixar de se comportar como unidade, isto é, perder, gradativamente sua identidade para transformar-se em fragmento da metrópole.

Antes de entendermos como se deu esse processo, vamos nos ater um pouco mais ao que significou o processo de metropolização paulistano.

Segundo Langenbuch, o processo de metropolização da cidade de São Paulo vai se distinguir por dois momentos: o início da metropolização, entre 1915 e 1940, quando os arredores paulistanos são sujeitos a uma série de processos que proporcionam grande crescimento da população e expansão urbana sobre os mesmos ${ }^{473}$; e a grande metropolização recente a partir de 1940, quando ocorre a compactação da área edificada, impondo expressivo desenvolvimento dos subúrbios distantes e fim das áreas rurais próximas. $^{474}$

\footnotetext{
471 . Sr. Alípio.

${ }^{472}$. LANGENBUCH, J. R., op. cit., 1971, p.250.

${ }^{473}$. Ibidem, p.131.

${ }^{474}$. Idem.
} 
No município de São Paulo, as duas etapas aparecem como momentos de grandes transformações da paisagem, porém no segundo, quando o crescimento populacional toma grande impulso, é que se define de vez a paisagem urbana como metropolitana. Neste momento é que se estabelece a compactação urbana (os espaços vazios deixados pelos loteamentos anteriores são incorporados ao tecido urbano), a verticalização das áreas centrais e instituição do desenvolvimento periférico apoiado no automóvel e no caminhão. $^{475}$

Neste momento (de concentração urbana, de extensão do tecido urbano e de subordinação completa do agrário ao urbano) ocorre a instalação de um modo de vida urbano. Tal explosão se estabelece como “processo duplo” (industrialização/urbanização) e produz um "movimento duplo" identificado como “explosão/implosão"476. O resultado de tal processo é o fim das antigas relações de vizinhança pré-estabelecidas e o estabelecimento de uma sociedade cada vez mais homogeneizada. Segundo Lefebvre, a condição acima estabelecida é um:

Processo inevitável de dissolução das antigas formas, sem dúvida, mas que produz o sarcasmo, a miséria mental e social, a pobreza da vida quotidiana a partir do momento em que nada tomou o lugar dos símbolos, das apropriações, dos estilos, dos monumentos, dos tempos e ritmos, dos espaços qualificados e diferentes da cidade tradicional. ${ }^{477}$

Os vazios que existiam entre a Penha e a cidade, antigamente ocupados por chácaras de flores, frutas e verduras, desaparecem e tudo se tornou uma única paisagem. A condição de subcentro que a Penha já adquirira na década passada se reforçou e seu equipamento comercial e de serviços tornou-se mais sofisticado, dispensando, em inúmeras vezes, a necessidade de se ir até ao centro de São Paulo. Podemos observar o crescimento da malha urbana penhense no Mapa 7 da página seguinte.

Segundo Martin, tal condição (também verificada na Lapa, Santana e Pinheiros), teve como conseqüência o estímulo dos fluxos entre as áreas mais afastadas do centro e subúrbios com a Penha. ${ }^{478}$

Segundo Lefebvre, trata-se de uma centralidade considerada como:

Movimento dialético que a constrói e a destrói, que a cria ou a estilhaça. Não importa qual ponto possa tornar-se central, esse é o sentido do espaço-tempo urbano. A centralidade não é indiferente ao que ela reúne, ao contrario, pois ela exige um conteúdo. E no entanto, não importa qual seja esse conteúdo . Amontoamento de objetos e de produtos nos entrepostos, montes de frutas nas praças de mercados, multidões, pessoas caminhando, pilhas de objetos variados, justapostos, superpostos, acumulados, eis o que constitui o urbano. [...] $\mathrm{Na}$

\footnotetext{
475. MARTIN, A. R., op. cit., 1984, p.160.

${ }^{476}$. LEFEBVRE, Henri. O Direito à Cidade. São Paulo: editora Moraes, 1991, p.178.

477. Ibidem, p.77-78.

${ }^{478}$. MARTIN, A. R., op. cit., 1984, p.160.
} 
realidade urbana tudo se passa como se tudo o que a compõe pudesse se aproximar, ainda e sempre mais. Assim se concebe o urbano, assim ele é percebido, assim é sonhado, confusamente. ${ }^{479}$

Lefebvre afirma também que:

A cidade atrai para si tudo o que nasce, da natureza e do trabalho, noutros lugares: frutos e objetos, produtos e produtores, obras e criações, atividades e situações. O que ela cria? Nada. Ela centraliza as criações. E, no entanto, ela cria tudo. Nada existe sem troca, sem aproximação, sem proximidade, isto é, sem relações. Ela cria uma situação, a situação urbana, onde as coisas diferentes advêm umas das outras e não existem separadamente, mas segundo as diferenças. O urbano, indiferente a cada diferença que ele contém, é considerado frequentemente como indiferença que se confunde com a da Natureza, com uma crueldade eu lhe seria própria. Contudo, o urbano não é indiferente a todas as diferenças, pois ele precisamente as reúne Nesse sentido, a cidade constrói, destaca, liberta a essência das relações sociais: a existência recíproca e a manifestação das diferenças procedentes dos conflitos, ou levando aos conflitos. ${ }^{480}$

Esses processos serão abordados com mais detalhes quando passarmos a analisar a decadência da vida de bairro na localidade.

479. LEFEBVRE, Henri. A Revolução Urbana. Belo Horizonte: Editora UFMG, 1999, p.110.

${ }^{480}$. Ibidem, p.111. 


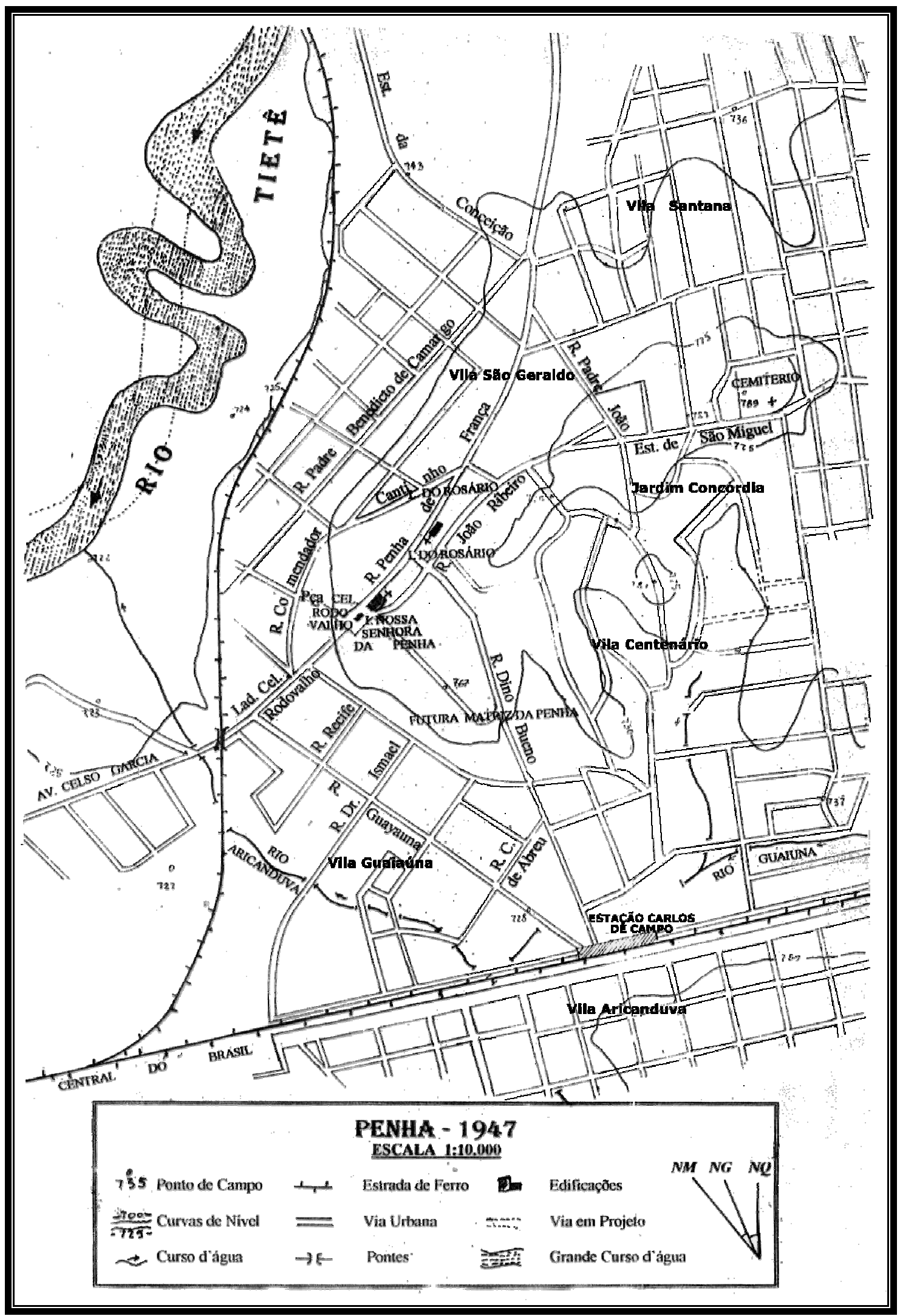

Mapa 7 - Fonte: Planta Geral da cidade de SP, Ed. GeoBrasil, escala 1:20.000, 1947. As curvas de nível foram adaptadas da Carta da Penha de França (indicações diversas), índice de Nomenclatura: SF-23-Y-CV1-2-NE-B, São Paulo-SP, escala 1:10.000, 1981, org. EMPLASA. (Organização e simplificação: Edson Penha de Jesus) 
Deste ponto em diante a designação Bairro da Penha deve ser entendida como unidade administrativa e não mais como uma "pequena” totalidade na totalidade maior que era a cidade.

Na Penha dos anos de 1950 em diante, diferentemente daquelas lojas de velas da década anterior, passam a predominar as lojas de grande envergadura (também presentes no centro da cidade), os serviços bancários, consultórios, escritórios, escolas, cinemas, restaurantes e bares que procuram atender as pessoas que moravam na localidade, as dos arredores e as que usavam o bairro como passagem diária no vai-e-vem dos deslocamentos pendulares. ${ }^{481}$

Vamos, agora, observar as transformações que se processaram no bairro.

Na década de 1950, segundo Sr. Luís:

O Brasil deu um pulo dos anos 40 para os anos 50. Esse pulo aqui na Penha eu não sei como dizer, chegaram os bancos, cinemas, antes, por exemplo, passava um filme na cidade e depois de dois, três meses passava o filme na Penha. Então começaram a aparecer cinemas, cinemas mais modernos, agora quando aparecia um filme na cidade era em conjunto com a Penha, era o Penha Palace [...] outra coisa que foi importante foi o telefone, depois de 50, mais ou menos, começaram a aparecer mais telefones. Antes você podia contar nos dedos quem tinha telefone em casa, era uma deficiência de telefone e em 45/46 começou a se expandir o telefone e assim as pessoas com melhores situações começaram a ter telefone em casa. A Penha começou a se desenvolver mais [...] o comércio foi melhorando, muitas casas de renome começaram a colocar filiais aqui no bairro, a Garbo, por exemplo. [...] Então o que houve de mudança, de notar, é que a Penha passou a ter uma vida mais própria foi a partir dos 50, então começou a ter umas agência da Light, outras de telefonia, bancos e tudo mais e a Penha se entrosou mais na cidade. E eu acredito que isso aconteceu em outros bairros, como Santana, Lapa e tudo mais começou a acontecer mais ou menos isso. O processo de aglutinação. ${ }^{482}$

E segundo Sr. Alípio:

Em 1950 eu tinha 17 anos, já trabalhava, o que mudou naquela época foi um pouco da evolução do bairro, começou a se estender um pouco mais, né, no comércio, nessas coisas. Não tinha só mais lojas de casas de velas e sim outros comércios. Apareceram lojas de calçados, tecidos, o comércio cresce e obviamente cresceu o número de empregos no bairro, mais profissionais liberais começam a aparecer, advogados. No início tinha um dentista na Penha, um médico, o Dr. Barbosa que era o único médico que tinha na Penha e depois começou a evoluir. Nessa época de 50 em diante, começou a aparecer mais médicos e aí o bairro começou realmente a crescer. ${ }^{483}$

O Bairro da Penha tende a ficar cada vez mais parecido com os outros subcentros da cidade. Tal tendência à homogeneização parece inevitável e se fortalece enquanto os traços fundantes do antigo bairro rural, ainda presentes no subúrbio e no bairro se

481. VILLAÇA, Flávio. Espaço Intra-urbano no Brasil. São Paulo: Estúdio Nobel/FAPESP, 1998, p.293. Segundo Villaça, "o subcentro consiste, portanto numa réplica em tamanho menor do centro principal, com o qual concorre em parte sem, entretanto, a ele se igualar. Atende aos mesmos requisitos de otimização de acesso apresentados anteriormente para o centro principal. A diferença é que o subcentro apresenta tais requisitos apenas para uma parte da cidade, e o centro principal cumpre-os para toda a cidade."

${ }^{482}$. Sr. Luís. 
enfraquecem, ou seja, há o enfraquecimento da antiga centralidade que tinha na Igreja sua referência principal.

O fato é que, como fruto da urbanização, dos anos de 1950 em diante, a Penha definitivamente se estabelece como um subcentro e a antiga funcionalidade religiosa, que se manteve forte na localidade até então, tende ao enfraquecimento, mas não ao desaparecimento. Assim, acreditamos que a homogeneização não se completa.

Segundo Seabra,

No urbano sucedem-se, quase indefinidamente, espaços super, hiperfuncionalizados, numa seqüência de homogeneidades geralmente sistêmicas, que formam pesadas estruturas urbanas, as quais, ao se sobreporem às formas pregressas de uso do espaço, como aquelas da cidade com seus bairros, fragmentam-nas. Sendo que fragmentos dispersos dos velhos bairros, permanecendo como residuais, não expressam homogeneidade alguma, não são funcionais e ao contrário, quase sempre funcionam como entraves à mobilidade geral exigida pela urbanização. São espaços residuais que guardam permanências históricas com os quais se pode indagar sobre as genealogias, sobre as coexistências, sobre as continuidades e descontinuidades, sobre as temporalidades e sobre o devir, a partir da premissa 'lei da implicação dos espaços: os espaços se implicam mutuamente' $[. . .]^{484}$

Mescladas às formas da sociedade urbana, tais permanências históricas carregam representações da história da Penha tão relevantes que acabaram nos impulsionando para esta pesquisa.

No entanto, com a mudança de funcionalidade e como fruto dos interesses daqueles que passam a investir seus capitais no bairro uma nova identidade começa a ser construída. Nela, a Igreja perde sua hegemonia e "o bairro passa a ser reinventado ideologicamente". ${ }^{485}$

E nem podia ser diferente, pois as mudanças no uso do solo urbano penhense levam a que ele seja disputado pelos segmentos da sociedade que o compõe. Essa disputa não acontece sem conflitos entre indivíduos e usos e segundo Carlos, "esse pleito será, por sua vez, orientado pelo mercado, mediador fundamental das relações sociais que se estabelecem na sociedade capitalista, produzindo um conjunto limitado de escolhas $e$ condições de vida." 486

Não há lugar nem para a hegemonia da Igreja e nem para a vida de bairro nessa nova configuração sócio-espacial da Penha.

Vamos considerar alguns depoimentos da década de 1950, para melhor entender as transformações ocorridas. Os primeiros estarão relacionados à Igreja penhense.

\footnotetext{
${ }^{483}$. Sr. Alípio.

${ }^{484}$. SEABRA, O. C. L, op. cit., 2003, p.9. Apoiada em LEFEBVRE, Henri. La prudution de l'espace. $4^{\circ}$ ed. Paris: Éditions Anthropos, [1974] 2000, p.110.

${ }^{485}$. RAMOS, A. W. op. cit., 2001, p.142.
} 
Em entrevista com o Sr. Luís,

A partir do final de 40 e tal, o povo já não se deixava envolver pela conversa dos párocos. Nessa época, a voz do padre era a voz de Deus. Nos anos 50 perdeu, não só na Penha, mas eu acredito que no mundo. O penhense deixou de ter identificação, tanto que não tem mais penhense. Não é? Não somos mais penhenses. Eu quis dizer que nos anos 50 não tinha mais aquela identidade [...] A freqüência à Igreja começou a decair extraordinariamente, o motivo eu não sei. Eu sei que ninguém mais ligava pra Igreja, a Igreja não tinha mais aquela força de persuasão. Eu não sei, mas não foi só na Penha que aconteceu ou deixou de acontecer. Isso no mundo. Foi o tempo que a religião tinha influência na vida das pessoas, hoje não tem mais, há muito tempo que deixou de ter. Antigamente, o chefe de família tomava uma decisão e ia conversar com o padre sobre o que ele achava e isso não é do meu tempo. ${ }^{487}$

Segundo Sr. Fábio,

Eu presumo que os próprios padres foram transformando e antigamente saía a procissão e ia até a rua Padre João e dava essa volta. Depois vinha um outro pároco ai [...] e eles mesmo foram alterando, foi modificando, "né"? Por exemplo, não existia missa coletiva. Existia antigamente? Que se lembre, não, "né”? Porém, hoje, "cê” vai, vai à igreja pedir uma missa, pagar uma missa eles fazem ao Domingo. É uma missa coletiva. Num reza uma missa especificamente para uma pessoa. Rezam pra vinte, trinta, assim vão modificando tudo. ${ }^{488}$

E segundo Sr. Júlio,

Uma vez eu estava na farmácia do Marlei, que era uma farmácia tradicional da Penha, chamava Droga Marlei, que era de Antonio Marlei, o padre da paróquia da Penha que tinha bastante amizade com o Marlei e falou assim: desse jeito eu vou ficar pobre porque ninguém vai mais lá me dar a minha contribuição, então minha conta no banco está baixa. Ouvindo isso eu acredito que as pessoas vão se afastando, vão se afastando por motivo que você não está interessado em fazer alguma coisa, você está interessado em dinheiro. ${ }^{489}$

Nestas entrevistas podemos observar que a Igreja na Penha já não apresentava mais a força das décadas passadas. O primeiro depoimento se apresenta como essencial para o entendimento deste enfraquecimento, pois vincula a Igreja à família. Como já havíamos dito e segundo Seabra, “as mensagens da Igreja eram veiculadas para a sociedade através da família, alcançando cada um dos seus membros”490; por meio de irmandades ou congregações que desenvolviam atividades sociais (creche, educação, catecismo, assistência médica etc.) e se faziam portadores desta mensagem.

No entanto, tais famílias ainda tinham o pai como figura central. Uma vez que este, devido às novas formas do viver que o tempo do trabalho impunha, era obrigado a se distanciar da Igreja, a família toda se distanciava.

Tendência que se amplia com o passar das gerações.

Assim, o teor da mensagem se enfraqueceu e deixou de se reproduzir. Tal situação nem poderia ser diferente, segundo Seabra:

${ }^{486}$. CARLOS, Ana Fani Alessandri. A (re)produção do espaço urbano. São Paulo: Edusp, 1994, p.86.

${ }^{487}$. Sr. Luís.

${ }^{488}$. Sr. Fábio.

${ }^{489}$. Entrevista com Sr. Júlio (agosto/2006). 
As grandes orientações do processo social estavam destinadas a realizarem-se no âmbito da família com muita naturalidade, aliás, como se tivessem origem na própria família. Isto porque ao nível do cotidiano as mensagens da Igreja eram imediatamente práticas e, enquanto tais, organizavam as relações com atribuição de funções e papeis a cada um dos seus membros, inserindo-os no conjunto das atividades da paróquia, logo, na vida de bairro. Veja-se que a família abrigava necessariamente muitos dos elementos que o processo de modernização geral da sociedade desencadeava, a começar pelo salário. Logo, se ela era o lugar fundamental para a Igreja, ela era também fundamental à reprodução social já sob o industrialismo. A reprodução do trabalhador nunca pôde prescindir da família. Isto propõe pensar que era a família também um 'lugar natural', a partir do qual o pobre podia emancipar-se dos vínculos da sociedade tradicional até aceder à condição de membro de uma comunidade política. É por isso que seria também esse âmbito, o lugar de realização das orientações mais gerais do processo social, com suas resistências, permanências e mudanças. ${ }^{491}$

Assim, o trabalho assalariado e as opções ideológicas e políticas que a sociedade urbana passou a abrigar "foram transformando a família e atingindo o seu cerne, porque o processo de modernização produz de imediato mudanças na reprodução das familias."492

A primeira entrevista afirma ainda que a Penha perdeu sua identidade e que o penhense deixou de existir. Tal observação nos dá a idéia de que algo se quebrou e que as antigas relações sociais oriundas do vivido no bairro se dissolveram diante das novas estruturas sociais da vida na metrópole. O que o Sr. Carpinetti nos revela é que a vida de bairro havia se esgotado.

Outro fato que nos chamou atenção foi que a própria Igreja local também contribuiu para o enfraquecimento de sua condição enquanto referência do vivido no bairro. Tal fato se apresenta no momento que a mesma decide fazer a nova Matriz do bairro. Segundo Sr. Julio, no começo dos anos de 1960, com a:

Construção da igreja nova [...] eles abandonaram totalmente a Igreja Nossa Senhora da Penha, inclusive a torre da Igreja estava caindo e eles queriam demolir porque ela estava perigosa, porque ela tinha aberto uma fresta de cima embaixo. Foi um temporal forte que deu [...] ela estava totalmente abandonada, porque eles tinham mudado lá pra cima, onde tinha a paróquia, a casa paroquial, tinha não sei o que mais, então a tradicional igreja da Penha ficou abandonada, aí os moradores revoltados com o pessoal do clero, sabem lá de quem, é que se reuniram e reformaram a Igreja da Penha, inclusive não deixou a torre cair. Mas aí eles já tinham levado os sinos, que tinham aqueles carrilhões que tocavam, o relógio não funcionava mais porque eles tiraram e reformaram, rebocaram ela inteirinha por fora, pintaram e passou a ser Museu Histórico da Penha - ou algo assim

Segundo Santarcangelo, a idéia do novo santuário já vinha de longe e em 15 de setembro de 1957, “a Pedra Fundamental do Novo Santuário foi lançada” por "S. Excia

\footnotetext{
${ }^{490}$. SEABRA, O. C. L, op. cit., 2003, p.256.

${ }^{491}$. Idem.

${ }^{492}$. Idem.
} 


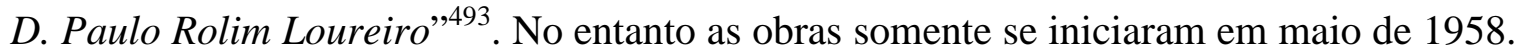

\section{Segundo Santarcargelo}

Sua área ocupa mais de 5.600 metros. O corpo da edificação tem 56 metros de frente por 66 de comprimento. Mede 40 metros de altura. A torre atingirá 65 metros. A cúpula tem 30 metros de diâmetro. Pelas suas arrojadas linhas arquitetônicas e pela decoração ornamental interna será um dos maiores santuários católicos do mundo, pois comportará 7.000 fiéis. Por ocasião das comemorações do III Centenário do bairro da Penha - setembro de 1968 - as solenidades religiosas se efetuarão no Novo Santuário, que deverá estar concluído nessa data. ${ }^{494}$

Assim, a própria igreja penhense, enquanto símbolo da religiosidade ou enquanto espaço de representação da sociedade penhense, contribui para o processo de desestruturação do antigo paroquialismo que predominava no vivido local. A nosso ver, ao se estabelecer a necessidade de uma nova Matriz, a antiga igreja de Nossa Senhora da Penha de França que era a referência da vida de bairro, também perdeu seu caráter simbólico e teve sua imagem associada a outro uso que não o religioso. Enquanto referência, a igreja virou uma espécie de museu, virou uma representação do espaço e deixou de ser monumento. ${ }^{495}$

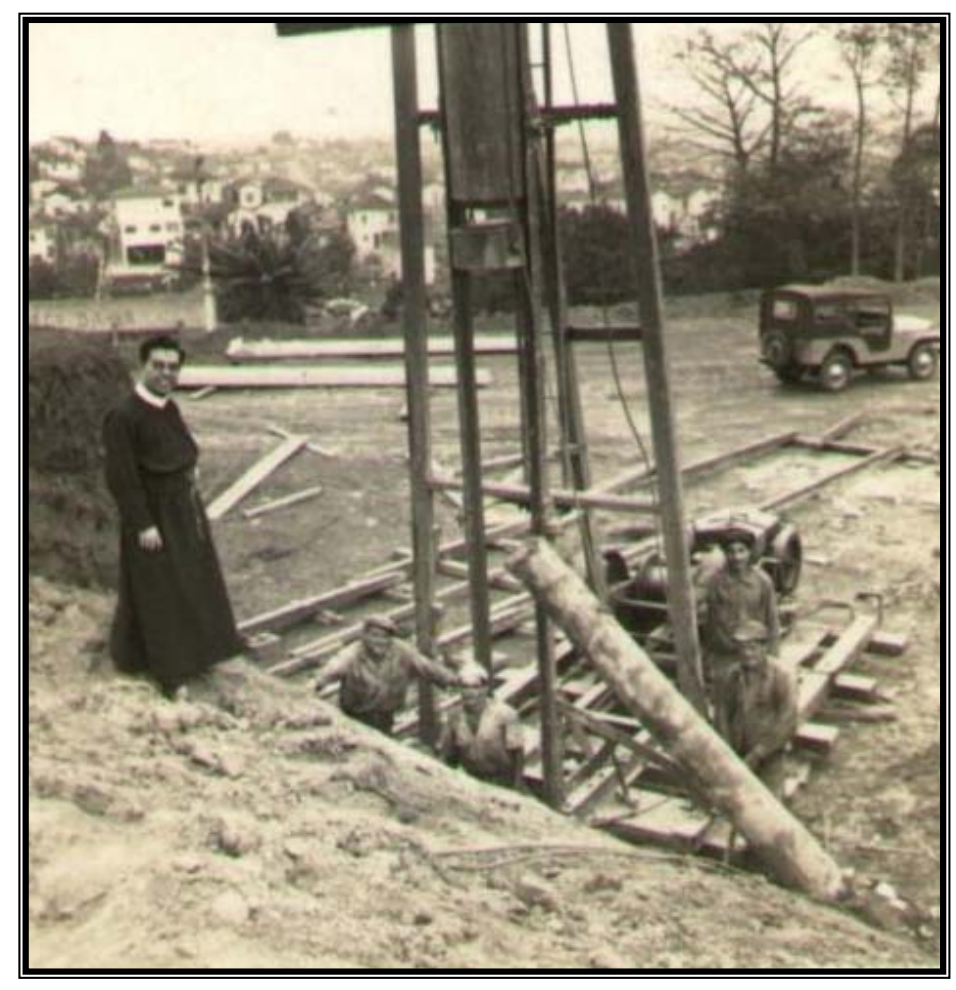

Início das obras da Nova Matriz da Penha em 1957 - Assistida pelo padre José Augusto da Costa. (Memorial da Penha de França, acervo digitalizado)

A igreja teve seu

${ }^{493}$. SANTARCANGELO, M. C. V., op. cit., 1968, p.44.

${ }^{494}$. Ibidem, p.44-45.

${ }^{495}$. OSEKI, Jorge Hajime, O único e o homogêneo na produção do espaço. In: MARTINS, José de Souza (org.). Henri Lefebvre e o retorno à dialética. São Paulo: Editora Hucitec, 1996, p.110-118. 
simbolismo usurpado e tornou-se produto das novas concepções do urbano e o monumento foi suplantado pelo edifício. Segundo Oseki,

uma grande transformação ocorre quando o edifício suplanta o monumento. No edifício impera a racionalidade do repetitivo e do identitário, o que importará agora é ser visto e não ser vivido. Com o edifício a vida cotidiana idealizada pelo consumo dirigido se instaura, assim como a hierarquia dos espaços importantes e corretos sobre o espaço comum. O monumento vai reaparecer em caso de opressão e repressão urbanísticas explicitas. ${ }^{496}$

Já a nova Matriz, não conseguiu reivindicar para si o conteúdo poético da antiga igreja de Nossa Senhora da Penha e não virou referência. É apenas um edifício. Nesta condição "segrega os elementos da pratica social e tem uma função própria, uma estrutura própria e uma forma própria. A textura urbana se desfaz e a coesão se dá pela violência." ${ }^{497}$ Haveria a possibilidade da nova Matriz tornar-se monumento? A resposta seria não. Segundo Oseki , "uma nova sociedade (no caso a urbana) poderia inventar, criar, produzir formas novas” ${ }^{498}$, no entanto, as relações de produção e propriedade impedem essas possibilidades, pois o espaço já foi fragmentado.

Outro elemento que, na fala de alguns entrevistados, teria contribuído para o fim da vida de bairro na Penha foi a chegada de judeus e nordestinos.

Podemos observar na entrevistas, que para os antigos moradores, a chegada de judeus e nordestinos na década de 1950 também se apresenta como fator de desagregação das antigas relações sociais do bairro. Diferentemente dos operários e comerciantes italianos, portugueses e sírios-libaneses que chegaram ao bairro durantes as primeiras décadas do século vinte, esses novos moradores não se “tornaram penhenses”.

E nem poderia ser diferente, os anos de 1950 apresentavam realidade muito diferente das décadas anteriores. O desenvolvimento do urbano e da cotidianidade, estabelecidos pela industrialização, e as novas fronteiras físicas e ideológicas impostas pela metrópole não permitiam que relações sociais mais profundas se estabelecessem no bairro. Aliás, se até as relações entre os antigos moradores já estavam comprometidas, como esperar que esses novos moradores viessem estabelecer uma relação de vizinhança no bairro?

Observemos as entrevistas e depois vamos às devidas análises. Segundo Sr. Alípio,

No início a gente tinha mais influência do italiano, do português que vieram, depois dos 50 já começou a vir gente fora desse nível de pessoal, foi pessoal

\footnotetext{
${ }^{496}$. Ibidem, p.118.

497 . Idem.

498 . Idem.
} 
daqui mesmo, de outros Estados pra cá e começou a fazer modificações. Geralmente aparecia gente do Nordeste. ${ }^{499}$

Segundo o Sr. Luís,

Daí começou a aparecer nordestinos, já em toda cidade, principalmente aqui na Zona Leste, eles vinham muito para os arredores da Penha, inclusive São Miguel e de lá vieram pra cá e implantar um comércio diferente, que nós não estávamos acostumados, o comércio do meio de rua, que hoje são chamados de camelôs e começaram a aparecer. No princípio a gente achava até cômodo, interessante eles correndo dos fiscais. Aos poucos foram tomando conta e hoje está como está. Começaram a aparecer aí, aliás eu acho que os nordestinos começaram a aparecer bem antes, não foi só em 1950 não. A época eu não sei direito, mas começaram a aparecer aqui, aparecer nordestinos, apareceu desde a Revolução de 30 e São Paulo passou a ser invadida, tomada por eles, houve a Revolução de 30 - foi a revolução de Getúlio Vargas que derrubou Washington Luis e não aceitou aquela eleição fajuta, não é isso? E daí ele começou a mandar pra cá levas de nordestinos, nas repartições, nos governos e assim São Paulo foi tomando conhecimento dos outros brasileiros que vem do Ceará, da Paraíba, da Bahia e nós fomos perdendo até um pouco da nossa identidade, até no falar o paulista foi perdendo a identidade. [...] Olha, eu não gosto muito de falar, mas a questão de educação, de costumes, completamente diferentes dos nossos, que nem eu falei do comércio, do modo de se vestir, começou a perder aquela... porque a Penha, apesar da época, tinha a sua elite, vamos dizer, classe média, põe seu terno de domingo e vai na rua da Penha passear. Daí já começou a avacalhar. Mas isso foi uma coisa que foi acontecendo não só na Penha, mas na cidade também, foi se deteriorando. As lojas deixavam à noite vitrine. Eu me lembro que chegava 22:30h e $23 \mathrm{~h}$ e chegavam aqueles empregados para arriar as portas das vitrines das lojas. Até então ficava tudo exposto, vidro comum, assim. Depois, com o tempo, já não era mais possível. A loja não tem mais vitrine. [...] Antigamente não, gostava muito de pôr as cadeiras na calçada, ficar conversando e isso tudo foi acabando e a gente sentia foi isso, mas isso não foi só na Penha, foi na cidade toda. Houve uma invasão de bárbaros. Virou uma mistura tremenda. Não é que eu não goste, por exemplo como eu falei, tem nordestino na minha família, mas costumes completamente diferentes. E o pior, os que vieram pra cá não eram da cidade de Salvador, de Recife, foi bem do sertão da Bahia, de Pernambuco, pessoas completamente despreparadas para viver na cidade, esse que foi o problema. Eu não gosto de dizer isso, que os nordestinos acabaram com a Penha. [...] Não foram eles só, os nordestinos, também começou a aparecer aqui muitos judeus, com a guerra, depois da guerra vieram fugidos da Rússia, da Alemanha, apareciam muitos judeus que trabalhavam em lojas de móveis, em casa de móveis. Os árabes eram armarinhos, na Rua da Penha, em 40 começaram a aparecer os judeus em casas de móveis. Judeus e nordestinos foram modificando a fisionomia do bairro, no modo de vida. Antigamente era bem diferente. [...] Judeus vieram com casas de móveis, eles não se encaixaram na Penha, igual aos árabes. Por isso que é um povo marcado, porque isso aí acontece com o povo judeu porque eles foram praticamente expulsos da Palestina, então quando eles saíram da Palestina, para não perder identidade, eles se comprometiam de continuar casando entre eles, então foram pra Polônia, pra Alemanha, pra França, pra Espanha, mas se mantiveram unidos na religião e casando entre si, não se misturavam [...] Antigamente para sair na Rua da Penha você não ia de qualquer jeito, de shorts, você ia de camisa, um pouco mais arrumadinho, você ia mais assim. E depois foi muito relaxado. Eu não me lembro se incomodava, porque até então eu era moço, não dava atenção muito a isso. Eu ia aceitando as coisas, nunca chegou a me incomodar $[. . .]^{500}$

\section{E de acordo com o Sr. Fábio,}

Mudou bastante, começou depois da guerra. Começou a vir esses paus-de-arara de lá... Os nordestinos, né? [...] eles começaram a ‘vim’ após, após guerra. Depois

499 . Sr. Alípio.

500 . Sr. Luis. 
de 1945, começou a 'vim', "né”? A gente não sentia muito a presença deles [...] Aí começou a se fundar. Foi inaugurada aquela Nitro-Química de São Miguel e lá ocupava muito operário, né? Morria muita gente lá, então o povo [?] que ia lá trabalhar na indústria. [...] Aí, daquela década em diante aqui se transformou, lá, nisso aí. Outra, aquilo lá foi formado por mais nordestinos.[...] E aqui na Penha tinha o reflexo de lá, "né"? Eles vinham, aqui era o centro, São Miguel era o interior. Então para eles, aqui era o centro. Vinham de lá para cá. Aí começou a se mobilizarem para construir núcleos nas adjacências. Aí, os terrenos da Dona Maria Carlota foram, foram vendidos quase todos [...] Eu não digo pra nordestinos. Mas, ah! Eu digo, ah! O, a povoação, "né”? Mas aí, os nordestinos começaram a vir e residir nas imediações, não é? Não digo aqui, junto da Penha. Mas aqui pela, pelo Guaiaúna, Alto do Guaiaúna, São Miguel, Vila Esperança. Foram tomando conta, hoje ficou esse, essa imundice que nós temos aí.Olha, se eles construíram alguma coisa, eles destruíram muito aqui, viu? Porque aqui na Penha e o Brás eram lugares que você admirava, "né”? Hoje, isso aqui é uma nojeira você toma um, um ônibus aqui, passa naquela Rangel Pestana e vê aquela imundice ali. No centro da cidade também, "né"?

Como podemos observar, a experiência resultante da chegada destes novos moradores, principalmente nordestinos apresentou-se traumática e nada interessante para os antigos penhenses. Na visão destes, que se autodenominam herdeiros da cultura do bairro, dividir o espaço com os novos moradores se apresentou como uma experiência que podemos classificar de perda e uma espécie de disputa pelo bairro se estabelece. Tal disputa não aconteceu somente no campo da cultura e do simbólico, se realizou também na luta pelo mercado na porção central do bairro. Assim, a luta pelo território se ampliou.

Diferente dos imigrantes operários que começaram a chegar ao bairro no começo do século vinte e que vieram para ocupar os loteamentos e não ameaçavam o comércio local, judeus e nordestinos, ao se inserirem neste setor econômico tornaram-se uma ameaça à antiga ordem local. Acreditamos que tal condição acirrou a luta pelo espaço e impediu uma aproximação identitária entre os dois grupos.

Mais uma vez podemos observervar o enfraquecimento das relações sociais que cimentavam a vida de bairro.

Sobre essa questão, Seabra esclarece que:

A urbanização contemporânea entendida como processo de transformação qualitativa no modo de viver segue continuamente e coloca no horizonte a possibilidade de uma sociedade urbana. Nessa sociedade estariam profundamente alterados os modos de vida em relação a situações precedentes, pois, o sentido da urbanização tem conduzido ao domínio da impessoalidade implicando na alteração de todos os vínculos, na sujeição do tempo. Do espaço, do corpo, aos ritmos e sentidos prescritos pela lógica do mercado. Tudo se compra, tudo se vende. $^{502}$

${ }^{501}$. Sr. Fábio.

502. SEABRA, Odete Carvalho de Lima. Memória, Cidade e Paisagem. São Paulo, s/d, 5p. (mimeo) apud. RAMOS, A. W. op.cit., 2001, p.161. 
Segundo Ramos, a partir desta idéias de mudanças nos modos de vida, é que podemos observar como a forma de viver da cidade se alterou desde o começo do século vinte até os dias atuais, quando São Paulo se transforma em metrópole mundial. ${ }^{503}$

Ainda pensando no espaço sob a lógica do mercado, segundo Simmel, a mente moderna tornou-se cada vez mais calculista e isso influenciou diretamente a vida prática transformando o mundo em problema aritmético. Para este autor,

Somente a economia do dinheiro chegou a encher os dias de tantas pessoas com pesar, calcular, com determinações numéricas, com uma redução de valores qualitativos a quantitativos. Através da natureza calculativa do dinheiro, uma nova precisão, uma certeza na definição de identidades e diferenças, uma ausência da ambigüidade nos acordos e combinações surgiram nas relações de elementos vitais - tal como externamente esta precisão foi efetuada pela difusão universal dos relógios de bolso. Entretanto, as condições da vida metropolitana são simultaneamente causa e efeito dessa característica. Os relacionamentos e afazeres metropolitano típico são habitualmente tão variados e complexos que, sem a mais estrita pontualidade nos compromissos e serviços, toda a estrutura se romperia e cairia num caos inexplicável [...] Assim a técnica da vida metropolitana é inimaginável sem mais pontualidade e integração de todas as atividades e relações mútuas em calendário estável e impessoal [...] Pontualidade, calculabilidade, exatidão, são introduzidas à força na vida pela complexidade e extensão da existência metropolitana e não estão apenas muito intimamente ligadas à sua economia do dinheiro e caráter intelectualístico. Tais traços também devem colorir o conteúdo da vida e favorecer a exclusão daqueles traços e impulsos irracionais, instintivos, soberanos que visam determinar o modo de vida de dentro, ao invés de receber a forma de vida geral e precisamente esquematizada de fora. ${ }^{504}$

Desta forma, todos os reflexos do dinheiro passam a ser estímulos para a o conteúdo e a forma da vida metropolitana.

Diante do que foi apresentado nos parágrafos anteriores, podemos observar que no viver metropolitano as relações comunitárias, de indivíduos, de grupos familiares e de vizinhança, se dissolvem e a impessoalidade se amplia. No entanto, essas relações não podem ser consideradas como fruto de uma evolução linear. ${ }^{505}$

Segundo Ramos,

[...] na grande metrópole há elementos comunitários, assim como há, na atualidade, elementos do modo de vida metropolitano tanto nas pequenas cidades, quanto nas comunidades agro-pastoris, isso porque há uma coexistência das diversas formas de sociabilidade de maneira sobreposta; o que Martins chama de diversas temporalidades que são datadas, porém, contemporâneas $[. . .]^{506}$

${ }^{503}$. RAMOS, A. W. op. cit., 2001, p.161.

504. SIMMEL, Georg, A metrópole e a vida mental. In: VELHO, Otávio Guilherme (org. e trad.). O Fenômeno Urbano. $2^{\mathrm{a}}$ edição. Rio de Janeiro: Zahar Editores, 1973, p.14-15

505 . RAMOS, A. W. op.cit., 2001, p.162.

506. Idem. Ramos cita MARTINS, José de Souza._Suburbio - Vida Cotidiana e História no Subúrbio da Cidade de São Paulo: São Caetano, do fim do império ao Fim da Republica Velha. São Paulo/São Caetano, Hucitec/Prefeitura de São Caetano do Sul, 1992. 
Assim, como princípio explicativo de grande importância, o entendimento do Bairro da Penha passa pela necessidade de compreensão da existência de sobreposição de temporalidades.

Nas entrevistas observamos que tais temporalidades se encontram cristalizadas pela memória.

Assim, para melhor entendimento da vida de bairro na Penha é que recorremos à memória dos antigos moradores. Para ilustrar, vejamos, a partir dos depoimentos a seguir, como era e em qual intensidade se apresentava a vida de bairro penhense antes da metropolização.

Segundo a Sr ${ }^{\mathrm{a}}$. Elizabete:

Saudade... dos meus bailinhos, de não ter preocupação com nada, aqueles bailinhos que a gente freqüentava sem maldade [...], do cine Júpiter, aonde eu fui muito lá [...] do domingo, a gente pegava a bicicleta, que também era uma delícia, ia até a Hortolândia que era ali perto da estação Carlos de Campos e era um lugar fechado, passava um córrego que era uma água bem fresquinha. Bem úmido aquele lugar e a molecada ia toda pra lá. [...] Ela [a família] ia para o Clube Esportivo da Penha. A família inteira de fim de semana já freqüentava o clube, quando meu pai estava de folga também, tinha outro sócio também. Além do clube, o que mais tinha na Penha para fazer com a família? Tinha quermesse, em junho, tinha leilão, a gente ia pra lá pai e mãe. E fora dessa época? Igreja: ia na missa e pronto. Depois da missa íamos direto pra casa, aí à noite, na rua da Penha os rapazes ficavam na calçada e as moças passavam. [...] Eu era nova ainda, tinha a [padaria] Radia Azul, que era na Betari tinha um comerciante que ele passava uns filmes, que era continuação, então todo sábado a gente ficava ali na Radia Azul para assistir os filmes. Era um cineminha [...] nesse Radia Azul que a gente ficava todo em pé, olhando, ficava aquela molecada toda. Era a esquina da Betari com a Almeida Nogueira. Bons tempos, que saudade! ${ }^{507}$

Segundo o Sr. Luís,

Você sabe que a Penha era um bairro quase assim uma cidadezinha do interior anos atrás, não era como é hoje, ela está distante do centro da cidade uns 10 ou $12 \mathrm{~km}$, não sei muito bem, mas a gente aqui falava ao invés de dizer 'eu vou na Praça da República' ou 'eu vou na rua 15', dizia eu vou na cidade, quer dizer então que era considerado aqui como uma cidadezinha do interior [...] tinha muito penhense que ficava meses sem ir para a cidade. Quase tudo que precisava encontrava aqui [...] aqui todo mundo era conhecido de todo mundo, você saía na rua e dizia 'oi, como vai' ou 'bom dia, boa tarde'. Era um tempo que tinha muitas lojas de fazenda, de armarinhos na rua da Penha, de famílias sírias, descendentes. E era usual colocar as cadeiras na calçada à noite, de tardezinha, fechavam a loja e ficavam na conversa ali. Tinha também de interessante na Penha era o 'footing', o passeio, o famoso. Tinha no Brás, tinha na Penha. [...] Mas a partir de 1940 o negócio foi se modificando e foram chegando pra cá imigrantes, a Penha foi se desenvolvendo e acabou aquela Penha poética daquele tempo, e foi passando a ninguém se conhecer mais direito. ${ }^{508}$

Nas palavras do Sr. Pacha,

Eu me lembro de uma imagem no centro da Penha. Enfrente ao grupo escolar da Penha, ali no [?] da Penha. Tinha, me recordo 16 coqueiros. Era muito bonito, era uma paisagem. Ficava em frente ao grupo da Penha. Primeiramente ele recebeu o nome de grupo escolar da Penha e depois Santos Dumont, era o mesmo grupo.

507 . Entrevista com Sra . Elizabete (agosto/2006).

508 . Sr. Luís. 
[...] O comércio ainda era muito singelo, viu? Muito pequeno, onde predominava a casa de vela, onde eram definidas as velas para pagar promessas da Virgem. O dia mais querido era o sábado. [...] Onde era predominante morador sempre com sorrisos. Predominava muito, porque era hábito. Um hábito muito alegre dos moradores [...] Geralmente era comum quase em todas as casas celebrações de aniversários, casamentos e se fazia festa quase que o convívio dos moradores eram todos... todos, quase um pacto. ${ }^{509}$

Nos três depoimentos podemos observar como as relações de vizinhança eram intensas e como a vida se processava a partir de forte sociabilidade. Sociabilidade que se estabelecia na praça, na rua, na igreja, no bar, no armazém, no cinema, no clube e em outras áreas onde pessoas se encontravam e trocavam olhares e palavras de cumplicidade.

A relação espacialidade/sociabilidade, enquanto identidade acentuava a idéia de fazer parte de algo em que todos participavam.

Colocar a cadeira e contemplar o mundo se tornou impossível para o modo de vida metropolitano. Segundo Ramos, ao analisar os resultados do processo de metropolização, o modo de vida metropolitano acabou chamando as pessoas cada vez mais para dentro de suas casas ("para o espaço privado, para o espaço individual”). ${ }^{510}$ Os moradores, “recolhem as cadeiras da calçada, fecham as janelas e não compram mais no armazém da esquina (local em que encontram os vizinhos e no qual mantinham, com o dono, uma relação de afinidade, confiança e até, de afeto)." "511 $\mathrm{O}$ autor avança até os dias atuais e complementa: "Hoje, diferentemente, as pessoas entram no carro e vão às compras num grande supermercado de uma rede transnacional ou num 'shopping center', locais privilegiados de consumo, onde não se conversa com o dono, encontrar um vizinho seria mera coincidência e tudo é organizado para pontencializar o consumo."

O fim da vida de bairro aparece nas entrevistas como um processo espontâneo e inevitável.

Elementos para apreender a dissolução da vida de bairro aparecem na fala de alguns dos entrevistados:

Quando perdeu isso, perdeu aquele lado pitoresco da Penha, aquele bairro tradicional, de comércio, da santa padroeira, da festa do santo, começou a deixar de existir isso, então a Penha começou a fazer parte do todo, da cidade. Não tinha mais aquele negócio de ir na Penha pagar uma promessa ou ir na festa da Penha, acabou nisso daí que existia e deixou de existir. A Penha... eu tinha um parente que morava na Liberdade - aqui era a parte pobre e ele então quando vinha para a Penha e eu era garoto, ele vinha como se viesse para uma cidadezinha do interior, visitar os parentes pobres. Você sabe que a maioria das casas tinha galinheiro, todo mundo tinha galinha, então quando você fosse comprar um frango, as mulheres traziam os frangos pendurados pelas pernas e destroncavam o pescoço. Então a Penha foi isso, foi se modificando nesse sentido, foi fazendo parte da

\footnotetext{
${ }^{509}$. Sr. Pacha.

${ }^{510}$. RAMOS, A. W. op.cit., 2001, p.175.

511 . Idem.

${ }^{512}$. Idem.
} 
cidade. Aliás, São Paulo foi se expandindo tanto... Mas isso foi uma coisa que foi acontecendo não só na Penha, mas na cidade também, foi se deteriorando. [...] Antes a gente perguntava onde mora? Eu moro na Penha, mas depois de um tempo houve até um desprestígio você dizer que mora na Penha, começa assim porque era tão distante: o bonde levava $45 \mathrm{~min}$, o ônibus 30min pra cidade e quando se falava eu moro na Penha... Eu me lembro de quando eu fui trabalhar na Rhodia, em Santo André e tudo mais, quando eu dei o endereço Penha, eles titubearam: 'na Penha você quer trabalhar em Santo André?'. Compreende. Eu falei 'não tem problema, eu levanto cedo e chego aqui na hora'. Mas eles sempre ficavam com a pulga atrás da orelha. Não era só nestes casos que era ruim falar que morava na Penha, as meninas também não gostavam de falar que moravam na Penha. Antes não. Era quase que uma cidadezinha do interior, mas depois que sentiu o bairro então falava que a Penha ficou pra trás mesmo dos outros bairros, como está até hoje [...] todos aqueles que sobressaíram aqui na Penha, por ganhar dinheiro ou por curso superior e tudo mais, foram deixando o bairro, não por vergonha da Penha, mas porque a Penha é fora do miolo, compreende. Do movimento da cidade e tudo mais. [...] As mudanças o pessoal foi aceitando paulatinamente, foi modificando o sistema, e isso a gente foi aceitando, se Para o Sr. Alípio, adaptando e sem perceber está aí, mas nunca houve uma reação dos penhenses. ${ }^{513}$

Porque tem gente até que a gente lembra, principalmente moças, nessa época de 50 e foi até 60 ou mais, que tinha até vergonha de dizer que era da Penha, isso em 50. Vergonha de dizer que era da Penha, porque a Penha era considerada um nível pouco, um bairro desprezível, desprezado, como caipira, então nessa época de 50 e até 60 ainda tinha essa influência de dizer que era da Penha. Eu, por exemplo, moro, vivo e tenho orgulho de dizer que sou da Penha. Mas até hoje, a grande maioria do pessoal que vivia na Penha, comerciantes, industriais, que estabeleceram isso aqui, quando ganha 10 mil réis vão embora da Penha, inclusive políticos, como esse tal de Bicudo. E isso em 50/60, até pouco tempo ainda tinha muito isso. Naquela época o povo ia para Morumbi, Pinheiros, outros bairros de maiores parques como Sumaré. Em torno de 50 já não tinha mais sensação de cidadão penhense, principalmente entre os homens. Falava assim: ih, mora na Penha. [...] Fazer parte da cidade foi algo bom para o penhense, ruim não. Você pertence a São Paulo, formou-se um bairro numeroso, populoso, respeitado. [...] Eu acho que é um período de evolução, deixou de ser uma coisa bairrista para fazer parte da metrópole. Uma evolução que tinha que acontecer um dia e aconteceu nessa época. ${ }^{514}$

O fato é que o processo de metropolização leva à homogeneização. Os envolvidos no processo sequer se dão conta do que os atropelou.

Segundo Simmel, com a metropolização confere ao individuo uma liberdade pessoal nada parecida com o que ele vivenciou anteriormente, e à medida que um grupo cresce numericamente, espacialmente e em significado e conteúdo de vida, "na mesma medida, a unidade direta , interna, do grupo se afrouxa e a rigidez da demarcação original contra os outros é amaciada através das relações e conexões mútuas. Ao mesmo tempo, o indivíduo ganha liberdade de movimento muito além da primeira delimitação ciumenta."515 Simmel, afirma ainda que a metrópole se caracteriza pela independência

\footnotetext{
513 . Sr. Luis.

514 . Sr. Alípio.

${ }^{515}$. SIMMEL, G., op. cit., 1973, p.20
} 
essencial “até das mais eminentes personalidades individuais. Isso é a contrapartida do preço da independência que desfruta na metrópole. "516

Sobre esse processo de individualização e de "libertação”, Simmel complementa que “a pessoa precisa enfrentar a dificuldade de afirmar sua própria personalidade no campo abrangido pelas dimensões da vida metropolitana.” Assim, o homem é tentado a adotar "as extravagâncias especificamente metropolitanas do maneirismo, capricho e preciosismo."517 Entre eles estão a busca por uma nova identidade que não está mais associada ao bairro e sim a metrópole.

Segundo Ramos,

A existência do bairro ocorre se os grupos sociais de forma objetiva e subjetiva têm o sentimento de pertencimento a determinado espaço. Em outras palavras, os grupos sociais devem existir e exteriorizar de alguma forma a questão do pertencer a tal espaço e é este sentimento de pertencimento coletivo que dá sentido e coesão ao bairro. [...] Deve haver, portanto, o compartilhamento de determinadas referências espaciais comuns para existir o bairro. Quando a urbanização começa a destruir tais referenciais e em não havendo uma forma de resistência coletiva por parte dos moradores [...] o bairro deixa de existir. ${ }^{518}$

O processo de metropolização não faz concessões.

Para finalizar, década de 1950 apenas confirmou o que já era anunciado na década de 1940, que o modo de vida metropolitano se estabeleceria e que a fragmentação, enquanto conseqüência da implosão do bairro dizimaria qualquer possibilidade da sobrevivência da vida de bairro na localidade.

\footnotetext{
516. Ibidem, p 21

517 . Ibidem, p 22

${ }^{518}$. RAMOS, A. W. op.cit., 2001, p.178
} 
Considerações finais 
O estudo sobre o Bairro da Penha, de sesmaria à década de 1950, procurou buscar elementos que permitissem o entendimento de como se efetuou a passagem do rural para o urbano na localidade.

O exame desse processo levou ao estudo dos modos de vida que se constituíram na localidade. Tal estudo distinguiu três momentos: a constituição da Penha enquanto bairro rural; a constituição da Penha enquanto subúrbio e; a constituição Penha enquanto bairro paulistano.

Para o entendimento da constituição da localidade enquanto bairro rural, inicialmente procurou-se identificar como se deu o processo de ocupação e uso do solo na região da Penha. Porém, por se tratar de um aglomerado de origem religiosa, a Igreja Católica passou a se apresentar como fator fundamental para a compreensão da espacialidade local.

A religiosidade e todos os seus agentes e mitos davam a tônica da organização sócio-espacial local. Nesse período o aglomerado se apresentava isolado da cidade de São Paulo e pouco necessitava das decisões da cidade para a organização local.

Tudo que era de interesse da localidade era decidido “entre as paredes da capela”. Nesse período, o Estado atrelava-se à influência do catolicismo para garantir o respeito das ordenanças. Essa posição do poder central fortalecia ainda mais as posturas hegemônicas da Igreja e de seus ilustres membros, os homens bons.

Assim, a religiosidade, dotada de intensa prática política, tornava a Igreja Católica um poder incontestável e de grande influência sobre a população local. No entanto, essa hegemonia, que durou por mais de três séculos, foi perdendo força com o processo de modernização da sociedade brasileira. Como elementos dessa modernização, destacamos aqui: a Lei de Terras de 1850, a instauração da República, a industrialização e a urbanização.

Sobre a primeira, que permitiu a posse definitiva e privada da terra, temos dois fatos importantes: a transformação das antigas concessões de datas do patrimônio religioso em terrenos particulares; e a transformação dos adros e entornos da capela em logradouros públicos.

Com a instauração da República em 1889, temos o rompimento político entre a Igreja Católica e o Estado: nesse momento da história, a Igreja perde grande parte de sua influência sobre a política nacional e vê seu poder político, tão bem trabalhado na definição do uso dos espaços circundantes às capelas, reduzido às exigências e interesses da burocracia estatal. 
A industrialização e a urbanização, com todas as mudanças econômicas, sociais e políticas por elas proporcionadas, acarretam transformação do modo de vida não só porque estabelece o cotidiano da grande cidade, como atrai milhares de imigrantes e migrantes que vão se espalhar pela cidade e romper com os antigos costumes dos bucólicos aglomerados que orbitavam a cidade de São Paulo.

Enquanto bairro rural, observamos dois momentos que devem ser destacados: a Penha enquanto arraial e a Penha enquanto freguesia rural.

Como arraial: pudemos observar que as relações com a cidade de São Paulo eram limitadas pela distância e pela ausência de vias que apresentassem qualidade para o deslocamento de pessoas e mercadorias. Durante esse período, a única via de ligação era o caminho para o Rio de Janeiro, também conhecido por caminho da Penha, que atravessava áreas alagadiças do vale do Tietê. Nesse período o aglomerado se apresentava quase que auto-suficiente, trazendo da cidade apenas o que realmente não era possível produzir na localidade. Se, do ponto de vista econômico, a comunicação entre o aglomerado e a cidade era uma nulidade, do ponto de vista religioso apresentava grande destaque.

Como freguesia rural: a ligação com a cidade de São Paulo se intensifica e a região passa a se apresentar como zona rural de abastecimento. Com a melhoria da Estrada da Penha (antigo caminho da Penha), por meio de pontes e cuidados maiores, o trânsito das carruagens e mulas torna-se mais fácil e menos demorado. Do final desse período é ainda a chegada das linhas de bondes de tração animal e depois da ferrovia. Ao mesmo tempo em que o laço econômico entre a localidade e cidade aumentou e laços religiosos também. Além das procissões, o fluxo de romeiros e visitantes para a localidade aumentou muito e isso se tornou fator definitivo para o desenvolvimento comercial local e a estruturação da Penha como centro regional.

Até esse momento temos a definição da localidade penhense com base em uma sociabilidade estabelecida em um longo tempo e a partir de um modo de vida rural. No entanto, com a aproximação com a cidade, por meio da ferrovia teremos um espaço em transição ou como um limite entre o rural e o urbano. Daí termos considerado a Penha um subúrbio próximo. Apesar da aproximação com a cidade, a Penha caracterizava-se ainda como espaço rural do entorno paulistano, mas já no horizonte da urbanização.

Com a chegada dos trilhos da Central do Brasil e do seu ramal Poá, junto com a crescente industrialização da cidade, as antigas áreas de produção de insumos agrícolas foram cedendo espaço para acolher os loteamentos para a classe operária; a Igreja 
Católica ainda se apresenta como forte referência para a população, no entanto começa a sofrer com as novas ideologias que aparecem na Penha; o modo de vida rural ainda se mantém, no entanto a sociedade urbana avança e começa a enfraquecer e ameaçar as antigas sociabilidades locais.

Como pudemos observar, ainda no início do século vinte, a comunidade se reunia antes, durante e após as práticas religiosas e festividades e lá desenvolvia as trocas de experiência, a diversão, a solidariedade e a organização da vida do aglomerado. No centro estava a Igreja, que centralizava essa comunhão social por meio de confrarias leigas ou religiosas, cada uma com seus objetivos no trato das questões sociais que só interessavam à coletividade local. Não podemos esquecer que essa população era, em grande parte, formada por agricultores que nas cercanias do aglomerado viviam.

Nas décadas de 1940-1950, como resultado da urbanização/indus-trialização que já anunciam a metrópole observamos que a cidade e a vida ganhou novos conteúdos propriamente urbanos. Este seria o período de consolidação da Penha enquanto bairro paulistano e, também, o período em que se inicia a dissolução da sociabilidade definidora da vida de bairro.

O crescimento urbano e a penetração do capitalismo trouxeram novos moldes às relações sociais penhenses. O que vemos é a inserção dos novos e velhos moradores do bairro ao mundo do trabalho urbano e, como resultado, pudemos constatar a mudança dos ritmos de vida e o estabelecimento definitivo do modo de vida urbano na Penha. Tal processo colocou em cheque as relações de vizinhança e as representações religiosas, antigos alicerces da vida de bairro na Penha.

As novas relações sociais ritmadas pela difusão do dinheiro e do assalariamento transformaram o tempo de uso comum (do vivido, das relações de vizinhança, paroquianas) em tempo social (do trabalho, da indústria). Segundo Seabra,

[...] à medida que o tempo próprio era consumido em favor do tempo social abstrato, o espaço também o era. O tempo social, construído no movimento do trabalho social, produz o espaço social. Isto permite concluir que uma inserção excludente no tempo social se traduz pela ausência de espaço, sem eliminar a necessidade do território para uso. ${ }^{519}$

Assim, as novas relações que a industrialização impunha à cidade e seus bairros comprometeram o papel centralizador (da sociabilidade) da Igreja estabeleceram um novo modo de viver no Bairro da Penha. O espaço da sociabilidade, do lúdico, da construção coletiva, da reza, das trocas de experiência, do sagrado, da solidariedade, enfim da

519. SEABRA, O. C. L, op. cit., 2003, p.213. 
essência clerical e religiosa, perderam sua profundidade. Ações impostas pelo Estado e pelo mercado passaram a orientar esse processo. ${ }^{520}$

Segundo Seabra, aquele tempo próprio do bairro, comum e cotidiano, de origem coletiva, carregado de positividade e de enorme criatividade foi possível "porque havia espaço possível, foi uma obra própria e singular, expressa nos conteúdos da vida de bairro sempre em transformação",521, no entanto, esse tempo foi sendo substituídos pelo tempo social abstrato, “equivalente em quantidade ao tempo de trabalho, foi se impondo para cada um e para todos, segundo a lógica da reprodução capitalista da sociedade.”522

Afirma Seabra, que foi durante o século vinte que a vida de bairro teve seu boom. Para a autora,

[...] foi sob os impulsos da industrialização que a vida de bairro em São Paulo se tornou mais ampla, difusa, diversa e mais rica. Como se sabe, porque já foi muito discutido, um dos atributos positivos do mundo do trabalho que ia se estabelecendo com a industrialização foi o de poder reunir aquilo que estava disperso, de redefinir o pré-existente, o supérfluo, o sobrante. Além disso, a vida de bairro, impulsionada pela industrialização em São Paulo, foi levada a um extraordinário sincretismo, por que reuniu matrizes culturais muito diversas. Reuniu aos negros, brancos e índios, estes que estavam na origem da ocupação e do povoamento da região de São Paolo, a imigração estrangeira. ${ }^{523}$

Tomemos esse período ainda como o do tempo lento, das relações vicinais e do vivido, no entanto, com o fenômeno da metropolização e a crescente aceleração e diversificação do tempo observamos a relação poróquia-bairro desestabilizar e entrar em colapso.

A metropolização apresenta-se como um processo do século vinte e teve como conseqüência a metamorfose da cidade em metrópole. ${ }^{524}$ Segundo Seabra, a metropolização “como processo foi a estruturação dos mercados, implicando, de um ponto de vista lógico, produtividade crescente do trabalho e racionalidade técnica do espaço, sob premissas de relações profundamente desiguais." ${ }^{~ 525}$ Desta forma, a cidade e seus bairros só podem ser entendidos enquanto foco circunstancial do processo de urbanização.

Para a autora "a metrópole vai ganhando realidade como síntese de um gigantesco processo mobilizador e concentrador, que produz uma outra espacialidade do urbano. A metrópole se configura como uma síntese contraditória da cidade.”526

\footnotetext{
520 . Ibidem, p.231.

521 . Idem.

522 . Idem.

523. SEABRA, O. C. L., op.cit., 2000, p.12.

${ }^{524}$. SEABRA, O. C. L., op.cit., 2003, p.367-368.

${ }^{525}$. SEABRA, O. C. L., op.cit., 2000, p.12.

${ }^{526}$. Idem.
} 
O processo de urbanização, com a configuração de metrópole, resultou no rompimento definitivo da vida de bairro.

O cotidiano estabelecido pela velocidade do viver na cidade não permitiu mais as trocas que antes predominavam na convivência coletiva e o individualismo passou a prevalecer. Perdeu-se, também, a importância da rua e da praça.

E, longe das antigas tradições que condicionaram as relações sócio-culturais, o Bairro da Penha deixou de se apresentar como espaço do vivido e se transformou definitivamente em apenas mais uma unidade administrativa da metrópole paulistana.

Enfim, ao estudarmos as transformações históricas da Penha, procuramos mostrar que o bairro enquanto categoria socioespacial, que inclui diversas espacialidade/temporalidade/sociabilidades, não está apenas contido na totalidade que é a cidade de São Paulo, como também contém. Portanto, temos aqui a própria história da cidade que se revela a partir do momento em que consideramos a Penha enquanto totalidade que faz parte de uma totalidade maior.

Tal concepção também deve ser vista como um processo em movimento, portanto esperamos que esta dissertação não venha apenas contribuir para o entendimento do processo histórico e espacial da configuração urbana da Penha, mas também proporcionar novas indagações que estimulem mais pesquisas sobre a localidade e a metrópole paulistana. Ainda existem muitas questões não respondidas. 


\section{REFERÊNCIAS BIBLIOGRÁFICAS}

ANDRADE, Margarida Maria de. Bairros Além-Tamanduateí: o imigrante e a fábrica no Brás, Mooca e Belenzinho, Tese de Doutoramento apresentada na Faculdade de Filosofia, Letras e Ciências Humanas da Universidade de São Paulo - Departamento de Geografia, São Paulo, 1991.

ARROYO, Leonardo. Igrejas de São Paulo, Rio de Janeiro: José Olympio, 1954.

ARAUJO FILHO, J.R. de. A população paulistana. In AZEVEDO, Aroldo de, org. A cidade de São Paulo. Estudos de Geografia urbana. São Paulo: Nacional, vol.2, 1958.

AZEVEDO, Edgard A. de. Subúrbios Orientais de São Paulo. Tese de concurso à cadeira de Geografia do Brasil da Faculdade de Filosofia, Ciências e Letras da Universidade de São Paulo. São Paulo, 1945.

Vilas e Cidades do Brasil Colonial. In: Anais do Departamento de Geografia, São Paulo: Associação de Geógrafos Brasileiro, 1956.

A Cidade de São Paulo - Estudos de geografia urbana, Vol. I, II, III e IV. AGB. São Paulo: Cia. Editora Nacional, 1958.

BEM, Silvia Ferreira, Contribuição para estudos das estações ferroviárias paulistas. Tese de Dissertação de Mestrado apresentada à Faculdade de Arquitetura e Urbanismo da Universidade de São Paulo, vol. I, 1998.

BERNARDES, Adriana. A presença do velho e do novo na cidade de São Paulo - o caso das pequenas e médias indústrias não hegemônicas. In: Revista Experimental, n ${ }^{0} 1$, FFLCH - USP. São Paulo, julho de 1996.

BÔA NOVA, Antônio Carlos. Clero e Povo - O Catolicismo da América Latina nos anos 60, São Paulo: CERU e FFLCH/USP, 1981.

BONTEMPI, Silvio. O Bairro da Penha. São Paulo: Prefeitura Municipal de São Paulo / Secretaria de Educação e Cultura, 1968.

BRITO, Mônica Silveira. A participação da iniciativa privada na produção do espaço urbano: São Paulo. 1890-1911. Dissertação de Mestrado. FFLCH-USP. São Paulo, 2000 .

BRUNO, Ernani Silva. Histórias e Tradições da Cidade de São Paulo, Volume I - Arraial de Sertanistas (1554-1828). São Paulo: Editora Hucitec/ Prefeitura do Município de São Paulo - Secretaria Municipal de Cultura, 1984. 
BOSI, Ecléa. Memória,e Sociedade: lembranças de velhos. São Paulo: T.A Queiroz editor, 1979, p.370. apud. RAMOS, A. W. op.cit., 2001, p.161.

Cadernos de História de São Paulo 1 - Os campos do conhecimento e o conhecimento da cidade. Museu Paulista da Universidade de São Paulo. São Paulo, 1992.

CANDIDO, Antonio, Os parceiros do Rio Bonito: estudo sobre o caipira paulista e a transformação dos seus meios de vida. $8^{\mathrm{a}}$ ed., São Paulo: Duas Cidades, 1998.

CARLOS, Ana Fani Alessandri. O lugar no/do Mundo. São Paulo: Editora Hucitec, 1996. A (re)produção do espaço urbano. São Paulo: Edusp, 1994.

CHOAY, Françoise. O Urbanismo - Utopias e Realidades, Uma Antologia. São Paulo: Editora Perspectiva, 1979.

COSTA, Luís C. e MELLO, Leonel I. História do Brasil. São Paulo: Editora Scipione, 1993.

EGYDIO MARTINS, Antonio. São Paulo Antigo - 1554 a 1910. Coleção São Paulo. Obra original de dezembro de 1911. São Paulo: Paz e Terra, 2003, p.383.

DELI, Fernando Rodrigues. A Importância do Povoamento e da Circulação no Processo de Fragmentação do Vale do Aricanduva. Trabalho de Graduação Individual apresentado ao Departamento de Geografia da Faculdade de Filosofia Letras e Ciências da Universidade de São Paulo, São Paulo. 1994.

DONNE, Marcella Delle. Teorias sobre a Cidade - Arte \& Comunicação. Lisboa: Edições 70, 1979.

DUARTE, Cláudio Roberto. Estilhaços da experiência urbana moderna - Dois Bairros na metrópole de São Paulo: Tatuapé e Vila Aymoré. Dissertação de Mestrado, FFLCH, USP - Departamento de Geografia, 2001.

DUARTE, Paulo Araújo. Cartografia Temática. Coleção Didática, Florianópolis: Editora da UFSC, 1991.

FORTI, Reginaldo. Marxismo e Urbanismo Capitalista. São Paulo: Livraria Editora Ciências Humanas, 1979.

FREYRE, Gilberto. Prefácio. In: RODRIGUES FILHO, Mário. O negro no futebol. Rio de Janeiro: Editora Pingetti, 1947.

GEORGE, Pierre. Geografia Urbana. São Paulo: DIFEL, 1983.

GLEZER, Raquel. Chão de Terra: um estudo sobre São Paulo colonial. Tese apresentada ao concurso de Livre Docência em Metodologia da História. Departamento de História/FFLCH/USP. São Paulo, 1992. 
GUIMARÃES, Simone de Jesus. Serviço Social e Igreja Católica no Brasil Pós Ditadura. Tese de doutoramento apresentada à Pontifícia Universidade Católica de São Paulo, na área de Serviço Social, 1998.

LANGENBUCH, Juergen Richard. A Estruturação da Grande São Paulo. Rio de Janeiro, IBGE, 1971.

LANGENBUCH, Juergen Richard. Depoimento. In: Espaço \& Debates, Revista de Estudos Regionais e Urbanos, número 42, Ano XVII, São Paulo, 2001.

LEFEBVRE, Henri. Barrio y vida de barrio. In: De lo rural a lo urbano. Barcelona: Ediciones Península., 1971.

La vida social em la ciudad. In: De lo rural a lo urbano, Barcelona:

Ediciones Península., 1971.

La Pruduction de l'espace. $4^{\circ}$ ed. Paris: Éditions Anthropos, 1986.

1976.

Espacio y Política: el direcho a la ciudad. Barcelona: Ediciones Península,

A Revolução Urbana. Tradução de Sérgio Martins, Belo Horizonte: Editora da UFMG, 1999,

O Direito à Cidade. São Paulo: Editora Moraes, 1991.

LIMA, Rui Cirne. Pequena História Territorial do Brasil- Sesmarias e Terras Devolutas. São Paulo: Arquivo do Estado de São Paulo, 1991.

LINGUITTE, Hedemir. Santuário de Nossa Senhora da Penha. São Paulo, 1989(?).

LOPES, M. B. P. O. Pequena história dos transportes públicos de São Paulo. São Paulo: Museu CMTC dos transportes públicos, $2^{\circ}$ ed., 1985.

LOUREIRO, Maria Amélia Salgado. Origem Histórica dos Cemitérios. São Paulo: Secretaria de Serviços e Obras de São Paulo, 1977.

Manual de Nossa Senhora da Penha. Escolas Profissionais Salesianas, 1936.

MARCÍLIO, Luiza Maria. Crescimento Demográfico e Evolução Agrária Paulista. Tese de Livre-Docência na Disciplina de História Contemporânea do Departamento de História apresentada à Faculdade de Filosofia, Letras e Ciências Humanas da Universidade de São Paulo, São Paulo, 1974.

MARCONDES, J. V. e FREITAS, Osmar. São Paulo, Espírito, Povo e Instituições. São Paulo: Livraria Pioneira Editora, 1968.

MARTIN, André, R. O bairro do Brás e a "deterioração urbana". Dissertação de Mestrado. FFLCH-USP - Departamento de Geografia. São Paulo, 1984. 
MARTIN, Malachi. Os Jesuítas - A Companhia de Jesus e a traição à Igreja Católica. São Paulo: Editora Record, 1979.

MARTINS, José de Souza (org.). Henri Lefebvre e o retorno à dialética. São Paulo: Editora Hucitec, 1996.

O Cativeiro da Terra. 6 a ed., São Paulo: Hucitec, 1996.

Depoimento. In: Espaço \& Debates, Revista de Estudos Regionais e Urbanos, número 42, Ano XVII, São Paulo, 2001

Subúrbio - Vida Cotidiana e História no Subúrbio da Cidade de São Paulo: São Caetano, do fim do império ao Fim da Republica Velha. São Paulo/São Caetano, Hucitec/Prefeitura de São Caetano do Sul, 1992.

MARX, Murillo. Nosso Chão: do Sagrado ao Profano. São Paulo: Edusp, 1989.

Cidade no Brasil terra de quem?. São Paulo: Nobel-Ed. Universidade de São Paulo, 1991.

Cidade no Brasil em que termos?. São Paulo: Studio Nobel, 1999.

Paulo, 1980.

Cidade Brasileira. São Paulo: Melhoramentos-Ed. Universidade de São

MATOS, Odilon Nogueira de. Café e Ferrovias: A evolução ferroviária de São Paulo e o desenvolvimento da cultura cafeeira. $2^{\mathrm{a}}$ ed., São Paulo: Editora Sociologia e Política, 1974.

MELLO NÓBREGA, Humberto de. História do rio Tietê. Belo Horizonte/ São Paulo: Itatiaia/ Edusp, 1981.

MENDES, Renato de S. Os Bairros da Zona Norte e os Bairros Orientais. In: Azevedo, A. (org.). A cidade de São Paulo: (estudos de Geografia Urbana). São Paulo: Cia. Ed. Nacional, 3 vols, 1958.

MONBEIG, Pierre. Aspectos Geográficos do Crescimento da Cidade de São Paulo. In: Boletim Paulista de Geografia. São Paulo, 1954.

O estudo geográfico das cidades. Boletim Geográfico. Ano I, $\mathrm{n}^{\circ}$ 7, Conselho Nacional de Geografia/IBGE, outubro, 1943.

MORAES, Antônio Carlos Robert e COSTA, Wanderley Messias da. A Valorização do Espaço. São Paulo: Hucitec, 1984.

MORAES, José Geraldo Vinci de. As sonoridades paulistanas: A música popular na cidade de São Paulo - final do século XIX ao inicio do século XX. Rio de Janeiro: Funarte, 1997. 
MORSE, Richard M. Formação histórica de São Paulo (de comunidade à metrópole). São Paulo: Difusão Européia do Livro, 1970.

OLIVEIRA, Ariovaldo Umbelino de. A lógica da especulação imobiliária. In: Boletim Paulista de Geografia, n55, nov. ,São Paulo,1978.

OLIVEIRA, Pedro A. Ribeiro de. Religião e Dominação de Classe: gênese, estrutura e função do Catolicismo Romanizado no Brasil. São Paulo: Vozes, 1985.

PENTEADO, Antônio R. Contribuições ao Estudo da Região Suburbana de São Paulo. In: Anais da Associação dos Geógrafos Brasileiros, Vol. IX, tomo I. São Paulo, $1954 / 55$.

1958.

Os Subúrbios de São Paulo e Suas Funções. São Paulo: Editora Nacional,

PETRONE, Pasquale. A cidade de São Paulo no século XX. In: Revista de História. São Paulo, 1955.

PRIORE, Mary Del, Religião e Religiosidade no Brasil colonial. São Paulo: Ed. Ática, $2^{\mathrm{a}}$ ed., 1995.

QUEIROZ, Maria Isaura Pereira de. Bairros rurais paulistas: dinâmica das relações bairro rural-cidade. São Paulo: Livraria Duas Cidades, 1973.

Cultura, sociedade rural, sociedade urbana no Brasil. São Paulo: Editora Universidade de São Paulo, 1978.

RAMOS, Aluísio W. Fragmentação do espaço na cidade de São Paulo: espacialidades diversas do bairro da Água Branca. Dissertação de Mestrado, FFLCH, USP Departamento de Geografia, 2001.

ROLNIK, Raquel. A cidade e a lei: legislação, política urbana e territórios na cidade de São Paulo. São Paulo: Studio Nobel/Fapesp, 1997.

ROSENDAHL, Zeny. Espaço e religião: uma abordagem geográfica. Rio de Janeiro: URJ-NEPEC, 1996.

SAMPAIO, Maria Ruth Amaral de. O papel da iniciativa privada na formação da periferia paulistana. In Espaço \& Debate: A cidade Brasileira, século XX, n³7, São Paulo: NERU, 1994, p.19.

SANTARCANGELO, Maria Candido Vergueiro. Penha de França 1668-1968. São Paulo, 1968 In: CD-ROM. Retratos da Penha. Produzido pelo Memorial Penha de França, org. Francisco Falco, São Paulo, 2004.

SANT'ANA, Nuto. Festas religiosas e profanas. In: Ensaios Paulistas. São Paulo: editora Anhambi S/A, 1958. 
SANTOS, Joaquim Justino Moura de. De freguesias rurais a subúrbio: Inhaúma e Irajá no Município do Rio de Janeiro. Tese de Doutorado em História Social apresentada no Departamento de Filosofia, Letras e Ciências Humanas da Universidade de São Paulo. São Paulo, 1996

SANTOS, Milton. A natureza do Espaço, técnica e tempo - razão e emoção. São Paulo: Editora Hucitec. $3^{\text {a }}$ ed., 1999.

Espaço \& Método. $3^{\mathrm{a}}$ edição, São Paulo: ed. Nobel, 1992.

Manual de Geografia Urbana. São Paulo: Editora Hucitec, 1989.

Sociedad y espacio: la formación social como teoría y como método. In: De la totalidad al lugar.. Barcelona: Aikos-tau, 1996.

As técnicas, o tempo e o espaço geográfico. In: A natureza do espaço. Editora Hucitec. São Paulo, 1999.

SAINT-HILAIRE, Auguste de. Segunda Viagem do Rio de Janeiro a Minas Gerais e a São Paulo (1822). São Paulo: Editora Nacional, 1938.

SEABRA, Odette, C. L. Urbanização: bairro e vida de bairro. Travessia: revista do migrante. São Paulo, publicação do CEM, ano XIII, n.38, set./dez. de 2002.

Urbanização e fragmentação: Cotidiano e vida de bairro na metamorfose da cidade em metrópole, a partir das transformações do bairro do Limão. Tese de livre-docência, FFLCH, USP - Departamento de Geografia, 2003.

SCHMIDT, Afonso. Menino Felipe, Primeira Viagem. São Paulo: Editora Brasiliense Ltda., 1950.

SILVIA, Janice T. São Paulo 1554-1880, discurso ideológico e organização espacial. São Paulo: Editora Moderna, 1984.

SMITH, Roberto. Propriedade da Terra \& Transição: Estudo da Formação da Propriedade Privada da Terra e Transição para o Capitalismo no Brasil. São Paulo: CNPQ/Brasiliense, 1990.

SOUZA, Marcelo J. Lopes de. O Bairro Contemporâneo: ensaio de abordagem política. In: Revista Brasileira de Geografia, nº 51. Rio de Janeiro, abr./jun. de 1989.

TUAN, Yi-fu. Visibilidade: A criação de Lugar. In: Topofilia - Um Estudo de Percepção, Atitudes e Valores do Meio Ambiente. São Paulo: Difel, 1980.

VELHO, Otávio Guilherme (org. e trad.). O Fenômeno Urbano. 2a edição. Rio de Janeiro: Zahar Editores, 1973, p.40.

VILLAÇA, Flávio. Espaço intra-urbano no Brasil. São Paulo: Studio Nobel/FAPESP/Lincoln Institute, 1999. 
DIÁRIO DO COMÉRCIO. Associação Comercial de São Paulo. Disponível em: http://www.dcomercio.com.br/especiais/acsp110anos/ofuturo.htm. Acesso em: 01/05/2006.

\section{Entrevista:}

a) Realizadas pelo pesquisador

Sr. Alípio. São Paulo, junho de 2006.

Sr. Clara. São Paulo, julho de 2006.

Sr. Fábio. São Paulo, março de 2002.

Sr ${ }^{\mathrm{a}}$. Elizabeth. São Paulo, agosto de 2006.

Sr. Luis. São Paulo, julho de 2006.

Sr. Pacha. São Paulo, março de 2002.

b) Outras

Sr. Luís Several Maciel. Entrevista consultada no site do Clube Esportivo da Penha, 1996. Disponível em http://www.cepenha.com.br/ index1.htm. Acesso em 30 junho 2006.

\section{Fontes:}

a) Documentos e manuscritos consultados:

ATAS DA CAMARA DE SÃO PAULO, Departamento de Cultura, Prefeitura Municipal de São Paulo, 1903. Nesta edição foram consultadas as atas referentes aos anos de 1874, 1875.

ATAS DA CAMARA DE SÃO PAULO, Departamento de Cultura, Prefeitura Municipal de São Paulo, 1905. Nesta edição foram consultadas as atas referente ao ano de 1890.

ATAS DA CAMARA DE SÃO PAULO, Departamento de Cultura, Prefeitura Municipal de São Paulo, 1908. Nesta edição foram consultadas as atas referentes aos anos de 1892, 1897.

ATAS DA CAMARA DE SÃO PAULO, Departamento de Cultura, Prefeitura Municipal de São Paulo, 1949. Nesta foram consultadas as atas referentes aos anos de 1852, 1856, 1861, 1862, 1869. 
ATAS DA CAMARA DE SÃO PAULO, Departamento de Cultura, Prefeitura Municipal de São Paulo, 1948. Nesta edição foram consultadas as atas referentes aos anos de 1858 , 1869, 1876, 1877.

CÓDIGO DE POSTURAS DO MUNICÍPIO DE SÃO PAULO DE 06 DE OUTUBRO DE 1886. São Paulo: Departamento de Cultura do Município de São Paulo, 1940.

DOCUMENTOS HISTÓRICOS. Rio de Janeiro: Biblioteca Nacional, 1929.

INVENTÁRIOS E TESTAMENTOS - VOL. XXVI. São Paulo: Publicações do Departamento do Arquivo do Estado, s/d.

JORNAL MENSAGEIRO DE NOSSA SENHORA DA PENHA. Orgão da Parochia da Penha, na 01, Anno I, São Paulo, Janeiro de 1929.

JORNAL MENSAGEIRO DE NOSSA SENHORA DA PENHA. Orgão da Parochia da Penha, nº 04, Anno I, São Paulo, Abril de 1929.

LIVRO TOMBO DA FREGUESIA DE NOSSA SENHORA DA PENHA, Códice 12-1-11, Cúria Metropolitana de São Paulo, aberto em 1918.

LIVRO TOMBO DA FREGUESIA DE NOSSA SENHORA DA PENHA, Códice 8-3-12, Cúria Metropolitana de São Paulo, aberto em 1933.

PASTAS DE DOCUMENTOS DA PAROCHIA DE NOSSA SENHORA DA PENHA. Documentos diversos (cartas, contratos, recortes de jornais, etc.), Cúria Metropolitana de São Paulo.

REGISTRO DE ESCRITURAS, Livro 09, Cúria Metropolitana de São Paulo, Códice 06-0128. Registro de Número 456.

REGISTRO DE ESCRITURAS, Livro 10, Cúria Metropolitana de São Paulo, Códice 06-0129. Registros de Números 524, 549, 563.

REGISTRO DE ESCRITURAS, Livro 11, Cúria Metropolitana de São Paulo, Códice 06-0130. Registro de Números 563, 571, 613.

REGISTRO PAROQUIAL DE TERRAS, Livro 169, Penha de França, registro $\mathrm{n}^{\circ} 18$. Arquivo do Estado de São Paulo, 1855.

REGISTRO PAROQUIAL DE TERRAS, Livro 169, Penha de França, registro $\mathrm{n}^{\circ} 38$. Arquivo do Estado de São Paulo, 1855.

REGISTRO PAROQUIAL DE TERRAS, Livro 169, Penha de França, registro n ${ }^{\circ} 105$. Arquivo do Estado de São Paulo, 1855.

REGISTRO PAROQUIAL DE TERRAS, Livro 169, Penha de França, registro $\mathrm{n}^{\circ} 117$. Arquivo do Estado de São Paulo, 1855. 
REGISTRO DE ESCRITURAS, Livro 04, Cúria Metropolitana de São Paulo, Códice 06-0123. Registros de Números 191, 193, 194, 195, 196, 197, 198, 199, 200, 200A, 200B, 201, 202, 258.

b) Plantas, cartas e mapas:

CARTA DA PENHA DE FRANÇA. Indicações diversas. Organização EMPLASA. Escala $1: 10.000,1981$.

MAPPA TOPOGRÁPHICO DO MUNICIPIO DE SÃO PAULO. Organização: Sr Dr. José Pires do Rio. SARA Brasil S/A. Escala 1:20.000, 1930.

PLANTA DA CIDADE DE SÃO PAULO. Planta geral da Capital. Organização: Gomes Jardim. Escala 1:20.000, 1897.

PLANTA DA CIDADE DE SÃO PAULO. Indicações diversas. Organização Eng. ${ }^{\circ}$ Alexandre M. Cococi e L.F.F. da Costa. Prefeitura Municipal de São Paulo. Escala 1:20.000, 1905.

PLANTA GERAL DA CIDADE DE SÃO PAULO. Indicações de Ruas. Organização Cia. Indl. Import. Lithográfica \& C. Escala 1:30.000, 1907.

PLANTA DA CIDADE DE SÃO PAULO. Diretoria de Obras e Viação da Cidade de São Paulo. Escala 1:20.000, 1916.

PLANTA DA CIDADE DE SÃO PAULO. Diretoria de Obras e Viação da Cidade de São Paulo. Escala 1:20.000, 1918.

PLANTA DA CIDADE DE SÃO PAULO. Repartição de Águas e Esgotos. Organização: Engo José Emiliano Schalc. Escala 1:20.000, 1928/29.

PLANTA DA CIDADE DE SÃO PAULO. Indicações diversas - Bairros. Escala 1:30.000, 1937.

PLANTA GERAL DA CIDADE DE SÃO PAULO. Edição GeoBrasil Patenteada (encadernada). Escala 1:20.000, 1947.

c) CDs Room

RETRATOS DA PENHA, Memorial Penha de França. $3^{a}$ edição, São Paulo, 2004. CD ROM. Todas as imagens digitalizadas utilizadas no trabalho são do mesmo acervo. 
